\title{
Vladimir Nabokov i jego synestezyjny świat
}


揊 
Anna Ginter

\section{Vladimir Nabokov i jego synestezyjny świat}


Anna Ginter - Uniwersytet Łódzki, Wydział Filologiczny, Instytut Rusycystyki Zakład Językoznawstwa, 90-236 Łódź, ul. Pomorska 171/173

\author{
RECENZENT \\ Beata Rycielska \\ REDAKTOR INICJUJĄCY \\ Urszula Dzieciatkowska \\ REDAKTOR WYDAWNICTWA UŁ \\ Bogustaw Pielat \\ SKŁAD I ŁAMANIE \\ Oficyna Wydawnicza Edytor.org \\ Lidia Ciecierska \\ PROJEKT OKŁADKI \\ Studio $7 A$
}

Na okładce wykorzystano zdjęcie: Vladimir Nabokov w 1958 r.

Autor zdjęcia Fred Stein. Zdjęcie uzyskane ze zbiorów PAP/DPA

C Copyright by Uniwersytet Łódzki, Łódź 2015

Wydane przez Wydawnictwo Uniwersytetu Łódzkiego

Wydanie I. W.06926.15.0.M

Ark. wyd. 11,0; ark. druk.15,75

ISBN 978-83-7969-787-8

e-ISBN 978-83-7969-788-5

Wydawnictwo Uniwersytetu Łódzkiego

90-131 Łódź, ul. Lindleya 8

www.wydawnictwo.uni.lodz.pl

e-mail: ksiegarnia@uni.lodz.pl

tel. (42) 6655863 
Sni 



\section{SPIS TREŚCI}

WSTEC .

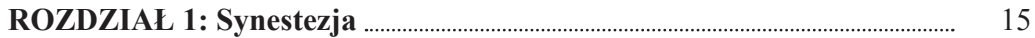

Z historii badań nad synestezją .............................................................................. 15

Definicja synestezji ............................................................................................ 25

Mechanizm i źródła synestezji .................................................................................. 32

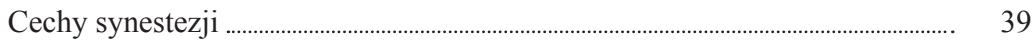

Odmiany synestezji .............................................................................................................. 46

Ordinal linguistic personification ........................................................................... $\quad 55$

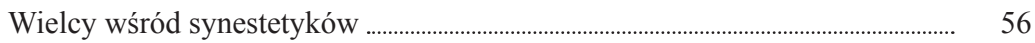

ROZDZIAŁ 2: Synestezja w utworach Nabokova .............................................. 63

Nabokov i zamiłowanie do szczegółu ................................................................ 63

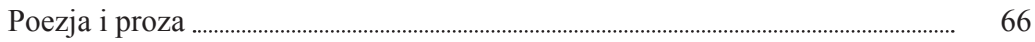

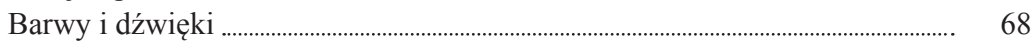

Odmiany Nabokovowskiej synestezji: .................................................................... $\quad 79$

Doznania związane z widzeniem ................................................................. $\quad 79$

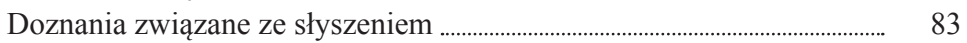

Doznania związane ze smakiem ................................................................. 93

Doznania związane $\mathrm{z}$ dotykiem ............................................................... 94

Doznania związane z zapachem ............................................................ 95

Doznania związane $\mathrm{z}$ temperaturą ........................................................................ 98

Doznania związane $\mathrm{z}$ bólem ........................................................................... 99

Doznania polisensoryczne ............................................................................. 100

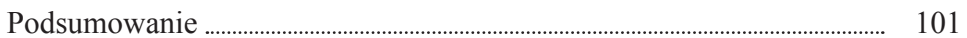

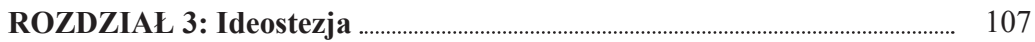

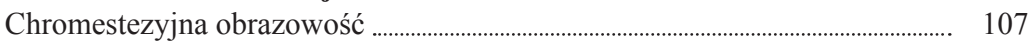

Barwne postrzeganie liter ............................................................................................. 110

Kolorowy alfabet Nabokova ............................................................................... 115

Pochodzenie synestezyjnych barw ............................................................................ 123 


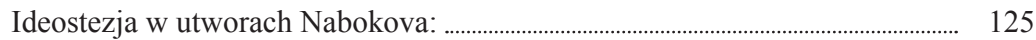

Bohaterowie utworów wobec daru synestezji .................................................... 125

Ideostezyjna symbolika liter ....................................................................................... 128

Kolorowe tony nazw ........................................................................................................... 132

Wielopłaszczyznowość skojarzeń ideostezyjnych ............................................ 138

Ordinal linguistic personification ............................................................................... 140

Podsumowanie .............................................................................................................................. 143

ROZDZIAŁ 4: Metafora synestezyjna …….......................................................... 145

Synestezja jako synteza sztuk ............................................................................................ 145

Synestezja a metafora synestezyjna …………….......................................................... 147

Uniwersalne doświadczenia synestezyjne .............................................................. 149

Synestezja silna i słaba ........................................................................................................ 153

Ogólne tendencje synestezyjne .............................................................................................. 155

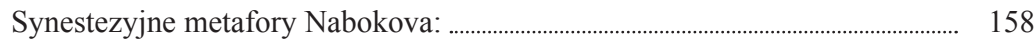

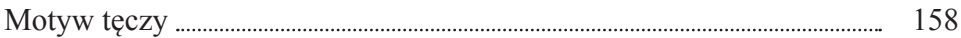

Synestezyjne postrzeganie czasu i przestrzeni ................................................... 165

Nabokovowskie metafory międzymodalne ...................................................... 170

Schemat metafory synestezyjnej ...................................................................... 179

Metafory łączące doznania zmysłowe z niezmysłowymi ............................. 183

Podsumowanie ......................................................................................................................... 210

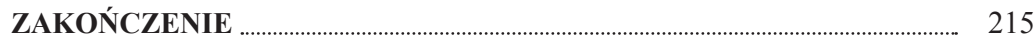

WYKAZ WYKORZYSTANYCH UTWORÓW NABOKOVA _........................... 219

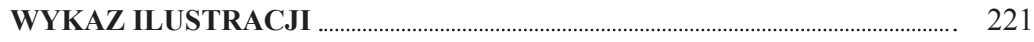

WYKAZ TABEL ........................................................................................................... 223

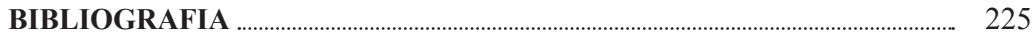

VLADIMIR NABOKOV AND HIS SYNAESTHETIC WORLD (Sum-

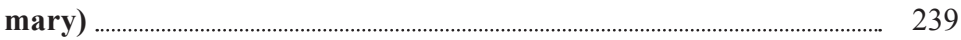

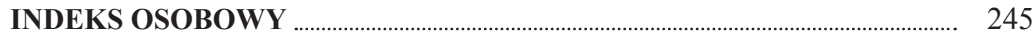

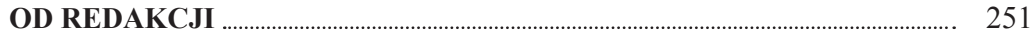




\section{WSTĘP}

Synestezja jest zjawiskiem, które nie jest ograniczone geograficznie, narodowościowo czy rasowo. Pojawia się na każdym kontynencie i odnotowywane jest od najdawniejszych czasów. Dotyczy zarówno kobiet, jak i mężczyzn, mieszkańców metropolii i oddalonych od cywilizacji wiosek. Jest uwarunkowana czynnikami fizjologicznymi i genetycznymi, choć nie bez znaczenia pozostaje aspekt kulturowy i społeczny.

Choć doznania międzysensoryczne nie są zjawiskiem ani nowym, ani szczególnie rzadkim, zainteresowanie ich naturą, różnorodnością i pochodzeniem uległo wzmożonej intensyfikacji dopiero w ostatnich dziesięcioleciach, głównie dzięki rozwojowi nauk psychologicznych i medycznych. Pionierskie na tym gruncie prace neurologów: Richarda Cytowica, Vilayanura S. Ramachandrana, Davida Eaglemana, Stephanie Simon-Dack; psychologów: Lawrence'a Edwarda Marksa, Julii Simner, Edwarda Hubbarda, Carol Mills, Simona Barona-Cohena, Danka Nikolicia, Jamie'ego Warda, Uty Marii Jürgens, Ashoka Jansariego, językoznawcy i antropologa Seana Daya (prezesa American Synesthesia Association), historyka sztuki Simona Shawa-Millera i wielu innych wybitnych badaczy, przedstawiają synestezję w nowym świetle - nie jako zabieg stylistyczny czy konstrukcje świadczące o metaforycznym charakterze ludzkiego myślenia, lecz przede wszystkim jako sposób postrzegania świata wyznaczony przez szczególne predyspozycje umysłowe uwarunkowane procesami na poziomie neuronalnym. Zawarte w nich zostały podstawowe informacje o synestezji, hipotezy związane z jej pochodzeniem, próby klasyfikacji zjawisk synestezyjnych oraz opisu mechanizmów nimi rządzących. Zrozumiałe jest zatem, 
że każde rozważania dotyczące wrażeń międzymodalnych jako elementu stylu należy poprzedzić wyjaśnieniem samego zjawiska we wszystkich możliwych jego aspektach, korzystając z najnowszych rezultatów badań, co zostanie uczynione w pierwszym rozdziale niniejszej książki.

Uzasadnienie wyboru twórczości Vladimira Nabokova ${ }^{1}$ jako materiału badawczego w zakresie zjawisk międzysensorycznych nie wymaga szczególnych argumentów. W każdym chyba opracowaniu dotyczącym synestezji znajdziemy jego nazwisko jako przykład twórcy, który sam określał doświadczane przez siebie wrażenia jako barwne słyszenie. Nie unikał też udzielania szczegółowych informacji na temat doznań doświadczanych pod wpływem bodźców sensorycznych. Powszechnie cytowany jest jego kolorystyczny alfabet rosyjskich i angielskich liter. Jednakże oprócz owych cytatów i krótkich wzmianek, synestezyjne wrażenia Nabokova nie doczekały się zbyt wielu opracowań w odniesieniu do ich natury, mechanizmu i różnorodności. Problem doznań zmysłowych i ich roli w kreacji i interpretacji świata utworów Nabokova został podjęty przez Jürgena Bodensteina w 1977 r. w obszernej publikacji pt. The Excitement of Verbal Adventure: A Study of Vladimir Nabokov's English Prose, obejmującej również takie zagadnienia związane z literacką twórczością pisarza, jak słowotwórstwo, neologizmy, gra słów, instrumentacja dźwiękowa, rytm i ironia. Synestezja została jednak potraktowana dość pobieżnie, bez podziału zaobserwowanych zjawisk o charakterze współodczuwania międzysensorycznego na synestezję właściwą, konceptualną i metafory literackie, co oczywiście wynika ze stanu badań nad synestezją

1 Imię i nazwisko pisarza w całym jego długim życiu zapisywane były w różny sposób. W pierwszym okresie miały oryginalną rosyjską postać Владимир Набоков, której odpowiada polska transkrypcja Władimir Nabokow. Po wyjeździe z Rosji w roku 1919, aż do wyjazdu do Ameryki, zapisywano je jako Vladimir Nabokoff. W Stanach Zjednoczonych pisarz stał się Vladimirem Nabokovem, przyjmując najbardziej znaną postać imienia i nazwiska. W niniejszej monografii zastosowano dwa rodzaje pisowni: Vladimir Nabokov w odniesieniu do pisarza oraz Nabokow w przypadku członków jego rodziny: rodziców, rodzeństwa, dziadków itd. 
w chwili powstawania książki. Przykłady zaś ilustrujące poszczególne zjawiska zaczerpnięte zostały jedynie z angielskich tekstów Nabokova.

W roku 2006 ukazała się praca Vladimir Nabokov. Alphabet in Color, która w ilustracjach Jean Holabird i ze wstępem Briana Boyda prezentuje kolory doświadczane przez autora Lolity pod wpływem fonemów odpowiadających poszczególnym literom. Nie znajdziemy tam jednak informacji o innych ewentualnych doznaniach pisarza. Wcześniej, w roku 1985, wydana została książka Donalda Bartona Johnsona Worlds in Regression. Some Novels of Vladimir Nabokov, która najszerzej z dotychczas opublikowanych prac omawia przykłady Nabokovowskiej synestezji, koncentrując się jednak przede wszystkim na przykładach związanych z doświadczaniem brzmienia lub kształtu liter. Podobnie praca Gavriela Shapiro Setting his myriad faces in his text: Nabokov's authorial presence revisited (1999) podejmuje problem nazw własnych w tekstach Nabokova z uwzględnieniem interpretacji synestezyjnej, na uboczu pozostawiając zagadnienie skojarzeń między wrażeniami czysto zmysłowymi.

Nasuwają się zatem pytania: Czy międzysensoryczne doznania Nabokova związane były tylko z jednym rodzajem synestezji? Czy pisarz znany z bezgranicznej wyobraźni, mistrzostwa w posługiwaniu się kolorem i ogromnej wrażliwości na wszelkie doznania zmysłowe nie przejawiał predyspozycji do kojarzenia wrażeń sensorycznych na niskim poziomie bodźców, bez odwoływania się do czynników semantycznych? I co z tym związane - w jakim stopniu ów aspekt znaczeniowy wyznaczał jego synestezyjne doświadczanie świata? Czy wszystkie konstrukcje łączące informacje o różnych odczuciach zmysłowych można określić jako synestezje? A wreszcie, czy pisarstwo Nabokova może pomóc określić różnorodność synestezyjnych wrażeń doświadczanych przez niego. Mówiąc inaczej, na ile teksty pisarza, a nie tylko jego słowa wypowiadane w wywiadach bądź autobiografiach, poświadczają niezwykły dar i ponadprzeciętne predyspozycje do spostrzegania i łączenia doznań zmysłowych? 
Odpowiedź na wszystkie te pytania jest celem rozważań podjętych w kolejnych rozdziałach niniejszej książki.

Materiał badawczy zaczerpnięty został głównie z publikacji Nabokova. Wskazane konstrukcje o charakterze synestezyjnym pochodzą z trzynastu dłuższych tekstów prozatorskich (powieści, autobiografie, opowieść) i ponad czterdziestu opowiadań napisanych w języku rosyjskim lub angielskim w różnych etapach jego twórczego życia. W odtworzeniu faktów z życia pisarza, wydarzeń wyznaczających jego twórczą drogę i jego program estetyczny pomocne okazały się przede wszystkim prace Briana Boyda, Stacy Schiff i Leszka Engelkinga. Jeśli zaś chodzi o poglądy pisarza na twórczość, sztukę, percepcję świata, to głos oddany został przede wszystkim samemu Nabokovowi, który nie tylko we wspomnieniach i wywiadach, ale też w prozie literackiej przekazywał swój punkt widzenia. Czołowe miejsce pod tym względem zajmuje powieść Dar, która uważana jest za polemikę literacką².

Zgromadzone przykłady pozwoliły na przybliżenie charakteru Nabokovowskiej synestezji w trzech jej aspektach. Po pierwsze, są to skojarzenia łączące doznania pochodzące z różnych zmysłów w ich licznych, najbardziej różnorodnych kombinacjach (rozdział 2). Po drugie, charakterystyczna dla Nabokova synestezja grafem-kolor pojawia się wśród szeregu innych przykładów ideostezyjnych, które łączą czynnik sensoryczny z semantycznym (rozdział 3). Po trzecie, do rozważań włączona została ogromna

2 Jedna $\mathrm{z}$ warstw powieści (obok warstw obejmujących partie poświęcone codziennemu życiu bohatera i jego działalności artystycznej) przedstawia poglądy głównego bohatera (Fiodora Konstantynowicza) na literaturę, bliskie poglądom autora. Częścią tej warstwy jest też biografia Nikołaja Gawriłowicza Czernyszewskiego (1828-1889), rosyjskiego publicysty, powieściopisarza i działacza politycznego. Biografia ta jest polemiką z przekonaniami Fiodora Konstantinowicza. Ścieranie się tych dwóch stanowisk służy przedstawieniu koncepcji estetycznej Nabokova. - S. Karlinsky, Nabokov and Chekhov: The Lesser Russian Tradition, [w:] Nabokov: Criticism, Reminiscences, Translarions, and Tributes, eds A. Appel, Jr., C. Newman, New York 1979, s. 15. Podaję za: L. Engelking, Posłowie, [w:] V. Nabokov, Dar, przeł. E. Siemaszkiewicz, posł. L. Engelking, Warszawskie Wydawnictwo Literackie MUZA SA, Warszawa 2003, s. 468. 
liczba skojarzeń metaforycznych nawiązujących do wrażeń sensorycznych, choć nie spełniają one warunków stawianych synestezji w rozumieniu zjawiska o podłożu neuronalnym (rozdział 4). Ich konwencjonalny lub niekonwencjonalny charakter jest ściśle związany z darem pisarza, a interpretacja poszczególnych konstrukcji pokazuje bogactwo jego możliwości twórczych.

Niezwykła umiejętność obserwacji świata i precyzyjnego nazywania jego barw traktowana jest przez badaczy jako cecha charakterystyczna dla synestezyjnego odbioru bodźców. Bogactwo kolorów i ich odcieni widoczne jest w każdym utworze Nabokova, bez względu na jego wielkość i formę. $Z$ uwagi jednak na dużą objętość materiału związanego z barwami w tekstach Nabokova i ich semantyką, temat ten zostanie podjęty w oddzielnej monografii.

Rodzaj analizowanego materiału, który w znaczącej części obejmuje wyrażenia odwołujące się do niedosłowności, wyznaczył interpretacyjny charakter jego prezentacji. Niemal każdy z przedstawionych przypadków można bowiem uznać za przykład specjalnego, celowego użycia, które ma do odegrania ściśle zaplanowaną przez autora rolę. 



\section{SYNESTEZJA}

\section{Z historii badań nad synestezją}

Od najdawniejszych czasów poznawaniu świata towarzyszyły skojarzenia międzysensoryczne. Zjawisko synestezji dostrzec można już w mitach o stworzeniu świata, w świecie starożytnych kultur Mezopotamii, Babilonii, Egiptu, Grecji, Chin, Persji ${ }^{1}$. Jest ono obecne również $\mathrm{w}$ teoriach pitagorejskich, arytmetycznych podstawach muzycznych współbrzmień czy w pismach medycznych ${ }^{2}$. Natomiast najstarsza wzmianka dotycząca zjawiska synestezji jako szczególnej zdolności postrzegania świata pochodzi z roku 1690. Wówczas to ukazały się Rozważania dotyczace rozumu ludzkiego Johna Locke'a, w których opisany został przypadek skojarzenia międzyzmysłowego:

1 Por: J. Jewanski, What is the color of the tone?, „Leonardo” 1999, vol. 32, No 3, s. 227-228; M. Senderecka, Synestezja - od psychofizjologicznych badań do filozoficznych implikacji, [w:] S. Wszołek, R. Janusz (red.), Wyzwania racjonalności, Wydawnictwo WAM, Kraków 2006, wersja on-line: www.kognitywistyka. upjp2.edu.pl/resources/artykuly/sender1.pdf [dostęp: 20.08.2013], s. 260. Por. też: C. Sachs, Muzyka w świecie starożytnym, przeł. Z. Chechlińska, PWM, Warszawa 1988, s. 10-16.

2 Patrz: J. James, Muzyka sfer. O muzyce, nauce i naturalnym porządku wszechświata, przeł. M. Godyń, Wyd. Znak, Kraków 1996, s. 9-23. 
Pewien niewidomy, ciekawy świata, łamał sobie głowę, rozmyślając o rzeczach widzialnych, $[\ldots]$ chełpił się on pewnego razu, że teraz już rozumie, co znaczy 'szkarłat'. A gdy przyjaciel zapytał go, co to jest szkarłat, niewidomy odrzekł, że szkarłat jest podobny do dźwięku trąby’.

Na przykład ten powołuje się Leibnitz w Nowych rozważaniach dotyczacych rozumu ludzkiego (1704), gdy pisze o definicjach nominalnych idei prostych, do których zalicza doznania zmysłowe:

Zgadzamy się więc, że nasze idee proste nie mogą mieć definicji nominalnych, tak jak nie moglibyśmy znać smaku ananasa na podstawie relacji podróżników, chyba żebyśmy mogli doznawać smaku rzeczy za pomocą uszu, tak jak Sancho Pansa zdolny był widzieć Dulcyneę na podstawie tego, co słyszał, albo jak ów ślepiec, który nasłuchawszy się o świetności szkarłatu sądził, że jest on podobny do głosu trąby ${ }^{4}$.

I Lock, i Leibnitz odnoszą się do relacji o tego rodzaju doznaniach z nieskrywanym sceptycyzmem. Obydwaj uważają, że ideę prostą barwy może wzbudzić tylko sama barwa, a ideę prostą dźwięku - tylko sam dźwięk ${ }^{5}$. Jak twierdzi Leibnitz,

Jest rzeczą niemożliwą, ażeby jedna i ta sama rzecz była i nie była równocześnie, to, co białe, nie jest czerwone; kwadrat nie jest kołem, barwa żółta nie jest słodyczą. [...] Każde zdanie złożone z dwóch różnych idei, z których jedna jest zaprzeczeniem drugiej, np., że kwadrat nie jest kołem albo że być żółtym to nie to samo co być słodkim, będzie także z pewnością przyjęte jako niewątpliwe, z chwilą gdy się zrozumie terminy i ogólną zasadę, że jest rzecza niemożliwa, ażeby jedna i ta sama rzecz byta i nie byta równocześnie ${ }^{6}$.

Możliwość połączenia wrażeń wzrokowych i słuchowych stała się przedmiotem rozważań Izaaka Newtona. W swoim dziele zaty-

3 J. Locke, Rozważania dotyczące rozumu ludzkiego, przeł. B. Gawęcki, t. II, PWN, Warszawa 1955, s. 44.

${ }^{4}$ G. W. Leibnitz, Nowe rozważania dotyczace rozumu ludzkiego, przeł. I. Dąmbska, wstęp L. Kołakowskiego, t. II, PWN, Warszawa 1955, s. 45-46.

5 Por.: M. Senderecka, Synestezja..., s. 260-261.

6 G. W. Leibnitz, Nowe rozważania..., s. 61-62. 
tułowanym Optyka (1704), zawierającym wyniki eksperymentów z rozszczepianiem światła za pomocą pryzmatu, zwrócił on uwagę na podobieństwo między barwami składającymi się na widmo światła białego i dźwiękami skali muzycznej.

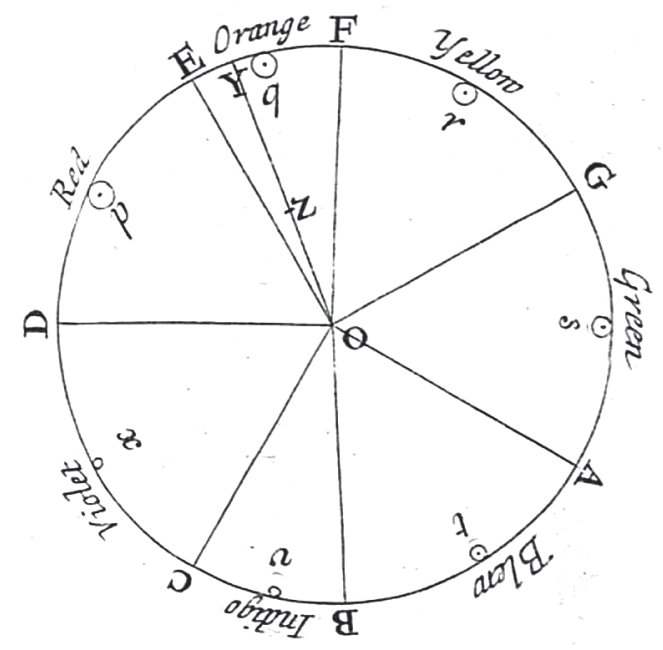

Ilustracja 1. Tarcza barw i dźwięków według Izaaka Newtona

I. Newton, Opticks or A Treatise of the Reflections, Refractions, Inflections, and Colours of Light, Dover Publication, Inc., New York 1952, book 1, part II, s. 155

Źródło grafiki: http://en.wikipedia.org/wiki/Visible_spectrum\#mediaviewer/

File:Newton\%27s_color_circle.png [dostęp: 15.10.2014]

Jak zauważył Newton, poszczególne barwy spektrum odpowiadają naturalnym dźwiękom muzyki, co można przedstawić w sposób graficzny. W opracowanym przez uczonego schemacie spektrum barw od czerwonej do fioletowej zostało podzielone dźwiękami muzyki, zaczynając od D. Okrąg zamyka pełną oktawę, a kolejne dźwięki tworzą gamę d-moll. Każdy wyodrębniony segment odpowiada określonej barwie - począwszy od czerwonej, 
poprzez pomarańczową, żółtą, zieloną, niebieską, indygo, a skończywszy na fioletowej ${ }^{7}$.

Spostrzeżenia Newtona wywarły znaczący wpływ na dalszy rozwój myśli badawczej, również w zakresie synestezji. Athanasius Kircher (1601-1680), niemiecki teoretyk muzyki, znany jest jako twórca teorii przeprowadzającej analogię między skalą barw i dźwięków. Z kolei francuski jezuita Louis Bertrand Castel (16881757), matematyk i fizyk, zadziwił świat tworem audiowizualnym

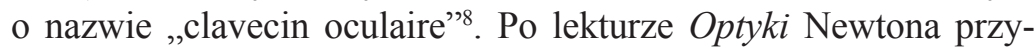
porządkował on kolory dźwiękom i około roku 1730 zbudował „optyczny klawesyn”, który tym różnił się od zwykłego instrumentu, że nad klawiaturą miał skrzynię z sześćdziesięcioma małymi okienkami opatrzonymi zasłonkami, rozsuwającymi się po naciśnięciu odpowiedniego klawisza. Za każdą zasłonką znajdowała się tafla pokolorowanego szkła, której barwa była dobrana zgodnie z wcześniejszymi przemyśleniami. Pokazy z wykorzystaniem „optycznego klawesynu" przyciągały uwagę opinii publicznej. Na jednym z nich obecny był niemiecki kompozytor Georg Philipp Telemann, który napisał kilka utworów przeznaczonych na ten właśnie instrument.

W roku 1754 Castel próbował udoskonalić swój wynalazek, wprowadzając do niego 500 świec i lustra odbijające ich światło, by efekty były widoczne dla większego grona publiczności. Pojawiły się jednak problemy związane z zapachem i wzrostem temperatury w pomieszczeniu, w którym paliło się tak wiele świec. Ograniczenia techniczne związane też były z plątaniem się sznurków, które łączyły zasłonki z klawiszami ${ }^{9}$. W konsekwencji, wbrew przewidywaniom

7 Patrz: I. Newton, Opticks or A Treatise of the Reflections, Refractions, Inflections, and Colours of Light, Dover Publication, Inc., New York 1952, book 1, part II, s. 155.

${ }^{8}$ K. Stępień-Kutera, Bieguny manieryzmu - muzyczność $i$ retoryka, „Res Facta Nova" 2007, nr 9 (18), s. 21, wersja on-line: http://www.resfactanova.pl/ pliki/archiwum/numer_18/RFN18\%20Stepien-Kutera\%20-\%20Bieguny\%20manieryzmu.pdf [dostęp: 21.01.2015].

9 Patrz: W. Moritz, The Dream of Color Music, and Machines That Made it Possible, „Animation World Magazine”, April 1997, Issue 2.1, http://www.awn. 
Castela, że w przyszłości w każdym domu Paryża będzie jego instrument, „optyczne organy” nie przeżyły swego twórcy.

Wraz z rozwojem nauki ,organy świetlne” przechodziły kolejne metamorfozy związane $\mathrm{z}$ wynalezieniem lamp gazowych, a później elektryczności. Zasada ich działania i forma instrumentu były jednak podobne. Dopiero wiek dwudziesty przyniósł nowe idee i wzrost zainteresowania zjawiskiem synestezji. Opisy doznań o charakterze synestezyjnym zaczęły się pojawiać w odniesieniu do ludzi sztuki: kompozytorów, malarzy, pisarzy i poetów. Przykładem jest Aleksander Nikołajewicz Skriabin (1872-1915), rosyjski pianista i kompozytor, który napisał symfonię na orkiestrę $\mathrm{z}$ fortepianem i chór, zatytułowaną Prometeusz: Poemat ognia (1910). Muzyce towarzyszyły kolorowe światła uruchamiane przez fortepian świetlny, w którym każdemu klawiszowi przyporządkowany był określony kolor:

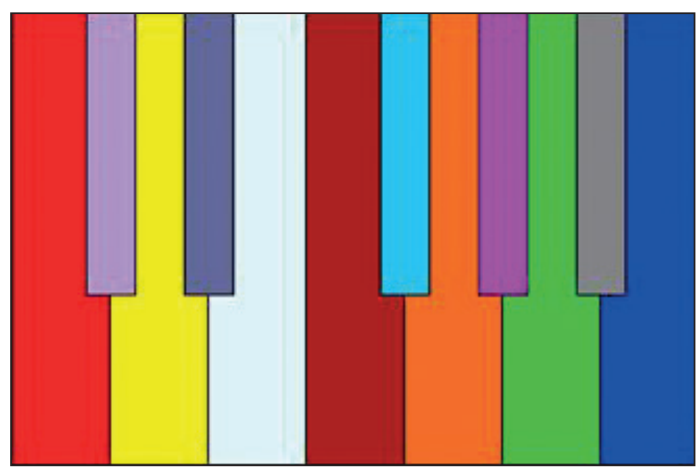

Ilustracja 2. Klawiatura Skriabina

Tone-to-colour mapping of Scriabin's Clavier à lumières

Źródło grafiki: http://commons.wikimedia.org/wiki/File:Scriabin_keyboard.png [dostęp: 26.01.2015]

com/mag/issue2.1/articles/moritz2.1.html [dostęp: 21.01.2015]; oraz P. Nierobisz, Interaktywne projekcje $i$ wizualizacje (VJing) w kontekście filmowym, 2012, s. 18, http://www.visuals.pl/interaktywneProjekcje.pdf [dostęp: 21.01.2015]. 
Skriabin przez wiele lat uznawany był za synestetyka ze zdolnością barwnego słyszenia. Jak jednak wykazały badania dotyczące jego talentu, źródeł jego skojarzeń barw z dźwiękami upatrywać należy w teozofii. Pod jej wpływem Skriabin dzielił tonacje na „duchowe” (np. Fis-dur) i ,ziemskie”, „,materialne” (np. C-dur, F-dur). W ten sposób określał też kolory, np.: czerwony - kolor Abaddonu (szeolu), niebieski i fioletowy - barwy „duchowe”. Zestawienie asocjacji barw z asocjacjami dźwięków pozwoliło mu wyłonić pośrednie skojarzenia: tonacje $\mathrm{C}$-dur i F-dur są czerwone, natomiast Fis-dur - niebieskie ${ }^{10}$. Co więcej, Skriabin wierzył, że jego korelacje między kolorami i dźwiękami mają charakter uniwersalny, a nie indywidualny, jak to dzieje się $\mathrm{w}$ synestezji ${ }^{11}$. Już te argumenty przemawiają za tym, że mamy tu do czynienia nie z przypadkiem doznań międzyzmysłowych, lecz prawdopodobnie z syntezą sztuk w celu wzmocnienia sugestywności muzyki.

Pierwsze wzmianki dotyczące udokumentowanego przypadku doświadczania kolorów muzyki i prostych sekwencji (cyfr, dni, liter) ukazały się w medycznej pracy Georga Tobiasa Ludwiga Sachsa w roku 1812. Od strony empirycznej po raz pierwszy zagadnienie synestezji zostało podjęte przez sir Francisa Galtona. W roku 1880 w czasopiśmie „Nature” ukazał się artykuł jego autorstwa, w którym stwierdzał, że synestezja jest przekazywana z pokolenia na pokolenie, a doznawane przez synestetyków wrażenia międzymodalne mają charakter indywidualny, co potwierdzają liczne podane w tekście przykłady ${ }^{12}$.

10 B. Galeyev, I. Vanechkina, Was Scriabin a Synaesthete?, „Leonardo” 2001, vol. 34, No 4, s. 358, wersja on-line: The MIT Press: http://monoskop.org/ images/f/fa/Galeyev,_B._M.\%3B_Vanechkina,_I._L._\%282001\%29_-_Was Scriabin_a_Synesthete.pdf [dostęp: 25.01.2015].

11 Patrz: S. A. Day, What synaesthesia is (and is not), [w:] P. McKevitt, S. Ó. Nualláin, C. Mulvihill (eds), Language, Vision and Music, John Benjamins B.V., Amsterdam-Philadelphia 2002, s. 176.

12 F. Galton, Visualised Numerals, „Nature”, 15 January 1880, s. 254-255, 494-495; wersja on-line: http://galton.org/essays/1880-1889/galton-1880-nature-visualised-numerals.pdf [dostęp: 3.02.2015]. 
W ostatnich dziesięcioleciach zaobserwować można wzrost zainteresowania zjawiskiem synestezji, ujmowanym z perspektyw różnych dziedzin nauki. Ze względu jednak na fizjologiczne i genetyczne jej podstawy, badania prowadzone są przede wszystkich w zakresie psychologii i medycyny. Ośrodkami zainteresowanymi jak najdokładniejszym poznaniem synestezji są m.in. Amerykańskie Towarzystwo Medyczne (American Medical Association) oraz Amerykańskie Towarzystwo Psychologiczne (American Psychological Association). Powstało nawet Amerykańskie Towarzystwo Synestezyjne (American Synesthesia Association), zgodnie ze swą nazwą całkowicie zaangażowane w badania nad synestezją i rozpropagowanie wiedzy na temat tego fenomenu.

Dziś problematyka synestezyjnej integracji wielozmysłowej pojawia się też w kontekście przestrzeni cybernetycznej. Badania nad synestezją prowadzone są w kierunku głębszego zrozumienia samego zjawiska oraz wykorzystania wcześniejszych rezultatów z jednoczesnym zastosowaniem osiągnięć IT. Przykładem w tym zakresie jest przypadek Neila Harbissona, który łączy synestezyjny odbiór wrażeń i wykorzystanie w tym zakresie najnowszych technologii. W świecie mediów określany jest on jako człowiek, który słyszy kolory ${ }^{13}$.

Neil Harbisson urodził się z rzadką wadą wzroku - achromatopsją (niezdolność widzenia koloru), co oznacza, że nie widzi kolorów, a jego świat jest czarno-biały. Ponadprzeciętnie za to rozwinął się inny jego zmysł - słuch. Na studiach muzycznych nasunął mu się pomysł, że to właśnie muzykę może wykorzystać do percepcji barw, które są istotnym elementem w komunikacji z ludźmi i w postrzeganiu świata. W tym czasie zapoznał się z tezami mówiącymi o podobieństwie tych dwóch zmysłów, tzn. wzroku i słuchu, i postanowił przenieść teorię do rzeczywistości. Oprócz zajęć z muzyki, uczęszczał na wykłady z cybernetyki, na których poznał wiele teorii łączących kolory z dźwiękami, np. wspomnianą wcześniej teorię

13 Patrz materiał audiowizualny: Neil Harbisson - człowiek, który słyszy kolory, http://vumag.pl/wywiady/neil-harbisson-czlowiek-ktory-slyszy-kolory,64143.html [dostęp: 27.10.2014]. 
Newtona, a także ludzi zainteresowanych podobną problematyką, m.in. Adama Montandona - duńskiego naukowca, specjalizującego się w badaniach nad możliwościami urządzeń cyfrowych. Wraz z kilkoma innymi badaczami Harbisson i Montandon utworzyli zespół, stawiając sobie za cel opracowanie takiego urządzenia, które będzie przekazywać barwy za pomocą dźwięków ${ }^{14}$.

Neil Harbisson ma wszczepione niezależne narzędzie, które pozwala mu rozróżniać kolory. Urządzenie na jego głowie wychwytuje wibracje wytwarzane przez kolory. Wibracje te wywołują drgania w jego kościach, które z kolei stają się dźwiękami. Specjalny czujnik nieprzerwanie wysyła informacje o otaczających barwach w formie dźwięków, które Harbisson słyszy w głowie. Co ciekawe jednak, są to dźwięki pochodzące tylko od barw chromatycznych. Czerń, biel i szarość nie wytwarzają bowiem wibracji. Każda barwa i jej odcień (Harbisson rozróżnia ich ponad 360) odpowiada innemu dźwiękowi. Skalę barw i odpowiadających im dźwięków, odbieranych przez Harbissona, zilustrowano za pomocą schematu przypominającego tarczę Newtona (il. 3).

Jak się okazuje, to swoiste przetwarzanie kolorów na dźwięki pozwala Harbissonowi widzieć kolory podczas słuchania muzyki. Swoje wrażenia opisuje w wywiadzie z Aleksandrą Lipczak:

Mozart jest żółty. Beethoven fioletowy i niebieski. Baby Justina Biebera to sam róż. Ale odkąd słyszę kolory, muzyka klasyczna wydaje mi się bardzo prosta. To 12 kolorów, które wciąż się powtarzają. Wolę słuchać mikrotonów, muzyki elektronicznej. Albo fałszowania! Kiedy w szkole na koniec roku występują dzieci, to jest to lepsze przeżycie kolorystyczne niż występ profesjonalnej orkiestry. Lubię też nienastrojone instrumenty. Przyjemnie ich słuchać, bo nagle może pojawić się odcień turkusu, którego wcześniej nie znałem ${ }^{15}$.

14 Źródło informacji o Neilu Harbissonie: Neil Harbisson - człowiek, który styszy kolory..., profil Neila Harbissona, https://www.facebook.com/neilharbisson/info [dostęp: 28.10.2014], wywiad z N. Harbissonem - A. Lipczak, Czerwień gra między f a fis, „Gazeta Wyborcza”, 25.04.2013, wersja on-line: http://wyborcza.pl/piatekekstra/1,132083,13804847,Czerwien_gra_miedzy_f_a_fis.html [dostęp: 12.11.2014].

15 Wywiad z N. Harbissonem: A. Lipczak, Czerwień gra między f a fis... 


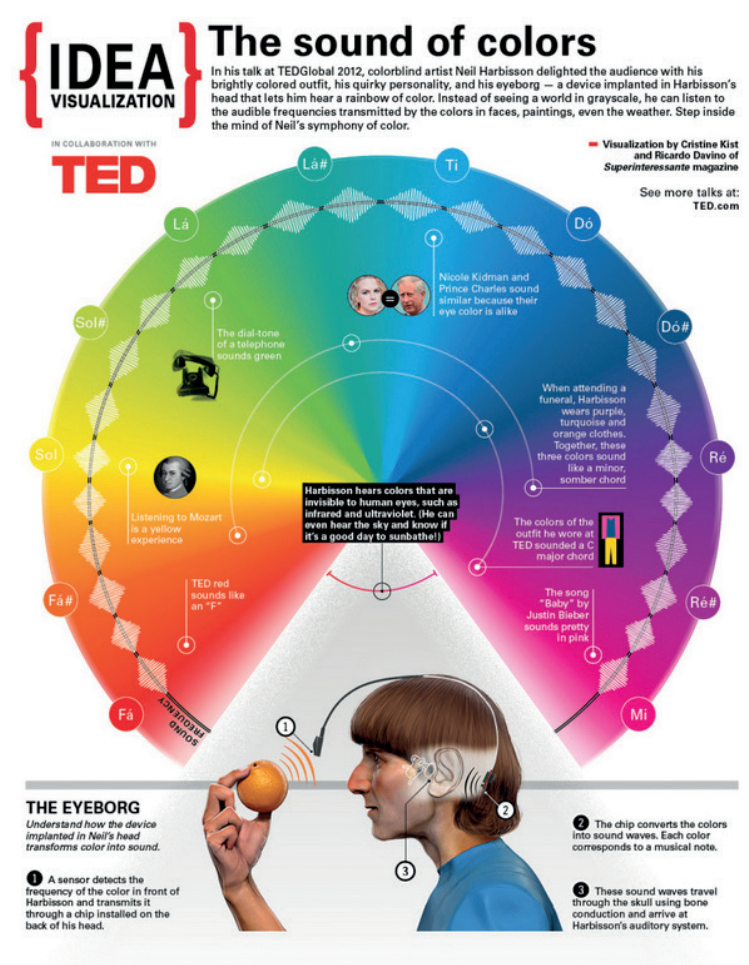

Ilustracja 3. Skala barw i dźwięków Neila Harbissona autorzy grafiki: C. Kist, R. Davino

Źródło grafiki: http://ideas.ted.com/tag/neil-harbisson [dostęp: 12.11.2014]

Dzięki elektronicznemu oku Harbisson maluje muzykę i gra kolory, które są dla niego nutami. Jego prace artystyczne, oparte na transponowaniu barw na dźwięki i dźwięków na barwy, są niewidoczne dla niego i nieme dla widza.

Transponowanie dźwięków na barwy rozpoczyna umieszczeniem pierwszej nuty utworu w centralnym punkcie płótna, przy czym kształt koloru uwarunkowany jest kształtem płótna. Następnie maluje nutę po nucie, aż całe płótno zostanie pokryte dźwiękami danego utworu. 


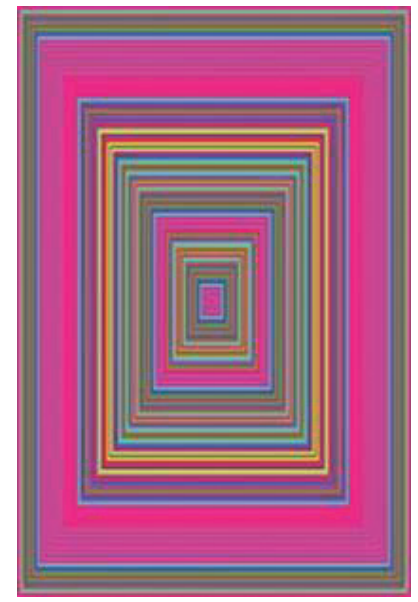

Ilustracja 4. Ludwig van Beethoven, Dla Elizy Przykład dzieła Neila Harbissona Art and Technology

Źródło: „International Herald Tribune”, November 27, 2013, wersja on-line: http://www.iht.com/2013/11/27/art-and-technology [dostęp: 12.11.2014]

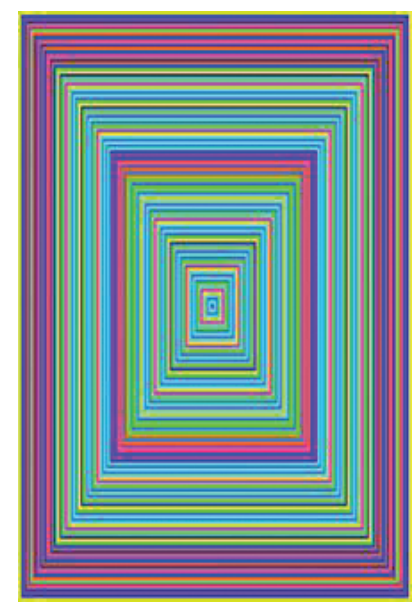

Ilustracja 5. Igor Strawiński, Święto wiosny. Przykład dzieła Neila Harbissona Źródło: Neil Harbisson, Wikipedia: http://en.wikipedia.org/wiki/Neil_Harbisson [dostęp: 12.11.2014] 
Należy też podkreślić to, o czym Neil Harbisson powiedział w wywiadzie, a co stanowi ważną informację ze względu na istotę zjawiska synestezji: po wszczepieniu urządzenia zaczął śnić w kolorach: choć kolor nie jest dla niego czymś wizualnym, gdy śni mu się, że patrzy w niebo, wyraźnie słyszy dźwięk cis. To oznacza, że nie tylko mechanizm przymocowany do głowy, ale po pewnym czasie sam jego mózg zaczął wytwarzać dźwięki kolorów. Jak zauważa Harbisson, barwy można postrzegać za pośrednictwem wszystkich innych zmysłów: sensor można wszczepić w dłoń i będzie wówczas odbierał wibracje kolorów poprzez dotyk; można także wąchać kolory, czuć ich smak. W jego przypadku wybór dźwięków muzyki podyktowany był jego muzycznymi uzdolnieniami i wykształceniem.

\section{Definicja synestezji}

Zasadnicze znaczenie dla każdego rodzaju badań ma sformułowanie definicji i właściwości synestezji w takim stopniu, by można było ponad wszelką wątpliwość rozpoznać i poddać kategoryzacji każdy jej przypadek i przejaw jej wystąpienia. Ustalenie takiej definicji przysparza jednak wielu trudności. Jak się bowiem okazuje, wyniki obserwacji i badań przypadków synestezji nie pozwalają na jednoznaczne i ostateczne jej określenie. Do roku 2009 zaobserwowano ponad 60 różnych manifestacji zjawiska synestezji, z których każda wyróżniała się swoim własnym profilem bodźców i rezultatów doświadczanych wrażeń. Synestezja może zostać wywołana przez tak różnorodne bodźce, jak smak w ustach, wyobrażenie znaczenia słów, muzyka, dotyk, wywołując z kolei tak różnorodne doznania, jak kształty, dźwięki, kolory, smaki, zapachy, uczucie dotyku. Tak szeroki wachlarz bodźców i reakcji utrudnia, a być może nawet uniemożliwia uogólnienie właściwości zjawiska w taki sposób, by w definicji zawrzeć cechy każdej z jego odmian ${ }^{16}$.

16 Por.: J. Simner, Defining synaesthesia, „British Journal of Psychology” 2012, vol. 103, wersja on-line http://www.daysyn.com/Simner2012.pdf [dostęp: 8.07.2013], s. 2. 
Co więcej, opisane zjawiska zdają się przeczyć niektórym dotychczasowym ustaleniom.

Synestezja bywa definiowana: 1) w literaturze jako środek stylistyczny polegający na zestawieniu lub nałożeniu kilku wrażeń zmysłowych i odniesieniu ich do tego samego obiektu ${ }^{17}$; 2) jako występowanie wrażeń zmysłowych towarzyszących przy bodźcu działającym na jeden tylko zmys ${ }^{18}$; 3) w psychologii jako jedność wrażeń: gdy jednozmysłowy bodziec wywołuje jednoczesne wrażenie w co najmniej dwóch modalnościach zmysłowych ${ }^{19}$. Biorąc pod uwagę fakt, że rozważany w niniejszej książce przypadek dotyczy Nabokova - pisarza, który podobnie jak jego matka, żona i syn, synestezji doświadczał w codziennych zmysłowych doznaniach, bliżej powinniśmy się przyjrzeć rezultatom badań w zakresie psychologicznych i medycznych uwarunkowań zjawiska postrzegania międzyzmysłowego. Ich omówienie posłużyć ma za punkt wyjścia obserwacji literackich odniesień Nabokovowskiej synestezji.

W swoich wyjaśnieniach i opisach dotyczących zjawiska synestezji współcześni psycholodzy zwykle zgodnie podają te same następujące informacje:

1) Zaledwie niewielki procent populacji doznaje nadzwyczajnych wrażeń barw, smaków, kształtów, dźwięków itd., które pojawiają się podczas wykonywania codziennych czynności, takich jak czytanie, pisanie, słuchanie muzyki, spożywanie posiłków.

2) Istnieje wiele odmian synestezji: synestetycy mogą na przykład widzieć kolory, gdy słyszą dźwięki muzyki bądź odczuwać smak w ustach w czasie czytania lub mówienia. Przy czym podkreślić należy, że wrażenia te są wyraźnie doświadczane, co oznacza, że synestetycy są w pełni świadomi posiadanych zdolności lub, jak to określił Nabokov - posiadanego daru.

17 Patrz m.in.: C. H. Holman, A Handbook to Literature, Indianapolis 1976, s. 522; N. Frye, S. Baker, G. Perkins, The Harper Handbook to Literature, New York 1985, s. 454.

18 Patrz: M. Szymczak, Słownik języka polskiego, t. III, PWN, Warszawa 1983.

19 Patrz: M. Senderecka, Synestezja..., s. 260; A. Rogowska, Związki synestezji z muzyka, „Muzyka” 2002, nr 1, s. 85. 
3) Synestezyjne wrażenia uzupełniają, ale nie zastępują zwykłych, typowych dla większości ludzi modalnych percepcji. A zatem synestetycy, którzy widzą kolory w czasie odbioru dźwięków muzyki, doświadczają tych barw w ciągu zwykłych codziennych wrażeń słuchowych, jakie są udziałem każdej przeciętnej osoby.

Historia synestezji obfituje w twierdzenia, które opisują to zjawisko jako merging of the senses lub jako pewnego rodzaju crosssensory experience ${ }^{20}$, w którym bodziec percepcyjny uruchamia niezwykłe percepcyjne doświadczenia. Tak określona synestezja zdaje się potwierdzać swoją nazwę: syn- - łączyć, i aesthesia - wrażenie, doznanie.

Takiemu sformułowaniu definicji przeciwstawia własne obserwacje Julia Simner, która w swojej pracy naukowej stara się zbadać i opisać istotę synestezji z punktu widzenia psychologii behawioralnej i neuronauki. W artykule Defining synaesthesia (2012) omawia szereg przypadków, które dowodzą, że opisanie synestezji w terminach czysto zmysłowych stanowi zaledwie połowiczne uchwycenie natury tego wielowariantowego stanu. Jak się bowiem okazuje, oprócz istnienia odmian synestezji międzysensorycznej (np. wizualna percepcja barw wywołana przez określone dźwięki), odnotowano też szereg jej wariantów wykraczających poza ramy 'bodziec zmysłowo-percepcyjny $\rightarrow$ doznanie zmysłowo-percepcyjne', przykładem czego mogą być doznania wywołane przez wyższego rzędu konstrukcje kognitywne będące częścią rozumienia i produkcji języka $^{21}$. Badania wykazały, że bodźcem dla $88 \%$ synestezji są jednostki językowe - grafemy, fonemy i wyrazy. Bliższe obserwacje tych subwariantów dowodzą, że większość z nich pojawia się w rezultacie procesów lingwistycznych per se, a nie zmysłowo-percepcyjnych funkcji niższego rzędu wykorzystywanych w wykrywaniu pisanych lub mówionych form dźwięków ${ }^{22}$.

Aby przybliżyć rolę poznania wyższego rzędu w bodźcach synestezyjnych, Julia Simner odwołuje się w swych rozważaniach
20 J. Simner, Defining synaesthesia ..., s. 2.
21 Ibidem, s. 3.
22 Ibidem. 
do przykładu tych synestetyków, którzy litery alfabetu postrzegają w barwach (np.: ,a" = czerwony) - co, przypomnijmy, było udziałem Nabokova. Problem został sformułowany w następujący sposób: czy kolory liter pojawiają się pod wpływem wizualnej krzywizny i połączeń form pisanych na kartce bądź akustyki dźwięków mowy w czasie głośnego wymawiania tych liter, czy też poprzez skojarzenie ich z kategorią lingwistyczną wyższego rzędu? W pierwszym przypadku mielibyśmy do czynienia z sytuacją zmysłowo-percepcyjną, w drugim natomiast - z bodźcem konceptualnym wyższego rzędu.

Jednym ze sposobów uzyskania odpowiedzi jest obserwacja, czy doznania synestezyjne są zależne od specyficznych form wizualnych określonego typu liter, takich jak rodzaj czcionki, wielkość, kursywa. Badania dowiodły, że większość synestetyków z barwnym widzeniem liter jest niewrażliwa na takie wizualne warianty, co pozwoliło Julii Simner stwierdzić, iż wizualnie różne formy mogą indukować ten sam kolor pod warunkiem, że należą one do tej samej kategorii językowej. A zatem, np. a, A, $a$, a w każdym przypadku może być postrzegane jako czerwone. Synestetyk może więc mówić, że „a” jest czerwone, a nie, że „a” bez kursywy jest czerwone, ale w innej formie przybiera odmienną barwę ${ }^{23}$. Innymi słowy, kolor każdej litery wydaje się zależeć od jej kategorii, a nie od samego zjawiska percepcyjnego.

Opisany wyżej fakt może prowadzić do wniosku, że dla ogromnej większości synestetyków bodziec nie ma natury czysto zmysłowo-percepcyjnej i że jakakolwiek definicja odpowiadająca temu twierdzeniu (tj. warunkowi: zmysł / percepcja) pomija lingwistyczny sposób manifestacji synestezji ${ }^{24}$.

23 Ibidem.

24 Por.: rezultaty badań przeprowadzonych przez Ramachandrana i Hubbarda w: V. S. Ramachandran, E. M. Hubbard, Synaesthesia - A Window Into Perception, Thought and Language, „Journal of Consciousness Studies” 2001, vol. 8, No 12, s. 11-14, wersja on-line: http://cbc.ucsd.edu/pdf/Synaesthesia $\% 20$ -\%20JCS.pdf [dostęp: 3.02.2015]; oraz: iidem, Psychophysical investigations into the neural basis of synaesthesia, „Proceedings of the Royal Society of London” 
Obraz synestezji jest jednak jeszcze bardziej złożony. W celu przybliżenia się do istoty omawianego zjawiska Simner rozważa w swym artykule te jego aspekty, które nadal pozostają kwestiami spornymi:

1. Skoro synestezja jest zjawiskiem wewnętrznie zróżnicowanym, to należy brać też pod uwagę grupę synestetyków letter - color, którzy są wrażliwi na bodźce w postaci wizualnych form niższego rzędu. Są oni określani jako 'lower synaesthetes' ('niżsi synestetycy') - w przeciwieństwie do konceptualnie uwarunkowanych 'higher synaesthetes' ('wyższych synestetyków'). Trzeba jednak podkreślić, iż chodzi tu o grupę stosunkowo nieliczną. Zdecydowana większość reaguje na pojęcia konceptualne i/lub kategoryzację bodźca.

2. Nawet w grupie 'wyższych synestetyków' mogą istnieć przypadki nieznacznej zmiany postrzeganego koloru litery pod wpływem jej formy wizualnej (np. rodzaju czcionki). Aby to zilustrować, należy wziąć pod uwagę fakt, że większość opublikowanej wiedzy na temat synestezyjnych kolorów liter opiera się na odpowiedziach synestetyków poproszonych o nazwanie postrzeganej barwy. Jeśli synestetyk twierdzi, że dwie różne wizualne formy litery „a" są czerwone, to możemy przyjąć, że forma wizualna nie gra żadnej roli w doświadczeniu synestezyjnym. Nierozstrzygnięty pozostaje jednak problem, czy pod wpływem niewielkich wizualnych zmian formy mogą pojawić się bardziej subtelne zmiany odcienia barwy? Niewykluczone, że synestetyk w obu przypadkach „a” określa jako czerwone, choć jedno 'czerwone' może być bardziej lub mniej nasycone ${ }^{25}$.

Podobne obserwacje poczynili i inni badacze synestezji. David Eagleman wykazał ${ }^{26}$, że wizualne formy liter mogą mieć wpływ

2001, B 268, s. 979-983, wersja on-line: http://cbc.ucsd.edu/pdf/Synaesthesia\%20 -\%20P\%20Royal\%20Soc.pdf [dostęp: 5.02.2015].

25 Odnotowano, że w pewnych przypadkach zmiana czcionki powoduje znaczące zmiany intensywności barw synestezyjnych. Więcej na ten temat - patrz: J. Simner, Defining synaesthesia..., s. 4.

26 D. Eagleman, What has large-scale analysis taught us?, Referat wygłoszony na 5. Spotkaniu Towarzystwa Synestezyjnego Zjednoczonego Królestwa, Brighton 2010, podaję za: J. Simner, Defining synaesthesia ..., s. 4. 
na ich barwę. Litery podobne kształtem (np. „E” i „,3”) mogą być bardziej zbliżone kolorystycznie niż litery znacznie się od siebie różniące (np. „E” i „X”). Podobnie Mills i in. ${ }^{27}$ na podstawie przeprowadzonych obserwacji dowodzą, że wizualne podobieństwo liter może wyznaczać sposób, w jaki kolory są transferowane w alfabecie bilingwalnych synestetyków; np. rosyjska litera „И” i arabska „N”, „Я” i „R" przybierają podobne barwy dla angielsko-rosyjskich bilingwalnych synestetyków. Można zatem powiedzieć, że system doznań synestezyjnych, przynajmniej do pewnego stopnia, zbudowany jest na podstawie cech zjawisk percepcyjnych.

Słuszności takiego podejścia zaprzeczają Uta Jürgens i Danko Nikolić ${ }^{28}$. Przeprowadzone przez nich badania wykazały, że choć podobne kształty znaków graficznych wywołują wrażenia podobnych kolorów, to otoczenie, w którym się pojawiają, nie pozostaje bez wpływu na jakość tych doznań. Znak graficzny, który można odczytać jako literę „S” i cyfrę „5”, wywołuje wrażenie koloru uzależnione od kontekstu: jeśli jego znaczenie można interpretować jako cyfrę 5, wówczas barwa będzie inna niż wtedy, gdy znajdzie się wśród innych liter, dając możliwość odczytania go jako S, co świadczy o tym, że w powstanie zjawiska synestezji grafem-kolor zaangażowany jest czynnik semantyczny. W związku z tym Nikolić zaproponował przeformułowanie definicji synestezji rozu-

${ }^{27}$ C. Mills, M. L. Viguers, S. K. Edelson, A. T. Thomas, S. L. Simon-Dack, J. A. Innis, The color of two alphabets for a multilingual synesthete, „Perception” 2002, vol. 31, s. 1381, wersja on-line: https://www.researchgate. net/publication/10983904_The_color_of_two_alphabets_for_a_multilingual_ synesthete [dostęp: 5.02.2015].

${ }_{28}$ U. M. Jürgens, D. Nikolić, Ideaesthesia: conceptual processes assign similar colours to similar shapes, „Translational Neuroscience” 2012, vol. 3, No 1, s. 22-27, http://www.daysyn.com/JuergensNikolic2012Ideaesthesia.pdf [dostęp: 8.02.2015]; oraz D. Nikolić, Is synaesthesia actually ideaesthesia? An inquiry into the nature of the phenomenon, Proceedings of the Third International Congress on Synaesthesia, Science \& Art, Granada, Spain, 2009, April 26-29; http://www.danko-nikolic.com/wp-content/uploads/2011/09/Synesthesia2009-Nikolic-Ideaesthesia.pdf [dostęp: 8.02.2015]. 
mianej tradycyjnie jako współwystępowanie doznań typowych dla różnych zmysłów w następujący sposób:

Synaesthesia is a phenomenon in which a mental activation of a certain concept or idea is associated consistently with a certain perception-like experience ${ }^{29}$.

W kwestii percepcyjnej i konceptualnej natury synestezji Julia Simner wysuwa jeszcze jedną hipotezę: możliwe, że czynnik percepcyjno-wizualny nie odgrywa absolutnie żadnej roli w stymulowaniu doznań synestezyjnych. Synestezyjne barwy liter, uwarunkowane ich kształtem, pojawiają się na bardzo wczesnym etapie życia człowieka i gdy już zostaną w pełni ustalone, tj. gdy zostaną utrwalone pary liter o zbliżonym kolorze, doznanie synestezyjne może stać się niewrażliwe na cechy wizualne niższego rzędu ${ }^{30}$. Innymi słowy, dorosły synestetyk doświadczający kolorów liter może nadal być stymulowany przez konceptualne kategorie liter wyższego rzędu, nawet jeśli podstawą dla przyjętych w dzieciństwie par liter i barw były cechy percepcyjne. Pamiętajmy jednak, że twierdzenie to można rozpatrywać jedynie w kategoriach hipotezy.

W rezultacie ustaleń i licznych wątpliwości dotyczących cech i natury synestezji, Simner proponuje przyjęcie takiej definicji, która ujmowałaby to zjawisko jako nietypowe, oparte na genetycznych podstawach połączenie między różnymi, odseparowanymi zwykle od siebie, funkcjami mózgu (np. funkcjami rozpoznawania liter i kolorów), co znajduje swoje odzwierciedlenie w pochodzącym z zakresu neuronauk określeniu go jako hiperasocjacje między ośrodkami w mózgu ${ }^{31}$. Natomiast różnorodność natury tego zjawiska powinna być, jej zdaniem, ujęta w odmianach synestezji.

29 D. Nikolić, Is synaesthesia actually ideaesthesia?..., s. 3 [Synestezja - to zjawisko, w którym mentalna aktywacja określonych pojęć lub idei jest związana z określonym doświadczeniem percepcyjnym - przeł. A. G.].

30 J. Simner, Defining synaesthesia..., s. 4.

31 Ibidem, s. 9-12. 


\section{Mechanizm i źródła synestezji}

W historii badań nad synestezją wielokrotnie podejmowano próby wyjaśnienia mechanizmu tego zjawiska. W związku z tym pojawiło się wiele hipotez dotyczących jej natury ${ }^{32}$ :

1. Źródeł skojarzeń międzyzmysłowych upatrywano w wybujałej wyobraźni lub w chęci skupienia na sobie uwagi innych i przedstawienia samych siebie jako osoby inne, w pewien sposób szczególne.

2. Wrażenia synestezyjne pochodzą $\mathrm{z}$ takich wspomnień z okresu dzieciństwa, jak na przykład pokolorowane cyfry w książkach lub zabawa kolorowymi magnesami na lodówkę.

3. Skojarzenia międzymodalne wynikają ze skłonności do metaforycznego posługiwania się językiem. Konstrukcje metaforyczne łączące doznania pochodzące od różnych zmysłów są przecież powszechnie używane w codziennej komunikacji.

4. Doznania synestezyjne pojawiają się pod wpływem środków farmakologicznych lub narkotyków.

Żadna z tych hipotez nie dostarczyła jednak satysfakcjonujących wyjaśnień i uzasadnień. Istniały natomiast poważne zastrzeżenia, które nakazywały ich odrzucenie. Na przykład, chęć przyciągnięcia uwagi innych nie znajduje potwierdzenia w rozmowach przeprowadzonych z synestetykami lub w ich wspomnieniach. Początkowo, w dzieciństwie, są oni przekonani, że doświadczane przez nich wrażenia są w równym stopniu udziałem wszystkich ludzi. Gdy natomiast zaczynają o tym mówić, są zwykle wyśmiewani lub przynajmniej wywołują zdziwienie, co uczy ich milczeć na temat swych doznań. Sean Day wspomina też o przypadkach, gdy osoby z doznaniami międzyzmysłowymi odsyłano do „specjalistów”, którzy mylnie diagnozowali u nich schizofrenię lub po prostu szaleństwo ${ }^{33}$. Co cieka-

32 V. S. Ramachandran, E. M. Hubbard, Synaesthesia - A Window Into Perception..., s. 4-5.

33 Patrz: S. A. Day, Some demographic and socio-cultural aspects of synesthesia, [w:] L. Robertson, N. Sagiv (red.), Synesthesia: Perspectives from Cognitive Neuroscience, Oxford University Press, New York 2005, s. 18. 
we, zdarzało się to również w Stanach Zjednoczonych i Kanadzie, gdzie znajdują się obecnie największe ośrodki badawcze zajmujące się synestezją. Mimo więc coraz większej świadomości społecznej na temat natury tego zjawiska, synestetycy, w obawie przed wyśmianiem, błędną diagnozą i poddaniem leczeniu, często wolą utrzymywać swoje doświadczenia w sekrecie.

Szukanie źródeł synestezji we wspomnieniach wiąże się z kolei z poważnym zastrzeżeniem wynikającym z odpowiedzi na nasuwające się pytania: Dlaczego tylko niektórzy ludzie mają takie wspomnienia? Dlaczego tylko określona grupa bodźców jest w stanie wywołać synestezję? Dlaczego zatem mówi się o genetycznych podstawach tego zjawiska?

Trzecia $\mathrm{z}$ wymienionych hipotez zawiera w sobie klasyczny błąd naukowy: próbuje jedno nieznane zjawisko wyjaśnić poprzez inne, nie do końca wyjaśnione. Skoro stosunkowo niewiele wiadomo na temat neurologicznych podstaw metafory, mówienie, że synestezja jest tylko metaforą, nie wyjaśnia ani synestezji, ani metafory. Ostatnia hipoteza zaś jest prawdziwa, ale tylko w odniesieniu do określonej, ograniczonej grupy osób. Zgodnie z jednym z wyjaśnień, pewne stosowane w medycynie środki uruchamiają mechanizm fizjologiczny podobny do tego, który stanowi podstawę dziedzicznie uwarunkowanej synestezji. Jak jednak zauważają Ramachandran i Hubbard ${ }^{34}$, istnieje możliwość, że farmakologicznie wywoływana synestezja nie jest oparta na tych samych mechanizmach neurologicznych, co synestezja wrodzona. Poza tym nie każdy, kto przyjmuje środki psychodeliczne, doświadcza wrażeń synestezyjnych. Prawdopodobnie tylko osoby z wrodzoną skłonnością do wrażeń międzymodalnych będą ich doznawać pod wpływem tej kategorii leków.

Jak zauważa Magdalena Senderecka, najwięcej o naturze synestezji mogą powiedzieć badania psychofizjologiczne, a ich wyniki świadczą na rzecz percepcyjnego charakteru tego zjawiska,

34 V. S. Ramachandran, E. M. Hubbard, Synaesthesia - A Window Into Perception..., s. 5. 
opartego na określonych podstawach neuronalnych, co świadczy o braku słuszności wspomnianych wyżej hipotez. ,Jeśli zatem - pisze Senderecka - synestetyk deklaruje, iż słysząc słowo widzi określoną barwną plamę, to rzeczywiście ją widzi, a nie tylko wyobraża ją sobie, przypomina czy też metaforycznie łączy z dźwiękiem"35.

$\mathrm{Na}$ inną prawdopodobną przyczynę synestezji wskazali Ramachandran i Hubbard ${ }^{36}$, odwołując się przy tym do badań, które przeprowadzili Daniel Smilek, Mike J. Dixon, Cera Cudahy i Philip M. Merikle ${ }^{37}$. Przedstawiona przez nich hipoteza opiera się na danych z zakresu neuronauki. Biorąc pod uwagę najczęściej występującą odmianę synestezji grafem - kolor, ustalili, że ośrodek w mózgu odpowiedzialny za widzenie graficznych form cyfr i liter znajduje się obok ośrodka odpowiedzialnego za percepcję kolorów. Niewykluczone zatem, że synestezja powstaje w wyniku połączenia obydwu ośrodków. Z kolei, skoro synestezja ma charakter dziedziczny i pojawia się w obrębie rodziny, Ramachandran i Hubbard przypuszczają, że owe połączenia między ośrodkami w mózgu są spowodowane mutacją pojedynczego genu, który odpowiada za połączenie między ośrodkami położonymi w różnych częściach mózgu.

Mechanizm powstawania synestezji na gruncie psychofizjologicznym i neurologicznym próbuje też wyjaśnić hipoteza synestezji niemowlęcej, którą w swoim artykule przybliża Rogowska ${ }^{38}$. Hipoteza ta zakłada, że we wczesnym niemowlęctwie wszystkie dzieci doświadczają synestezyjnej percepcji:

W momencie urodzenia kora mózgowa jest jeszcze bardzo niedojrzała. Pod względem anatomicznym wiele komórek nie zakończyło jeszcze migracji

35 M. Senderecka, Synestezja..., s. 268.

36 V. S. Ramachandran, E. M. Hubbard, Synaesthesia $-A$ Window Into Perception..., s. 9.

37 D. Smilek i in., Synaesthetic Photisms Influence Visual Perception, „Journal of Cognitive Neuroscience" [MIT] 2001, vol. 13, No 7, s. 930-936, wersja on-line: http://www.daysyn.com/Smileketal2001b.pdf [dostęp: 4.02.2015].

38 A. Rogowska, Czy synestetycy sa wśród nas?, „Modelowe Nauczanie” 2004, nr 7, s. 38; por. też: V. S. Ramachandran, E. M. Hubbard, Synaesthesia - A Window Into Perception..., s. 9-10. 
do odpowiedniej okolicy kory, połączeń między komórkami jest mało, a wiele zachowań noworodka jest kontrolowanych przez śródmózgowie. Gdy mózg się rozwija, powstaje nadmiar połączeń, które przestają funkcjonować $\mathrm{w}$ wyniku zdobywania doświadczeń. Te chwilowe połączenia istnieją nie tylko pod względem anatomicznym, ale mogą też funkcjonować. W pierwszych dwóch miesiącach życia w reakcji na bodziec słuchowy zostaje pobudzona nie tylko kora słuchowa (okolice skroniowe), ale również wzrokowa (okolice potyliczne). Wczesna kora mózgowa nie jest więc tak dobrze wyspecjalizowana, jak w późniejszym okresie życia.

Ta przejściowa synestezja przypuszczalnie odgrywa ważną rolę przystosowawczą w rozwoju funkcji poznawczych. Większa liczba połączeń międzymodalnych u niemowląt być może ułatwia nabywanie języka - nazywanie i różnicowanie obiektów na podstawie łączenia cech pochodzących z różnych zmysłów, na stosunkowo niskim poziomie przetwarzania informacji. W dalszych etapach rozwoju dochodzi do ograniczenia międzymodalnych koneksji i, w konsekwencji, do ścisłej specjalizacji modalności w odbiorze i analizie specyficznych informacji oraz poszczególnych cech postrzeganych obiektów ${ }^{39}$.

Jak twierdzi Rogowska, koncepcje synestezji niemowlęcej, a także synestezji silnej i słabej ${ }^{40}$ skłaniają nas do przypuszczeń, że wszyscy posiadamy zdolność synestezji, która objawia się szczególnie we wczesnym dzieciństwie. Zdolność ta stanowić może podstawę do wykształcenia się skojarzeń międzyzmysłowych na wyższym poziomie organizacji umysłowej. Co ciekawe,

Wraz z rozwojem i specjalizacją mózgu w odbiorze i przetwarzaniu specyficznych informacji zmysłowych, synestezja zanika u większości z nas. Ale w niektórych przypadkach może się znów pojawić - jak np. pod wpływem środków halucynogennych czy też na skutek zmian nowotworowych czy uszkodzeń przypadkowych mózgu - kiedy to stałe połączenia między różnymi zmysłami zdają się pełnić rolę kompensacyjną ${ }^{41}$.

39 Patrz: A. Rogowska, Czy synestetycy sa wśród nas?..., s. 38.

40 Rozróżnienie na synestezję silną i słabą zostało omówione dalej w rozdziale Synestezja w roli metafory.

${ }^{41}$ A. Rogowska, Czy synestetycy są wśród nas?..., s. 38. 
Rogowska porusza też problem możliwości stymulowania synestezji. Na podstawie obserwacji i badań wyciąga wniosek, że istotne znaczenie dla wykształcenia się synestezji mają nie tylko czynniki genetyczne, ale również środowiskowe:

Wielu synestetyków twierdzi, że miało w dzieciństwie silniejsze skojarzenia i bardziej wyraziste, aniżeli w dorosłości. Można więc przypuszczać, że istotne znaczenie dla utrzymania się synestezyjnych połączeń międzyzmysłowych stanowi częste wykorzystywanie swoich współwrażeń w procesach zapamiętywania czy też $\mathrm{w}$ twórczości artystycznej. Wydaje się, iż istotną rolę stymulacyjną dla synestezji pełni świadomość swoich doznań. W tym pomocna wydaje się wiedza rodziców, wychowawców i nauczycieli na temat synestezji, ich uważna akceptacja i współpraca w rozwijaniu czy utrzymaniu synestezji poprzez pokazanie sposobów wykorzystania współodczuć w codziennym życiu. Szczególne znaczenie miałoby to w pierwszych latach życia ${ }^{42}$.

Rozważania dotyczące źródeł i mechanizmu synestezji prowokują do zadania jeszcze jednego pytania: skąd pochodzą wrażenia doświadczane, zwłaszcza w przypadku synestezji lingwistycznej (ideostezji ${ }^{43}$ ), podczas percepcji znaków graficznych i fonemów? W literaturze naukowej podaje się kilka hipotez wyjaśniających to zjawisko. Cztery z nich przytacza i omawia w swoim artykule Peter Hancock $^{44}$ :

1. Skojarzenia są wyuczane, być może poprzez książki dzieciństwa i zabawki, w których litery pojawiały się na przykład w określonych kolorach. Pamięć o tych skojarzeniach ulega jednak zatarciu w wyniku dziecięcej amnezji.

2. Skojarzenia mają charakter zjawisk „naturalnych": „A” jest „oczywiście” czerwone. Dzieje się tak w rezultacie połączenia czynników genetycznych i rozwojowych.

42 Ibidem, s. 45.

43 Patrz dalej: Odmiany synestezji.

44 P. Hancock, Synesthesia, alphabet books, and fridge magnets, [w:] J. Simner, E. M. Hubbard (eds), The Oxford Handbook of Synesthesia, Oxford University Press, Oxford 2013, s. 83-84, wersja on-line: http://philpapers.org/rec/Hansab-2 [dostęp: 16.03.2014]. 
3. Skoro synestezja ma podłoże genetyczne i występuje w kręgach rodzinnych, kolory są do pewnego stopnia „uczone” przez rodziców. Informacja o kolorze postrzeganym przez rodziców stanowi sugestię, która wpływa na kształtowanie się kolorystycznych doznań dzieci.

4. Barwy są całkowicie arbitralne, tworzone przez przypadkowe połączenia w rozwijającym się mózgu.

Ostatnie badania wskazały na potrzebę docenienia wpływu czynnika środowiskowego na kształtowanie się doznań synestezyjnych. Hancock powołuje się na dwa opisane w literaturze naukowej przypadki, gdy kolory pochodziły od alfabetycznych magnesów na lodówkę. Jednym z nich jest przykład kobiety, umownie określonej jako AED, z ustaloną synestezją grafem-kolor, przedstawiony w artykule Nathana Witthofta i Jonathana Winowera ${ }^{45}$. Jak wykazały testy, u AED kolory zostały przyporządkowane do liter z pewną zauważalną regularnością, która skłoniła badaczy do poszukiwania wyjaśnień twego zjawiska w dziecięcych doświadczeniach synestezyjnych. Okazało się, że układ ten nie był przypadkowy: AED w dzieciństwie dostała od rodziców zestaw magnesów na lodówkę w postaci kolorowych liter, a ich barwy, utrwalone w pamięci, w dużym stopniu odpowiadają jej synestezyjnym skojarzeniom. W wieku trzech lat, po wyjeździe do Rosji, AED poznawała litery alfabetu cyrylickiego i przyporządkowała im określone barwy. Analiza połączeń kształtów i kolorów dowiodła, że wszystkie pary barw i liter rosyjskich pasowały do wizualnie podobnych liter łacińskich z prawie doskonałą korelacją odcieni ich barw. Co ciekawe, do zbieżności tej doszło mimo niekiedy całkowicie odmiennego brzmienia fonemów stojących za podobnymi do siebie literami. Z drugiej jednak strony, w alfabecie rosyjskim znajdziemy szereg liter, które pod względem formy graficznej wprawdzie nie wykazują podobieństwa do żadnej litery alfabetu łacińskiego, ale mają swoje ekwiwalenty

45 N. Witthoft, J. Winawer, Synesthetic colors determined by having colored refrigerator magnets in childhood, „Cortex” 2006, http://psych.nyu.edu/winawerlab/Publications/papers/witthoft_winawer_cortex_2006.pdf [dostęp: 6.02.2015]. 
fonetyczne, np.: F - Ф, P - П, G - Г, L - Л, D - Д. W omawianym przypadku dziesięciu takim właśnie literom rosyjskim przyporządkowane zostały kolory ich fonetycznych odpowiedników liter alfabetu łacińskiego. AED ukształtowała zatem kolory dla nowo poznanego alfabetu na podstawie kształtu i brzmienia bliskich ekwiwalentów w znanym alfabecie łacińskim ${ }^{46}$. Podobieństwo wizualne było jednak dominującym czynnikiem wyznaczającym kolor doświadczanych liter rosyjskich ${ }^{47}$.

Interesujące są też rezultaty badań i eksperymentów, które wykazały, że kolory synestezyjne przyporządkowywane są poszczególnym obiektom graficznym w kolejności wyznaczonej przez kolejność ich poznawania w dzieciństwie ${ }^{48}$. Cyfry i litery są uczone we wczesnym dzieciństwie i przybierają swoje własne idiosynkratyczne kolory. Natomiast nazwy dni tygodnia i miesięcy w ich formie pisanej poznawane są przez dzieci wtedy, gdy kolory liter już zostały ustalone. Zaobserwować można w związku z tym pewną tendencję: nazwy miesięcy przyjmują kolor pierwszej litery, nazwy zaś dni tygodnia, przyswajane z reguły wcześniej niż nazwy miesięcy, rzadziej poddają się kolorystycznemu wpływowi litery inicjującej.

Co się tyczy trzeciego hipotetycznego źródła pochodzenia barw, zgodnie z którym asocjacje kolorystyczne są ,uczone” przez członków rodziny, to nie znalazło ono potwierdzenia w badaniach przeprowadzonych wśród rodzin wyróżniających się doznaniami międzymodalnymi. Nie znaleziono wspólnego „wzoru” asocjacji w zwykle licznej grupie osób powiązanych więzami krwi, doświadczających synestezji lingwistyczno-barwnej ${ }^{49}$.

46 Podobne zjawisko zaobserwowali Aleksandra Mroczko-Wąsowicz i Danko Nikolić: A. Mroczko-Wąsowicz, D. Nikolić, Colored alphabets in bilingual synesthets, [w:] J. Simner, E. M. Hubbard (eds), The Oxford Handbook of Synesthesia..., ss. 165-180; wersja on-line: http://philpapers.org/rec/ MROCAI [dostęp: 16.03.2014].

47 N. Witthoft, J. Winawer, Synesthetic colors..., s. 4.

48 Por.: P. Hancock, Synesthesia, alphabet books, and fridge magnets..., s. 94.

49 Ibidem, s. 96. 
Niebagatelne znaczenie $\mathrm{w}$ kształtowaniu się korelacji ma też czynnik lingwistyczny. Badania nad rolą czynnika lingwistycznego i konceptualnego w synestezyjnym postrzeganiu świata, które przeprowadzili Jamie Ward i Julia Simner ${ }^{50}$, wykazały, że skojarzenia międzymodalne mogą mieć swoje źródło w wiedzy i umiejętnościach lingwistycznych synestetyka. Na przykład, w przypadku synestezji leksykalno-smakowej na rodzaj odczuwanego smaku mogą mieć wpływ kojarzone z nim fonemy (ich porządek i kombinacja) lub asocjacje semantyczne. I tak, fonemy /I/, /n/, /s/ mogą wywoływać smak „mince”/mins/, „Barbara” smakuje „,rhubarb”, „bar” zaś

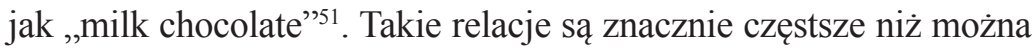
by oczekiwać i połączone szczególnie z obiektami (np. z pożywieniem) znanymi od wczesnego dzieciństwa. Wydaje się zatem, że tego typu skojarzenia mogą być uczone w czasie przyswajania języka ${ }^{52}$.

\section{Cechy synestezji}

Rezultaty badań nad synestezją pozwalają określić pewne cechy charakterystyczne dla tego zjawiska ${ }^{53}$ :

1. Synestezyjne współodczucie pojawia się w bliskim otoczeniu ciała w przypadku telereceptorów (słuchu, wzroku lub węchu, np. w synestezji kolorowego słyszenia osoba widzi kolorowe kształty pojawiające się na zewnątrz jakby na ekranie oddalonym od oczu o kilka centymetrów) bądź wewnątrz ciała osobnika dla kontaktoreceptorów (np. odczucia smaku, dotyku powierzchni szorstkiej lub gładkiej czy też odczucie bólu).

50 J. Ward, J. Simner, Lexical-gustatory synaesthesia: linguistic and conceptual factors, „Cognition” 2003, vol. 89, s. 237-261; http://www.daysyn. com/WardSimner2003.pdf [dostęp: 6.02.2015].

51 Ibidem, s. 250.

52 Por. P. Hancock, Synesthesia, alphabet books, and fridge magnets..., s. 96-97.

53 Podaję za: A. Rogowska, Czy synestetycy są wśród nas?..., s. 31-32. 
2. Wrażenia o charakterze synestezyjnym są wywoływane natychmiastowo i mimowolnie. Percepcja stymulowanego zmysłu wyzwala jednocześnie współwrażenie w innej modalności zmysłowej. Synestetyk nie ma wpływu na to, kiedy i w jaki sposób będzie doznawać współodczuć, jakkolwiek koncentracja uwagi może oddziaływać na siłę i świadomość skojarzeń. Dotychczasowe badania potwierdziły jednak automatyczne występowanie synestezji i jej percepcyjny charakter.

3. Synestezyjne skojarzenia nie są złożonymi obrazami rzeczywistych zjawisk świata, jak np. krajobrazy, lecz prostymi i abstrakcyjnymi doświadczeniami, np. koloru (w paski, prążki lub cętki innej barwy, o kształtach kulistych bądź kanciastych figur i brył geometrycznych).

4. Synestezje mają charakter stałych zjawisk towarzyszących percepcji i nie zmieniają się w ciągu życia. Określone bodźce zawsze wywołują takie same współwrażenia, np. tonacja E-dur będzie miała dla danego synestetyka zawsze (np.) żółty kolor.

5. Synestezja jest idiosynkratyczna - nie ma ludzi o dokładnie takich samych skojarzeniach międzymodalnych.

Badając różne przypadki synestezji, Richard Cytowic sformułował kryteria, które pozwalają zdiagnozować synestezję kliniczną i tym samym postawić granicę między synestezją rozważaną jako zdolność wrodzoną oraz synestezją nabytą w wyniku działania narkotyków, epilepsji lub uszkodzenia mózgu. Kryteria te stanowią dla nas ważne źródło wiedzy o cechach synestezji z perspektywy badań medycznych $^{54}$ :

1. Synestezja jest mimowolna, ale wywoływana przez pewien bodziec.

Synestezji nie można zahamować ani stłumić, ale nie można jej też świadomie wywołać. Pojawia się automatycznie, w odpowiedzi

${ }^{54}$ R. Cytowic, Synesthesia: A Union of the Senses, MIT, Cambridge 2002, s. 67-70; idem, The Man Who Tasted Shapes, MIT, Cambridge 2003, s. 76-79; patrz również: V. S. Ramachandran, E. M. Hubbard, Synaesthesia - A Window Into Perception..., s. 6-8. 
na bodziec. Nawet cyfra pojawiająca się w sposób niedostrzegalny wywołuje odczucie koloru. W zależności od stopnia koncentracji uwagi, doświadczenia synestezyjne przybierają postać osłabioną (np. przy dużym zaangażowaniu osoby w rozmowę na inny temat lub w jakieś zajęcie czy wykonywaną pracę) lub intensywną. Cytowic podaje w tym miejscu przykład ilustrujący to zjawisko i pozorny wpływ świadomości na doznawane wrażenia: ,When working at my computer I am oblivious to everything around me, and so I'm not really aware of the colors the clicking of my keyboard makes as I type" ${ }^{55}$. Nie oznacza to jednak, że doznania międzysensoryczne można kontrolować siłą woli. Jak wynika z relacji synestetyków, świadomy i celowy powrót do doznanych odczuć i powtórne ich przeżycie czy dokładniejsze przyjrzenie się im, mimo starań, nie są możliwe.

2. Synestezja jest projektowana w przestrzeni.

Przez projekcję należy rozumieć, że obiekt postrzegany znajduje się „na zewnątrz”, a nie w wyobraźni. Na przykład, podczas wizualizacji synestezja jest projektowana na „ekran” oddalony od twarzy synestetyka. Projektowane wrażenia są doświadczane w pobliżu ciała, w zasięgu ręki, nie dalej. To samo dotyczy doznań kinetycznych, które zwykle towarzyszą obiektom postrzeganym: dostrzegany ruch występuje blisko ciała. Należy przy tym pamiętać, że obiekty postrzegane pojawiają się na krótką chwilę i następnie znikają. W odniesieniu do kolorowego słyszenia, Harrison i Baron-Cohen ${ }^{56}$ ustalili, że barwa nie znajduje się ani w polu widzenia, ani nie jest mentalnie wyobrażana, biorąc pod uwagę jedyne dwa miejsca dostępne doznaniom niesynestetyków. Bez względu na to, czy synestezje są wyraźnie odczuwane jako zewnętrzne, z pewnością

55 R. Cytowic, Synesthesia: A Union of the Senses..., s. 67 [„Gdy pracuję na komputerze, zapominam o wszystkim wokół mnie, więc nie jestem do końca świadomy kolorów, jakie pojawiają się, gdy uderzam w klawisze podczas pisania" - przeł. A. G.].

56 J. Harrison, S. Baron-Cohen, Synaesthesia: Reconciling the subjective with the objective, „Endeavour” 1995, No 19, s. 157-160. Podaję za: R. Cytowic, Synesthesia: A Union of the Senses..., s. 68. 
mają odniesienie przestrzenne, które nie jest ani wyobrażane, ani pochodzące z siatkówki oka ${ }^{57}$.

3. Synestezyjne doznania są stałe i nieciągłe.

Skojarzenia synestetyka są stałe przez całe życie. Jeśli dany dźwięk jest niebieski, to zawsze będzie niebieski. Kontekst, w którym pojawia się bodziec, nie ma wpływu na doznania synestezyjne. Badania wykazały, że doświadczane wrażenia pozostają niezmienne bez względu na sytuacje, w których występują, a stabilność asocjacji jest traktowana jako najlepszy z dostępnych w nauce testów autentyczności synestezji ${ }^{58}$.

Synestetycy nigdy nie doświadczają złożonych obrazów. Ich doznania mają charakter ogólny w tym sensie, że są elementarne i nierozbudowane: kształty plam, linii spiral, kratek, gładkie lub chropowate tekstury, smak słony, słodki bądź metaliczny. Powszechna jest też replikacja wrażeń w symetrii środkowej lub osiowej. Nieciągłość (discrete) dotyczy również znaku czy znaków prezentujących poszczególne wrażenia. Nie są one odczuwane jako samodzielne, oddzielone od bodźców, które je wywołują, lecz jako ich część, np.:

The shapes are not distinct from hearing them - they are part of what hearing $i s$. The vibraphone, the musical instrument, makes a round shape. Each is like a little gold ball falling. That's what the sound is; it couldn't possibly be anything else 59 .

${ }^{57}$ W sposób graficzny Day przedstawił „miejsce” doświadczanej przez siebie samego synestezyjnej percepcji muzyki w: S. A. Day, Synesthesia: A first person perspective, [w:] J. Simner, E. M. Hubbard (eds), Oxford Handbook of Synesthesia..., s. 905-907. Wątpliwości dotyczące takiego definiowania synestezji przedstawia Julia Simner, która zauważa, że wielu synestetyków zgłasza w wywiadzie doznawanie wrażeń barwnych ,oczami umysłu”, dlatego proponuje, by w definicji synestezji uwzględnić również takie sytuacje: J. Simner, Defining synaesthesia..., s. 8-9.

58 Por.: A. Mroczko-Wąsowicz, D. Nikolić, Colored alphabets..., s. 166.

59 R. Cytowic, Synesthesia: A Union of the Senses..., s. 69 [,Kształty nie są oddzielone od ich słyszenia - są częścią tego, co jest słyszane. Wibrafon, instrument muzyczny, wywołuje kształt okrągły. Każdy kształt jest jak upadająca mała złota piłeczka. Oto czym jest dźwięk; raczej nie może być niczym innym" - przeł. A. G.]. 


\section{Synestezja jest pamięciowa.}

Wrażenia synestezyjne są zwykle łatwiej zapamiętywane niż wywołujący je bodziec. ,She had a green name - I forget, it was either Ethel or Vivian". W tym przykładzie imiona zostały pomylone, ponieważ obydwa są zielone, ale synestezyjna zieleń została zapamiętana. Istnieje silne powiązanie między synestezją i hipermnezją, zdolnością pamięci do odtwarzania utrwalonych śladów przeżyć psychicznych. Wielu synestetyków wykorzystuje swoją zdolność jako pomoc mnemoniczną.

5. Synestezja jest emocjonalna.

Synestetycy są całkowicie przekonani o tym, że ich doznania są rzeczywiste. Wrażenia synestezyjne są wyzwalane przez układ limbiczny, dzięki czemu pojawia się silny stan emocjonalny i uczucie niezachwianej pewności, które synestetycy łączą ze swymi neuronalnymi doświadczeniami. Co więcej, procesy te zachodzą w tej części mózgu, w której istnieją anatomiczne możliwości łączenia informacji dostarczanych przez różne zmysły.

Co warto zauważyć, doznania synestezyjne są udziałem nie tylko ludzi, którzy mają sprawne narządy zmysłów. Znane są na przykład przypadki kolorowego widzenia wśród osób niedowidzących, a nawet niewidomych. Sabriye Tenberken od urodzenia była osobą niedowidzącą, choć była w stanie rozpoznać twarze i miejsca. Całkowicie wzrok straciła w wieku dwunastu lat. W dzieciństwie fascynowały ją kolory, lubiła malować. I kiedy stało się to niemożliwe, nadal używała barw - tym razem do rozpoznawania obiektów:

As far back as I can remember, numbers and words have instantly triggered colours in me. Take the number 4, for example: it represents the color gold. Five is light green. Nine is vermillion. Telephone numbers, mathematical equations, or any kind of formulas are easier for me to remember, thanks to my old habit of putting colors to numbers. Days of the week as well as months have their colors, too. I have them arranged in geometric formations, in circular sectors, a little like a pie ${ }^{60}$.

60 S. Tenberken, My Path Leads to Tibet: the inspiring story of how one young blind woman brought hope to the blind children of Tibet, Arcade Publishing, New York 2003, s. 21. 
W kategoriach cech charakterystycznych dla doświadczanych przez synestetyków wrażeń rozpatrywać też można ich różnorodność i bogactwo. Opisanie owych doznań zawsze związane będzie z dążeniem do precyzji, która umożliwi oddanie subtelnych niekiedy różnic między poszczególnymi odczuciami.

Przykładem takiej niezwykłej różnorodności, wyjątkowości i bogactwa doznań sensorycznych są barwy. Magdalena Senderecka podkreśla w swojej pracy, że osoby z synestezją lingwistyczną często doświadczają wrażenia barw, których nigdy nie widziały w rzeczywistym świecie. W ich relacjach często pojawiają się kolory hybrydowe, określone na przykład jako czerwonawy niebieski lub białawy zielony. W literaturze naukowej opisany jest też przypadek synestetyka z achromatopsją, u którego percepcja liczb wywoływała wrażenia kolorystyczne mimo zdiagnozowanej u niego ślepoty kolorów. Jak zauważa Senderecka,

Pewnym jest, iż subiektywne przeżycia synestetyków związane z percepcją bodźców zmysłowych różnią się od przeżyć osób, których los nie obdarzył zdolnością międzymodalnego odbioru wrażeń. Można przypuszczać, iż doświadczenie postrzegania dziwnych kolorów musi wynikać ze specyfiki procesu powstawania dodatkowego wrażenia w synestetycznym doznaniu. Na gruncie hipotezy skrzyżowanego pobudzenia można przyjąć, iż nadmiarowe wrażenie zmysłowe powstaje od razu na wyższych korowych etapach przetwarzania informacji zmysłowej, z pominięciem początkowych stadiów całego procesu odbioru bodźców ${ }^{61}$.

Spostrzeżenia te znajdują potwierdzenie w rezultatach badań dotyczących nazw barw używanych przez osoby z synestezją grafem-kolor w porównaniu $\mathrm{z}$ grupą osób nieobdarzonych tym darem $^{62}$. W eksperymencie wzięły udział dwie grupy: pierwszą stanowili synestetycy (55 kobiet i 15 mężczyzn, średnia wieku

61 M. Senderecka, Synestezja..., s. 276.

${ }^{62}$ J. Simner, J. Ward, M. Lanz, A. Jansari, K. Noonan, L. Glover, D. A. Oakley, Non-random associations of graphemes to colours in synaesthetic and non-synaesthetic population, ,Cognitive Neuropsychology” [Psychology Press Ltd.] 2005, No 22 (8), s. 1069-1085, wersja on-line: http://www.daysyn.com/ Simneretal2005.pdf [dostęp: 5.02.2015]. 
- 43,8 roku), druga natomiast składała się z niesynestetyków (236 kobiet i 81 mężczyzn, średnia wieku - 21,6 roku). Wszyscy uczestnicy mieli za zadanie nazwać kolory, z jakimi kojarzą im się litery alfabetu (26) i cyfry (0-9), z tym że grupa kontrolna została rozdzielona na kilka podgrup zróżnicowanych ze względu na sposób sformułowania zadania lub sposób jego realizacji (np. w jednej grupie chodziło o podanie pierwszej nazwy koloru, jaka przychodzi na myśl, gdy widzi się każdą z podanych liter i cyfr; w innej zaś - o podanie nazwy koloru, jeśli przywoływane litery i cyfry kojarzą się z barwami).

Analiza odpowiedzi dowiodła, że synestetycy wykazali się bardzo pogłębionymi opisami kolorów i znacznie większym zasobem określeń barw. Każdy z nich zastosował średnio 45 wyrazów w opisie 26 liter alfabetu, podczas gdy w opisach barw członków grupy kontrolnej wykorzystanych zostało średnio 26,5 wyrazu na osobę. Poza tym synestetycy okazali się znacznie bardziej twórczy w określaniu barw: nazwali 495 odcieni, niesynestetycy zaś - 58. Różnicę w postrzeganiu i określaniu kolorów między tymi dwiema grupami poddanymi eksperymentowi ilustruje na przykład sposób realizacji w odpowiedziach kategorii barwy zielonej. W 195 odpowiedziach udzielonych przez osoby doświadczające wrażeń międzymodalnych pojawiły się 54 odmienne opisy (np.: pea green, jade green, lime green, lettuce green, blackish green, fir tree green, muddy green, bottle green), natomiast w odpowiedziach grupy kontrolnej - zaledwie pięć: green, dark green, lime, emerald i avocado ${ }^{63}$.

Powyższe rezultaty pokazują, że znacznie większe bogactwo opisów barw u osób z synestezją może wynikać z faktu, że doznawane przez nich skojarzenia barw z cyframi i literami są dla nich bardziej realne niż dla członków grupy kontrolnej, którzy po prostu nazywali kolory, nie doświadczając wrażeń wizualnych i nie próbując ich jak najprecyzyjniej opisać. Przede wszystkim jednak potwierdzają one słuszność spostrzeżeń Beata Meiera i Nicolasa

63 Ibidem, s. 1073. 
Rothena ${ }^{64}$, którzy na podstawie od niedawna prowadzonych badań dowodzą, że osoby z synestezją grafem-kolor mają wzmocnioną percepcję kolorów i zwiększoną zdolność ich zapamiętywania.

\section{Odmiany synestezji}

W zależności od kierunku wywoływania wrażeń, synestezja może być jedno- lub obukierunkowa. Z synestezją jednokierunkową mamy do czynienia wówczas, gdy w połączeniu dwóch doświadczeń tylko jedno z nich ma możliwość uruchamiania drugiego, np.: w synestezji kolorowego słyszenia dźwięk wywołuje wrażenie barwy, ale bodziec w postaci barwy nie wyzwala wrażenia dźwięku. W synestezji dwukierunkowej każde z połączonych ze sobą wrażeń może stymulować drugie, a więc w naszym przypadku dźwięk będzie wywoływać doznanie koloru, a kolor - dźwięku ${ }^{65}$.

Rodzaje synestezji ustala się też w zależności od tego, ile zmysłów ze sobą łączy. Najczęściej podstawą zjawiska są dwie modalności, np. doznania wzrokowe i słuchowe. Synestezja wielozmysłowa, łącząca wrażenia doznawane w kilku modalnościach zmysłowych, jest natomiast zjawiskiem stosunkowo rzadkim. Przykładem synestezji czterozmysłowej jest sposób postrzegania świata przez słynnego mnemonistę, Salomona Szereszewskiego, opisany w książce Aleksandra Łurii O pamięci, która nie miała granic (1970). Dźwięki wywoływały u Szereszewskiego doznania światła, barwy, smaku i dotyku. Gdy na przykład słyszał ton o wysokości $50 \mathrm{hz}$ i natężeniu $100 \mathrm{db}$, widział brązową smugę na ciemnym tle z czerwonymi języczkami o kwaśno-słodkim smaku barszczu. Ton $2000 \mathrm{~Hz}$ i 113 db wywoływał u niego „coś w rodzaju fajerwerku

${ }^{64}$ B. Meier, N. Rothen, Grapheme-color synaesthesia is associated with a distinct cognitive style, ,Frontiers in Psychology” 2013, vol. 4, artykuł nr 632, s. 5; http://www.apn.psy.unibe.ch/unibe/philhuman/psy/apn/content/e5638/e6102/ e147979/e380914/MeierRothen_FIF2013_ger.pdf [dostęp: 7.02.2015].

65 Patrz: A. Rogowska, Czy synestetycy sa wśród nas?..., s. 34. 
o kolorze różowo-czerwonym... szorstki pasek nieprzyjemny... nieprzyjemny korzenny smak sosu marynatów... można poranić sobie rękę" ${ }^{66}$. Łuria zauważył, że dla Szereszewskiego każdy dźwięk (dźwięki mowy, ludzkie głosy, tony, szumy) miał określony kształt wzrokowy, smak lub kolor. Samogłoski miały postać prostych figur, spółgłoski zaś postrzegał jako coś twardego, sypkiego, co zawsze zachowuje swój kształt. Podobnie też cyfry wywoływały u niego różnego rodzaju doznania: cyfra 5 była dla niego czymś w pełni zakończonym, podstawowym, w kształcie stożka lub baszty, natomiast 8 określał jako niewinną, niebieskawo-mleczną, podobną do wapna ${ }^{67}$. Szereszewski tak opisywał doznawane wrażenia:

Rozpoznaję nie tylko według obrazów, ale zawsze według całego zespołu doznań, które ten obraz wywołuje. Trudno jest je opisać - to nie jest wzrok ani słuch... To są jakieś ogólne odczucia... Zwykle czuję i smak, i ciężar słowa - nic już nie potrzebuję więcej robić - ono samo przypomina się... to trudno opisać - czuję w ręce - prześlizgnie się coś oleistego - masa drobniutkich kropeczek, ale bardzo lekkich - to jest takie lekkie łaskotanie w lewej ręce $-\mathrm{i}$ nic już więcej nie potrzebuję...68

Doznania synestezyjne mogą powstawać w wyniku percepcji danego bodźca lub w efekcie myślenia o bodźcu bądź wyobrażania go sobie. W zależności od źródła stymulacji wyróżnia się synestezję perceptualną lub konceptualną. Podobnie też synestezyjne współodczucie może być doznawane zewnętrznie (percepcyjnie) lub wewnętrznie (jako wyobrażenie) ${ }^{69}$.

Biorąc pod uwagę kryterium rodzaju modalności zmysłowych, uczeni wyróżniają dwadzieścia potencjalnych konfiguracji doznań w synestezji jednokierunkowej i ogromną możliwość związków międzyzmysłowych w synestezji wielomodalnej. Najbardziej

${ }^{66}$ A. Łuria, O pamięci, która nie miała granic, PWN, Warszawa 1970, s. 2526; podaję za: A. Rogowska, Czy synestetycy sq wśród nas?..., s. 30.

${ }_{67}$ Patrz: M. Senderecka, Synestezja..., s. 265.

68 Ibidem.

69 A. Rogowska, Czy synestetycy są wśród nas?..., s. 35. 
rozpowszechnionymi formami synestezji jednokierunkowej są: synestezja kolorowego słyszenia ${ }^{70}$, kolorowego wąchania i dotykowego smakowania, spośród których z kolei najczęstsza jest chromestezja, inaczej nazywana synopsją i kolorowym słyszeniem (coloured-hearing synaesthesia), w przypadku której bodziec dźwiękowy wywołuje doznania wzrokowe. W zależności od rodzaju stymulacji, można wyróżnić dwa typy synestezji kolorowego słyszenia ${ }^{71}$ :

1. Synestezję leksykalną (lingwistyczną) - jej źródłem są dźwięki mowy: cyfry, litery alfabetu, słowa (imiona, dni tygodnia, słowa znaczące lub wszystkie słowa i fonemy) bądź ich graficzne odpowiedniki. W badaniach Barona-Cohena i jego współpracowników forma synestezji kolorowego słyszenia, w której słowa wywołują wrażenia kolorowych plam, niezwiązanych z poszczególnymi literami czy fonemami, wchodzącymi w skład danego słowa, określona została jako synestezja chromatyczno-leksykalna. Kolejne badania skojarzeń synestezyjnych w tym zakresie przyniosły dalsze rozróżnienie na:

a) synestezję chromatyczno-grafemiczną - poszczególne litery (np. pierwsza litera w wyrazie) nadają kolor całemu słowu;

b) synestezję chromatyczno-fonematyczną - kolor słowa uwarunkowany jest kolorem dominującego fonemu.

Doznania synestezyjne pojawiają się zwykle w postaci kolorowych plam (jedno- lub wielobarwnych, w paski, prążki, kropki innego koloru) albo w postaci kolorowego napisu (poszczególne kolorowe litery bądź całe słowo w jednym kolorze, pisane własnym charakterem pisma lub czcionkami drukowanymi). Jak zauważa Rogowska, synestezja jest cechą wysoce indywidualną, więc choć poszczególne elementy, ogólne tendencje i skojarzenia mogą być podobne, każdy synestetyk ma inny ,alfabet kolorów”72.

${ }^{70} \mathrm{~W}$ nazwie określającej rodzaj synestezji zmysł stymulowany stanowi drugi człon, natomiast pierwszy człon określa wyzwoloną tymże bodźcem synestezję.

71 Klasyfikację rodzajów synestezji podaję za: A. Rogowska, Czy synestetycy sq wśród nas?..., s. 35-37 oraz: M. Senderecka, Synestezja..., s. 266.

72 A. Rogowska, Związi synestezji z muzyka..., s. 86. 
2. Synestezję muzyczną - dźwięki muzyczne wywołują wrażenia kolorowych plam o nieokreślonym kształcie lub kolorowych (poruszających się) form abstrakcyjnych figur geometrycznych. Jej źródłem może być określona wysokość realnego dźwięku lub tonacji muzycznej, barwa konkretnego instrumentu muzycznego bądź głosu ludzkiego. Chromestezja stosunkowo często obserwowana jest u instrumentalistów grających na instrumentach klawiszowych (fortepian, organy, klawesyn, akordeon). Fakt ten, po przeprowadzeniu własnych badań wśród studentów Akademii Muzycznej w Katowicach, potwierdza Aleksandra Rogowska, która podejmuje próbę wyjaśnienia tego fenomenu:

Prawdopodobnie gra akordowa, charakteryzująca się zwiększoną ilością współwystępujących alikwotów, najlepiej przekładana jest na kolory. Gra na instrumentach klawiszowych wymaga też specyficznej wrażliwości na barwę dźwięku, wiążąc się ze wzmożoną pracą wyobraźni ${ }^{73}$.

Krytyk muzyczny Percy Alfred Scholes wyróżnił pięć sposobów występowania synestezji w muzyce ${ }^{74}$ :

a) Kolor kojarzony z całą twórczością poszczególnych kompozytorów, np. muzyka Mozarta określana jest jako niebieska, Chopina - zielona, Beethovena - czarna;

b) Kolory odpowiadają poszczególnym utworom, np. Aida jest niebieska, Latający Holender - mgliście zielony;

c) Kolor koresponduje z tembrem głosu lub barwą dźwięku poszczególnego instrumentu, np. flet - błękitny, klarnet - różowy, instrumenty dęte blaszane - różne odcienie czerwieni;

d) Kolor wiąże się z tonacją muzyczną, np. tonacja E-dur jest niebieska, D-dur - żółta, b-moll - czarna;

e) Kolor kojarzony jest z absolutną wysokością dźwięku, np. dźwięk h jest szary, f - zielony, as - purpurowy.

73 A. Rogowska, Czy synestetycy sq wśród nas?..., s. 42.

74 P. A. Scholes, Colour and Music, „The Oxford Companion to Music” [Oxford University Press, London] 1978, s. 202-210; podaję za: A. Rogowska, Związki synestezji z muzyką..., s. 87-88. 
Poszczególne typy i rodzaje synestezji mogą u niektórych osób współwystępować, u innych natomiast pojawia się tylko jeden rodzaj doznań międzymodalnych.

Choć wszystkie odmiany synestezji mają charakter idiosynkratyczny i nie ma dwóch osób o tym samym zestawie skojarzeń międzymodalnych, wśród synestetyków można jednak zaobserwować pewne tendencje. Odszukanie tych tendencji było jednym z celów pracy badawczej Seana Daya ${ }^{75}$, również synestetyka. Interesująco przedstawiają się wyniki prowadzonych przez niego przez 11 lat badań w grupie osób z synestezją grafem-kolor: litera „A” postrzegana jest jako czerwona ${ }^{76}$ przez $43 \%$ grupy składającej się ze 172 osób; litera „O” jest biała dla 57\% spośród 123 osób; litera „I” postrzegana jako barwna wśród 119 osób, przez 38\% odbierana jest jako biała, przez 28\% jako czarna, 12\% zaś postrzega ją jako szarą. $\mathrm{Z}$ tego wynika, że 78\% widzi ją w barwie achromatycznej. Spośród 92 synestetyków 44\% widzi literę ,Y" jako żółtą.

Co ciekawe, podobne rezultaty osiągnęli badacze podczas eksperymentu dotyczącego korelacji między znakami graficznymi i barwami w grupach synestetyków i niesynestetyków ${ }^{77}$. Analiza zgromadzonych odpowiedzi wykazała, że w grupie osób ze stwierdzoną synestezją grafem-kolor najczęściej pojawiającymi się skojarzeniami w odniesieniu do wymienionych wyżej liter były: A - czerwone, $\mathrm{O}$ - białe, I - białe lub czarne, Y - żółte lub szare $^{78}$. s. $13-14$.

75 S. A. Day, Some demographic and socio-cultural aspects of synesthesia...,

76 Jako kryterium określeń kolorów Day przyjął 11 barw podstawowych dla języka angielskiego: czarną, białą, czerwoną, zieloną, niebieską, żółtą, brązową, szarą, pomarańczową, różową i fioletową, na podstawie klasyfikacji Berlina i Kaya: B. Berlin, P. Kay, Basic Color Terms. Their Universality and Evolution, Berkeley 1969; wersja on-line: http:/www.ucpress.edu/op.php?isbn=9780520076358 [dostęp: 30.06.2014].

77 Patrz: J. Simner, J. Ward, M. Lanz, A. Jansari, K. Noonan, L. Glover, D. A. Oakley, Non-random associations of graphemes to colours..., s. 1069-1085.

78 Ibidem, s. 1077. 
Jak można zauważyć, litery jako całość nie są zbyt kolorowe; postrzegane są raczej w barwach szarych, brązowych, przytłumionych, podczas gdy cyfry odbierane są jako barwne i jaskrawe. Day sugeruje, że w badaniach nacisk powinien być teraz położony na określenie zależności (lub jej braku) między postrzeganą barwą i kształtem geometrycznym obiektu, np.: kolor biały być może kojarzony jest z kołem (litery O i Q), czerwony z trójkątem (A) ${ }^{79}$.

Przeprowadzone przez Daya obserwacje umożliwiły też określenie stopnia częstotliwości występowania poszczególnych odmian synestezji wśród 572 odnotowanych przez niego przypadków tego zjawiska. Grupa synestetyków składała się w 75\% z kobiet i w 24\% z mężczyzn, 1\% stanowią przypadki anonimowe. Należy też zaznaczyć, że niektóre z badanych osób doznawały kilku odmian synestezji.

Tabela 1

Odmiany synestezji i częstotliwość ich występowania

\begin{tabular}{|l|c|c|}
\hline \multicolumn{1}{|c|}{ Odmiana synestezji } & Liczba osób & Procent \\
\hline \multicolumn{1}{|c|}{1} & 2 & 3 \\
\hline kolorowe grafemy & 394 & 68,8 \\
kolorowe jednostki czasu & 134 & 23,4 \\
kolorowe dźwięki muzyki & 106 & 18,5 \\
kolorowe dźwięki (ogólnie) & 82 & 14,3 \\
kolorowe nuty & 62 & 10,8 \\
kolorowe fonemy & 60 & 10,5 \\
kolorowe smaki & 43 & 7,5 \\
kolorowe zapachy & 40 & 6,9 \\
kolorowy ból & 36 & 6,3 \\
kolorowe osobowości & 26 & 4,5 \\
kolorowy dotyk & 25 & 4,0 \\
kolorowa temperatura & 15 & 2,6 \\
kolorowy orgazm & 7 & 1,2 \\
zapach - synestezyjny dźwięk & 4 & 0,6 \\
\hline
\end{tabular}

79 S. A. Day, Some demographic and socio-cultural aspects of synesthesia..., s. 14 . 
Tab. 1 (cd.)

\begin{tabular}{|l|r|r|}
\hline \multicolumn{1}{|c|}{1} & 2 & 3 \\
\hline zapach - synestezyjny smak & 1 & 0,1 \\
zapach - synestezyjna temperatura & 1 & 0,1 \\
zapach - synestezyjny dotyk & 4 & 0,6 \\
dźwięk - synestezyjny zapach & 9 & 1,5 \\
dźwięk - synestezyjny smak & 29 & 5,0 \\
dźwięk - synestezyjna temperatura & 4 & 0,6 \\
dźwięk - synestezyjny dotyk & 25 & 4,3 \\
smak - synestezyjny dźwięk & 1 & 0,1 \\
smak - synestezyjna temperatura & 1 & 0,1 \\
smak - synestezyjny dotyk & 4 & 0,6 \\
temperatura - synestezyjny dźwięk & 1 & 0,1 \\
dotyk - synestezyjny zapach & 2 & 0,3 \\
dotyk - synestezyjny dźwięk & 2 & 0,3 \\
dotyk - synestezyjny smak & 3 & 0,5 \\
dotyk - synestezyjna temperatura & 1 & 0,1 \\
widzenie - synestezyjny zapach & 6 & 1,0 \\
widzenie - synestezyjny dźwięk & 6 & 1,0 \\
widzenie - synestezyjny smak & 11 & 1,9 \\
widzenie - synestezyjna temperatura & 2 & 0,3 \\
widzenie - synestezyjny dotyk & 5 & 0,8 \\
osobowość - synestezyjny zapach & 1 & 0,1 \\
\hline
\end{tabular}

Źródło: S. A. Day, Some demographic and socio-cultural aspects of synesthesia, [w:] L. Robertson, N. Sagiv (eds), Synesthesia: Perspectives from Cognitive Neuroscience, Oxford University Press, Oxford 2005, s. 15.

Inne możliwe kombinacje (smak - synestezyjny zapach, temperatura - synestezyjny zapach, temperatura - synestezyjny smak, temperatura - synestezyjny dotyk) nie wystąiłił w grupie synestetyków poddanych badaniom. Odmiany zestawione $\mathrm{w}$ tabeli nie wyczerpują wszystkich możliwych rodzajów współwystępowania wrażeń zmysłowych. Pokazują jednak, że wśród synestetyków najczęściej występują doznania kolorystyczne.

Omówiona wyżej klasyfikacja odmian synestezji spotyka się ze sprzeciwem ze strony niektórych badaczy lub przynajmniej 
z wątpliwościami i propozycją innego podziału bądź nazewnictwa zjawisk synestezyjnych. Sean Day uważa, że istnieją dwa główne rodzaje „kolorowego słyszenia”: synestezja właściwa i synestezja kognitywna (lub kategorialna) ${ }^{80}$. Z synestezją właściwą mamy do czynienia wówczas, gdy bodziec pochodzący od jednej modalności zmysłowej wywołuje reakcję w innej modalności, np. bodziec słuchowy wywołuje wrażenia typowe dla zmysłu smaku. Synestezja kognitywna związana jest natomiast z kulturowo uwarunkowanym systemem kategoryzacji kognitywnej. Mówiąc inaczej, obiekty, które kultura uczy nas zestawiać obok siebie i w określony sposób kategoryzować, jak litery, cyfry czy nuty muzyczne, otrzymują pewnego rodzaju dodatkową wartość sensoryczną (zmysłową), np. smak, zapach bądź dźwięk. Najczęstszą formą synestezji kognitywnej jest kolorowe widzenie napisanych liter, cyfr, jednostek czasu oraz muzycznych nut i tonacji. Synestetyk może ,widzieć” wówczas kolory przyporządkowane do poszczególnych (artykułowanych lub napisanych/wydrukowanych) samogłosek i/lub spółgłosek, cyfr, dźwięków muzyki bądź nazw dni tygodnia.

O dwóch rodzajach synestezji, percepcyjnej i pojęciowej, piszą Peter Grossenbacher i Christopher Lovelace ${ }^{81}$. W synestezji percepcyjnej reakcję wywołuje percepcja zmysłowego bodźca. W przypadku synestezji pojęciowej natomiast rolę bodźca odgrywa myślenie o określonym pojęciu. Nikolić i Jürgens ${ }^{82}$ z kolei,

$80 \mathrm{~S}$. A. Day, A comparison of true-synesthete and pseudo-synesthete composers, [w:] Prometheus 2000 Conference Proceedings: On the Destiny of Light-Music at the Border of Centuries, red. B. Galeev, Kazan 2000, s. 78; oraz: idem, Some demographic and socio-cultural aspects of synesthesia..., s. 12.

81 P. G. Grossenbacher, C. T. Lovelace, Mechanisms of synesthesia: cognitive and physiological constraints, ,Trends in Cognitive Science" 2001, vol. 5, No 1, s. 36; http:/www.daysyn.com/GrossenbacherLovelace2001.pdf [dostęp: 7.02.2015].

82 U. M. Jürgens, D. Nikolić, Ideaesthesia: conceptual processes assign similar colours to similar shapes, ,Translational Neuroscience” 2012, vol. 3, No 1, 
w związku z niepodważalną ich zdaniem rolą czynnika semantycznego, postulują zmianę nazwy synestezji na ideostezję (idea + aisthesis). Jak dowodzą, współodczuwane doznanie (concurrent) operuje na poziomie sensorycznym, bodziec zaś (inducer) pojawia się z udziałem semantycznego poziomu reprezentacji w większym stopniu niż na niższym poziomie percepcji. Dlatego właśnie synestezja może być rozumiana jako nietypowy rodzaj asocjacji semantycznej ${ }^{83}$. Typowymi przykładami ideostezji będą asocjacje między grafemami i kolorami (tradycyjnie określane jako synestezja grafem-kolor), wyrazami i smakami (synestezja leksykalno-smakowa), między jednostkami czasu i miejscami w przestrzeni.

Biorąc pod uwagę niejednorodną naturę synestezji oraz sugestie badaczy dotyczące istnienia dwóch odmiennych jej źródeł (pojęć i wrażeń zmysłowych), na potrzeby niniejszej pracy został przyjęty podział na synestezję i ideostezję. Pierwsza z nich rozumiana jest jako zjawisko doświadczania wrażeń zmysłowych pod wpływem doznań typowych dla innego zmysłu. Ideostezja zaś oznacza doświadczanie wrażeń sensorycznych pod wpływem bodźca konceptualnego (pojęcie, idea), w odbiór którego zaangażowany jest czynnik semantyczny. Ze względu na powszechność użycia terminu „synestezja” oraz fakt, że zjawisko ideostezji w ujęciu Nikolicia wymaga przeprowadzenia kolejnych badań, w rozdziale poświęconym skojarzeniom typu koncept - wrażenie sensoryczne nazwy „synestezja” i ,ideostezja” używane są wymiennie. Co więcej, do zjawisk o charakterze ideostezyjnym zaliczone zostały przykłady odmiany synestezji nazywanej ordinal linguistic personification.

s. 22-27, http://www.daysyn.com/JuergensNikolic2012Ideaesthesia.pdf [dostęp: 8.02.2015]; oraz: D. Nikolić, Is synaesthesia actually ideaesthesia?..., s. 3.

83 Por.: U. M. Jürgens, D. Nikolić, Synaesthesia as an Ideasthesia-cognitive implications, [w:] J. Sinha, C. Söffing (eds), Synesthesia and Children - Learning and Creativity, Kassel University Press, Kassel 2014, s. 7. 


\section{Ordinal linguistic personification}

Od lat dziewięćdziesiątych wieku XIX w pracach naukowych poświęconych synestezji często mówi się o zjawisku określanym jako sequence personality mapping (ordinal linguistic personification - OLP). Chodzi tu o przypadki, w których uporządkowane sekwencje lingwistyczne, np. litery, liczby, dni tygodnia, miesiące roku, wywołują automatyczną i nieprzepartą chęć nadania im cech osobowych lub osobowościowych: litera ,a" może być zapracowaną matką, numer zaś 9 - kochającym mężem ${ }^{84}$. Przykładem synestetyka $\mathrm{z}$ tą stosunkowo rzadką odmianą doznań jest pisarka Jane Yardley, która ,trzy” widziała jako pyszałkowate i nieprzyjazne, raczej urągliwe, natomiast „dwa" - jako nieśmiałe i wycofane ${ }^{85}$.

Dlaczego sytuacje te są rozpatrywane w kategoriach synestezji, skoro ich istotą nie jest merging of senses? Wyjaśnień w tej kwestii dostarcza Julia Simner ${ }^{86}$ :

1. Podobnie jak w innych wariantach synestezji, OLP dotyczy par wymiarów pochodzących z różnych, niezwiązanych ze sobą w innych sytuacjach modalności, które tu ulegają automatycznemu skojarzeniu.

2. Jak zauważają Simner i Holenstein ${ }^{87}$, sequence personality mappings są stymulowane przez czynnik, który jest najbardziej powszechnym bodźcem synestezji, tj uporządkowane sekwencje lingwistyczne, wywołujące $82 \%$ wszystkich przypadków synestezji.

3. Prawdopodobieństwo wystąpienia sequence personality mapping jest dziesięć razy większe u osób doświadczających

84 Patrz: J. Simner, Defining synaesthesia..., s. 5; J. Simner, E. Holenstein, Ordinal Linguistic Personification as a Variant of Synesthesia, ,Journal of Cognitive Neuroscience" 2007, vol. 19 (4), s. 695; wersja on-line: http://www.daysyn.com/ SimnerandHolenstein2007.pdf [dostęp: 3.02.2015].

85 Colours by numbers, ,The Scotsman”, 30 January 2003; http://www.scotsman.com/news/colours-by-numbers-1-543985 [dostęp: 4.02.2015].

86 J. Simner, Defining synaesthesia..., s. 5.

87 J. Simner, E. Holenstein, Ordinal Linguistic Personification..., s. 694-695. 
synestezji grafem-kolor niż u ludzi bez zdolności synestezyjnych. Jest to tym bardziej istotne, że osoby doznające jednego wariantu synestezji są znacznie bardziej podatne na jej inne warianty. Współwystępowanie OLP i synestezji grafem-kolor sugeruje, że OLP może prezentować sobą wariant synestezji.

4. Simner i Holenstein pokazują, że sposób, w jaki w OLP doznania synestezyjne rozkładają się na poszczególne części wyrazu (wyrazy mają tendencję do 'przyjmowania osobowości’ początkowej litery) odzwierciedla mechanizm działania innych synestezji opartych na sekwencjach. A zatem, na przykład w synestezji grafem-kolor, wyrazy mogą przybierać kolor litery nagłosowej. Świadczy to o istnieniu wspólnego mechanizmu psychologicznego, jakiego należałoby oczekiwać, gdyby obydwie omawiane sytuacje były różnymi manifestacjami tego samego zjawiska.

Simner i Holenstein wskazują też na inne podobieństwa między OLP i synestezją - trwałość w czasie, ostrość itd. Biorąc więc pod uwagę wszystkie te argumenty, można zauważyć, że OLP bardzo mocno przypomina rzeczywisty wariant synestezji. A to prowadzi do wniosku, że synestezja nie może być sprowadzana do zjawiska czysto zmysłowego.

\section{Wielcy wśród synestetyków}

W artykule Czy synestetycy są wśród nas Aleksandra Rogowska podjęła m.in. temat zależności między zdolnościami synestezyjnymi i cechami osobowości ${ }^{88}$. Przeprowadzone przez nią badania potwierdzają, że synestetycy są bardziej wrażliwi na niuanse bodźców muzycznych niż ludzie nieobdarzeni tym darem. Ponadto,

synestetycy mają większe tendencje do twórczości [...] i mogą odnosić ze swej zdolności korzyści w języku żywej wzrokowej wyobraźni już w procesie kodowania, wzbogacając zasoby większą ilością informacji i transformu-

88 A. Rogowska, Czy synestetycy sq wśród nas?..., s. 43-44. 
jąc bodźce na wejściu, dzięki czemu ich percepcja reprezentuje dużo bardziej aktywny proces postrzegania ${ }^{89}$.

Synestezja, zwłaszcza w swojej odmianie grafem-kolor, jest związana ze wzmocnieniem pamięci werbalnej i wizualnej, ze zwiększoną obrazowością i kreatywnością oraz ze wzbogaconym światem doznań ${ }^{90}$. Dowodzi tego Beat Meier, który na przykładzie sieci semantycznej związanej z postrzeganiem litery A w kolorze czerwonym, pokazuje możliwości tworzenia różnorodnych i rozległych połączeń między kolejnymi pojęciami u synestetyka, w przeciwieństwie do bardzo ograniczonej sieci semantycznej, powstającej w przypadku niesynestetyka ${ }^{91}$. Dodatkowe koneksje w sieci mogą stać się podstawą zwiększonej kreatywności, co z kolei wskazuje na istnienie powiązania między synestezją i twórczą pracą artysty.

Na możliwe wyjaśnienie tej zależności uwagę zwrócili Ramachandran i Hubbard ${ }^{92}$. Przeprowadzone przez nich badania wykazały, że mutacja, która najprawdopodobniej przyczynia się do powstania synestezji, wywołuje dodatkową komunikację między różnymi częściami mózgu - małymi obszarami kory odpowiedzialnymi za specyficzny rodzaj percepcji, np. ostrość, wygięcie linii czy odcień koloru. W zależności od tego, w którym i jak bardzo rozległym obszarze do tego dojdzie, może doprowadzić to zarówno do synestezji, jak i do skłonności do łączenia pozornie nie związanych ze sobą pojęć i idei, co inaczej nazywane jest kreatywnością.

Nie ma wątpliwości, że synestezja jest związana z twórczością. Wśród ludzi sztuki synestetycy stanowią liczne grono. Należy do nich kompozytor György Ligeti, który podczas słuchania

\section{Ibidem}

90 Por.: B. Meier, N. Rothen, Grapheme-color synaesthesia is associated with a distinct cognitive style..., s. 2.

91 B. Meier, Semantic representation of synaesthesia, „Theoria et Historia Scientiarum" 2013, vol. 10, s. 129; wersja on-line: http://apcz.pl/czasopisma/index.php/THS/article/view/ths-2013-0006/3524 [dostęp: 5.02.2015].

92 V. S. Ramachandran, E. M. Hubbard, Hearing colors, tasting shapes, „Scientific American” 2003, s. 58; http://cbc.ucsd.edu/pdf/SciAm_2003.pdf [dostęp: 7.02.2015]. 
dźwięków muzyki doznawał wrażeń wizualnych, w tym również kolorystycznych:

I am inclined to synaesthetic perception. I associate sounds with colors and shapes. Like Rimbaud, I feel that all letters have a color. Major chords are red or pink, minor chords are somewhere between green and brown. I do not have perfect pitch, so when I say that $\mathrm{C}$ minor has a rusty red-brown color and D minor is brown this does not come from the pitch but from the letters $\mathrm{C}$ and D. I think it must go back to my childhood. I find, for instance, that numbers also have colors; 1 is steely grey, 2 is orange, 5 is green ${ }^{93}$.

Doznania synestezyjne występowały też u takich kompozytorów, jak Leonard Bernstein, Mikołaj Rimskij-Korsakow, Olivier Messiaen, u których poszczególne tonacje muzyczne lub instrumenty wywoływały wrażenia barw, a ich kompozycje służyły osiągnięciu specyficznych efektów kolorystycznych pod wpływem słyszanych dźwięków. Na przykład, Rimskij-Korsakow w ten sposób opisywał kolory widziane pod wpływem określonych tonacji ${ }^{94}$ :
C-dur białe,
G-dur brązowo-złote, jasne,
D-dur światło dzienne, żółtawe, królewskie,
A-dur przejrzyste, różowe,
E-dur niebieskie, szafirowe, jasne,
B-dur mroczne, ciemnoniebieskie ze stalowym połyskiem,
Fis-dur szarozielone,
Des-dur ciemnawe, ciepłe,
As-dur szarofioletowe,
Es-dur ciemne, mroczne, szaroniebieskawe,
F-dur zielone, przejrzyste (kolor zieleni).

${ }_{93}$ György Ligeti in Conversation with Péter Várnai, Josef Häusler, Claude Samuel, and Himself, Eulenburg Books, London 1983, s. 58; podaję za: S. Shaw-Miller, Synaesthesia, [w:] T. Shephard, A. Leonard (eds), The Routledge Companion to Music and Visual Culture, Routledge, New York 2014, s. 15.

${ }^{94}$ Na podstawie: S. A. Day, Some demographic and socio-cultural aspects of synesthesia..., s. 22-23. 
Franz Liszt, gdy rozpoczął pracę kapelmistrza w orkiestrze weimarskiej, zadziwił muzyków, gdy powiedział: „O, please, gentleman, a little bluer, if you please! This tone type requires it". Innym razem z kolei zwrócił uwagę: „That is a deep violet, please, depend on it! Not so rose!"95 Do komponowania muzyki niebieskiej, różowej i fioletowej zachęcała córkę matka słynnej amerykańskiej pianistki i kompozytorki ${ }^{96}$. Amy Beach kojarzyła bowiem tonacje muzyczne z barwami: C-dur było białe, Fis-dur czarne, E-dur żółte, G-dur czerwone, A-dur zielone, As-dur niebieskie, Des-dur fioletowe, Es-dur różowe. Wśród współczesnych muzyków-synestetyków wymieniani są: Duke Ellington, Tori Amos, Grace Barrett, Jim Hall, Kaitlyn Hova, Billy Joel i jego córka Alexa Ray Joel, Elvin Jones i wielu innych ${ }^{97}$.

W gronie osób obdarzonych synestezyjną zdolnością widzenia i odczuwania świata znaleźli się też artyści malarze: Vincent van Gogh, Menthe Wells, Marcia Smilack, Joan Mitchell, Rosy Long i inni. Vassily Kandinsky, rosyjski malarz, grafik i teoretyk sztuki od najmłodszych lat był zafascynowany kolorami i, co znamienne, w przypadku każdego z nich odczuwał określony zapach i dźwięk ${ }^{98}$. Zapewniał, że jego doświadczenia mają charakter realnych, bezpośrednich doznań międzyzmysłowych, a nie skojarzeń metaforycznych. Od dzieciństwa w życiu Kandinsky'ego obecna była też muzyka: pobierał lekcje gry na skrzypcach i wiolonczeli. Swoje doznania wywołane dźwiękami podczas opery Ryszarda

95 Cytaty pochodzą z anonimowego artykułu w „Neuen Berliner Musikzeitung” (29 sierpnia 1895 r.), przeł. S. A. Day; podaję za: S. A. Day, http://www. daysyn.com/Synesthete-composers-and-musicians.html\#anchor_147 [dostęp: 2.02.2015].

96 Cytuję za: S. A. Day, A comparison of true-synesthete and pseudo-synesthete composers..., s. 78.

97 Patrz: strona internetowa Seana Daya poświęcona zjawisku synestezji: http://www.daysyn.com/Synesthete-composers-and-musicians.html [dostęp: 4.02.2015].

98 A. Ione, Ch. Tyler, Was Kandinsky a Synesthete?, „Journal of the History of the Neurosciences" 2003, vol. 12, No 2, s. 224. 
Wagnera Lohengrin, wystawionej w roku 1896 w Moskwie, opisał nieco później w eseju Reminiscences (1913):

The violins, the deep tones of the basses, and especially the wind instruments at that time embodied for me all the power of that pre-nocturnal hour. I saw all my colors in my mind; they stood before my eyes. Wild, almost crazy lines were sketched in front of $\mathrm{me}^{99}$.

Współodczuwanie barw i muzyki wywarło znaczący wpływ na twórczość malarską Kandinsky’ego. Jego dzieła są nasycone niezwykłą ekspresją, zdawać by się mogło - ruchem pod wpływem niesłyszalnej muzyki.

Innym ciekawym przypadkiem wpływu muzyki na sztukę malarską jest Jane Mackay, która w swym malarstwie próbuje przekazać obrazy, jakich doświadcza ,oczami umysłu” podczas słuchania muzyki (sounding art ${ }^{100}$. Przykładem może być jej praca zainspirowana II Koncertem fortepianowym f-moll op. 21 Fryderyka Chopina:

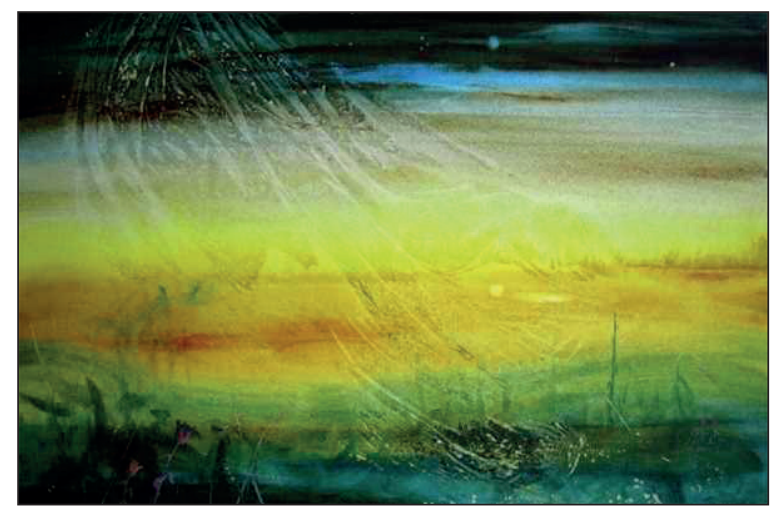

Ilustracja 6. Jane Mackay, Chopin - Piano Concerto №. 2

Źródło: http://www.soundingart.com/View.aspx?Id=506\&PageNo=8 [dostęp: 7.02.2015]

99 Podaję za: A. Ione, Ch. Tyler, Was Kandinsky a Synesthete?..., s. 224.

100 J. Mackay, Sounding Art, http://www.soundingart.com [dostęp: 3.02.2015]. 
Spośród pisarzy i poetów z darem synestezji wymieniani są: Charles Baudelaire, Theodore Hoffman, Ellen Thornetcroft Fowler, Julie Myerson, Orhan Pamuk, Jane Yardley i oczywiście Vladimir Nabokov. Arthur Rimbaud napisał sonet, w którym zaprezentował wrażenia kolorystyczne doznawane pod wpływem poszczególnych liter alfabetu:

\section{Samogloski}

A czerń, E biel, I czerwień, U zieleń, O błękity,

Tajony wasz rodowód któregoś dnia ustalę;

A, czarny i włochaty gorset lśniących wspaniale

Much, co brzęczą w odorze, cień w zatokę zaszyty;

E, blask pary, namiotów, lance w lodowatej skale,

Biali królowie, dreszcz pod baldaszkami ukryty;

I, purpura, krwi struga z ust, pięknych warg rozkwity,

Kiedy śmieją się w gniewie lub pokutniczym szale;

U, cykle, opalowa gra mórz, spokój pastwiska

Usiany zwierzętami, spokój, który odciska

W skórze uczonych czół bruzda alchemii głęboka;

O, trąba niebiańska, co dziwne świsty kołysze,

Obszary, gdzie Anioły i Świat prują ciszę:

Omego, fioletowy promieniu Jego Oka!

(przeł. Adam Ważyk)

Ciekawe doświadczenia synestezyjne towarzyszą też życiu angielskiej pisarki, autorki powieści Czekolada. O swoich niezwykłych doznaniach węchowych i o roli zapachu Joanne Harris pisze w artykule opublikowanym w „Daily Mail” ${ }^{101}$ :

To me, most scents have colours. Many colours also have scents - the brighter the colour, the stronger the scent - so that sometimes I find it difficult to separate one from the other. Perhaps this is why, in my study, there are so many brightly coloured things, and why I always like to keep my favourite perfumes alongside my books.

101 J. Harris, Joanne Harris on the power of scent, „Daily Mail”, 7.08.2010, http://www.dailymail.co.uk/home/you/article-1299986/Joanne-Harris-power-scent.html [dostęp: 4.02.2015]. 
Jane Yardley z kolei widzi barwne liczby, nazwy dni tygodnia, a cyfry przybierają w jej doznaniach cechy osobowe:

For Jane, not only do numbers and days of the week have colours, some of them have personalities as well: „So three is rather bumptious and hostile, rather sneering. Two is shy and retiring”. [...] „I don't have any problems. Except I get confusion, so if two names are the same colour, I muddle them up. I can't distinguish between the names Fiona and Catrina". When she was doing her maths A-level, algebra posed a problem, as she found it easy to mix up letters and numbers. $\mathrm{R}$ and the number two are the same colour, and three and S. I can't immediately see the difference ${ }^{102}$.

Główna bohaterka powieści Jane Yardley Painting Ruby Tuesday, Annie, została obdarzona przez autorkę darem synestezji i zdolnością widzenia (oczami umysłu) w kolorach liczb, liter, dni tygodnia, imion oraz doświadczania barwnych wzorów podczas słuchania muzyki.

Wrażenia synestezyjne obecne były też w życiu osób związanych z nauką. Laureat Nagrody Nobla w zakresie fizyki z roku 1965, Richard Feynman, posiadał zdolność barwnego postrzegania liter i liczb, o czym pisał w swojej książce What Do You Care What Other People Think?:

When I see equations, I see the letters in colors - I don't know why. As I'm talking, I see vague pictures of Bessel functions from Jahnke and Emde's book, with light-tan j's, slightly violet-bluish n's, and dark brown x's flying around. And I wonder what the hell it must look like to the students ${ }^{103}$.

Wśród innych wybitnych ludzi nauki obdarzonych tym darem znaleźli się m.in.: Eugen Bleuler - szwajcarski psychiatra, wprowadził np. terminy schizofrenia i autyzm; Geoffrey V. Chester - fizyk; Antoine Thomson d'Abbadie - francuski odkrywca, geograf, etno$\log$, lingwista i astronom.

102 Colours by numbers...

103 R. Freynman, What Do You Care What Other People Think?, W.W. Norton, New York 1988, s. 59; cytuję za: S. A. Day, Famous Synesthets, http://www. daysyn.com/Other-Synesthetes.html\#anchor_82 [dostęp: 3.02.2015]. 


\section{SYNESTEZJA W UTWORACH NABOKOVA}

\section{Nabokov i zamiłowanie do szczegółu}

Zmysłowy świat Nabokova naśladuje naturę i znajduje analogię w entomologii, która była nie tylko jego pasją, ale i natchnieniem. Poszukiwanie i opisywanie nowych odmian motyli wymagało wnikliwej obserwacji i zwracania uwagi na najdrobniejsze szczegóły, będące wyróżnikiem danego osobnika. Obserwacje dotyczyły m.in. ubarwienia skrzydeł, dźwięków wydawanych przez motyle i wydzielanych przez nie zapachów, co pisarz opisuje słowami bohatera Daru' :

Opowiadał o zapachach motyli - zapachach piżma i wanilii, o ich głosach; o przenikliwym dźwięku wydawanym przez potworkowatą gąsienicę malajskiej zmierzchnicy - wydoskonalonym mysim pisku naszej trupiej główki; o małym dźwięcznym uchu środkowym niektórych niedźwiedziówek; o sprytnym motylku z brazylijskich lasów, naśladującym świergot pewnego tamecznego ptaszka.

Warsztat pracy naukowej pisarz przenosił na twórczość literacką. W wywiadzie dla BBC (1962) wskazywał na bezpośredni związek „między pisarstwem i lepidopterologią, między precyzją

1 V. Nabokov, Dar, przeł. E. Siemaszkiewicz, posł. L. Engelking, Warszawskie Wydawnictwo Literackie MUZA SA, Warszawa 2003, s. 141. 
poezji i ekscytacją czystej nauki"2. Co więcej, umiłowanie szczegółu i dążenie do precyzji stanowiło część programu artystycznego Nabokova. Jego przeciwieństwem były poglądy Nikołaja Czernyszewskiego w powieści Dar:

Zamiłowanie do tego, co ogólne (do encyklopedii), wzgardliwa nienawiść do tego, co szczegółowe (do monografii), kazały mu właśnie zarzucać Darwinowi, że jest nie dość rzeczowy, Wallace'owi, że bzdurny (,wszystkie te naukowe specjalizacje od badania motylich skrzydełek aż po studiowanie dialektów języka Kafrów”). Sam Czernyszewski zdradzał tu jakiś niebezpieczny rozmach, jakieś rozpasane i zadufane w sobie „wszystko obleci”, rzucające wątpliwy cień na walory właśnie specjalistycznych jego prac³.

\section{I dalej:}

Czernyszewski nie odróżniał pługa od sochy; mylił piwo z maderą; nie był w stanie wymienić nazwy żadnego leśnego kwiatka oprócz dzikiej róży; znamienne jest jednak, że tę nieznajomość botaniki kompensował natychmiast „refleksją ogólną”, dodając z właściwą ignorantom pewnością siebie, że „są one (kwiaty syberyjskiej tajgi) zupełnie takie same jak te, które kwitną w całej Rosji”".

Opisując zaś innego bohatera powieści, Szyrina, Nabokov tak podkreślił jego ignorancki stosunek do świata:

Szyrin był tęgi, przysadzisty, miał rudawe, krótko przystrzyżone włosy, zawsze był źle ogolony, nosił duże okulary, poza którymi, niby w dwóch akwariach, pływały dwa małe, przejrzyste oczka, najzupełniej obojętne wobec wszystkiego, na co patrzą. Był ślepy jak Milton, głuchy jak Beethoven i głupi jak beton. Święta niespostrzegawczość (stąd zupełna niewiedza o otaczającym świecie i absolutna niezdolność do nazwania czegokolwiek) to cecha, nie wiedzieć czemu, dość częsta u przeciętnego rosyjskiego literata, jakby działał tu dobroczynny los, odmawiający wyzutemu z talentu daru zmysłowego poznania, ażeby nie paskudzić materiału. [...] Idąc teraz z Szyrinem przez park, Fiodor Konstantynowicz bezinteresownie napawał się rozśmie-

2 V. Nabokov, Strong Opinions, Vintage International, New York 1990, s. 10; również wersja on-line: http://royallib.com/read/nabokov_vladimir/Strong_opinions.html\#0 [dostęp: 3.01 .2015 ].

3 V. Nabokov, Dar..., s. 302.

${ }_{4}$ Ibidem, s. 306. 
szającą myślą, że jego towarzyszem jest głuchy ślepiec o zatkanych nozdrzach, traktujący jednak swój stan z całą obojętnością, choć czasem naiwnie utyskujący na oddalenie inteligenta od natury...5

Szczegółowość, wypracowana przy pracy naukowej nad motylami, ściśle związana jest z opisem doznań zmysłowych, o których mowa w zacytowanych wyżej słowach - wzrokowych, słuchowych, zapachowych. „Szczegół jest wszystkim” - pisał Nabokov w $A d z i e^{6}$. A do owego szczegółu zaliczał śpiew toskańskiego zniczka albo sitkańskiego mysikrólika na cmentarnym cyprysie, miętowy zapach cząbru ogrodowego lub kędzierzawca na zboczu nad brzegiem morza, roztańczony trzepot ogończyka wiązowca lub echo modraszka. Wszystko to, połączone z innymi ptakami, kwiatami i motylami, ,należy słyszeć, czuć i widzieć poprzez przezroczystość śmierci i płomiennego piękna”. Również na marginesie wydarzeń $A d y$, w odpowiedzi na zarzuty krytyków dotyczące nadmiernego - ich zdaniem - upodobania do szczegółu (określonego mianem ekstrawagancji), Nabokov napisał:

Żaden przeklęty zwolennik uogólnień, gość z półgroszowym umysłem i wyschniętą figą zamiast serca nie zdoła wyjaśnić (i to jest moja najsłodsza zemsta za całe krytykanctwo, z którym spotkało się dzieło mojego życia) indywidualnych ekstrawagancji dotyczących tych i podobnych kwestii. Żadna sztuka i żaden geniusz nie mogłyby istnieć bez takich ekstrawagancji, to ostateczne oświadczenie, pogrążające naszych błaznów i bałwanów?

W wykładach o literaturze Nabokov podkreślał, że dostrzeganie i rozkoszowanie się szczegółem powinno być udziałem dobrego czytelnika. „Nie ma nic złego - pisał - w księżycowej poświacie generalizacji, jeśli pojawia się ona wtedy, gdy już zbierzemy z wielką miłością słoneczne okruchy" " Natomiast rozpoczynanie

5 Ibidem, s. 395-396.

6 V. Nabokov, Ada albo Żar. Kronika rodzinna, przeł. L. Engelking, Warszawskie Wydawnictwo Literackie MUZA SA, Warszawa 2009, s. 94.

7 Ibidem, s. 286.

8 V. Nabokov, Wykłady o literaturze, przeł. Z. Batko, Warszawskie Wydawnictwo Literackie MUZA SA, Warszawa 2001, s. 33. 
od gotowych uogólnień jest równoznaczne z rozpoczynaniem od niewłaściwego końca i oddalaniem się od książki, zanim jeszcze zacznie się cokolwiek z niej rozumieć. Dzieło sztuki jest kreacją nowego świata, a poznanie jego szczegółów jest warunkiem jego zrozumienia.

\section{Poezja i proza}

Synestezja, rozumiana zarówno jako proces zachodzący na poziomie neuronalnym, jak i wyznacznik estetyczny, postrzegana jest często jako środek stosowany zwłaszcza w poezji. Dla Nabokova nie istniała jednak granica między poezją i prozą. Wyraźnie mówi o tym w wywiadzie dla „Playboya” (1964):

Well, poetry, of course, includes all creative writing; I have never been able to see any generic difference between poetry and artistic prose. As a matter of fact, I would be inclined to define a good poem of any length as a concentrate of good prose, with or without the addition of recurrent rhythm and rhyme?.

Fiodor Godunow-Czerdyncew, bohater Daru, poeta, noszący detale biograficzne i cechy samego autora, przybliżając rezultat swoich twórczych działań, sprowadza proces powstawania utworu poetyckiego i prozatorskiego do tych samych strategii:

Musiał jednocześnie wkładać wiele wysiłku zarówno w to, by nie stracić panowania nad grą, jak i nie zatracić poczucia gry. Strategia natchnienia i taktyka rozumu - ciało poezji i widmo przejrzystej prozy - oto określenia, które naszym zdaniem właściwie oddają charakter twórczości młodego poety ${ }^{10}$.

Uwzględnienie „taktyki rozumu” w procesie twórczym oznacza, że w powstającym tekście każde zdanie i każdy wyraz zostały dokładnie przez pisarza przemyślane i zaplanowane. Nabokov pisał, że długo i ciężko pracuje nad każdym słowem. W powieści Patrz na te Arlekiny! ustami Wadima Wadimowicza mówi, że jego

\footnotetext{
9 V. Nabokov, Strong Opinions..., s. 44.

10 V. Nabokov, Dar..., s. 16-17.
} 
„metoda doboru i melanżu słów należała do nie lada żmudnych zabiegów" "Celem pisarza było uzyskanie takiego efektu, jak ten, który został przez niego opisany w Darze $e^{12}$ :

Po przerwie [wieczoru literackiego - A. G.] ruszyli ławą poeci: wysoki młodzieniec z twarzą jak guzik, drugi bardzo niski, ale z ogromnym nosem, panienka, ktoś niemłody w pince-nez, znów panienka, znów młody, wreszcie Konczejew, który w przeciwieństwie do zwycięskiej, metalicznej dobitności innych cicho i mdło wymamrotał swoje wiersze, lecz w tych wierszach samoistnie żyło tyle muzyki, w niejasnym na pozór wersie rozwierała się taka otchłań znaczeń, tak ufało się dźwiękom i tak było zdumiewające, że oto z tych samych słów, które nanizywali wszyscy, nagle powstawała, przelewała się i znikała, nie nasyciwszy do końca pragnienia, jakaś niepodobna do słów, niepotrzebująca słów samorodna doskonałość, że po raz pierwszy w ciągu wieczoru oklaski były nieobłudne.

Podobnie jak Fiodor Godunow-Czerdyncew, ,ucząc się celności słowa i maksymalnej czystości związków słownych, doprowadzał przejrzystość prozy do jambu, a potem go przełamywał"13. W rezultacie uzyskiwał „układ słów niemożliwych do zastąpienia i nieprzesuwalnych"14.

O tym, jaki powinien być utwór poetycki i co go powinno wyróżniać, Nabokov mówi, znów odwołując się do przykładu wierszy Fiodora Godunowa-Czerdyncewa:

Cóż można powiedzieć o formalnej stronie jego wierszy? Są to oczywiście miniatury, ale wykonane z tym niebywale subtelnym mistrzostwem, kiedy wyraźnie widać każde pociągnięcie, nie dlatego, że wszystko wyszło spod zbyt kaligraficznego pędzla, lecz dlatego że rzetelność i niezawodność talentu, gwarantującego, iż autor dotrzyma wszystkich punktów artystycznej umowy, mimowolnie sugeruje czytelnikowi obecność najdrobniejszych szczegółów. [...] Każdy jego wers tęczuje jak arlekin. Kto ceni w poezji maksymalnie nasyconą malowniczość, polubi ten tomik ${ }^{15}$.

11 V. Nabokov, Patrz na te Arlekiny!, przeł. A. Kołyszko, posł. L. Engelkinga, Warszawskie Wydawnictwo Literackie MUZA SA, Warszawa 2005, s. 97.

12 V. Nabokov, Dar..., s. 120.

13 Ibidem, s. 124.

14 Ibidem, s. 176.

15 Ibidem, s. 37. 
Skoro proza utożsamiana jest z poezją, a poezja - z dziełem malarskim, malowniczość i nastawienie na jak największą precyzję i szczegółowość stają się naturalną konsekwencją tych zależności. I tak jak artysta sztuk pięknych maluje obraz, uwzględniając niuanse cienia i światła, barw i ich odcieni, tła i postaci, tak i pisarz posługuje się słowem, dokładnie nazywając każdy blask, kolor, cień, każdy dźwięk, smak i dotyk, który ma się stać udziałem czytelnika, by mógł przeniknąć do świata przedstawionego w tekście i ,wejść w głąb malowidła”, jak opisuje to McGore w opowiadaniu La Veneziana ${ }^{16}$. Można zatem powiedzieć, że proza Nabokova świadomie i nieustannie wykorzystuje środki poetyckie, aby podkreślić, wzbogacić i uintensywnić ekspresywne właściwości języka. Przedmioty i zjawiska ulegają przekształceniom zaostrzonym dzięki synestezji. Również metaforyzacja Nabokova opiera się na jednoczesnych bądź kolejno po sobie następujących aktualizacjach węchowych, dotykowych, słuchowych i wzrokowych aspektów rzeczywistości oraz na przejściach między biegunami uprzedmiotowienia i ożywienia ${ }^{17}$.

\section{Barwy i dźwięki}

W autobiograficznej książce Pamięci, przemów! Autobiografia raz jeszcze Nabokov tak pisze o swoim pierwszym zapamiętanym doświadczaniu świata barw i o roli matki w kształtowaniu u niego wrażliwości na świat doznań zmysłowych ${ }^{18}$ :

${ }_{16}$ V. Nabokov, La Veneziana, [w:] V. Nabokov, List, który nigdy nie dotart do Rosji i inne opowiadania, t. I, przeł. M. Kłobukowski i L. Engelking, Warszawskie Wydawnictwo Literackie MUZA SA, Warszawa 2007, s. 161-162.

17 Por.: М. Медарич, Владимир Набоков и роман XX столетия, [w:] Д. К. Бурлака (ред.), В. В. Набоков: pro et contra, Издательство Русского Христианского гуманитарного института, Санкт-Петербург 1997, s. 470.

18 V. Nabokov, Pamięci, przemów! Autobiografia raz jeszcze, przeł. A. Kołyszko, Warszawskie Wydawnictwo Literackie MUZA SA, Warszawa 2004, s. 32. 
Matka zrobiła wszystko, żeby rozbudzić moją ogólną wrażliwość na bodźce wizualne. Ileż akwarel dla mnie namalowała! Cóż to było za objawienie, kiedy pokazała mi drzewo bzu, które wyrasta z mieszaniny błękitu i czerwieni! Czasem w naszym petersburskim domu wyjmowała z tajnej skrytki w ścianie swojej garderoby (a zarazem pokoju moich narodzin) stos kosztowności, żebym pobawił się przed zaśnięciem. Byłem wtedy bardzo mały, toteż w moim odczuciu owe mieniące się tiary, naszyjniki i pierścionki nie ustępowały pod względem tajemniczości i czaru iluminacji w mieście podczas carskich fet, kiedy w watowanym bezruchu mroźnej nocy jarzyły się gigantyczne monogramy, korony oraz inne wzory herbowe ułożone z kolorowych żarówek - szafirowych, szmaragdowych, rubinowych - płonących z uroczą dyskrecją nad ośnieżonymi gzymsami fasad przy ulicach mieszkalnych.

Do wspomnień związanych z wrażeniami, jakie wywołały u niego kosztowności ze szkatułki matki, pisarz powraca w słowach Fiodora Godunowa-Czerdyncewa, bohatera Daru, który próbuje przybliżyć swojemu rozmówcy (Konczejewowi) synestezyjne doznania barw i odcieni liter:

[...] oceniłby pan też zapewne moje połyskliwe „s”, gdybym mógł zsypać panu w dłon jasne szafiry, których dotykałem jako drżące i nic nierozumiejące dziecko, kiedy moja matka w balowej sukni, głośno szlochając, wysypywała swoje niebiańskie klejnoty z otchłani na dłoń, ze szkatułek na aksamit i nagle wszystkie je z powrotem zamykała i nie jechała nigdzie, nie bacząc na gniewne już namowy swojego brata [...], kiedy już w bocznym oknie odsunęło się zasłonę, można było zobaczyć w granatowej czerni nocy wzdłuż ciągnących się nabrzeżem fasad zdumiewająco nieruchome, groźne, diamentowe monogramy i kolorowe wieńce... - Słowem, Buchstaben von Feuer... ${ }^{19}$

Matka stała się dla małego Wołodii pierwszą nauczycielką malarstwa i pierwszą przewodniczką w świecie barw. Warto wspomnieć na marginesie, że owe wrażenia połysku i blasku kamieni szlachetnych znajdą swój wyraz w niemal każdym tekście prozy Nabokova.

Spektrum barw to motyw, do którego pisarz często powraca też $\mathrm{w}$ innych fragmentach swojej autobiografii. W czasach rosyjskiego

19 V. Nabokov, Dar..., s. 96-97. 
dzieciństwa panna Robinson, jedna z zatrudnionych przez Nabokowów guwernantek, pokazała dzieciom zabawę, która polegała na wyszukiwaniu na ziemi i układaniu na wielkim arkuszu papieru różnokolorowych liści klonu. W rezultacie powstawało niemal pełne widmo, z wyjątkiem błękitu: ,zieleń przechodziła w cytrynowy, cytrynowy w pomarańczowy i tak dalej przez czerwienie do fioletów, fioletowych brązów, ponownie czerwieni i z powrotem przez cytrynowy do zieleni"20.

Kolorystyczne spektrum pojawia się też w odniesieniu do pudełka kredek, których zawartość nigdy nie była zgodna z widmem reklamowanym na opakowaniu. Jak wspomina Nabokov ${ }^{21}$, zieloną kredką można było wyczarować ,zmierzwione drzewo lub wir powstały po zanurzonym krokodylu”, niebieska rysowała „horyzont wszystkich mórz", a tępa kredka nieokreślonego koloru ciągle zawadzała. Brązowa, podobnie jak czerwona, zawsze była złamana, choć określony sposób trzymania luźnego czubka umożliwiał dalsze rysowanie. Mała fioletowa, faworytka chłopca, była „zużyta do takiego ogryzka, że ledwo się ją dało utrzymać w palcach". Jedynie „biała, chuda albinoska zachowywała pierwotną długość” dopóki Wołodia nie odkrył, że „nie jest bynajmniej oszustką, która nie pozostawia śladu na kartce, lecz idealnym wprost przyborem”, gdyż rysując nią mógł sobie wyobrażać, co tylko chciał²2.

20 V. Nabokov, Pamięci, przemów..., s. 87.

21 Ibidem, s. 90.

${ }^{22} \mathrm{~W}$ rosyjskojęzycznej wersji autobiografii Nabokov podaje nieco inny zestaw kredek i wykonywanych nimi rysunków niż w wersji angielskojęzycznej, na podstawie której powstało zacytowane wyżej tłumaczenie: „Лиловый карандаш стал так короток от частого употребления, что его трудно держать. Синий проводит горизонт любого моря. Голубой ужасно ломок: его шатающийся молочный кончик подпирается выступом выщепки. Зеленый спиральным движением производит липу - или дым из домишки, где варят шпинат. Желтый безнадежно сломан. Оранжевый создает солнце, садящееся за морской горизонт. Красный малыш едва ли не короче лилового. Из всех карандашей только белый сохранял свою девственную длину - пока я не догадался, что этот альбинос, будто бы не оставляющий следа на бумаге, на самом деле орудие идеальное, ибо, водя им, можно было вообразить незримое запечатление настоящих, взрослых картин, без вмешательства собственной младен- 
Jeden z ciekawszych opisów barw tęczowego spektrum zawarty też został we wspomnieniach czasu spędzanego na werandzie, gdzie dzieci słuchały czytanych ,rzadkim kryształem rytmicznego głosu Mademoiselle" książek ${ }^{23}$ :

[...] źródłem zauroczenia podczas tych sesji czytania był arlekinowy deseń kolorowych szybek wstawionych w bielone framugi z obu stron werandy. Ogród widziany przez te magiczne szkiełka stawał się dziwnie nieruchomy i oddalony. Jeżeli patrzyło się przez niebieskie szkło, piasek obracał się w popiół, a po tropikalnym niebie płynęły atramentowe drzewa. Żółte tworzyło bursztynowy świat przesycony wyjątkowo mocnym wywarem blasku słońca. Czerwone kazało liściom skapywać ciemnym rubinem na różową ścieżkę. Zielone nasączało zieleń jeszcze zieleńszą zielenią.

Przez wiele kolejnych lat Wołodia pobierał lekcje rysunku i malarstwa od mniej lub bardziej znanych i utalentowanych nauczycieli wspomnianych w autobiografii: Cummingsa - mistrza zachodów słońca, Jaremicza - łączącego rozmaite dziedziny sztuki, Dobużyńskiego - który zwracał uwagę na najdrobniejsze szczegóły malowanych obiektów, odtwarzane z pamięci ${ }^{24}$. Wprawdzie Nabokov nie zyskał sławy jako artysta malarz, ale techniki malarskie i dbałość o szczegół przenosił na płaszczyznę literatury. Bezpośrednio odwoływał się do nich, na przykład, opisując ogród, po którym przechadzał się ojciec Fiodora Konstantynowicza w Darze:

Jeśli w alei, pod stopami, falowały pierścienie gorącego światła, to w oddali nieodmiennie przebiegało poprzeczne, szerokie, aksamitne pasmo, za nim widniało oranżowe sito, dalej zaś, już zupełnie w głębi, trwała gęsta, żywa czerń, która, gdy ją malowano, zadowalała oko akwarelisty jedynie dopóty, dopóki farby nie wyschły, aby więc utrzymać piękno - w jednej chwili umierające - należało nakładać warstwę na warstwę²5.

ческой живописи. - В. В. Набоков, Другие берега, [w:] Владимир Набоков. Собрание сочинений в четырех томах, ред. В. В. Ерофеев, т. 4, Издательство «Правда», Москва 1990, s. 188.

${ }_{23}$ V. Nabokov, Pamięci, przemów..., s. 94-95.

24 Ibidem, s. 79-81.

25 V. Nabokov, Dar..., s. 101. 
Innym razem z kolei, opisując proces powstawania powieści w jego umyśle i przenoszenia jej na papier, powołuje się na podobny proces tworzenia dzieła malarskiego:

After the first shock of recognition - a sudden sense of ,this is what I'm going to write" - the novel starts to breed by itself; the process goes on solely in the mind, not on paper; and to be aware of the stage it has reached at any given moment, I do not have to be conscious of every exact phrase. [...] I know that the details are there already, that in fact I would see them plainly if I looked closer, if I stopped the machine and opened its inner compartment; but I prefer to wait until what is loosely called inspiration has completed the task for me. There comes a moment when I am informed from within that the entire structure is finished. All I have to do now is take it down in pencil or pen. Since this entire structure, dimly illuminated in one's mind, can be compared to a painting, and since you do not have to work gradually from left to right for its proper perception, I may direct my flashlight at any part or particle of the picture when setting it down in writing ${ }^{26}$.

Wrażliwość na doznania wzrokowe nie jest jednak jedyną sferą doświadczeń zmysłowych, które w życiu i twórczości Nabokova odegrały decydującą rolę w recepcji świata zewnętrznego i w kształtowaniu stylu pisarskiego. W autobiografii przyznaje, że w przeciwieństwie do doświadczeń matki, Jeleny Iwanowny, dźwięk nie powodował u niego doznań kolorystycznych:

Odkryliśmy [...] że niektóre jej litery mają to samo zabarwienie, co moje, a ponadto, że nuty również kojarzą jej się optycznie. We mnie nie wywołują one żadnych reakcji chromatycznych. Z żalem stwierdzam, że muzyka działa na mnie wyłącznie jako przypadkowy ciąg mniej lub bardziej irytujących dźwięków. W pewnych okolicznościach emocjonalnych mogę znieść spazmy zawodzących skrzypiec, wszelako fortepian i wszystkie instrumenty dęte nudzą mnie w małych dawkach, a obdzierają ze skóry w większych. Mimo licznych oper, na które prowadzano mnie co roku zimą [...], moją słabą wrażliwość na muzykę przesłoniła ze szczętem wizualna udręka, iż nie mogę czytać Pimenowi przez ramię, albo daremne próby wyobrażenia sobie zawisaków w mrocznym kwieciu ogrodu Julii27.

26 V. Nabokov, Strong Opinions..., s. 31-32.

27 V. Nabokov, Pamięci, przemów..., s. 31. 
Oboje rodzice pisarza mieli słuch absolutny ${ }^{28}$. Ojciec, $\mathrm{z}$ trwającego przez całe życie zamiłowania do opery, w latach 1880-1922 słyszał niemal wszystkich liczących się śpiewaków europejskich. Chociaż nie umiał grać na żadnym instrumencie, pamiętał każdy dźwięk ulubionych oper. Brat stryjeczny pisarza, Nikołaj Dmitriewicz Nabokow, został kompozytorem - zresztą nie pierwszym: w linii rodowej ze strony pradziadka barona Ferdynanda von Korff pojawia się nazwisko znanego kompozytora niemieckiego Carla Heinricha Grauna ${ }^{29}$. Syn pisarza, Dmitrij, również wyróżniał się słuchem muzycznym i głosem zapowiadającym karierę śpiewaka. Jak Nabokov pisał w autobiografii, wibrująca struna muzykalnych genów, która go ominęła, prowadzi przez ojca od szesnastowiecznego organisty Wolfganga Grauna aż do jego syna ${ }^{30}$. Tym boleśniej więc odczuwał nie tylko brak zdolności muzycznych i jakichkolwiek predyspozycji w tym kierunku, ale też deficyt wiedzy:

I have no ear for music, a shortcoming I deplore bitterly. When I attend a concert - which happens about once in five years - I endeavour gamely to follow the sequence and relationship of sounds but cannot keep it up for more than a few minutes. Visual impressions, reflections of hands in lacquered wood, a diligent bald spot over a fiddle, these take over, and soon I am bored beyond measure by the motions of the musicians. My knowledge of music is very slight; and I have a special reason for finding my ignorance and inability so sad, so unjust: There is a wonderful singer in my family - my own son. His great gifts, the rare beauty of his bass, and the promise of a splendid career - all this affects me deeply, and I feel a fool during a technical conversation among musicians. I am perfectly aware of the many parallels between the art forms of music and those of literature, especially in matters of structure, but what can I do if ear and brain refuse to cooperate? I have found a queer substitute for music in chess - more exactly, in the composing of chess problems ${ }^{31}$.

Nabokov wprawdzie nie komponował ani nie rozkoszował się słuchaniem klasyków muzyki poważnej, ale jego teksty przesycone

28 Patrz: В. В. Набоков, Другие берега..., s. 147.

29 Patrz: V. Nabokov, Pamięci, przemów..., s. 48.

30 Ibidem, s. 162.

31 V. Nabokov, Strong Opinions..., s. 35. 
są określeniami dźwięków, tonów, szmerów i ciszy. Co więcej, ustami bohatera Daru wyraża pragnienie napisania takiej prozy, ,w której by się myśl i muzyka tak złożyły, jak fałdy życia we śnie"32. Nie tylko znajdował podobieństwa między formami muzycznymi i literackimi, jak o tym wspomniał w zacytowanym wyżej fragmencie wywiadu, ale też sam proces tworzenia tekstu opisał w kategoriach barw i terminologii muzycznej:

Już od początku obraz książki - jej tonacja i ogólny zarys - rysował mu się niezwykle wyraziście, miał uczucie, że dla każdego wyszperanego drobiazgu istnieje przygotowane już miejsce i że nawet praca nad wyławianiem materiałów ma barwę przyszłej książki, tak jak morze rzuca granatowy blask na rybacką łódź, a owa łódź odbija się w wodzie wraz z tym poblaskiem ${ }^{33}$.

Przesadzone wydają się też zapewnienia autora Lolity o tym, że pozostaje niewrażliwy na dźwięki, tym bardziej gdy przypomnimy słowa bohatera opowiadania, w którym odgłosy świata zajmują tytułową pozycję:

Это было счастливое чувство [...]. Оно было потому счастливое, что лилось гармонично. Оно было счастливое, как всякое движение, излученье. Был я когда-то раздроблен на миллионы существ и предметов, теперь я собран в одно, завтра раздроблюсь опять. И все в мире переливается так. В тот день я был на вершине волны, знал, что все вокруг меня - ноты одной гармонии, знал - втайне - как возникли, как должны разрешиться собранные на миг звуки, какой новый аккорд вызовет каждая из разлетавшихся нот. В гармонии не может быть случайности. Музыкальный слух души моей все знал, все понимал ${ }^{34}$.

Nie brak też odniesień muzycznych w opisach dźwięków należących do otaczającego świata. Nabokov pisze o pociągu elek-

32 V. Nabokov, Dar.., s. 92.

33 Ibidem, s. 250.

${ }^{34}$ В. В. Набоков, Звуки, [w:] В. В. Набоков, Полное собрание рассказов, составление текста и примечания - А. Бабиков, Изд. «Азбука-Аттикус», Санкт-Петербург 2013, s. 34-35. 
trycznym, który ,przeciągnął smyczkiem po basowej strunie" 35 ; o harfach deszczu, które pewnej kwietniowej nocy ,podniecająco mamrotały w kanale orkiestry" ${ }^{36}$. W rozmowach Vana z Adą, z kolei, pojawia się stała fraza „And do you remember”, zawsze z implikowaną codettą ,and" wprowadzającą koralik, który należało nawlec na zerwany sznurek naszyjnika ${ }^{37}$. W opowiadaniu Czas i zmierzch zbliżający się do kresu życia dziewięćdziesięcioletni Arthur Freeman wyznaje, że ,nie potrafi stłumić romantycznej nuty, która przynależy do symfonii przeszłości"38.

Wzajemne przenikanie się wrażeń dźwiękowych i dotykowych znalazło natomiast wyraz w opublikowanym w roku 1951 wierszu Nabokova pt. Voluptates Tactionum ${ }^{39}$ :

Some inevitable day

On the editorial page

Of your paper it will say,

„Tactio has come of age".

When you turn a knob, your set

Will obligingly exhale

Forms, invisible and yet

Tangible - a world in Braille.

Think of all the things that will

Really be within your reach!

Phantom bottle, dummy pill,

Limpid limbs upon a beach.

Grouped before a Magnotack,

Clubs and families will clutch

Everywhere the same compact

Paradise (in terms of touch).

35 V. Nabokov, Dar..., s. 404.

36 V. Nabokov, Rozpacz, przeł. L. Engelking, Wydawnictwo ATEXT, Gdańsk 1993, s. 33.

37 V. Nabokov, Ada albo Żar..., s. 109.

38 V. Nabokov, Czas i zmierzch, [w:] V. Nabokov, Kęs życia i inne opowiadania, t. II, przeł. L. Engelking..., s. 552.

39 V. Nabokov, Poems and Problems, McGraw Hill, New York 1970, s. 166. 
Palpitating fingertips

Will caress the flossy hair

And investigate the lips

Simulated in midair.

See the schoolboy, like a blind

Lover, frantically grope

For the shape of love - and find

Nothing but the shape of soap.

Na wyjątkową zdolność odczuwania smaku i dotyku wskazują wspomnienia Nabokova z wczesnych lat jego dzieciństwa:

Wspomnienie mego łóżeczka, z jego siateczką z bawełny po bokach, kojarzy mi się z pewnym, pięknie wykonanym z czarnego szkła jajkiem pozostałym po jakiejś niezapamiętanej Wielkiej Nocy. Zwykłem posysać rożek prześcieradła aż stawał się wilgotny, by owijać nim jajko ściśle, a potem zlizywać zeń ciepło pozostawione przez ten wilgotny okład na lśniącej niezwykłym kolorem powierzchni ${ }^{40}$.

Z kolei w innym miejscu autobiografii, opisującym ulubione zajęcie matki Wołodii, a mianowicie wyprawę na grzybobranie, wrażenia wzrokowe (również kolorystyczne) mieszają się z zapachowymi, smakowymi i dotykowymi

Do największych przyjemności matki latem należała z gruntu rosyjska rozrywka: chodzenie na grzyby. Jej pyszne znaleziska, smażone na maśle i doprawione śmietaną, zjawiały się u nas regularnie na kolacyjnym stole. Ale względy smakowe nie były tu najważniejsze. [...] szukała tylko gatunków należących do jadalnych odmian borowików (takich jak bułany prawdziwek, brązowy podbrzeźniak, czerwony kozak oraz kilku bliskich krewniaków), zwanych mylnie przez niektórych truflami, a przez mikologów definiowanych chłodno jako grzyby ziemne, mięsiste, gnilne, o centralnym trzonie. Ich zwięzłe kapelusze - przyległe u osobników młodych, krzepkie i kusząco półkoliste u dojrzałych - są gładkie (a nie blaszkowate) od spodu i stoją na kształtnej, jędrnej nodze. [...] Deszcze powodowały obfity wysyp owych cudów pod jodłami, brzozami i osikami w naszym parku, zwłaszcza w starszej

${ }^{40}$ B. Boyd, Nabokov. Dwa oblicza, opracował i przełożył W. Sadkowski, Wydawnictwo Książkowe Twój Styl, Warszawa 2006, s. 42. 
części. [...] W jego cienistych zakamarkach unosił się ów szczególny borowikowy zapach, który rozdyma nozdrza Rosjan - ciemny, wilgotny, miły bukiet woni wilgotnego mchu, żyznej gleby, butwiejących liści. [...] Nieraz pod koniec deszczowego dnia słońce tuż przed zachodem rzucało blady blask, i tam, na tym wilgotnym okrągłym stoliku, leżały jej grzyby, mieniące się kolorami, czasem noszące ślady innych roślin - a to źdźbło trawy przylgnęło do lepkiego, płowego kapelusza, a to mech nadal otulał bulwiastą podstawę ciemno nakrapianej nogit1.

Doświadczane wrażenia towarzyszące zbieraniu grzybów zostały w tekście zestawione niejako obok siebie, a więc nie spełniają kryteriów synestezji w znaczeniu zjawiska zachodzącego na poziomie neuronalnym. Jest tu smak smażonych grzybów, następnie kolory i kształt odmian borowików, zapach w grzybowym zaułku z domieszką odczuć dotykowych, i znów wrażenia barw pod wpływem promieni zachodzącego słońca. Na szczególną uwagę zasługuje jednak połączenie doznań koloru, zapachu i dotyku (barwny dotykowy zapach): ,ciemny, wilgotny, miły bukiet woni wilgotnego mchu, żyznej gleby, butwiejących liści”, które z całą stanowczością można nazwać synestezyjnym.

Muzyka i dźwięki, obok barw, tworzą zatem ważną płaszczyznę wielowarstwowego świata Nabokova. Zarówno same w sobie, jak i w połączeniu z innymi elementami doświadczeń zmysłowych, nadają wrażenie harmonii, całości, wielowymiarowości. Dopełnione przez opisy doznań smakowych, zapachowych i dotykowych, sprawiają, że czytelnik zaczyna odczuwać, tak samo jak bohaterowie, stając się częścią świata opowiadań i powieści. W tym miejscu trzeba zaznaczyć, że źródła opisywanych doznań sięgają osobistych doświadczeń autora. W wywiadzie udzielonym dla telewizji BBC w roku 1962, na pytanie Petera Duvala Smitha i Christophera Burstalla dotyczące roli pamięci i wspomnień z wczesnych lat dzieciństwa w twórczości pisarskiej, Nabokov odpowiedział:

Memory is, really, in itself, a tool, one of the many tools that an artist uses; and some recollections, perhaps intellectual rather than emotional, are very

${ }^{41}$ V. Nabokov, Pamięci, przemów. Autobiografia raz jeszcze..., s. 37-39. 
brittle and sometimes apt to lose the flavor of reality when they are immersed by the novelist in his book, when they are given away to characters. [...] But, for instance - oh, I don't know, the freshness of the flowers being arranged by the under-gardener in the cool drawing-room of our country house, as I was running downstairs with my butterfly net on a summer day half a century ago: that kind of thing is absolutely permanent, immortal, it can never change, no matter how many times I farm it out to my characters, it is always there with me; there's the red sand, the white garden bench, the black fir trees, everything, a permanent possession ${ }^{42}$.

Również w autobiografii podkreślił wagę swych wspomnień i wartość najwcześniejszych doznań zmysłowych:

Jakiż mały jest kosmos (zmieściłby się w torbie kangurzycy), jakiż wątły i lichy w porównaniu z ludzką świadomością, z jednym naszym wspomnieniem i jego ujęciem w słowach! Być może przesadnie hołubię swoje najwcześniejsze wrażenia, ale też mam powody do wdzięczności. Doprowadziły one do istnego edenu doznań wizualnych i dotykowych ${ }^{43}$.

Co więcej, zgodnie ze słowami Arthura Freemana, bohatera opowiadania Czas i zmierzch (Time and Ebb), z większą siłą odciskają się w pamięci doznania zmysłowe i emocjonalne towarzyszące wydarzeniom niż związane z nimi szczegóły dotyczące miejsca czy czasu:

Nie jestem w stanie bez sprawdzenia podać, w którym roku Sekcja Embriologiczna Towarzystwa Miłośników Przyrody w Rejkiawiku wybrała mnie na członka-korespondenta, ani kiedy dokładnie Amerykańska Akademia Nauk przyznała mi swoją najwyższą nagrodę (pamiętam jednak wielką przyjemność, jaką sprawiły mi oba te wyróżnienia) ${ }^{44}$.

Powyższe słowa upoważniają nas do przyjęcia założenia, że doznania bohaterów powieści i opowiadań są doznaniami obecnymi w pamięci Nabokova. To z kolei prowadzi do graniczącego

\footnotetext{
42 V. Nabokov, Strong Opinions..., s. 12.

43 V. Nabokov, Pamięci, przemów..., s. 21.

44 V. Nabokov, Czas i zmierzch..., s. 544.
} 
z pewnością stwierdzenia, że przedstawiane w tekstach wrażenia o charakterze synestezyjnym wynikają z doświadczeń autora zgromadzonych w jego wspomnieniach. Obserwacja rodzajów owych doznań oraz sposobów ich projekcji przekazywanych za pośrednictwem bohaterów utworów przybliżyć nas może do takiego świata wrażeń zmysłowych, jaki był udziałem Nabokova.

\section{Odmiany nabokovowskiej synestezji}

W Adzie Nabokov wyznał: „Sounds have colors, colors have smells" "45. Jednakże barwy dźwięków i zapach kolorów to tylko dwie z możliwych kombinacji doznań sensorycznych, które pojawiają się w twórczości autora Lolity. Ich różnorodność przedstawiają przykłady przedstawione i omówione w poniższych grupach. Punktem wyjścia klasyfikacji były doznania zmysłowe, które stanowią źródło dla wrażeń synestezyjnych, związane kolejno z widzeniem, słyszeniem, dotykaniem, smakiem, zapachem oraz z doświadczaniem temperatury i bólu.

\section{Doznania związane z widzeniem}

barwa - synestezyjny smak

Odczuwanie smaku pod wpływem ujrzanego koloru jest udziałem głównego bohatera Daru, powieści, jak pamiętamy, noszącej znamiona książki autobiograficznej. Po przeprowadzce do nowego pensjonatu Fiodor Godunow-Czerdyncew przechadza się wzdłuż ulicy, szukając bodźców zmysłowych dla swoich doświadczeń:

Опытным взглядом он искал в ней [w ulicy miasta przed zamieszkaniem w budynku przy niej A. G.] того, что грозило бы стать ежедневной зацепкой, ежедневной пыткой для чувств, но, кажется, ничего такого не намечалось, а рассеянный свет весеннего серого дня был не только вне подозрения, но еще обещал умягчить иную мелочь, которая в яркую

45 V. Nabokov, Ada or Ardor: A Family Chronicle..., s. 419. 
погоду не преминула бы объявиться; все могло быть этой мелочью: цвет дома, например, сразу отзывающийся во рту неприятным овсяным вкусом, а то и халвой; деталь архитектуры, всякий раз экспансивно бросающаяся в глаза... ${ }^{46}$

Fiodor wyraźnie mówi o kolorze domu, który od razu wzbudza w ustach niemiły posmak owsianki lub chałwy. Prawdopodobnie nie chodzi tu o konkretną barwę, powodującą opisane odczucia w każdych okolicznościach. Barwa taka zresztą nigdzie ani w tym, ani w innym tekście Nabokova nie została nazwana. A ponieważ i chałwa, i owsianka są kolorystycznie do siebie zbliżone, możemy przypuszczać, że ich barwa została przeniesiona na dostrzeżony przez Fiodora dom. O trafności takiej interpretacji przekonują też dalsze poszukiwania detalu, który mógłby być „,codzienną torturą dla zmysłów”: mógłby się nim stać również ,запах, отказавшийся в последнюю секунду сообщить воспоминание, о котором был готов, казалось, завопить, да так на углу и оставшийся - самой за себя заскочившею тайной" 47 . Zapach nasuwał skojarzenie z jakimiś przykrymi wspomnieniami, o których bohater Nabokova wolałby nie pamiętać. Podobnie kolor domu, przypominający owsiankę bądź chałwę, przeniósł go do czasów dzieciństwa, przypomniawszy smak niezbyt lubianych potraw. Wydawać się więc może, iż mamy tu do czynienia nie z synestezją polegającą na scaleniu doznań należących do różnych zmysłów (barwa i smak), lecz raczej z pozorną w naszym rozumieniu synestezją zestawiającą obok siebie różne doznania zmysłowe. Uzasadnieniem dla potraktowania barwy o smaku chałwy czy owsa w kategoriach doznań międzymodalnych będzie jednak rola pamięci i wspomnień w kształtowaniu doznań synestezyjnych, o której mówiliśmy wcześniej.

Powyższy przykład nie jest jedynym przypadkiem doznawania smaku pod wpływem barw lub światła przez bohaterów Na-

46 V. Nabokov, Дар, [w:] В. В. Набоков, Полное собрание рассказов, составление текста и примечания - А. Бабиков, Изд. «Азбука-Аттикус», Санкт-Петербург 2013, s. 6.

47 Ibidem. 
bokova. W Zaproszeniu na egzekucję Cyncynat z adwokatem i strażnikiem podążają wzdłuż ciemnego więziennego korytarza, w którym mrok rozprasza 'gorzkie światło': „Кое-где надо было включить электричество; горьким, желтым огнем загоралась пыльная лампочка, вверху или сбоку"48. Z kolei w Darze w opisie ciasnego pomieszczenia o prowincjonalnym charakterze, w którym gościli nudni goście, na kanapie leżą poduszki w nieapetycznych barwach:

На диване, среди подушек - все неаппетитных, заспанных цветов - подле шелковой куклы с бескостными ногами ангела и персидским разрезом очей, которую оба сидящих поочередно мяли, удобно расположились: огромный, бородатый... ${ }^{49}$

barwa - synestezyjny dźwięk

Stosunkowo rzadko w tekstach pojawia się opis synestezyjnego dźwięku odnoszącego się do barw, który wykracza poza ramy metafory literackiej. Reprezentującym to zjawisko przykładem może być opis pokrytego śniegiem górskiego stoku w opowiadaniu Cios skrzydta: ,люди в ярких шарфах пили крепкий чай, готовые снова лететь на мороз, на скаты, что гудящим блеском били в широкие стекла"

barwa - synestezyjny dotyk

'Lepkość światła / barwy' jest tym wrażeniem, które jest doświadczane przez bohaterów kilku utworów Nabokova. W Zaproszeniu na egzekucje , липкая от луны водяная гладь" ${ }^{51}$ sugeruje, że światło księżyca ma w sobie lepkość i nadaje ją powierzchniom,

48 В. В. Набоков, Приглашение на казнь, [w:] В. В. Ерофеев (ред.), Владимир Набоков. Собрание сочинений в четырех томах, т. 4, Издательство «Правда», Москва 1990, s. 23.

49 В. В. Набоков, Дар..., s. 30-31.

50 В. В. Набоков, Удар крыла, [w:] В. В. Набоков, Полное собрание рассказов.., s. 56.

51 В. В. Набоков, Приглашение на казнь..., s. 14. 
na które pada. Tytułowa bohaterka $A d y$ przyciąga uwagę Vana swymi rozchylonymi w uśmiechu, lepko błyszczącymi ustami: „Her plump, stickily glistening lip smiled" 52 . Fred w opowiadaniu Kartoflany Elf śni o dawnym cyrkowym życiu i w owych snach dusi się zamknięty w kleistym półmroku: „он слышал сквозь стенки певучий, равнодушный голос Шока и не мог найти люк в полу, задыхался в клейком сумраке..." 53

'Kłujący granat' określa w Darze kolor włosów Marianny Nikołajewny, który pojawia się w opisie licznych barwnych detali jej aparycji:

[...] а Марианна Николаевна убирала со стола. Ее полное, темно-розовое лицо, с лоснящимися закрутками ноздрей, лиловые брови, абрикосовые волосы, переходящие в колючую синеву на голом, жирном загривке, васильковое око, с засоренным ресничной краской лузгом, мимоходом окунувшее взгляд в опивочную тину на дне чайника, кольца, гранатовая брошь, цветистый платочек на плечах, - все это составляло вместе грубо, но сочно намалеванную картину, несколько заезженного ханра ${ }^{54}$.

kolor - synestezyjna temperatura

Określenie 'synestezyjna temperatura' obejmuje wszelkie określenia stanu cieplnego wynikającego z doświadczania pewnych wrażeń sensorycznych. Trzeba przyznać, że tego rodzaju doznania nie należą do tych wrażeń synestezyjnych, które znajdują swój wyraz w prozie Nabokova. Wśród zgromadzonych przykładów zaledwie jeden może być rozpatrywany w kategoriach międzymodalnego doświadczania temperatury barwy:

Теперь (в этом белом, освещенном загончике, при золотистой близости Зины и при участии теплой вогнутой темноты, сразу за вырезным озарением петуний) он окончательно нашел в мысли о методах судьбы то, что служило нитью, тайной душой, шахматной идеей для едва еще задуманного «романа», о котором он накануне вскользь сообщал матери 55 .

52 V. Nabokov, Ada or Ardor: A Family Chronicle..., s. 75.

53 В. В. Набоков, Картофельныий Эльф, [w:] В. В. Набоков, Полное собрание рассказов..., s. 113.

54 В. В. Набоков, Дар..., s. 316.

55 Ibidem, s. 327. 
Liczną grupę stanowią natomiast synestezyjne metafory literackie łączące doznania zmysłowe $\mathrm{z}$ określeniami związanymi $\mathrm{z}$ temperaturą, przedstawione $\mathrm{w}$ rozdziale 4 .

\section{Doznania związane ze słyszeniem}

dźwięk - synestezyjny kolor

Kolor dźwięku łączy w sobie skojarzenia związane z dwiema pasjami Nabokova: $\mathrm{z}$ rozwijanym i zaspokajanym zamiłowaniem do barw i malarstwa oraz z niespełnionym pragnieniem posiadania talentu muzycznego i swobodnego poruszania się w świecie dźwięków. Jego twórczość pisarska świadczy jednak o dużej wrażliwości na dźwięki, o zdolności dostrzegania ich kolorystyki w sensie skojarzeń międzysensorycznych oraz o umiejętności takiego posługiwania się słowem, by przekazać czytelnikowi różnorodność owych bodźców zmysłowych. Być może więc zdolność barwnej recepcji dźwięków jest w przypadku Nabokova naturalną konsekwencją odczuwanego od dzieciństwa niedosytu w sferze muzyki i dążenia do precyzyjnego opisu dźwięków.

Doświadczane przez pisarza barwy dźwięków dotyczą przede wszystkim dźwięków mowy i ludzkiego głosu oraz dźwięków muzyki. Epitet 'lovely dark' (voice) ${ }^{56}$ opisuje barwę głosu Ady Veen. Podobną, ciemną barwę Van usłyszał w głosie Corduli podczas rozmowy telefonicznej:

When she rang him up and pleaded for an interview (in a new, darker voice, agonizingly resembling Ada's), she intimated that she was bringing him an important message"s7.

Inaczej zaś głos Ady brzmiał dla Vana po latach rozłąki, gdy w słuchawce telefonu usłyszał 'jasną wibrację jej strun głosowych'. Wspomnienia nadały głosowi Ady nowych barw i rysów, dostarczając przy tym 'quasi-erotycznej przyjemności':

56 V. Nabokov, Ada or Ardor: A Family Chronicle..., s. 125.

57 Ibidem, s. 366. 
Now it so happened that she had never - never, at east, in adult life - spoken to him by phone; hence the phone had preserved the very essence, the bright vibration, of her vocal cords, the little "leap" in her larynx, the laugh clinging to the contour of the phrase, as if afraid in girlish glee to slip off the quick words it rode. It was the timbre of their past, as if the past had put through that call, a miraculous connection ("ardis, one eight eight six" - comment? Non, non, pas huitante-huit - huitante-six). Goldenly, youthfully, it bubbled with all the melodious characteristics he knew - or better say recollected, at once, in the sequence they came: that entrain, that whelming of quasi-erotic pleasure, that assurance and animation - and, what was especially delightful, the fact that she was utterly and innocently unaware of the modulations entrancing him ${ }^{58}$.

Doktor Azureus w Nieprawym godle ma zwyczaj witania swych gości w szczególny, sobie tylko właściwy sposób, składający się z kilku etapów, podczas jednego z których na jego twarzy pojawia się srebrzysty uśmiech:

Old Azureus's manner of welcoming people was a silent rhapsody. Ecstatically beaming, slowly, tenderly, he would take your hand between his soft palms, hold it thus as if it were along sought treasure or a sparrow all fluff and heart, in moist silence, peering at you the while with his beaming wrinkles rather than with his eyes, and then, very slowly, the silvery smile would start to dissolve, the tender old hands would gradually release their hold, a blank expression replace the fervent light of his pale fragile face, and he would leave you as if he had made a mistake, as if after all you were not the loved one B. B. the loved one whom, the next moment, he would espy in another corner, and again the smile would dawn, again the hands would enfold the sparrow, again it would all dissolve ${ }^{59}$.

Srebrną precyzję Humbert usłyszał w głosie przypadkowo poznanej Monique, świadczącej usługi seksualne: „I asked her price, and she promptly replied with melodious silvery precision (a Bird, a very bird!) Cent" ${ }^{\prime 60}$. W odniesieniu natomiast do dwóch

58 Ibidem, s. 555.

59 V. Nabokov, Bend Sinister, Henry Holt and Company, New York 1947, s. 31 .

60 V. Nabokov, Lolita..., s. 21. 
nimfetek używa określenia 'słoneczne głosy', przy czym nie bez znaczenia jest jego (seksualne) zainteresowanie dorastającymi dziewczynkami:

Two little girls, Marion and Mabel, whose comings and goings I had mechanically followed of late [...], one pushing a bicycle, the other feeding from a paper bag, both talking at the top of their sunny voices ${ }^{61}$.

Bliski barwie słonecznych głosów Marion i Mabel jest głos leśnego licha, które do narratora opowiadania Leśne licho przemawia głosem jego wspomnień i tęsknoty do przeszłości: „и голос его звенел, шелестел, золотой, сочно-зеленый, знакомый, - а слова были все такие простые, людские..."62 Soczystozielona barwa głosu odnosi tę baśniową postać do opuszczonej przez narratora ojczyzny, do bliskich jego sercu zielonych lasów.

Złocista barwa pobrzmiewa również w chichocie Lolity

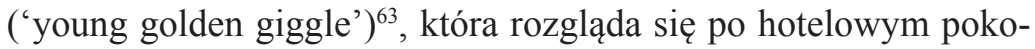
ju i domyślnie kończy zdanie Humberta o kazirodczych relacjach między osobami zamieszkującymi jeden pokój.

Gołębie samogłoski angielskie dały się słyszeć w głosie Izabel: „Изабель тихо заскользила по голубиным гласным английской речи..." ${ }_{64}$, a z portu dobiegał miedziany prowansalski głos: „Медный провансальский голос затараторил где-то в окне” 65 .

Nabokov kolorystycznie opisuje dźwięki głosów swych bohaterów nie tylko podczas wypowiadania przez nich słów czy podczas śmiechu, ale też w czasie wykonywania przez nich utworów wokalnych, jak w przypadku Freda Dobsona: „Так объехал карлик большую часть Европы и откладывал деньги, пел серебряным евнушьим дискантом..." ${ }^{66}$ Pieśń słyszana przez Erwina z kolei

61 Ibidem, s. 73.

62 В. В. Набоков, Нежить, [w:] В. В. Набоков, Полное собрание рассказов..., s. 48.

63 V. Nabokov, Lolita..., s. 119.

64 В. В. Набоков, Удар крыла.., s. 58.

65 В. В. Набоков, Порт..., s. 84.

66 В. В. Набоков, Картофельный Эльф..., s. 100. 
śpiewana była miodowym tenorem: „Свет на дворе был ровнее; невдалеке медовым тенором заливался соседский граммофон"67.

Pisarz nie pozostawał też obojętny wobec muzyki instrumentalnej, której dźwięki, a nawet pojedyncze nuty określał za pomocą barw. O kolorze dźwięku muzyki fortepianowej mówi bohater opowiadania Muzyka. Na zakończenie koncertu, który stanowi tło dla wspomnień i rozmyślań o przeżytej i utraconej miłości, pianista wydobywa $\mathrm{z}$ instrumentu jeden prosty złoty ton:

Последние звуки, многопалые, тяжкие, [...] и после этого, уже заключительного, уже как будто всю душу отдавшего аккорда, пианист нацелился и с кошачьей меткостью взял одну, совсем отдельную, маленькую, золотую ноту 68 .

Złote drżenie towarzyszy też dźwiękom muzyki podczas wykonań pianisty i kompozytora Bachmanna:

В те дни золотой, глубокий, сумасшедший трепет его игры запечатлевался уже на воске, а заживо звучал в знаменитейших концертных залах ${ }^{69}$.

Wśród innych rodzajów dźwięków nazwanych w omawianych tekstach Nabokova jest szum w głowie Martina, który przybrał przezroczystą barwę:

Вдруг, с непривычным еще чувством, Мартын вспомнил густую еловую опушку русского парка сквозь синее ромбовидное стекло на веранде, - a когда, разминая слегка звенящие ноги, с прозрачным гулом в голове, он вышел из автомобиля... ${ }^{70}$

${ }^{67}$ В. В. Набоков, Сказка, [w:] В. В. Набоков, Полное собрание расска3ов..., s. 221.

68 В. В. Набоков, Музыка, [w:] В. В. Набоков, Полное собрание рассказов..., s. 343 .

69 В. В. Набоков, Бахман, [w:] В. В. Набоков, Полное собрание расска$308 \ldots$, s. 171.

70 В. В. Набоков, Подвиг, [w:] В. В. Ерофеев (ред.), Владимир Набоков. Собрание сочинений в четырех томах, т. 2, Издательство «Правда», Москва 1990, s. 183. 
Tęsknota za Rosją we wczesnych opowiadaniach uwidacznia się $\mathrm{w}$ opisach przyrody obfitujących $\mathrm{w}$ doznania zmysłowe, w tym również wrażenia synestezyjne. Przykładem może być Słowo, w którym narrator doświadcza wizji kroczących obok niego jaśniejących i promieniujących aniołów. Jeden z nich wypowiada cudowne słowo, a jego promienny dźwięk dociera do wszystkich zakamarków świadomości bohatera:

И, на мгновенье обняв плечи мои голубиными своими крылами, ангел молвил единственное слово, - и в голосе его я узнал все любимые, все смолкнувшие голоса. Слово, сказанное им, было так прекрасно, что я со вздохом закрыл глаза и еще ниже опустил голову. Пролилось оно благовоньем и звоном по всем жилам моим, солнцем встало в мозгу - и бессчетные ущелья моего сознанья подхватили, повторили райский сияющий звук. Я наполнился им; тонким узлом билось оно в виску, влагой дрожало на ресницах, сладким холодом веяло сквозь волосы, божественным жаром обдавало сердце ${ }^{71}$.

\section{dźwięk - synestezyjny dotyk}

Wrażenia typowe dla doznań dotykowych w tekstach Nabokova często przenoszone są na dźwięki. Dotyczy to zarówno przypadków metafory literackiej z włączeniem celowego działania autora, jak i przypadków synestezji, choć przykładów należących do tej drugiej grupy jest zdecydowanie mniej.

Określeniem, które pojawia się w kilku przykładach tego rodzaju synestezji jest przymiotnik 'aksamitny' ('бархатный', 'velvety'), oznaczający to, co zrobione z aksamitu lub co ma cechy aksamitu, to znaczy jest miękkie i gładkie ${ }^{72}$. Choć cechy te przeważnie odnoszone są do właściwości sprawdzanych w sposób dotykowy, to 'aksamitny głos' należy do konstrukcji powszechnie używanych i chyba już nawet nie odczuwanych jako metafora, a tym bardziej

${ }_{71}$ В. В. Набоков, Слово, [w:] В. В. Набоков, Полное собрание рассказов..., s. 53.

72 Por. np. hasło бархат / бархатистый w słowniku: С. И. Ожегов, Словарь русского языка, под ред. Н. Ю. Шведовой, «Русский язык», Москва 1987. 
synestezja. Nabokov określił w ten sposób głos służącej, który oderwał Humberta od podniecającej Lolity:

A poignant chaos was welling within me - but I had to drop those things and hurriedly regain my composure, as I became aware of the maid's velvety voice calling me softly from the stairs ${ }^{73}$.

Przeważnie jednak pisarz wykracza poza konwencjonalne, niezaskakujące użycie przymiotnika i łączy je z określonym rodzajem głosu męskiego, ciszy, a nawet grzmotu - 'aksamitny baryton':

Он [Аркадий Петрович Зарянский] был лысоват, с прекрасным, напористым профилем, но [...] человек же он был мягкий, добродушный, чувствительный и, когда по ночам все выходили гулять, пел бархатным баритоном... ${ }^{74}$

\section{'aksamitna cisza':}

Сначала на черном бархате, каким по ночам обложены с исподу веки, появилось, как медальон, лицо Марфиньки. [...] Она заморгала, поворачивая голову, и на мягкой, сливочной белизны, шее, была черная бархатка, а бархатная тишина платья, расширяясь книзу, сливалась с темнотой ${ }^{75}$.

'aksamitny grzmot':

В глубине черными складками нарастает бархатный гром7.

'aksamitne stukanie':

Раздался легкий стук в стену из комнаты танцоров. [...] Стук повторился опять, по-женски бархатный: это, верно, стучал Колин ${ }^{77}$.
73 V. Nabokov, Lolita..., s. 67.
74 В. В. Набоков, Подвиг..., s. 167.
75 В. В. Набоков, Приглашение на казнь.., s. 11.
76 В. В. Набоков, Боги ..., s. 40.
77 В. В. Набоков, Машенька..., s. 61. 
Co ciekawe, skojarzenia „бархатный баритон” і „бархатная тишина" pojawiają się w otoczeniu określeń miękkości i wrażliwości, potęgujących doznanie aksamitnego dotyku. W pierwszym przypadku opis dotyczy 'miękkiego, dobrodusznego i wrażliwego' Arkadiego Zarianskiego, w drugim zaś 'aksamitna cisza', poprzez powtórzenie бархатка - бархатная, nawiązuje do czarnej aksamitki na miękkiej szyi Marfinki.

Miękkość dźwięku, podobnie jak 'aksamitny głos', nie jest odczuwana jako metaforyczna czy synestezyjna, choć łączy pojęcia nieprzystające do siebie: dźwięk odbierany organem słuchu i miękkość - dotykiem. O miękkości dźwięku mówi się w muzyce w odniesieniu do dźwięku wydobywanego z instrumentu muzycznego lub wytwarzanego przez struny głosowe. W językoznawstwie miękkość i twardość stanowią jedną z dystynktywnych cech spółgłosek. Sama miękkość dźwięku ma zatem w języku pozycję na tyle utartą i rozpowszechnioną, że jej obecność w tekście literackim nie budzi zaskoczenia. Uwagę zwraca natomiast doprecyzowanie owej miękkości poprzez dodatkowe określenie, na przykład 'futrzana miękkość głosu'. W Adzie Lucette podczas rozmowy zadaje pytania głosem o niskich tonach, nadających mu futrzaną miękkość (dosłownie: ,pokrywających go futrem”):

She asked questions with pretty co-ed looks of doelike devotion, but it did not require much scientific training on a professor's part to perceive that her charming embarrassment and the low notes furring her voice were as much contrived as her afternoon effervescence had been ${ }^{78}$.

Bliski w swoim charakterze futrzanej miękkości dźwięku puszysty szelest pojawia się w wizji aniołów w Stowie:

Я видел огненные паутины, брызги, узоры на гигантских, рдяных, рыжих, фиолетовых крыльях, - надо мной проходили волны пушистого шелеста, шныряли бирюзовые птицы в радужных венцах, плыли цветы, срываясь с блестящих ветвей... ${ }^{79}$

78 V. Nabokov, Ada or Ardor: A Family Chronicle..., s. 484.

79 В. В. Набоков, Слово..., s. 51. 
Przeciwną miękkości twardość przywodzi z kolei na myśl ‘drewniany głos’ Lidii Nikołajewny w Maszeńce:

Сегодня - барашек, - провозгласила вдруг Лидия Николаевна деревянным голоском, исподлобья глядя, как жильцы ее невнимательно едят жаркое 80.

Uczucie lepkości słyszanych odgłosów dotyczy człapania pantoflami w pierwszym z poniższych przykładów i szmeru wydobywania daktyla z pudełka - w drugim.

Родион собрался свирепо захлопнуть уже визжавшую дверь, но, как и вчера, - липко шлепая сафьяновыми туфлями, дрыгая полосатыми телесами, держа в руках шахматы, карты, бильбоке... ${ }^{81}$

Инженер Керн, близко знавший покойного Александра Блока, извлекал из продолговатой коробки, с клейким шорохом, финик ${ }^{82}$.

Inny rodzaj przeniesienia wrażeń dotykowych na słuchowe dotyczy swoistej materializacji dźwięku i nasączenia go cieczą. Stopień wilgotności można stwierdzić palpacyjnie lub wzrokowo, jeśli jest on na tyle duży, by wywołać nabłyszczenie powierzchni. W przypadku dźwięku o żadnej powierzchni nie może być mowy, podobnie jak w ogóle o napełnieniu dźwięku wodą, Tymczasem synestezyjne wrażenie wilgotnego dźwięku napotkamy w Zaproszeniu na egzekucję w sposobie, w jaki sędzia wypowiadał słowa: „судья [...] произнес сырым шепотом: «с любезного разрешения публики, вам наденут красный цилиндр»" "83.

W opowiadaniu Muzyka 'wilgotny dźwięk' skojarzony został ze słowem «счастье», które oprócz wyobrażeń typowych dla doznań związanych z kontaktem z wodą wywołuje też skojarzenia o charakterze personifikacyjnym:

80 В. В. Набоков, Машенька, [w:] В. В. Ерофеев (ред.), Владимир Набоков. Собрание сочинений в четырех томах, т. 1, Издательство «Правда», Москва 1990, s. 46.

81 В. В. Набоков, Пригламение на казнь.., s. 82.

82 В. В. Набоков, Дар..., s. 31.

83 В. В. Набоков, Приглашение на казнь..., s. 11. 
Он влюбился в нее без памяти в душный обморочный вечер на веранде теннисного клуба, - а через месяц, в ночь после свадьбы, шел сильный дождь, заглушавший шум моря. «Как мы счастливы». Шелестящее, влажное слово «счастье», плещущее слово, такое живое, ручное, само улыбается, само плачет, - и утром листья в саду блистали, и моря почти не было слышно, - томного, серебристо-молочного моря ${ }^{84}$.

Brzmieniowe doznania związane $\mathrm{z}$ artykulacją spółgłosek w słowie 'счастье', odbieranych jako 'szeleszczące', zostały wzmocnione przez zestawienie w tekście uczucia szczęścia z deszczową aurą i zagłuszającym szumem morza. Nieco dalej znajdziemy inną, choć nadal związaną z wodą, cechę doświadczanego wrażenia 'płynności' szczęścia: «Мы будем счастливы всегда», - как это звучало, как переливалось... ${ }^{85}$

Po raz kolejny na doznanie wilgotnego dźwięku, doświadczanego przez Martina pod wpływem dzwonków stada owiec podążającego drogą, natkniemy się w Splendorze:

[...] и вот, в облаке пыли, серой, курчавой густыней лились, мягко толкаясь, овечьи спины в переменчивой и подвижной тесноте, и влажный, полый, услаждающий все чувства звон колокольцев все рос, наливался, так таинственно, словно звучала самая пыль, клубящаяся над овцами... ${ }^{86}$

Wspomniany już wcześniej dr Azureus w specyficzny sposób wita się z gośćmi w 'wilgotnej ciszy', co warto przywołać, cytując jeszcze raz ów fragment powieści:

Old Azureus's manner of welcoming people was a silent rhapsody. Ecstatically beaming, slowly, tenderly, he would take your hand between his soft palms, hold it thus as if it were along sought treasure or a sparrow all fluff and heart, in moist silence, peering at you the while with his beaming wrinkles rather than with his eyes... ${ }^{87}$

${ }^{84}$ В. В. Набоков, Музыка, [w:] В. В. Набоков, Полное собрание рассказов..., s. 341.

85 Ibidem.

86 В. В. Набоков, Подвиг..., s. 184.

87 V. Nabokov, Bend Sinister, Henry Holt and Company, New York 1947, s. 31. 
Nasączenie dźwięku cieczą nie zawsze jednak jest całościowe i równomierne. Przykład z Daru pokazuje, że wilgoć może się zgromadzić na brzegach głosu, najwyraźniej środek pozostawiając suchym: „Первый матрос, второй матрос, третий матрос», - нервным, с мокрыми краями баском пересчитывал Буш беседующих лиц"88. 1

Inny rodzaj połączonych doznań dźwiękowych $\mathrm{z}$ dotykowymi dotyczy sposobu przemieszczania się po ogrodzie srebrzystych widm: „По саду, по зелени, по оранжевому песку, свежо и скользко шумя, неслись громадные серебряные призраки" ${ }^{89}$.

dźwięk - synestezyjna temperatura

Podczas pieszej wędrówki do Molignac, miejscowości oddalonej o piętnaście kilometrów, Martin, bohater Splendoru, usłyszał „прохладный звук воды и подумал, что в мире нет лучше музыки" ". W skwarny dzień szum płynącej wody (dźwięk) wywołał wyobrażenie chłodnej, przynoszącej ulgę wody strumienia. W innym znów miejscu Martin doświadczył uczucia chłodnej ciszy świerkowego boru:

$[\ldots]$ в глубине, в еловом бору, сразу за садом, и на мягкой дороге, ведущей в деревню, была прохладная, веселая, что-то знающая тишина ${ }^{91}$.

Skojarzenie odczucia niskiej temperatury towarzyszyło też Ganinowi w Maszeńce, gdy opisywał wyimaginowany obraz przejeżdżającego przez pokój pociągu z wydawanymi przez niego dźwiękami:

[...] Ганин никогда не мог отделаться от чувства, что каждый поезд проходил незримо сквозь толщу самого дома; вот он вышел с той стороны, призрачный гул его расшатывает стену, толчками пробирается он по

88 В. В. Набоков, Дар ..., s. 62.

89 В. В. Набоков, Збуки ..., s. 25.

90 В. В. Набоков, Подвиг..., s. 265.

${ }_{91}$ Ibidem, s. 184. 
старому ковру, задевает стакан на рукомойнике, уходит, наконец, с холодным звоном в окно, - и сразу за стеклом вырастает туча дыма...92

Uciążliwe brzęczenie much w skwarny dzień w porcie opisane zostało za pomocą wrażenia synestezyjnego, przy czym zabieg wykorzystania instrumentacji dźwiękowej powielającej onomatopeiczne w tym przypadku ,ж” wzmocnił doznania słuchowe: Жарко и тяжело жужжали мухи ${ }^{93}$.

dźwięk - synestezyjny ból

Projekcja doznań bólowych na dźwiękowe spotykana jest u Nabokova niezmiernie rzadko. Przykład ilustrujący tę odmianę synestezji pochodzi z opowiadania La Veneziana:

[...] неуклюжее сухое полено, от которого мяч отмигивает с болезненным треском, попадая то в сетку, то в кусты и норовя даже сшибить соломенную шляпу с круглой плечи господина Магора...94

\section{Doznania związane ze smakiem}

\section{kolor smaku}

Doznania związane ze smakiem należą do bardzo rzadkich synestezyjnych wrażeń u Nabokova. Jedyny zaobserwowany w zebranym materiale przykład przenosi doznania kolorystyczne na smak:

Помню, что мелкие признаки бытия, - щекотка в носу, голод, и потом рыжий вкус шницеля в ресторане, - странно меня занимали, точно я искал и находил (и все-таки слегка сомневался) доказательства тому, что я - я, что я (средней руки коммерсант с замашками) действительно нахожусь в гостинице, обедаю, думаю о делах и ничего не имею общего с бродягой, валяющимся сейчас где-то за городом, под кустом ${ }^{95}$.

92 В. В. Набоков, Машенька..., s. 41.

93 В. В. Набоков, Порт..., s. 84.

94 В. В. Набоков, Венецианка, [w:] В. В. Набоков, Полное собрание рассказов..., s. 145.

95 В. В. Набоков, Отчаяние, [w:] В. В. Ерофеев (ред.), Владимир Набоков. Собрание сочинений в четырех томах, т. 3, Издательство «Правда», Москва 1990, s. 341. 
Jürgen Bodenstein zauważa, że w większości percepcji synestezyjnych na wyrażenie jednego doznania w kategoriach innego mają wpływ pewnego rodzaju asocjacje drugoplanowe. Jako przykład podaje powyższe skojarzenie smaku i koloru w jego angielskim wariancie: „the rough brown taste of a cutlet”, wyjaśniając barwę smaku sznycla kolorem mięsa ${ }^{96}$. Trudno temu zaprzeczyć: usmażony sznycel może mieć barwę brązową lub jej złotawy odcień (por. brązowy smak w wersji angielskiej i rudy - w rosyjskiej). Jeśli jednak tak jest, to w przypadku tej konstrukcji mówić należy o udziale czynnika konceptualnego.

\section{Doznania związane z dotykiem}

dotyk - synestezyjny kolor

Wasilij Iwanowicz, bohater opowiadania Obłok, jezioro, zamek, przez okna jadącego pociągu dostrzega granatową wilgoć jaru:

Деревья появлялись партиями и отдельно, поворачивались равнодушно и плавно, показывая новые моды. Синяя сырость оврага ${ }^{97}$.

\section{Doznania związane z zapachem}

zapach - synestezyjny kolor

Dwa przykłady, tworzące grupę doznań barwnego zapachu, pochodzą z powieści Lolita i opowieści Czarodziej. W pierwszym z wymienionych tekstów Humbert określa zapach brudnych włosów Lolity jako brązowy: ,Although I do love that intoxicating brown fragrance of hers, I really think she should wash her hair once in a while" $"$. W drugim natomiast główna bohaterka owiewa swego 'opiekuna' - pedofila - kasztanowym zapachem miękkich włosów:

96 J. Bodenstein, ,, The Excitement of Verbal Adventure”: A Study of Vladimir Nabokov's English Prose, t. I, Heidelberg 1977, s. 228.

97 В. В. Набоков, Облако, озеро, башня, [w:] В. В. Набоков, Полное собрание рассказов..., s. 440.

98 V. Nabokov, Lolita..., s. 43. 
„Моя душенька, моя бедная девочка”, - проговорил он в каком-то общем тумане жалости, нежности, желания, глядя на её сонность, дымчатость, заходящую улыбку, ощупывая её сквозь темное платье, чувствуя на голом, сквозь тонко-шерстяное, полоску сиротской подвязки, думая о её беззащитности, заброшенности, теплоте, наслаждаясь живой тяжестью её расползавшихся и опять, с легчайшим телесным шорохом, повыше скрещивающихся ног, - и она медленно обвила вокруг его затылка сонную руку в тесном рукавчике, обдавая его каштановым запахом мягких волос, но рука сползла, подошвой сандалии она дремотно отталкивала несессер, стоявший рядом с креслом...99

Zbieżność doznań wydaje się nieprzypadkowa. Czarodziej traktowany jest przez niektórych badaczy jako szkic Lolity. Argumentem, który za tym przemawia, jest - zdaniem Aleksandra Dolinina - podobieństwo dotyczące ,fabuły z jej motywacją opartą na patologii seksualnej i z naznaczonymi erotyzmem opisami dziecięcego ciała"100. Z takim stanowiskiem polemizuje Leszek Engelking, który uważa, że obydwa teksty są odrębnymi utworami i w ten sposób powinny być rozpatrywane ${ }^{101}$. Nie zmienia to jednak faktu, że Czarodziej przeważnie nie jest rozważany w oderwaniu od Lolity.

zapach - synestezyjny dotyk

We wszystkich zacytowanych niżej fragmentach wrażenia charakterystyczne dla dotyku wywołane zostały przez zapach pochodzący od roślin: świerkowego drzewa, z którego zbudowano dom, pączków topoli, kwiatów. Za każdym razem jednak transfer doznań zmysłowych wiąże się z innym odczuciem dotykowym.

'szorstki zapach'

Вдруг, с непривычным еще чувством, Мартын вспомнил густую еловую опушку русского парка сквозь синее ромбовидное стекло на веранде,

99 В. В. Набоков, Волшебник, Изд. Сипмозиум, 2000, wersja on-line: http:// royallib.com/book/nabokov_vladimir/volshebnik.html [dostęp: 10.12.2014], s. 20.

100 Podaję za: L. Engelking, Chwyt metafizyczny. Vladimir Nabokov - estetyka z sankcją wyższej rzeczywistości, Wydawnictwo UŁ, Łódź 2011, s. 304.

101 Ibidem, s. 301-308. 
- а когда, [...] он вышел из автомобиля, его поразил запах земли и тающего снега, шероховатый свежий запах и еловая красота дядиного дома $^{102}$.

'lepko pachnieć'

[...] липко пахло тополевыми почками, а далеко за площадью круглый крематорий имел теперь сытый, облизанный вид ${ }^{103}$.

'wilgotny zapach'

[...] и ветер, как предчувствие чуда, играл в моих волосах, хрустальным гулом наполнял ущелья, волновал сказочные шелка деревьев, цветущих между скал, вдоль дороги; вверх по стволам взлизывали длинные травы, словно языки огня; крупные цветы плавно срывались с блестящих ветвей и, как летучие чащи, до краев налитые солнцем, скользили по воздуху, раздувая прозрачные, выпуклые лепестки; запах их, сырой и сладкий, напоминал мне все лучшее, что изведал я в жизни ${ }^{104}$.

Podobne określenie zapachu napotkamy w Maszeńce w opisie pielęgniarki, od której Ganin poczuł „сыроватый запах, стародевичью прохладу"105.

zapach - synestezyjny smak

Przedstawiony wyżej fragment opowiadania Słowo oprócz przykładu synestezyjnego dotyku wywołanego zapachem zawiera też konstrukcję odpowiadającą synestezyjnemu smakowi pod wpływem tego samego bodźca: „сладкий запах”. Podobnie też odczucie słodkiego zapachu pojawia się w Splendorze: „Стрекотали кузнечики, по временам несло сладкой хвойной гарью..."106

102 В. В. Набоков, Подвиг..., s. 183.

103 В. В. Набоков, Дар..., s. 281.

104 В. В. Набоков, Слово..., s. 50.

105 В. В. Набоков, Машенька..., s. 56.

106 В. В. Набоков, Подвиг..., s. 168. 
zapach - synestezyjna temperatura

Wśród przykładów pojawiają się zaledwie dwa przeciwstawne sobie określenia zapachu związane z temperaturą. Pierwsze z nich, 'теплый', wykorzystane zostało w kilku różnych utworach. W Kartoflanym Elfie ciepły zapach odnosi się do benzyny: „Карлик шел, вдыхая теплый запах бензина, запах листвы, как бы уже гниющей от избытка зеленого сока..." 107 W opowieści Czarodziej jej bohaterka opisana jest w nocy, na ulicy, pośród ciepłego zapachu spalenizny:

Она почти дремала, выползая на панель, застывая в сиреневатой, щербатой тьме, в теплом запахе гари, в шуме и дрожи двух, трех, четырех грузовиков, пользовавшихся ночным безлюдием, чтобы чудовищно быстро съезжать под гору из-за угла улицы, где ныл, и тужился, и скрежетал скрытый подъём108.

Natomiast w powieści Maszeńka główny bohater, Ganin, poczuł ciepły zapach rozmawiającego z nim Aleksieja Alfierowa:

Альферов шумно вздохнул; хлынул теплый, вялый запашок не совсем здорового, пожилого мужчины. Есть что-то грустное в таком запашке109.

Drugie określenie temperatury zapachu, 'холодный', dotyczy doznań, które w czasie seansu w kinie przywołują u Ganina nieprzyjemne wspomnienia z przeszłości:

Ганин, сидевший между ними, был раздражен тем, что Людмила, как большинство женщин ее типа, все время, пока шла картина, говорила о посторонних вещах, перегибалась через колени Ганина к подруге, обдавая его каждый раз холодным, неприятно-знакомым запахом духов ${ }^{110}$.

Połączenie w tym fragmencie wrażenia chłodu z bodźcem nieprzyjemnie znanego zapachu jest tutaj nieprzypadkowe. Przymiotniki „ciepły” i ,zimny” często pełnią w języku funkcje dodatniego

107 В. В. Набоков, Картофельный Эльф..., s. 106.

108 В. В. Набоков, Волшебник..., s. 19.

109 В. В. Набоков, Маменька..., s. 36.

110 Ibidem, s. 49. 
i ujemnego (odpowiednio) wartościowania. Wystarczy porównać frazeologizmy typu „ciepłe słowa”, „ciepły uśmiech”, „lodowate spojrzenie" "111. Podobnie ,zimny zapach perfum” w Nabokovowskiej Maszeńce ma wydźwięk negatywny.

\section{Doznania związane z temperaturą}

Temperatura otoczenia przekazywana jest niekiedy w synestezyjnych asocjacjach z doznaniami dotykowymi i smakowymi. Trzeba zaznaczyć, że nie oznacza ona tylko temperatury powietrza, ale też temperaturę uczuć i stan emocjonalny bohatera, jak w przykładzie pochodzącym z Lolity.

temperatura - synestezyjny dotyk

[...] surely, you all know those redolent remnants of day suspended, with the midges, about some hedge in bloom or suddenly entered and traversed by the rambler, at the bottom of a hill, in the summer dusk; a furry warmth, golden midges ${ }^{112}$.

temperatura - synestezyjny smak

Вкусный холодок прошел по макушке, пальцы крепко втирали густую пену... ${ }^{113}$

\section{Doznania związane z bólem}

ból - synestezyjny kolor

Цинциннат лежал на плитах крестом [...] и, потворствуя ряжению чувств, ясно, через слух видел потайной ход, удлиняющийся с каждым скребом, и ощущал, словно ему облегчали темную, тесную боль в гру-

111 Por.: B. Kuryłowicz, , Jak purpurowy zapach róży...” Metafory synestezyjne w młodopolskich tekstach poetyckich, „Białostockie Archiwum Językowe” 2011, nr 11, s. 105-106.

112 V. Nabokov, Lolita..., s. 10.

113 В. В. Набоков, Порт..., s. 84. 
ди, как расшатываются камни, и уже гадал, глядя на стену, где-то она даст трещину и с грохотом разверзнется ${ }^{114}$.

Ciemny ból w piersiach Cyncynata zdawał się ustępować pod wpływem nadziei na ucieczkę z więzienia. Ostatniego dnia natomiast, dwie godziny przed zaplanowaną i spodziewaną egzekucją, Cyncynat spisuje swoje myśli i z lękiem wyobraża sobie moment ścinania głowy oraz towarzyszący mu czerwony, głośny ból: „Я полагаю, что боль расставания будет красная, громкая" 115 .

Czarny lity ból głowy, znacznie silniejszy niż szara jego zapowiedź - ból przedramienia, był doznawany przez głównego bohatera powieści Patrz na te arlekiny: „The neuralgia in my right forearm was a gray adumbration compared to the solid black headache that no pill could pierce"116. Dalej w powieści jeszcze raz pojawia się wzmianka o czerni bólu Wadima Wadimowicza: „As I stood there, my head brimming with a blackness of pain seldom known before, I became aware of a flurry of motion beyond the court" 117 .

\section{Doznania polisensoryczne}

Oprócz szeregu różnorodnych doznań łączących dwie modalności, w tekstach Nabokova napotkać można przykłady, w których wrażenia powstają w kilku modalnościach zmysłowych.

słyszenie dotykowo-barwnego zapachu

Dla narratora opowiadania Wiosna $w$ Fialcie nazwa 'Fialta' oznacza coś więcej niż tylko miejsce geograficzne, wywołując osobiste wspomnienia i skojarzenia:

Я этот городок люблю; потому ли, что во впадине его названия мне слышится сахаристо-сырой запах мелкого, темного, самого мятого из

114 В. В. Набоков, Приглашение на казнь.., s. 84.

115 Ibidem, s. 112.

116 V. Nabokov, Look at the Harlequins!, McGraw-Hill Book Company, New York 1974, s. 125.

117 Ibidem, s. 146. 
цветов,и не в тон, хотя внятное, звучание Ялты; потому ли, что его сонная весна особенно умащивает душу, не знаю...118

Nazwa miasteczka wywołuje jednocześnie doznania słuchowe, zapachowe z domieszką odczuć, które można uznać za dotykowe (сырой). Wrażenia kolorystyczne są natomiast wywoływane przez nazwę, która brzmieniowo kojarzy się z barwą fioletową i kwiatem bzu. Mamy tu zatem do czynienia z synestezyjnym dźwiękiem, zapachem, dotykiem i kolorem wywoływanymi przez brzmienie nazwy.

zapach smakowo-kolorystyczny

[...] однако, тут же его невольно отрезвляла какая-нибудь ее интонация, смешок, веяние тех определенных духов, которыми почему-то душились как раз те женщины, которым он нравился, хотя ему был как раз невыносим этот мутный, сладковато-бурый запах ${ }^{119}$.

zapach kolorystyczno-dotykowy

Они долго шли берегом, взбегали на скользкие скаты, отыскали тропинку, где черной сыростью пахнуло от кустов орешника ${ }^{120}$.

zapach temperatury dźwięku (zapach + temperatura + dźwięk)

Martin, urażony faktem, że Sonia i Darwin wybrali się na tańce bez niego, w wyobraźni widział i odczuwał atmosferę balu, jego dźwięki i zapachy:

Он видел себя взлетающим по мягким ступеням, в смокинге, в шелковой рубашке с набористой грудью, как носили франты в тот год, в лег-

118 В. В. Набоков, Весна в Фиальте, [w:] В. В. Набоков, Полное собрание рассказов..., s. 421.

119 В. В. Набоков, Дар..., s. 148.

120 В. В. Набоков, Натама, [w:] В. В. Набоков, Полное собрание рассказов..., s. 141. 
ких лаковых туфлях с плоскими бантами; вот - из раскрывшихся дверей пахнуло огнем музыки ${ }^{121}$.

Niektóre z podanych wyżej przykładów budzić mogą wątpliwości związane z zakwalifikowaniem ich do kategorii skojarzeń synestezyjnych, a nie do metafor o charakterze synestezyjnym. Należy do nich na przykład 'chłodny dźwięk płynącej wody' (прохладный звук воды). Duże znaczenie w nterpretacji odgrywa czynnik związany z zapamiętywaniem i gromadzeniem wspomnień. Pamiętamy, że woda w strumieniu jest zimna, dlatego szum strumienia przywoła informację o niskiej temperaturze jego wody. Wiele przemawia za tym, że ten sam czynnik bierze udział w powstawaniu i utrwalaniu skojarzeń synestezyjnych o podłożu neuronalnym. Dlatego właśnie przypadki te znalazły swe miejsce w części poświęconej doznaniom międzysensorycznym.

\section{Podsumowanie}

Podane wyżej liczne przykłady konstrukcji synestezyjnych odkrywają przed czytelnikiem świat osobistych sensorycznych doświadczeń Nabokova. Zestawienie ich odmian w tabeli pozwoli dojrzeć w ich wielości i różnorodności pewne tendencje, które wynikają z naturalnych, wrodzonych predyspozycji pisarza oraz w pewnym, niewielkim stopniu również z upodobań do łączenia określonych wrażeń.

121 В. В. Набоков, Подвиг..,, s. 210. 
Tabela 2

Rodzaje międzysensorycznych doznań Vladimira Nabokova

\begin{tabular}{|c|c|c|}
\hline $\begin{array}{c}\text { Rodzaj } \\
\text { doznania }\end{array}$ & Odmiana synestezji & Konstrukcja synestezyjna \\
\hline 1 & 2 & 3 \\
\hline \multirow{4}{*}{$\begin{array}{l}\text { Doznania } \\
\text { związane } \\
\text { z widzeniem }\end{array}$} & barwa - synestezyjny smak & $\begin{array}{l}\text { kolor domu - synestezyjny smak } \\
\text { chałwy i owsa; } \\
\text { gorzkie światło; } \\
\text { nieapetyczne barwy poduszek }\end{array}$ \\
\hline & $\begin{array}{l}\text { barwa - synestezyjny } \\
\text { dźwięk }\end{array}$ & huczący blask ośnieżonego stoku \\
\hline & barwa - synestezyjny dotyk & $\begin{array}{l}\text { lepkie światło księżyca } \\
\text { lepko błyszczące usta } \\
\text { kleisty półmrok } \\
\text { kłujący granat }\end{array}$ \\
\hline & $\begin{array}{l}\text { barwa - synestezyjna tem- } \\
\text { peratura }\end{array}$ & ciepła ciemność \\
\hline $\begin{array}{l}\text { Doznania } \\
\text { związane } \\
\text { ze słyszeniem }\end{array}$ & $\begin{array}{l}\text { dźwięk } \\
\text { - synestezyjna barwa }\end{array}$ & $\begin{array}{l}\text { ciemny (ciemniejszy) głos } \\
\text { jasne wibracje strun głosowych } \\
\text { srebrna precyzja (słyszana w głosie) } \\
\text { srebrzysty śmiech } \\
\text { słoneczne głosy } \\
\text { złoty chichot } \\
\text { złoty, soczysto zielony głos } \\
\text { gołębie samogłoski } \\
\text { miedziany głos } \\
\text { srebrzysty tenor } \\
\text { miodowy tenor } \\
\text { złota nuta } \\
\text { blask dźwięku } \\
\text { przezroczysty szum w głowie } \\
\text { ksamitny głos } \\
\text { aksamitny baryton } \\
\text { aksamitna cisza } \\
\text { aksamitny grzmot } \\
\text { aksamitne stukanie } \\
\text { głos pokryty futrem } \\
\text { puszysty szelest }\end{array}$ \\
\hline
\end{tabular}




\begin{tabular}{|c|c|c|}
\hline 1 & 2 & 3 \\
\hline \multirow[t]{3}{*}{$\begin{array}{l}\text { Doznania } \\
\text { związane } \\
\text { ze słyszeniem }\end{array}$} & $\begin{array}{l}\text { dźwięk } \\
\text { - synestezyjny dotyk }\end{array}$ & $\begin{array}{l}\text { drewniany głos } \\
\text { lepkie człapanie pantoflami } \\
\text { lepki szmer } \\
\text { wilgotny szept } \\
\text { wilgotne słowo } \\
\text { wilgotny dźwięk dzwonków } \\
\text { wilgotna cisza } \\
\text { mokre brzegi basu } \\
\text { ślisko szumieć }\end{array}$ \\
\hline & $\begin{array}{l}\text { dźwięk - synestezyjna } \\
\text { temperatura }\end{array}$ & \begin{tabular}{|l|} 
chłodna cisza \\
chłodny dźwięk \\
zimne dzwonienie \\
upalne brzęczenie
\end{tabular} \\
\hline & dźwięk - synestezyjny ból & bolesny trzask \\
\hline $\begin{array}{l}\text { Doznania } \\
\text { związane } \\
\text { ze smakiem }\end{array}$ & kolor smaku & rudy smak sznycla \\
\hline $\begin{array}{l}\text { Doznania } \\
\text { związane } \\
\text { z dotykiem }\end{array}$ & kolor dotyku & granatowa wilgoć \\
\hline \multirow{3}{*}{$\begin{array}{l}\text { Doznania } \\
\text { związane } \\
\text { z zapachem }\end{array}$} & zapach - synestezyjny kolor & $\begin{array}{l}\text { brązowy zapach włosów } \\
\text { kasztanowy zapach włosów }\end{array}$ \\
\hline & zapach - synestezyjny dotyk & $\begin{array}{l}\text { szorstki zapach drewna } \\
\text { lepko pachnieć } \\
\text { wilgotny zapach kwiatów } \\
\text { wilgotnawy zapach (kobiety) }\end{array}$ \\
\hline & zapach - synestezyjny smak & $\begin{array}{l}\text { słodki zapach kwiatów } \\
\text { słodki zapach iglastej spalenizny }\end{array}$ \\
\hline
\end{tabular}


Tab. 2 (cd.)

\begin{tabular}{|l|l|l|}
\hline \multicolumn{1}{|c|}{1} & \multicolumn{1}{|c|}{2} & \multicolumn{1}{|c|}{3} \\
\hline $\begin{array}{l}\text { Doznania } \\
\text { związane } \\
\text { z zapachem }\end{array}$ & $\begin{array}{l}\text { zapach - synestezyjna tem- } \\
\text { peratura }\end{array}$ & $\begin{array}{l}\text { ciepły zapach benzyny } \\
\text { ciepły zapach spalenizny } \\
\text { ciepły zapach (człowieka) } \\
\text { zimny zapach perfum }\end{array}$ \\
\hline \multirow{2}{*}{$\begin{array}{l}\text { Doznania } \\
\text { związane } \\
\text { z temperaturą }\end{array}$} & $\begin{array}{l}\text { temperatura - synestezyjny } \\
\text { smak }\end{array}$ & smaczny chłodek \\
\cline { 2 - 3 } & $\begin{array}{l}\text { temperatura - synestezyjny } \\
\text { dotyk }\end{array}$ & puszyste ciepło \\
\hline \multirow{2}{*}{$\begin{array}{l}\text { Doznania } \\
\text { związane } \\
\text { z bólem }\end{array}$} & ból - synestezyjny kolor & $\begin{array}{l}\text { ciemny ból } \\
\text { czerwony ból } \\
\text { czarny ból głowy } \\
\text { czerń bólu głowy }\end{array}$ \\
\hline \multirow{3}{*}{$\begin{array}{l}\text { Doznania } \\
\text { polisenso- } \\
\text { ryczne }\end{array}$} & $\begin{array}{l}\text { słyszenie dotykowo-barwne- } \\
\text { go zapachu }\end{array}$ & \\
\cline { 2 - 3 } & $\begin{array}{l}\text { zapach smakowo-kolory- } \\
\text { styczny }\end{array}$ & \\
\cline { 2 - 3 } & zapach temperatury dźwięku & \\
\cline { 2 - 3 } & $\begin{array}{l}\text { zapach kolorystyczno-do- } \\
\text { tykowy }\end{array}$ & \\
\hline
\end{tabular}

Źródło: opracowanie własne.

Doznania, które pojawiają się u Nabokova najczęściej, dotyczą wzroku i słuchu, czyli tych zmysłów, które służą percepcji wrażeń oddalonych od człowieka. Wśród nich natomiast zdecydowana większość odnosi się do zjawisk związanych ze słyszeniem. Taki rezultat może zaskakiwać, jeśli przypomnimy, że pisarz odczuwał ogromny niedosyt wynikający z braku talentu muzycznego, zwłaszcza w otoczeniu muzyków i ludzi o wrażliwości muzycznej. Tak szeroka i bogata projekcja doznań typowych dla innych modalności na odbiór wrażeń dźwiękowych wynikać jednak może z dążenia do precyzyjnego przekazania brzmieniowych walorów otaczającego świata. Mając świadomość ograniczonej wiedzy muzycznej 
(w porównaniu z wiedzą z zakresu malarstwa), pisarz wykorzystuje te środki, którymi swobodnie i na wielką skalę posługuje się w odniesieniu do innych zjawisk o podłożu sensorycznym i z powodzeniem oddaje najdrobniejsze niuanse i odcienie dźwięków.

Co należy podkreślić, wśród zgromadzonego materiału dało się zaobserwować zaledwie po jednym przykładzie synestezyjnych modyfikacji doznań związanych z dotykiem i smakiem. 



\section{IDEOSTEZJA}

\section{Chromestezyjna obrazowość}

Jak powiedział Nabokov w wywiadzie dla BBC (w roku 1962) ${ }^{1}$, rzeczywistość jest subiektywna - jest nagromadzeniem informacji, ale nie jest do końca poznawalna. To, co dla jednych jest rzeczywistością, dla innych pozostaje tajemnicą:

Reality is a very subjective affair. I can define it as a kind of gradual accumulation of information; and as specialization. If we take a lily, for instance, $[\ldots]$ a lily is still more real to a botanist. And yet another stage of reality is reached with that botanist who is a specialist in lilies. You can get nearer and nearer, so to speak, to reality; but you never get near enough because reality is an infinite succession of steps, levels of perception, false bottoms, and hence unquenchable, unattainable.

Rzeczywistością dla pisarza, jego matki, żony i syna była synestezja - sposób percepcji dla wielu niedostępny. Temu szczególnemu rodzajowi postrzegania świata dał wyraz w poemacie $A n$ Evening of Russian Poetry ${ }^{2}$. Opowiada w nim grupie amerykań-

1 V. Nabokov, Strong Opinions, Vintage International, New York 1990, (również wersja on-line:) http://royallib.com/read/nabokov_vladimir/Strong_opinions.html\#0 [dostęp: 3.01.2015], s. 10-11.

2 V. Nabokov, Poems and Problems, McGraw-Hill Book Company, New York 1970, s. 158-159. 
skich studentek o poezji rosyjskiej, często odwołując się do synestezyjnych w swoim charakterze odczuć związanych z literami, głoskami, rytmem i prozodią:

The subject chosen for tonight's discussion

is everywhere though often incomplete:

when their basaltic banks become too steep, most rivers use a kind of rapid Russian, and so do children talking in their sleep.

My little helper at the magic lantern,

Insert that slide and let the colored beam

Project my name or any such-like phantom

In Slavic characters upon the screen.

The other way, the other way. I thank you.

On mellow hills the Greek, as you remember,

fashioned his alphabet from cranes in flight;

his arrows crossed the sunset, then the night.

Our simple skyline and a taste of timber, the influence of hives and conifers, reshaped the arrows and the borrowed birds.

Yes, Sylvia?

'Why do you speak of words

when all we want is knowledge nicely browned?'

Because all hangs together - shape and sound, heather and honey, vessel and content.

Not only rainbows - every line is bent, and skulls and seeds and all good worlds are round, like Russian verse, like our colossal vowels: those painted eggs, those glossy pitcher flowers that swallow whole a golden bumblebee, those shells that hold a thimble and the sea.

Next question.

'Is your prosody like ours?'

Well, Emmy, our pentameter may seem to foreign ears as if it could not rouse the limp iambus from its pyrrhic dream. 
But close your eyes and listen to the line.

The melody unwinds; the middle word is marvelously long and serpentine:

you hear one beat, but you have also heard the shadow of another, then the third touches the gong, and then the fourth one sighs.

It makes a very fascinating noise:

it opens slowly, like a grayish rose

in pedagogic films of long ago.

The rhyme is the line's birthday, as you know, and there certain customary twins

in Russian as in other tongues. For instance, love automatically rhymes with blood, nature with liberty, sadness with distance, human with everlasting, prince with mud, moon with a multitude of words, but sun and song and wind and life and death with none.

Beyond the seas where I have lost a scepter, I hear the neighing of my dappled nouns, soft participles coming down the steps, treading on leaves, trailing their rustling gowns, and liquid verbs in ahla and in ili, Aonian grottoes, nights in the Altai, black pools of sound with ,l"s for water lilies.

The empty glass I touched is tinkling still, but now 'tis covered by a hand and dies...

Synestezyjna obrazowość jest w poemacie na tyle oczywista, że - jak zauważa Donald Johnson - mogłaby być potraktowana niemal jako przypadek kliniczny ${ }^{3}$. Mamy tu z jednej strony litery nazwiska pisarza projektowane strumieniem barwnego światła na ekran, rozważania o mitycznym pochodzeniu liter alfabetu słowiańskiego (w domyśle - rosyjskiego) i ich kształcie zarysowanym

3 Д. Джонсон, Миры и антимиры Владимира Набокова, пер. Т. Стрелковой, Издательство Симпозиум, Санкт-Петербург, 2011, с. 5, on-line: http:// royallib.com/book/dgonson_donald/miri_i_antimiri_vladimira_nabokova.html [dostęp: 3.01.2015]. 
przez żurawie w locie, przez strzałę Greka przecinającą zachód słońca i noc, przez linię horyzontu i, co ciekawe, smak drewna. Angielskie „timber” (drewno) w wymowie amerykańskiej jest homofonem słowa „tibre” (dźwięk, barwa dźwięku, barwa). Zestawione przez Nabokova w warstwie brzmieniowej ze zmysłem smaku (a taste of timber/timbre), może przyczynić się do powstania wrażenia synestezyjnego odczucia smaku barwy dźwięku. Dalej Nabokov porównuje kształty samogłosek do wielkanocnych pisanek i do muszli wypełnionych morzem. Z drugiej strony, rytm wiersza rosyjskiego wywołuje szum porównywalny do otwierającej się powoli róży o szarawym odcieniu. Rymujące się zaś słowa tworzą nieprzypadkowe, wydawać by się mogło, zestawienia pojęć.

\section{Barwne postrzeganie liter}

O swojej zdolności synestezyjnego postrzegania świata $\mathrm{Na}-$ bokov otwarcie mówił w wywiadach. Zapytany podczas jednego z nich o powód, dla którego tak wielką wagę przywiązuje do kolorów, pisarz wyznał:

Color. I think I was born a painter - really! - and up to my fourteenth year, perhaps, I used to spend most of the day drawing and painting and I was supposed to become a painter in due time. But I don't think I had any real talent there. However, the sense of color, the love of color, I've had all my life: and also I have this rather freakish gift of seeing letters in color. It's called color hearing. Perhaps one in a thousand has that. But I'm told by psychologists that most children have it, that later they lose that aptitude when they are told by stupid parents that it's all nonsense, an A isn't black, a B isn't brown - now don't be absurd 4 .

Wspomnienia związane z synestezją sięgają wczesnego dzieciństwa pisarza. Są to jednak odczucia doświadczania czegoś normalnego i powszechnie znanego, tym bardziej że podobne doznania

4 V. Nabokov, Strong Opinions..., s. 17. 
były udziałem również jego matki. Dopiero w siódmym roku życia, podczas jednej z zabaw okazało się, że jego sposób „widzenia” liter i dźwięków różni się od tego, jak postrzega je matka:

Rzecz wyszła na jaw pewnego dnia, w moim siódmym roku życia, kiedy budowałem wieżę ze stosu starych klocków alfabetycznych. Wspomniałem matce mimochodem, że wszystkie kolory są dobrane niewłaściwie. Odkryliśmy wówczas, że niektóre jej litery mają to samo zabarwienie, co moje...5

Choć matka, a później również żona i syn Nabokova doświadczali zdolności „barwnego widzenia liter”, to odbierane przez nich światy znacznie się różniły, o czym Nabokov wspomina w wywiadzie:

[...] my wife has this gift of seeing letters in colors, too, but her colors are completely different. There are, perhaps, two or three letters where we coincide, but otherwise the colors are quite different. It turned out, we discovered one day, that my son, who was a little boy at the time - I think he was ten or eleven - sees letters in colors, too. Quite naturally he would say, "Oh, this isn't that color, this is this color," and so on. Then we asked him to list his colors and we discovered that in one case, one letter which he sees as purple, or perhaps mauve, is pink to me and blue to my wife. This is the letter M. So the combination of pink and blue makes lilac in his case. Which is as if genes were painting in aquarelle ${ }^{6}$.

Niezwykłość takiego postrzegania świata spowodowała, że w wywiadach proszono pisarza o podanie rzeczywistych przykładów doznań międzyzmysłowych. O tym, jakie kolory przybierają w jego umyśle litery inicjałów, mówi w wywiadzie dla BBC (1962 r.):

$\mathrm{V}$ is a kind of pale, transparent pink: I think it's called, technically, quartz pink: this is one of the closest colors that I can connect with the V. And the N, on the other hand, is a grayish-yellowish oatmeal color?

5 V. Nabokov, Pamięci, przemów. Autobiografia raz jeszcze, przeł. A. Kołyszko, posł. L. Engelking, Warszawskie Wydawnictwo Literackie MUZA SA, Warszawa 2004, s. 31.

6 V. Nabokov, Strong Opinions..., s. 17.

7 Ibidem. 
Jednakże barwne postrzeganie liter, a właściwie barwne widzenie słyszanych liter, nie było jedyną odmianą synestezji, doświadczaną przez pisarza. W Pamięci przemów Nabokov przyznał, że posiada dar, który określił jako „,słuch kolorystyczny”, choć, jak sam twierdził, określenie to nie jest zbyt trafne, ponieważ wrażenie kolorystyczne powstaje w procesie artykulacji danej litery, gdy wyobraża sobie jej kształt ${ }^{8}$. Szerzej o swych synestezyjnych skojarzeniach pisze w rosyjskiej wersji autobiografii Другие берега, odnajdując źródła doznań kolorystycznych w wyobrażeniach wrażeń wzrokowych, dotykowych i smakowych:

Не знаю, впрочем, правильно ли тут говорить о «слухе»: цветное ощущение создается по-моему осязательным, губным, чуть ли не вкусовым чутьем. Чтобы основательно определить окраску буквы, я должен букву просмаковать, дать ей набухнуть или излучиться во рту, пока воображаю ее зрительный узор 9 .

Słowa samego autora Lolity upoważniają nas do tego, by jako bodziec dla jego doznań barwnego postrzegania liter wskazać nakładające się na siebie doświadczenia wzrokowe, smakowe, dotykowe i słuchowe. Dalej zaś w tym samym tekście znajdujemy jeszcze jedną niezwykle istotną informację:

Чрезвычайно сложный вопрос, как и почему малейшее несовпадение между разноязычными начертаниями единозвучной буквы меняет и цветовое впечатление от нее (или, иначе говоря, каким именно образом сливаются в восприятии буквы ее звук, окраска и форма), может быть как-нибудь причастен понятию «структурных» красок в природе. Любопытно, что большей частью русская, инакописная, но идентичная по звуку, буква отличается тускловатым тоном по сравнению с латинской ${ }^{10}$.

8 V. Nabokov, Pamięci, przemów. Autobiografia raz jeszcze..., s. 30-31.

9 В. В. Набоков, Другие берега, [w:] Владимир Набоков. Собрание сочинений в четырех томах, под ред. В. В. Ерофеева, т. 4, Издательство «Правда», Москва 1990, s. 146.

10 Ibidem. 
Nabokov najwyraźniej zaobserwował u siebie zmianę postrzeganego odcienia litery pod wpływem każdej, nawet bardzo niewielkiej zmiany jej kształtu. O tym, że nie pozostawał obojętny na kształt liter, pisanych i drukowanych, świadczy szereg jego wspomnień, na przykład:

I learned to read English before I could read Russian. My first English friends were four simple souls in my grammar - Ben, Dan, Sam and Ned. [...] Wanfaced, big-limbed, silent nitwits, proud in the possession of certain tools („Ben has an axe"), they now drift with a slow-motioned slouch across the remotest backdrop of memory; and, akin to the mad alphabet of an optician's chart, the grammar-book lettering looms again before $\mathrm{me}^{11}$.

Kiedy opisywał swój zeszyt do dyktand z języka francuskiego, wspominał, że ,rozkoszując się każdą nóżką każdej klarownej litery", pieczołowicie kaligrafował słowo Dictée ${ }^{12}$. Podobnie też bohaterowie powieści skrupulatnie przedstawiają graficzne cechy znaków alfabetycznych. W Zaproszeniu na egzekucję Cyncynat przygląda się literom nieznanego sobie języka:

Мелкий, густой, узористый набор, с какими-то точками и живчиками внутри серпчатых букв, был, пожалуй, восточный, - напоминал чемто надписи на музейных кинжалах ${ }^{13}$..

Charakter zaś pisma M’sieur Pierre’a określił jako „барашком завитой почерк, лепота знаков препинания, подпись, как танец с покрывалом"14.

11 V. Nabokov, Speak, Memory: An Autobiography Revisited, Vintage International, Knopf Doubleday Publishing Group, New York, 2011, s. 16 [wersja on-line:] http://www.rulit.me/books/speak-memory-an-autobiographyrevisited-read-336809-16.html [dostęp: 13.02.2015].

12 Ibidem, s. 21; oraz: V. Nabokov, Pamięci, przemów. Autobiografia raz jeszcze..., s. 93.

13 В. В. Набоков, Приглашение на казнь, [w:] Владимир Набоков. Собрание сочинений в четырех томах.., т. 4, s. 71.

14 Ibidem, s. 67. 
Kształty liter Nabokov dostrzegał też w układach przestrzennych. Ścieżka w parku układała się w daszek wielkiej litery T, a jej pionową laskę tworzyła aleja smukłych dębów. Łazienka przeznaczona dla Mademoiselle w domu Nabokowów znajdowała się na końcu korytarza w kształcie litery $\mathrm{Z}^{15}$. Z kolei łazienka w Ardisie, miejsce spotkań Ady i Vana, miała kształt litery L ${ }^{16}$. Co więcej, litery w utworach Nabokova pełnią często funkcję nie tylko ilustracji graficznej, lecz również funkcję symboliczną. Tak jest na przykład w przypadku litery „„” w powieści Zaproszenie na egzekucję $e^{17}$ :

Не тут! Тупое «тут», подпертое и запертое четою «твердо», темная тюрьма, в которую заключен неуемно воющий ужас, держит меня и теснит. Но какие просветы по ночам, какое...

Cała zacytowana fraza została zbudowana wokół rosyjskiego «Тут», które oznacza świat więzienia i oczekiwania na egzekucję w przeciwieństwie do innego życia «там». Oprócz opozycji leksykalnej przedstawiającej istnienie dwóch światów, Johnson dostrzega tu również fonetyczną symbolikę szyku wyrazów w pierwszej części frazy: „Не тут! Тупое «тут» подпертое и запертое четою «твердо», темная тюрьма", zbudowanej na zasadzie aliteracji wyznaczonej przez kluczowe słowo «тут». W dalszej części natomiast nagromadzenie sześciu liter „У” między dwiema grupami po trzy litery „Т” pozwala utworzyć słowo ТТТУУУУУУТТТ, fonetycznie odpowiadające słowu «тут», będące jednocześnie krzykiem przerażenia ${ }^{18}$.

15 V. Nabokov, Pamięci, przemów. Autobiografia raz jeszcze..., s. 36, 97.

16 V. Nabokov, Ada or Ardor: A Family Chronicle, McGraw-Hill Book Company, New York-Toronto 1969, s. 144.

17 В. В. Набоков, Приглашение на казнь.., s. 53.

18 Więcej o tym i innych alfabetycznych ikonicznych obrazach w tekstach Nabokova patrz: D. B. Johnson, The Alpha and Omega of Nabokov's ,Invitation to a Beheading”, [w:] J. W. Connolly (ed.), Nabokov's , Invitation to a Beheading: A Critical Companion, Northwestern University Press, Evanston Ill. 1997, s. 119-140. 


\section{Kolorowy alfabet Nabokova}

O międzysensorycznych doznaniach towarzyszących procesowi percepcji liter alfabetu i odpowiadających im głosek u Nabokova wiemy bardzo dużo z dostarczonych przez niego samego informacji. Pisarz wspomina o różnicach w postrzeganej barwie jednakowo wymawianych, ale odmiennych w swej formie liter. Porównując doznania kolorystyczne liter alfabetu rosyjskiego i angielskiego, odcień tych pierwszych określa jako przytłumiony $\mathrm{w}$ porównaniu z ich angielskimi odpowiednikami brzmieniowymi. Czy jednak różnica między doznaniami barwnego widzenia poszczególnych liter tych dwóch alfabetów jest tak niewielka, skoro zasadnicze znaczenie w odbiorze wrażeń synestezyjnych ma kształt litery? Materiałem do rozstrzygnięcia tej kwestii będą rozważania Nabokova, który z typową dla synestetyka precyzją przybliża opis barw liter alfabetu rosyjskiego w tekście Другие берега, natomiast liter alfabetu łacińskiego w Speak, Memory ${ }^{19}$.

Zacznijmy od przedstawienia zmysłowych doznań skojarzonych z literami i głoskami alfabetu rosyjskiego ${ }^{20}$ :

1) Черно-бурая группа: густое, без галльского глянца, $\mathrm{A}^{21}$; довольно ровное (по сравнению с рваным R) P; крепкое каучуковое Г; Ж отличающееся от французского J, как горький шоколад от молочного; темно-коричневое, отполированное Я.

2) Белесная группа: буквы Л, Н, О, Х, Э представляют, в этом порядке, довольно бледную диету из вермишели, смоленской каши, миндального молока, сухой булки и шведского хлеба. Группу мутных промежуточных оттенков образуют клистирное Ч, пушисто-сизое Ш и такое же, но с прожелтью, Щ.

19 Opis barw liter alfabetu łacińskiego podaję na podstawie polskiego tłumaczenia autobiografii pisarza: V. Nabokov, Pamięci, przemów. Autobiografia raz jeszcze..., s. 30-31.

20 В. В. Набоков, Другие берега..., s. 146-147.

21 Sposób zapisu liter (wielkie litery alfabetu rosyjskiego i małe w cudzysłowie litery alfabetu łacińskiego) w dalszej części podaję zgodnie z ich zapisem w materiałach źródłowych, z których korzystam. 
3) Красная группа: вишнево-кирпичное Б (гуще, чем В); розово-фланелевое М; розовато-телесное (чуть желтее, чем V) В.

4) Желтая группа: оранжеватое Ё; охряное Е; палевое Д; светло-палевое И; золотистое У, латуневое Ю.

5) Зеленая группа: гуашевое П; пыльно-ольховое $\Phi$; пастельное Т (все это суше, чем их латинские однозвучия).

6) Синяя, переходящая в фиолетовое, группа: жестяное Ц; влажно-голубое $\mathrm{C}$; черничное К; блестяще-сиреневое 3.

Alfabetyczna tęcza wyglądałaby następująco: ВЁЕПСК3.

Podany w angielskiej wersji autobiografii wykaz obejmuje szereg angielskich (w znacznej przewadze) i francuskich głosek pogrupowanych w zależności od kojarzonych z nimi barw (i odniesień do rzeczywistości). Jak się okazuje, na doświadczany kolor wpływ ma nie tylko kształt liter, ale też długość trwania głoski i jej właściwości artykulacyjne ${ }^{22}$ :

1) The black group: the long „a" of the English alphabet has the tint of weathered wood, but a French „a" evokes polished ebony; hard „," - vulcanized rubber; ,r" - a sooty rag being ripped.

2) The white group: oatmeal „n”; noodle-limp „„”; ivory - backed hand mirror of „o" take care of the whites; the French „on”- the brimming tension-surface of alcohol in a small glass.

3) The blue group: steely „x", thundercloud „z”, huckleberry „k”; „q” is browner than , $\mathrm{k} " ;, \mathrm{s}$ " is not the light blue of ,,", but a curious mixture of azure and mother-of-pearl.

4) The green group: alder-leaf ,f”; the unripe apple of „,"; pistachio „t”; „w” - dull green, combined somehow with violet.

5) The yellow group: various ,e"s and „i"s; creamy „d”; bright-golden „y”, „u" - brassy with an olive sheen.

6) The brown group: the rich rubbery tone of soft „g"; paler ,"j”; the drab shoelace of "h".

7) The red group: „," has the tone called burnt sienna by painters; „m” is a fold of pink flannel; ,," - „Rose Quartz" in Maerz and Paul's Dictionary of Color.

Zestaw alfabetycznej tęczy w tym przypadku przedstawia się jako KZSPYGV.

22 V. Nabokov, Speak, Memory: An Autobiography Revisited ..., s. 6. 
Nabokov zauważa, że dźwięk i kształt w jego wyobrażeniach oddziałują na siebie, dlatego „q" jest dla niego ,bardziej brązowe niż , k”. Co więcej,

pokrewne barwy nigdy się nie zlewają, a dyftongi nie mają własnych, odrębnych kolorów, chyba że w innym języku wyraża je jedna litera (chociażby puszystoszara rosyjska litera „ш” na trzech nóżkach, tak stara jak nurty Nilu, która wpływa na obraz tego dźwięku w języku angielskim ${ }^{23}$.

Podsumujmy: z obserwacji autora Lolity wynika, że 1) dźwięk i forma liter (obok pozostałych doznań zmysłowych) odgrywają istotną rolę w powstawaniu wrażeń kolorystycznych; 2) choćby najdrobniejsza zmiana kształtu litery powoduje zmianę odcienia barwy doświadczanej podczas jej percepcji. Czy tak jest w istocie? Przekonajmy się o tym, zestawiając w jednej tabeli litery obydwu alfabetów o jednakowym lub zbliżonym brzmieniu, w drugiej zaś - litery zbliżone swoim kształtem.

Tabela 3

Zestawienie liter o jednakowym lub zbliżonym brzmieniu

\begin{tabular}{|c|c|c|c|}
\hline $\begin{array}{c}\text { Litera ła- } \\
\text { cińska/lite- } \\
\text { ra alfabetu } \\
\text { rosyjskiego }\end{array}$ & Brzmienie & $\begin{array}{l}\text { Grupa kolorystyczna i od- } \\
\text { cień litery łacińskiej }\end{array}$ & $\begin{array}{l}\text { Grupa kolorystyczna } \\
\text { i odcień litery alfabetu } \\
\text { rosyjskiego }\end{array}$ \\
\hline 1 & 2 & 3 & 4 \\
\hline \multirow{3}{*}{$\mathrm{A} / \mathrm{A}$} & $\begin{array}{l}\text { angielskie } \\
\text { długie [a:] }\end{array}$ & $\begin{array}{l}\text { grupa czarna } \\
\text { odcień suszonego drewna }\end{array}$ & \\
\hline & $\begin{array}{c}\text { francuskie } \\
{[\mathrm{a}]}\end{array}$ & $\begin{array}{l}\text { grupa czarna } \\
\text { gładki heban }\end{array}$ & \\
\hline & $\begin{array}{l}\text { rosyjskie } \\
{[\mathrm{a}]}\end{array}$ & & $\begin{array}{l}\text { grupa czarno-brunatna } \\
\text { odcień gęsty, bez połysku }\end{array}$ \\
\hline
\end{tabular}

23 V. Nabokov, Pamięci, przemów. Autobiografia raz jeszcze..., s. 30-31. Dalej polskie odpowiedniki angielskich barw podaję zgodnie z niniejszym tekstem autobiografii. 
Tab. 3 (cd.)

\begin{tabular}{|c|c|c|c|}
\hline 1 & 2 & 3 & 4 \\
\hline B / Б & {$[\mathrm{b}]$} & $\begin{array}{l}\text { grupa czerwona } \\
\text { sjena palona }\end{array}$ & $\begin{array}{l}\text { grupa czerwona } \\
\text { odcień wiśniowo-ceglasty } \\
\text { (gęstszy niż łacińskie B) }\end{array}$ \\
\hline C / Ц & [c] & $\begin{array}{l}\text { grupa niebieska } \\
\text { odcień bladoniebieski }\end{array}$ & $\begin{array}{l}\text { grupa niebieska } \\
\text { blaszany (odcień szarości) }\end{array}$ \\
\hline D / Д & [d] & $\begin{array}{l}\text { grupa żółta } \\
\text { odcień kremowy }\end{array}$ & $\begin{array}{l}\text { grupa żółta } \\
\text { odcień słomkowy }\end{array}$ \\
\hline E / Э & [e] & $\begin{array}{l}\text { grupa żółta } \\
\text { (brak dookreślenia) }\end{array}$ & $\begin{array}{l}\text { grupa biaława } \\
\text { odcień szwedzkiego chleba }\end{array}$ \\
\hline $\mathrm{F} / \Phi$ & [f] & $\begin{array}{l}\text { grupa zielona } \\
\text { odcień - liść olszyny }\end{array}$ & $\begin{array}{l}\text { grupa zielona } \\
\text { mętny odcień olchy }\end{array}$ \\
\hline \multirow[t]{2}{*}{$\mathrm{G} / \Gamma$} & $\begin{array}{l}\text { angielskie } \\
\text { miękkie } \\
\text { [g'] }\end{array}$ & $\begin{array}{l}\text { grupa brązowa } \\
\text { soczysty, gumowy dźwięk }\end{array}$ & \\
\hline & [g] & & $\begin{array}{l}\text { grupa czarno-brunatna } \\
\text { odcień kauczukowy }\end{array}$ \\
\hline $\mathrm{H} / \mathrm{X}$ & {$[\mathrm{h}]$} & $\begin{array}{l}\text { grupa brązowa } \\
\text { odcień burego sznurowadła }\end{array}$ & $\begin{array}{l}\text { grupa biaława } \\
\text { odcień suchej bułki }\end{array}$ \\
\hline І / И & [1] / [i] & $\begin{array}{l}\text { grupa żółta } \\
\text { (brak dookreślenia) }\end{array}$ & $\begin{array}{l}\text { grupa żółta } \\
\text { odcień jasnosłomkowy }\end{array}$ \\
\hline $\mathrm{K} / \mathrm{K}$ & {$[\mathrm{k}]$} & $\begin{array}{l}\text { grupa niebieska } \\
\text { czarna jagoda amerykańska }\end{array}$ & $\begin{array}{l}\text { grupa niebieska } \\
\text { odcień jagodowy }\end{array}$ \\
\hline L / Л & [1] / [1] & $\begin{array}{l}\text { grupa biała } \\
\text { odcień „kluchowaty” }\end{array}$ & $\begin{array}{l}\text { grupa biaława } \\
\text { odcień makaronu }\end{array}$ \\
\hline $\mathrm{M} / \mathrm{M}$ & {$[\mathrm{m}]$} & $\begin{array}{l}\text { grupa czerwona } \\
\text { odcień różowej flaneli }\end{array}$ & $\begin{array}{l}\text { grupa czerwona } \\
\text { odcień różowo-flanelowy }\end{array}$ \\
\hline $\mathrm{N} / \mathrm{H}$ & [n] & $\begin{array}{l}\text { grupa biała } \\
\text { odcień owsianki }\end{array}$ & $\begin{array}{l}\text { grupa biaława } \\
\text { odcień kaszy smoleńskiej }\end{array}$ \\
\hline $\mathrm{O} / \mathrm{O}$ & $\begin{array}{l}\text { brak szcze- } \\
\text { gółowych } \\
\text { inf. / [o] }\end{array}$ & $\begin{array}{l}\text { grupa biała } \\
\text { odcień jak lusterko opraw- } \\
\text { ne w kość słoniową }\end{array}$ & $\begin{array}{l}\text { grupa biaława } \\
\text { odcień mleczka migdało- } \\
\text { wego }\end{array}$ \\
\hline
\end{tabular}




\begin{tabular}{|c|c|c|c|}
\hline 1 & 2 & 3 & 4 \\
\hline Р / П & {$[\mathrm{p}]$} & $\begin{array}{l}\text { grupa zielona } \\
\text { odcień niedojrzałego jabłka }\end{array}$ & $\begin{array}{l}\text { grupa zielona } \\
\text { odcień gwaszowy (zie- } \\
\text { lony z dodatkiem bieli } \\
\text { kryjącej lub kredy) }\end{array}$ \\
\hline $\mathrm{R} / \mathrm{P}$ & {$[\mathrm{r}]$} & $\begin{array}{l}\text { grupa czarna } \\
\text { odcień poszarpanego osmo- } \\
\text { lonego łachmana }\end{array}$ & $\begin{array}{l}\text { grupa czarno-brunatna } \\
\text { odcień osmolonego łach- } \\
\text { mana }\end{array}$ \\
\hline $\mathrm{S} / \mathrm{C}$ & {$[\mathrm{s}]$} & $\begin{array}{l}\text { grupa niebieska } \\
\text { połączenie lazuru i macicy } \\
\text { perłowej }\end{array}$ & $\begin{array}{l}\text { grupa niebieska } \\
\text { odcień wilgotno-błękitny }\end{array}$ \\
\hline $\mathrm{T} / \mathrm{T}$ & {$[\mathrm{t}]$} & $\begin{array}{l}\text { grupa zielona } \\
\text { odcień pistacjowy }\end{array}$ & $\begin{array}{l}\text { grupa zielona } \\
\text { odcień pastelowy (bar- } \\
\text { dziej suchy) }\end{array}$ \\
\hline $\mathrm{U} / \mathrm{y}$ & $\begin{array}{c}\text { brak inf. } \\
\text { o długości } \\
\text { dźwięku / } \\
{[\mathrm{u}]} \\
\end{array}$ & $\begin{array}{l}\text { grupa żółta } \\
\text { mosiądz z oliwkowym po- } \\
\text { łyskiem }\end{array}$ & $\begin{array}{l}\text { grupa żółta } \\
\text { odcień złocisty }\end{array}$ \\
\hline U / Ю & [ju:] / [ju] & $\begin{array}{l}\text { grupa żółta } \\
\text { mosiądz z oliwkowym po- } \\
\text { łyskiem }\end{array}$ & $\begin{array}{l}\text { grupa żółta } \\
\text { odcień mosiądzu }\end{array}$ \\
\hline $\mathrm{V} / \mathrm{B}$ & {$[\mathrm{v}]$} & $\begin{array}{l}\text { grupa czerwona } \\
\text { róż kwarcowy }\end{array}$ & $\begin{array}{l}\text { grupa czerwona } \\
\text { odcień różowawo-cielisty }\end{array}$ \\
\hline W / Л & [uي $]$ / [1] & $\begin{array}{l}\text { grupa zielona } \\
\text { matowa zieleń z domiesz- } \\
\text { ką fioletu }\end{array}$ & $\begin{array}{l}\text { grupa biaława } \\
\text { odcień makaronu }\end{array}$ \\
\hline Y / ы & {$[\mathrm{j}],[1] /[\mathrm{y}]$} & $\begin{array}{l}\text { grupa źółta } \\
\text { odcień jaskrawozłoty }\end{array}$ & $\begin{array}{l}\text { grupa żółta } \\
\text { odcień jaskrawozłoty* }^{*}\end{array}$ \\
\hline $\mathrm{Z} / 3$ & {$[\mathrm{z}]$} & $\begin{array}{l}\text { grupa niebieska } \\
\text { odcień gradowej chmury }\end{array}$ & $\begin{array}{l}\text { grupa niebieska } \\
\text { odcień błyszczącego bzu }\end{array}$ \\
\hline
\end{tabular}

* Rosyjskie „b” graficznie przypomina połączenie dwóch liter. W tekście Nabokova nie znajdziemy informacji o kolorystycznych wrażeniach związanych z postrzeganiem tej litery. Wydaje się jednak, że można tu zastosować „regułę” dotyczącą dyftongów, która po sparafrazowaniu będzie brzmiała następująco: litery złożone nie mają własnych kolorów, chyba że w innym języku (znanym synestetykowi) wyraża je jedna litera. Przybierają wówczas kolor owej litery.

Źródło: opracowanie własne. 
Spośród dwudziestu czterech zestawionych par liter alfabetu rosyjskiego i łacińskiego przeważająca większość, aż dwadzieścia, jednakowo lub podobnie brzmiących (biorąc pod uwagę wymowę angielską) par należy do takiej samej grupy kolorystycznej. Wyjątek stanowią cztery pary: E / Э (gr. żółta / biaława), G / Г (brązowa / czarnobrunatna), H / X (brązowa / biaława) oraz W / Л (zielona / biaława). Przyglądając się jednak odcieniom barw doświadczanych w związku z tymi literami, zauważymy, że w dwóch pierwszych parach $(\mathrm{E} / \ni, \mathrm{G} / \Gamma)$, mimo przynależności do różnych grup kolorystycznych, mamy do czynienia ze zbliżonym do żółci odcieniem szwedzkiego chleba w pierwszym przypadku oraz ze zbliżonym do kauczukowego gumowo-brązowym odcieniem w drugim.

W pozostałych zilustrowanych parach liter dostrzec można dokładną zgodność kolorystyczną w jedenastu przypadkach. Co ciekawe, grupa ta obejmuje zarówno przykłady par liter tożsamych co do formy (K / K, M / M, O / O), jak i odmiennych (F / Ф, L / Л, N / H, P / П, R / P, U / Ю, V / B, Y / ы). Nasuwa się zatem wniosek, że aspektem decydującym w kwestii barwy danej litery jest odpowiadające jej brzmienie. Zastanawiać może jedynie para liter U / y, w przypadku której, mimo takiego samego brzmienia, litery w znacznym stopniu różnią się odcieniem. Czy zatem kształt litery pozostaje czynnikiem nieistotnym dla synestezyjnych doznań Nabokova?

Tabela 4

Zestawienie liter o jednakowym lub zbliżonym kształcie i odmiennym brzmieniu

\begin{tabular}{|c|l|l|}
\hline $\begin{array}{c}\text { Litera łacińska } \\
\text { / litera alfabetu } \\
\text { rosyjskiego }\end{array}$ & $\begin{array}{c}\text { Grupa kolorystyczna i od- } \\
\text { cień litery łacińskiej }\end{array}$ & $\begin{array}{c}\text { Grupa kolorystyczna i odcień } \\
\text { litery alfabetu rosyjskiego }\end{array}$ \\
\hline 1 & \multicolumn{1}{|c|}{2} & \multicolumn{1}{|c|}{3} \\
\hline $\mathrm{B} / \mathrm{B}$ & $\begin{array}{l}\text { grupa czerwona } \\
\text { sjena palona }\end{array}$ & $\begin{array}{l}\text { grupa czerwona } \\
\text { odcień różowawo-cielisty }\end{array}$ \\
\hline $\mathrm{b}] /[\mathrm{v}]$ & $\mathrm{g} / \mathrm{C}$ \\
{$[\mathrm{c}] /[\mathrm{s}]$} & $\begin{array}{l}\text { grupa niebieska } \\
\text { odcień bladoniebieski }\end{array}$ & $\begin{array}{l}\text { grupa niebieska } \\
\text { odcień wilgotno-błękitny }\end{array}$ \\
\hline
\end{tabular}




\begin{tabular}{|c|c|c|}
\hline 1 & 2 & 3 \\
\hline $\begin{array}{c}E / E \\
{[\mathrm{e}] /[\mathrm{je}]}\end{array}$ & $\begin{array}{l}\text { grupa żółta } \\
\text { (brak dookreślenia) }\end{array}$ & $\begin{array}{l}\text { grupa żółta } \\
\text { kolor ochry }\end{array}$ \\
\hline $\begin{array}{c}\mathrm{H} / \mathrm{H} \\
{[\mathrm{h}] /[\mathrm{n}]}\end{array}$ & $\begin{array}{l}\text { grupa brązowa } \\
\text { odcień bury }\end{array}$ & $\begin{array}{l}\text { grupa biaława } \\
\text { odcień kaszy smoleńskiej }\end{array}$ \\
\hline $\begin{array}{c}\mathrm{N} / \text { И } \\
{[\mathrm{n}] /[\mathrm{i}]}\end{array}$ & $\begin{array}{l}\text { grupa biała } \\
\text { odcień owsianki }\end{array}$ & $\begin{array}{l}\text { grupa żółta } \\
\text { odcień jasnosłomkowy }\end{array}$ \\
\hline $\begin{array}{c}\mathrm{P} / \mathrm{P} \\
{[\mathrm{p}] /[\mathrm{r}]}\end{array}$ & \begin{tabular}{|l|} 
grupa zielona \\
odcień niedojrzałego jabłka
\end{tabular} & $\begin{array}{l}\text { grupa czarno-brunatna } \\
\text { odcień osmolonego łachmana }\end{array}$ \\
\hline $\begin{array}{c}\mathrm{R} / \mathrm{g} \\
{[\mathrm{r}] /[\mathrm{ja}]}\end{array}$ & $\begin{array}{l}\text { grupa czarna } \\
\text { odcień poszarpanego osmo- } \\
\text { lonego łachmana }\end{array}$ & $\begin{array}{l}\text { grupa czarno-brunatna } \\
\text { ciemnobrązowe, wypolerowane }\end{array}$ \\
\hline $\begin{array}{c}\mathrm{Y} / \mathrm{Y} \\
{[\mathrm{y}] /[\mathrm{u}]}\end{array}$ & $\begin{array}{l}\text { grupa żółta } \\
\text { odcień jaskrawozłoty }\end{array}$ & $\begin{array}{l}\text { grupa żółta } \\
\text { odcień złocisty }\end{array}$ \\
\hline $\begin{array}{c}\mathrm{U} / \text { Ц } \\
{[\mathrm{u}] /[\mathrm{c}]}\end{array}$ & $\begin{array}{l}\text { grupa żółta } \\
\text { mosiądz z oliwkowym po- } \\
\text { łyskiem }\end{array}$ & $\begin{array}{l}\text { grupa niebieska } \\
\text { blaszany }\end{array}$ \\
\hline $\begin{array}{c}\mathrm{W} / \mathrm{W} \\
{[\mathrm{v}] /[\mathrm{sz}]}\end{array}$ & $\begin{array}{l}\text { grupa zielona } \\
\text { matowa zieleń z domiesz- } \\
\text { ką fioletu }\end{array}$ & $\begin{array}{l}\text { grupa biaława } \\
\text { odcień puszysto-szaro-niebieski }\end{array}$ \\
\hline
\end{tabular}

Źródło: opracowanie własne.

Połowa przedstawionych $\mathrm{w}$ tabeli par dotyczy liter należących do różnych grup kolorystycznych: $\mathrm{H}$ / $\mathrm{H}$ (brązowa / biaława), N / И (biała / żółta), P / P (zielona / czarno-brunatna), U / Ц (żółta / niebieska), W / Ш (zielona / biaława). Zauważmy, że są to pary tak jednakowych, jak i zbliżonych kształtem liter. W trzech przypadkach możemy mówić o dużym stopniu podobieństwa kolorystycznego: C / C (bladoniebieskie / wilgotno błękitne), E / E (żółć / ochra), N / И (odcień owsianki / jasnosłomkowy). Całkowita zbieżność widoczna jest natomiast w złocistym odcieniu liter Y / Y.

Obserwacje zaprezentowanych $\mathrm{w}$ tabelach zestawień skłaniają nas do wyciągnięcia następujących wniosków:

1) Jednakowy kształt i brzmienie liter w obydwu językach związane są z takimi samymi doznaniami kolorystycznymi; 
2) Zarówno brzmienie, jak i kształt litery mogą wpływać na rodzaj i jakość synestezyjnych wrażeń wzrokowych, choć większe znaczenie wydaje się mieć brzmienie. W przypadku zbieżności form liter, przy ich odmiennych właściwościach artykulacyjnych, zaledwie jedna para (Y / y) wywołuje jednakowe doznania kolorystyczne. O zbieżności barw liter tak samo lub podobnie brzmiących można natomiast mówić w odniesieniu do dwudziestu spośród dwudziestu czterech przykładów.

Uwagę warto zwrócić też na sposób opisu doznań kolorystycznych, charakterystyczny dla synestetyka. Nabokov nie posługuje się ogólnymi nazwami barw podstawowych. Nie pisze, że „o” jest białe, „r” czarne, a „,b” czerwone. Bardzo uważnie podaje odcienie każdego fonemu, by czytelnik mógł sobie wyobrazić jak najdokładniej to, czego pisarz doświadcza na co dzień. Odcienie przedstawione zostały zatem z dokładnością artysty malarza, który miesza farby w celu uzyskania określonego efektu (np. matowa zieleń z domieszką fioletu). Starania o jak największą precyzję skłoniły go też do wykorzystania porównań do przedmiotów, potraw i zjawisk najbliższego otoczenia człowieka, np.: Ж różni się od francuskiego J, jak gorzka czekolada różni się od mlecznej, $\mathrm{N}$ zaś ma odcień owsianki. Podobny sposób opisu barw pisarz zastosował w swoich utworach, na co wskazują choćby porównania w opowiadaniach:

пузырчатая вода цвета кофе с молоком

розовый, как миндальные лепестки

бледный, как гипсовая маска

белая, словно вылепленная из снегу

песочного цвета тучи

цвета стеклянных осколков, выглаженных волнами

Zauważmy też, że w opisach barwnego alfabetu pisarza nie brakuje typowo synestezyjnych zestawień wrażeń kolorystycznych ze słuchowymi: soczysty, nieco gumowy dźwięk miękkiego G, B - dźwięk zwany przez malarzy sjeną paloną. Określenie barw w kategoriach dźwięków potwierdza wagę czynnika słuchowego w kształtowaniu barwnego widzenia liter. 


\section{Pochodzenie synestezyjnych barw}

Rozważania dotyczące Nabokovowskiej ideostezji związanej z kolorem prowokują do zadania pytania o pochodzenie barw doświadczanych przez pisarza podczas percepcji liter i głosek. Przypomnijmy ${ }^{24}$, że istnieje kilka hipotez próbujących wyjaśnić to zjawisko $^{25}:$ 1) skojarzenia są wyuczane w dzieciństwie za pośrednictwem książek i zabawek, 2) mają charakter zjawisk „naturalnych”, 3) kolory są do pewnego stopnia „uczone” przez rodziców-synestetyków, 4) barwy są arbitralne.

W autobiografii Nabokov wspomina o literach alfabetu w kontekście zabawek z dzieciństwa:

Rzecz wyszła na jaw pewnego dnia, w moim siódmym roku życia, kiedy budowałem wieżę ze stosu starych klocków alfabetycznych. Wspomniałem matce mimochodem, że wszystkie kolory są dobrane niewłaściwie. Odkryliśmy wówczas, że niektóre jej litery mają to samo zabarwienie co moje, a ponadto, że nuty również kojarzą jej się optycznie ${ }^{26}$.

Ten fragment dostarcza nam informacji dotyczących dwóch wymienionych wcześniej potencjalnych źródeł kolorów. Synestezyjne skojarzenia Nabokova litera - barwa nie mogły się pojawić pod wpływem klocków z kolorowymi literami alfabetu, skoro barwy poszczególnych ich liter nie korespondowały z doznaniami siedmioletniego Wołodii. Jeśli z kolei kolorystyczne wrażenia byłyby

24 Szerzej problem pochodzenia skojarzeń synestezyjnych został omówiony w rozdziale pierwszym, w części Mechanizm i źródło synestezji.

25 P. Hancock, Synesthesia, alphabet books, and fridge magnets, [w:] J. Simner, E. M. Hubbard (eds), The Oxford Handbook of Synesthesia, Oxford University Press, Oxford 2013, ss. 83-100, wersja on-line: http://philpapers.org/rec/Hansab-2 [dostęp: 16.03.2014], s. 83.

26 V. Nabokov, Pamięci, przemów. Autobiografia raz jeszcze..., s. 31; patrz również: Б. Бойд, Владимир Набоков: русские годы, Симпозиум, 2010, wersja on-line: http://royallib.com/read/boyd_brayan/vladimir_nabokov_russkie_godi. html\#307200 [dostęp: 12.02.2015], s. 16. 
wyuczone przez matkę na podstawie jej doznań, to chłopiec nie dostrzegłby między nimi różnicy w odbiorze barw poszczególnych liter.

Badania naukowe dowodzą, że u osób dwujęzycznych wrażenia synestezyjne mogą zostać przeniesione z jednego języka na drugi $^{27}$. Mimo że Nabokov był Rosjaninem i Rosję opuścił dopiero w wieku dwudziestu lat, trudno określić, czy w jego przypad$\mathrm{ku}$ doznania kolorystyczne zostały przeniesione $\mathrm{z}$ liter alfabetu rosyjskiego na angielski, czy odwrotnie. Jak sam przyznaje, nauczył się czytać po angielsku, zanim umiał czytać po rosyjsku ${ }^{28}$. To jednak nie oznacza, że wcześniej nie miał styczności z rosyjskimi literami w książkach z biblioteki swojego ojca. Można założyć, że litery łacińskie były pierwszymi świadomie poznanymi przez małego Wołodię. Z pewnością natomiast pierwszymi słyszanymi i wypowiadanymi słowami były słowa języka rosyjskiego. Przez dom Nabokowów przewijało się wiele angielskich niań i guwernantek, które na co dzień mówiły do dzieci w swoim rodzimym języku ${ }^{29}$. Nic nie wskazuje jednak na to, by rodzice porozumiewali się z dziećmi w innym języku niż rosyjski. Sam Nabokov przyznał w wywiadzie udzielonym w roku 1962 dla telewizji BBC $^{30}$, że jego „,naturalnym” językiem jest język rosyjski ${ }^{31}$ :

My private tragedy, which cannot, indeed should not, be anybody's concern, is that I had to abandon my natural language, my natural idiom, my rich, infinitely rich and docile Russian tongue, for a secondrate brand of English.

27 Patrz: A. Mroczko-Wąsowicz, D. Nikolić, Colored alphabets in bilingual synesthets, [w:] J. Simner, E. M. Hubbard (eds), The Oxford Handbook of Synesthesia..., s. 165-180, wersja on-line: http://philpapers.org/rec/MROCAI [dostęp: 16.03.2014], s. 166; również: N. Witthoft, J. Winawer, Synesthetic colors determined by having colored refrigerator magnets in childhood, „Cortex”, 2006.

28 V. Nabokov, Pamięci, przemów. Autobiografia raz jeszcze..., s. 69.

29 Ibidem, s. 75-76.

30 V. Nabokov, Strong Opinions..., wywiad 2.

31 Patrz również: A. Ginter, Świat za stowami Vladimira Nabokova, Wydawnictwo Uniwersytetu Łódzkiego, Łódź 2003, s. 14-15. 
W tej jednak niezbyt oczywistej sytuacji trudno wskazać na język, który i w formie ustnej, i pisemnej odgrywałby rolę źródła dla transferu międzyjęzykowego.

Należy pamiętać, że obok kształtu i formy liter, jako elementy, które wpływają na wrażenia kolorystyczne Nabokov wymienia doznania smakowe i zapachowe towarzyszące wyobrażeniom danych liter, nie podając dalszych informacji. A zatem, choć opis w autobiograficznych tekstach Nabokova wnosi wiele światła w sposób widzenia świata przez pisarza, to pozostawia zarazem również niemało zagadek.

\section{Ideostezja w utworach Nabokova}

\section{Bohaterowie utworów wobec daru synestezji}

Przez pryzmat synestezyjnych współwrażeń Nabokov obserwował życie i konstruował świat swoich bohaterów, dzięki czemu nabrali oni realistycznych cech osób obdarzonych synestezją ${ }^{32}$. W większym lub mniejszym stopniu dzielą ze swym twórcą zdolność określoną przez niego jako audition colorée.

W Darze Fiodor Godunow-Czerdyncew w obszernym fragmencie rozmowy z Konczejewem bardzo szczegółowo opisuje odcienie niektórych liter:

К примеру: различные, многочисленные «а» на тех четырех языках, которыми владею, вижу едва ли не в стольких же тонах - от лаково-черных до занозисто серых - сколько представляю себе сортов поделочного дерева. Рекомендую вам мое розовое фланелевое «м». Не знаю, обращали ли вы когда-либо внимание на вату, которую изымали из майковских рам? Такова буква «ы», столь грязная, что словам стыдно начинаться с нее. Если бы у меня были под рукой краски, я бы вам так смешал sienne brûlée и сепию, что получился бы цвет гутаперчевого «ч»; и вы бы оценили мое сияющее «с», если я мог бы вам насыпать в горсть тех

32 Por: P. L. Duffy, J. Simner, Synaesthesia in fiction, „Cortex” 2010, nr 46/2, s. 277, wersja on-line: http://www.journals.elsevier.com/cortex [dostęp: 8.07.2013]. 
светлых сапфиров, которые я ребенком трогал, дрожа и не понимая, когда моя мать, в бальном платье, плача навзрыд, переливала свои совершенно небесные драгоценности из бездны в ладонь, из шкатулок на бархат, и вдруг все запирала, и никуда не ехала [...], и если отодвинуть в боковом окне фонаря штору, можно было видеть вдоль набережных фасадов в синей черноте ночи изумительно неподвижные, грозно алмазные вензеля, цветные венцы... - Buchstaben von Feuer [Огненные буквы], одним словом...33

Interesująco przedstawia się porównanie tego opisu z określeniami odcieni liter w autobiografii Pamięci przemów i Другие беpeza: „a” we wszystkich przypadkach należy do grupy czarnej lub odpowiadającej jej grupy czarno-brunatnej i odnosi się do odcieni drewna; „m” [«M»] Nabokova i jego bohatera ma barwę różowej flaneli; ,cz" [«ч»] jako kolor gruszki do lewatywy z autobiografii Nabokova z pewnością przypomina barwę uzyskaną w Darze z połączenia sjeny palonej i sepii. Natomiast «ы», przypomnijmy, w zestawieniu ujętym w książce Другие берега zostało pominięte. Skoro jednak pozostałe litery odpowiadają wrażeniom doświadczanym przez pisarza, to mamy prawo przypuszczać, że tak jest i w tym przypadku i «ы»w odczuciach autora powieści przybiera odcień „,brudnej waty wyjmowanej z ram okiennych”. A jeśli rzeczywiście tak jest, to wcześniejsze rozważania dotyczące wyprowadzenia barwy litery złożonej od barw litery jednakowo brzmiącej mogą okazać się błędne. Ponieważ nie możemy mieć pewności co do żadnej wersji, obydwie pozostawiamy w sferze hipotez.

Dalej w Darze, tym razem w polemicznym przedstawieniu poglądów Czernyszewskiego, bohatera książki Fiodora Godunowa-Czerdyncewa, po raz kolejny napotykamy zjawisko „,barwnego słyszenia”, tym razem w odniesieniu do Puszkina i Błoka:

Когда однажды, в 55 году, расписавшись о Пушкине, он захотел дать пример «бессмысленного сочетания слов», то привел мимоходом тут

33 В. В. Набоков, Дар, [w:] Владимир Набоков. Собрание сочинений в четырех томах, под ред. В. В. Ерофеева, т. 3, Издательство «Правда», Москва 1990, s. 68. 
же выдуманное «синий звук», - на свою голову напророчив пробивший через полвека блоковский «звонко-синий час». «Научный анализ показывает вздорность таких сочетаний», - писал он, - не зная о физиологическом факте «окрашенного слуха» ${ }^{34}$.

Jak pamiętamy, biografia Nikołaja Gawriłowicza Czernyszewskiego jest polemiką z przekonaniami Fiodora, prezentującego poglądy na literaturę bliskie poglądom Nabokova, podczas gdy koncepcje estetyczne głoszone przez Czernyszewskiego są z nimi całkowicie sprzeczne ${ }^{35}$. Dlatego przypadki synestezji uznane zostały w niej za „,bezmyślne połączenia słów”.

W tekstach autora Lolity znajdziemy jednak i taki przykład, w którym chromestezja została przedstawiona jako jednostka chorobowa, a doświadczający jej pacjent opisany z dużą dozą poczucia humoru ${ }^{36}$. Bohater $A d y$, doktor Van Veen, został poproszony o konsultacje w związku z przypadkiem chromestezji u Spencera Muldoona, czterdziestoletniego kawalera urodzonego bez oczu. Ów pacjent w atakach gwałtownej paranoi wykrzykiwał nazwy kształtów i substancji, które nauczył się rozpoznawać za pomocą dotyku. Dotyk pomógł mu też rozpoznawać kolory kredek przypadkowo pozostawionych w jego zasięgu przez pewnego studenta prowadzącego badania naukowe. Wyczuwał kolory tęczy, których nie mógł znać ani pamiętać z dzieciństwa:

[A research student - R.S.] happened to leave within Muldoon's reach one of those elongated boxes of new, unsharpened, colored-chalk pencils whose mere evocation (Dixon Pink Anadel!) make one's memory speak in the language of rainbows, the tints of their painted and polished woods being graded spectrally in their neat tin container. Poor Muldoon's childhood could not come to him with anything like such iridian recall, but when his groping fingers opened the box and palpated the pencils, a certain expression of sensual relish appeared on his parchment-pale face. Upon observing that the blind man's eyebrows went up slightly at red, higher at orange, still higher

\footnotetext{
34 Ibidem, s. 216.

35 Por.: L. Engelking, Posłowie, [w:] V. Nabokov, Dar..., s. 469.

36 V. Nabokov, Ada or Ardor: A Family Chronicle..., s. 468-470.
} 
at the shrill scream of yellow and then stepped down through the rest of the prismatic spectrum, R.S. casually told him that the woods were dyed differently - „red”, „orange”, „yellow”, et cetera, and quite as casually Muldoon rejoined that they also felt different one from another ${ }^{37}$.

Testy przeprowadzane na Muldoonie wykazały, że przesuwając palcami po kredkach, doświadcza on szeregu specyficznych doznań określonych jako 'parze' ${ }^{38}$, zbliżonych do mrowienia po kontakcie skóry z parzącą pokrzywą. Mówił o silnym zielonym parzu kawałka bibuły oraz mokrym słabym różowym parzu oddychającego nosa pielęgniarki Langford. Wyniki testów pokazały, że koniuszki palców Muldoona przekazują do jego mózgu „dotykową transkrypcję pryzmatycznego spektrum".

Taka diagnoza w żadnym stopniu nie odpowiada chromestezji, która jest rozumiana jako barwne słyszenie, a nie barwne dotykanie. Nie istnieją też żadne wzmianki w autobiograficznych tekstach Nabokova, które wskazywałyby na to, że opisane doznania Muldoona są doświadczane przez samego pisarza. Co więcej, pacjent z chromestezyjnymi dolegliwościami nie doszedł do siebie po kolejnym ataku paranoi i następującym po nim stanie odrętwienia, i zmarł zanim przewieziono go do Kingston w celu przeprowadzenia dalszych obserwacji. Wszystko to skłania nas do stwierdzenia, że Nabokov, z właściwym sobie poczuciem humoru, wykorzystał w powieści chromestezję jako termin medyczny na określenie jednostki chorobowej o podłożu synestezyjnym, powiązanej z tragicznymi, prowadzącymi do śmierci konsekwencjami.

\section{Ideostezyjna symbolika liter}

Bohater pierwszej napisanej w Stanach Zjednoczonych powieści Bend Sinister, filozof Adam Krug, mówi do nierozumiejącego jego słów Maksymowa:

37 Ibidem, s. 469.

38 W oryginale 'stingles'; tłumaczenie Leszka Engelkinga (V. Nabokov, Ada albo Żar. Kronika rodzinna, przeł. L. Engelking, Warszawskie Wydawnictwo Literackie MUZA SA, Warszawa 2009, s. 561. 
No subtlety of thought tainted his honesty, he was as reliable as iron and oak, and when Krug mentioned once that the word 'loyalty' phonetically and visually reminded him of a golden fork lying in the sun on a smooth spread of pale yellow silk, Maximov replied somewhat stiffly that to him loyalty was limited to its dictionary denotation ${ }^{39}$.

Ten synestezyjny obraz powstaje w międzysensorycznych doznaniach Nabokova, który pod wpływem dźwięku dwukrotnie pojawiającego się ,y” w wyrazie ,loyalty” (wrażenia 'fonetyczne') widzi kolor jaskrawozłoty, co nadaje słowu blask odbijających się promieni słonecznych. Wizualnie zaś litera ,y” zbliżona jest swym kształtem do widelca. Połączenie postrzeganych wrażeń dźwiękowych, graficznych i kolorystycznych tworzy niezwykły efekt w odniesieniu do pojęcia, które dla treści utworu ma kluczowe znaczenie. Adam Krug, osadzony przez Nabokova w świecie tyranii i okrucieństwa, w którym z łatwością dostrzec można echa II wojny światowej i ,porządku” radzieckiego po rewolucji roku $1917^{40}$, odmawia jakiejkolwiek współpracy z totalitarnymi władzami kraju. Ulega dopiero wtedy, gdy władze zabierają mu ukochanego syna, a po jego śmierci szantażują Kruga, oferując za współpracę wolność i życie uwięzionych wcześniej jego kolegów i przyjaciół. W takich okolicznościach lojalność nabiera szczególnej wartości, staje się tak cenna jak złoto, którego blaskiem lśni w skojarzeniach bohatera $i$ autora.

Interesująco przedstawia się też przykład z autobiografii Другие берега, w którym dopełniaczowa konstrukcja opisująca barwę ${ }^{41}$ sprawia wrażenie gry lub zagadki przygotowanej dla czytelnika:

39 V. Nabokov, Bend Sinister, Henry Holt and Company, New York 1947, s. 86.

40 Więcej na ten temat, patrz.: L. Engelking, Chwyt metafizyczny. Vladimir Nabokov - estetyka z sankcja wyższej rzeczywistości, Wydawnictwo UŁ, Łódź 2011, s. 252-259.

41 Więcej na temat konstrukcji dopełniaczowych określających kolor w utworach Nabokova: И. Н. Лукьяненко, Луна цъвета Ю: генитивньле конструкции со значением цвета у B. Набокова, «Вестник Балтийского федерального университета им. И. Канта» 2006, № 8, s. 34-39. 
Утреннюю неудачу иногда возмещала ловля в сумерки или ночью. На крайней дорожке парка лиловизна сирени, перед которой я стоял в ожидании бражников, переходила в рыхлую пепельность по мере медленного угасания дня, и молоком разливался туман по полям, и молодая луна цвета Ю висела в акварельном небе цвета $\mathrm{B}^{42}$.

Jak czytamy, podczas wieczorno-nocnego polowania na motyle księżyc w kolorze Ю wisiał na akwarelowym niebie w kolorze B. Z wcześniejszej informacji o barwach doświadczanych przez Nabokova pod wpływem kształtu liter i ich brzmieniowych ekwiwalentów dowiadujemy się, że Ю ma barwę mosiądzu, B zaś - różowo-cielistą, w odcieniu nieco bardziej żółtym niż różowe V. Kolory liter doskonale pasują do opisywanego wieczornego nieba z wyraźnie już zarysowanym księżycem w poświacie zachodzącego słońca. Co więcej, barwy nazwanych dźwięków nawiązują do kolorów kluczowych dla przedstawianej scenerii słów: złociste У w wyrazie ,луна” odpowiada mosiądzowemu Ю, a różowo-cielista barwa nieba została powtórzona w głosce B w słowie ,,акварельный"43.

Litera „O”, doświadczana przez pisarza jako synestezyjne wyobrażenie lusterka oprawionego w kość słoniową w języku angielskim oraz kolor migdałowego mleka w rosyjskim, okazała się przydatna w konstruowaniu ikonicznych obrazów. Jeden z rozdziałów autobiografii poświęcony jest nadwrażliwej szwajcarskiej guwernantce w domu Nabokowów, mademoiselle Cécile Miauton ${ }^{44}$, określonej w książce jako Mademoiselle O. Pierwotna jego wersja ${ }^{45}$

42 В. В. Набоков, Другие берега..., s. 208-209.

43 Por.: Д. Джонсон, Миры и антимиры Владимира Набокова..., s. 5.

44 Patrz: A. Pitzer, Ukryta historia Vladimira Nabokova, przeł. W. Górnaś, Warszawskie Wydawnictwo Literackie MUZA SA., Warszawa 2015, s. 46.

45 Nabokov napisał opowiadanie Mademoiselle $O$ po francusku. Po raz pierwszy zostało ono opublikowane przez czasopismo „Mesures” (Paryż, 1939). Wersja angielska powstała przy współudziale Hildy Ward i ukazała się w „Atlantic Monthly" oraz w zbiorze Nine Stories. Ostateczną, zmienioną wersję, bliższą autobiograficznej prawdy, pisarz zamieścił jako rozdział piąty swoich wspomnień Conclusive Evidence (1951), wydanych w Anglii pod tytułem Speak, Memory 
została opublikowana w formie opowiadania i tylko w nim, przed wprowadzeniem zmian autorskich, guwernantka pojawia się w złożonym synestezyjnym obrazie zimowego pejzażu:

Somehow those two sleighs have slipped away; they have left my imaginary double behind on the blue-white road. No, even the vibration in my ears is not their receding bells, but my own blood singing. All is still, spellbound, enthralled by that great heavenly $O$ shining above the Russian wilderness of my past. The snow is real, though, and as I bend to it and scoop up a handful, forty-five years crumble to glittering frost-dust between my fingers ${ }^{46}$.

Nadane przez Nabokova imię, zaokrąglona figura guwernantki, biel jej twarzy kojarzą się z księżycem, który w tekście pojawia się w postaci wielkiego niebiańskiego „O” (z jego podanymi wcześniej synestezyjnymi właściwościami), spajającego wszystkie te elementy. Lusterko oprawione w kość słoniową przypomina odbitym blaskiem księżyc, ten zaś kształt swój utożsamia z literą $\mathrm{O}$, obecną w imieniu Mademoiselle O.

Chromestezyjne cechy samogłoski „O” znalazły wyraz również w opowiadaniu Przewodnik po Berlinie:

Сегодня на снеговой полосе кто-то пальцем написал «Отто», и я подумал, что такое имя, с двумя белыми «о» по бокам и четой тихих согласных посередке, удивительно хорошо подходит к этому снегу, лежащему тихим слоем, к этой трубе с ее двумя отверстиями и таинственной глубиной ${ }^{47}$.

Jej kolor migdałowego mleka doskonale współgra z barwą śniegu, a zielone „T” kojarzy się z ciszą i jako nagłosowa spółgłoska

(1952). - V. Nabokov, List, który nigdy nie dotart do Rosji i inne opowiadania, t. 1, przeł. M. Kłobukowski, Warszawskie Wydawnictwo Literackie MUZA SA, Warszawa 2007, s. 416.

46 V. Nabokov, Mademoiselle $O$, [w:] V. Nabokov, The Stories of Vladimir Nabokov, Vintage Books, New York 1997, s. 482.

47 В. В. Набоков, Путеводитель по Берлину, [w:] В. В. Набоков, Полное собрание рассказов..., s. 206. 
w тишина, i jako barwa symbolizująca spokój, harmonię i równowagę ${ }^{48}$.

Kolejnym przypadkiem połączenia ikoniczności liter z ich chromestezyjną charakterystyką jest jedno z najwcześniejszych opowiadań pt. Burza. We wstępie do angielskiego przekładu opowiadań (Details of a Sunset and Other Stories, 1976) pisarz daje czytelnikowi szansę na wyobrażenie sobie doznań będących jego udziałem. Wyjaśnia anglojęzycznemu odbiorcy: „Piorun to po rosyjsku grom, burza - buria, a burza z piorunami - groza: wspaniałe słówko z błękitnym zygzakiem w środku" ${ }^{49}$. Rosyjskie „3” rzeczywiście swoim kształtem wyobraża zygzakowaty piorun podczas burzy, a jego chromestezyjne walory odpowiadające barwie błyszczącego bzu wzmacniają ten obraz, czyniąc go bardziej wyraźnym.

O przykładzie podwójnego określenia kolorystycznego można mówić w przypadku jedego z bohaterów $A d y$, Reda Veena, który został dwukrotnie opisany w tekście jako „czerwony” (,rudy" $)^{50}$. Z jednej strony, obok jego nazwiska pojawia się przymiotnik nazywający kolor ('red'). Z drugiej strony natomiast mamy inicjalne „V”, które należy do grupy czerwonej Nabokovowskich doznań.

\section{Kolorowe tony nazw}

Sirin

W czasie studiów w Cambridge Nabokov przyjął pseudonim, pod którym pisał i publikował swoje utwory aż do wyjazdu z Europy. Sirin - to odmiana białej sowy oraz mityczna postać z rosyjskich legend z głową i piersią kobiety, ale z ciałem ptaka. Siriny miały śpiewać piękne pieśni i przepowiadać szczęśliwą przyszłość. Były jednak niebezpieczne dla śmiertelników, którzy słysząc ich

48 S. Kopaliński, Stownik symboli, Oficyna Wydawnicza „Rytm”, Warszawa 2012, s. 498.

49 Podaję za: V. Nabokov, List, który nigdy nie dotart do Rosji i inne opowiadania, t. 1.., s. 405.

50 V. Nabokov, Ada or Ardor: A Family Chronicle..., s. 41. 
śpiew, zapominali o swych ziemskich sprawach, podążali za Sirinami i ginęli ${ }^{51}$.

Nie jest to jednak jedyny powód, dla którego pisarz posługiwał się takim właśnie pseudonimem. W rozmowie z Andrew Fieldem wyznał: „Я увидел псевдоним «Сирин» с очень ярким, светло-синим «с», золотистым «и», дрожаще-черным «р» и желтым «H»" ${ }^{52}$. Jak zauważył w swojej książce Donald Johnson ${ }^{53}$, barwy te są zbliżone do kolorów liter nazwiska pisarza: $\mathrm{H}$ - żółty, a - czarny, $\sigma$ - wiśniowo-ceglasty, o - białawy, $\mathrm{\kappa}$ - jagodowy, в - różowo-cielisty. Zbieżność dotyczyć będzie zatem barw c $-\kappa, и-\mathrm{H}$ oraz $\mathrm{p}-\mathrm{a}$.

\section{Tamara}

Również obraz pierwszej swojej miłości Nabokov przedstawił w autobiografii w chromestezyjny sposób:

Я впервые увидел Тамару - выбираю ей псевдоним, окрашенный в цветочные тона ее настоящего имени, - когда ей было пятнадцать лет, а мне шестнадцать ${ }^{54}$.

Kontekst okazuje się niewystarczający do wyjaśnienia, czy Nabokov ma tu na myśli namalowane barwy liter, czy doznania kolorystyczne pod wpływem słyszanych dźwięków. Donald Johnson uważa, że istnieją podstawy do tego, by słowo „окрашенный” rozumieć dosłownie, choć jednocześnie przyznaje, że nie bez znaczenia pozostaje fonetyczno-kolorystyczna charakterystyka imienia dziewczyny ${ }^{55}$. Jeśli założymy, że cały wyraz przyjmuje barwę pierwszej głoski, to zgodnie z ,kolorystycznym alfabetem” pisarza imię bohaterki wspomnień wywołuje wrażenie koloru zielonego, co jednak nie odpowiada różowemu odcieniowi pierwszej litery

\footnotetext{
51 Por.: V. Nabokov, Strong Opinions..., wywiad 15.

52 Cytuję za: Д. Джонсон, Миры и антимиры Владимира Набокова..., s. 5.

53 Ibidem.

54 В. В. Набоков, Другие берега..., s. 258.

55 Д. Джонсон, Миры и антимиры Владимира Набокова..., s. 5.
} 
imienia prawdziwej miłości pisarza (Валентина). Barwę imienia-pseudonimu możemy jednak ustalić w inny sposób - na podstawie opisu kolorów doświadczanych pod wpływem brzmienia wszystkich poszczególnych liter:

$\mathrm{T}-\mathrm{A}-\mathrm{M}-\mathrm{A}-\mathrm{P}-\mathrm{A}$

zielony pastelowy - czarny - różowo-flanelowy - czarny - czarny (odcień osmolonego łachmana) - czarny

Kolorem dominującym jest czerń z przebłyskami zieleni na początku i różu w środku. Kolorystyka imienia współgra z opisem miejsca pierwszego spotkania z dziewczyną ,w surowym, lecz swojskim plenerze wsi (czarna jodła, biała brzoza, torfowiska, łąki i nieużytki) tuż na południe od Sankt Petersburga" ${ }^{56}$. Nieprzypadkowo barwy te odpowiadają kolorystyce związanej z brzmieniem liter imienia Мария - tytułowej bohaterki pierwszej powieści Nabokova Машенька, zawierającej szereg elementów autobiograficznych, również odnoszących się do pierwszej miłości autora:

$\mathrm{M}-\mathrm{A}-\mathrm{P}-\mathrm{И}-\mathrm{Я}$

różowo-flanelowy - czarny - czarny (odcień osmolonego łachmana) - jasnosłomkowy - ciemnobrązowy

Nasuwa się jednak pytanie, czy barwy imion bohaterek utworów korespondują z rzeczywistym imieniem bohaterki wspomnień? W wieku szesnastu lat Wołodia poznał o rok młodszą Walentynę Jewgienijewnę Szulginę, która lato roku 1915 spędzała w wynajętej daczy we wsi Rożdiestwieno. Nazywał ją Lusią (Люcя). Ich znajomość przerodziła się w romans trwający jeszcze po powrocie do Petersburga i w kolejnym roku w Wyrze, dokąd wyjeżdżała rodzina Nabokowów ${ }^{57}$. Jeśli przypiszemy barwy i ich odcienie poszczególnym literom imion, to okaże się, że kolorystycznie imię Tamary współgra z imieniem Walentyny:

$\mathrm{B}-\mathrm{A}-\mathrm{J}-\mathrm{E}-\mathrm{H}-\mathrm{T}-\mathrm{U}-\mathrm{H}-\mathrm{A}$

różowawo-cielisty - czarny - białawy - ochra - białawy - zielony - jasnosłomkowy - ochra - czarny

56 V. Nabokov, Pamięci, przemów. Autobiografia raz jeszcze..., s. 206.

57 Patrz: L. Engelking, Chwyt metafizyczny. Vladimir Nabokov - estetyka z sankcją wyższej rzeczywistości..., s. 96. 
$\mathrm{B}-\mathrm{A}-Л-$ Я

różowawo-cielisty - czarny - białawy - ciemnobrązowy

Л - Ю - C - Я

białawy - odcień mosiądzu - błękitny - ciemnobrązowy.

W imionach Тамара, Мария oraz Валентина, Валя głównym kolorem jest czarny z przebłyskami różowego oraz jasnosłomkowego i/lub zielonego. Kryterium dla wyboru imienia w każdym omawianym przypadku literackim był zatem dominujący kolor wrażeń zmysłowych, korespondujący z barwami doznawanymi przez pisarza pod wpływem imienia pierwszej ukochanej.

\section{Zina}

Imię bohaterki Daru już po pobieżnym przeczytaniu tekstu zdaje się korespondować z określeniami umieszczonymi w jego otoczeniu:

Теперь (в этом белом, освещенном загончике, при золотистой близости Зины и при участии теплой вогнутой темноты, сразуза вырезным озарением петуний) он окончательно нашел в мысли о методах судьбы то, что служило нитью, тайной душой, шахматной идеей для едва еще задуманного «романа», о котором он накануне вскользь сообщал матери ${ }^{58}$.

Kolorystyczne cechy imienia przedstawiają się następująco: 3- И - H - A odcień błyszczącego bzu - jasnosłomkowy - ochra - czarny

Błyszcząca barwa nagłosowego ,3” w imieniu i jego powtórzenie w wyrazach золотистая близость, загончик oraz сразу за вырезным озарением, w połączeniu z ich znaczeniem blasku złocistej barwy, olśnienia i oświetlenia, pozwalają ujrzeć oczami wyobraźni ,złocistą bliskość bohaterki”.

Ada

Podobnie rzecz się ma z imieniem tytułowej bohaterki $A d y$, barwa którego została określona na podstawie koloru dominującej i dwukrotnie użytej samogłoski ,a”:

58 В. В. Набоков, Дар.., s. 327. 
„You can see the Tarn from the library window”, said Marina. „Presently Ada will show you all the rooms in the house. Ada?" (She pronounced it the Russian way with two deep, dark ,a"s, making it sound rather like ,ardour”) 59 .

Podwójne czarne ,a” nadaje całemu imieniu ciemną barwę. Jego ,głęboka, ciemna wymowa” ulega spotęgowaniu w słowie „,ardour” dzięki spółgłosce „,r” z grupy czarnej „,alfabetu” pisarza. Nie bez znaczenia pozostaje też czynnik semantyczny, który odnosi obydwa wyrazy do tytułu i głównego wątku powieści. Angielskie „,ardour” znaczy „,zapał, żar, ogień”, a w połączeniu z wrażeniem czarnej barwy określać może mroczne kazirodcze relacje między Adą i Vanem. Nieco dalej w tekście powieści znajdujemy potwierdzenie dla takiego rozumowania. Jest nim porównanie wspomnień percepcyjnych doznań Vana w czasie kontaktów z Adą do ciemnych płócien Rembrandta:

He learned her face. Nose, cheek, chin - all possessed such a softness of outline (associated retrospectively with keepsakes, and picture hats, and frightfully expensive little courtesans in Wicklow) that a mawkish admirer might well have imagined the pale plume of a reed, that unthinking man - pascaltrezza - shaping her profile, while a more childish and sensual digit would have liked, and did like, to palpate that nose, cheek, chin. Remembrance, like Rembrandt, is dark but festive ${ }^{60}$.

Jeszcze bliższym odniesieniem semantycznym imienia bohaterki będzie skojarzenie go z rosyjskim 'ад’ ('piekło”), na co wskazuje zresztą sama Ada, dostrzegając imię Vana zawarte w słowie „nirwana”: „I know there's a Van in Nirvana. I'll be with him in the depths moego ada, of my Hades" ${ }^{\prime 61}$.

Nazwy miejsc

W Lolicie Humbert nazywa swój świat Humberlandią: „She had entered my world, umber and black Humberland, with rash

\footnotetext{
59 V. Nabokov, Ada or Ardor: A Family Chronicle..., s. 39.

60 Ibidem, s. 103.

61 Ibidem, s. 583.
} 
curiosity..." ${ }^{62}$ Barwy liter nazwy, z przewagą odcieni brązu, żółci i czerni, układają się we wzór podpowiedziany przez narratora:

$\mathrm{H}-\mathrm{U}-\mathrm{M}-\mathrm{B}-\mathrm{E}-\mathrm{R}-\mathrm{L}-\mathrm{A}-\mathrm{N}-\mathrm{D}$

bury - mosiądzowy - różowy - sjena palona - żółty - czarny - biały - czarny - biały - kremowy

Kolor określony jako umbra zbliżony jest swym odcieniem do sjeny i ugru, przy czym ciepły, brązowawy odcień sjeny i złocistożółty oraz złocistobrunatny odcienie ugru w nazwie wymienionej przez Humberta doznawane są za pośrednictwem liter $\mathrm{H}, \mathrm{U}, \mathrm{B}$, E, D. Czarną barwę reprezentują litery $\mathrm{R}$ i A.

Podobnie w Splendorze wspomnienie Teneryfy budzi miłe, nostalgiczne skojarzenia, a sama nazwa określona została zielonym kolorem: „Тенериффа - Боже мой! - какое дивное зеленое слово!" 63 Czynnik semantyczny z pewnością nie pozostaje dla interpretacji bez znaczenia. Teneryfa, popularna wśród turystów wyspa na Oceanie Atlantyckim, wywołuje wyobrażenie miejsca ciepłego i pełnego roślinności. Okazuje się jednak, że i samo słowo wzbudzało u Nabokova doznania zielonej barwy, która dominuje wśród doświadczanych złotożółtych kolorowych liter, przeplatanych gdzieniegdzie czernią:

$\mathrm{T}-\mathrm{E}-\mathrm{H}-\mathrm{E}-\mathrm{P}-\mathrm{U}-\Phi-\Phi-\mathrm{A}$

zielony - ochra - białawy - ochra - czarno-brunatny - jasnosłomkowy - zielony - zielony - czarno-brunatny

Efekt zieleni został wzmocniony przez pisarza podwojeniem litery $\Phi$ o mętnym odcieniu olchy w nazwie, która w języku rosyjskim funkcjonuje jako Тенерифе.

W analogiczny sposób Nabokov wprowadza nazwę indyjskiego miasta:

62 V. Nabokov, Lolita, przeł. M. Kłobukowski, Wydawnictwo Da Capo, Warszawa 1997, s. 166.

63 В. В. Набоков, Подвиг, [w:] Владимир Набоков. Собрание сочинений в четырех томах, под ред. В. В. Ерофеева, т. 2, Издательство «Правда», Москва 1990, s. 155-296, s. 211. 
Приятель был у меня, он прослужил три года в Бомбее. Бомбей? Господи! Музыка географического названия. В одном этом слове есть что-то гигантское, солнечные бомбы, барабаны ${ }^{64}$.

Warstwa brzmieniowa nazwy, z powtórzonymi spółgłoskami wargowymi ,б” i „,м”, daje wrażenie muzycznego rytmu. Upodabnia ją też do słów „бомбы” і „барабаны”, z których ostatnie bezpośrednio odnosi się do muzyki i rytmu. Słoneczne barwy natomiast pochodzą ze wspomnień bohatera oraz z kolorystycznych właściwości fonemów: dwukrotne wiśniowo-ceglaste „Б”, różowy odcień „M”, „E” w kolorze ochry, „O” w odcieniu mleka migdałowego oraz jasnosłomkowe „Й”.

\section{Wielopłaszczyznowość skojarzeń ideostezyjnych}

W przypadku imienia tytułowej bohaterki Lolity i kreacji postaci jej bohaterów zauważyć można połączenie kolorystyki i światła z doznaniami słuchowymi, dotykowymi oraz skojarzeniami semantycznymi. Aspekty, które okazały się decydujące przy wyborze imienia Lolity Nabokov wyjaśnia w wywiadzie dla „Playboya” (1964) udzielonym Alvinowi Tofflerowi:

For my nymphet I needed a diminutive with a lyrical lilt to it. One of the most limpid and luminous letter is „L”. The suffix „-ita” has a lot of Latin tenderness, and this I required too. Hence: Lolita. However, it should not be pronounced as you and most Americans pronounce it: Low-lee-ta, with a heavy, clammy „L” and a long „o”. No, the first syllable should be as in „lollipop”, the „L” liquid and delicate, the „lee" not too sharp. Spaniards and Italians pronounce it, of course, with exactly the necessary note of archness and caress. Another consideration was the welcome murmur of its source name, the fountain name: those roses and tears in „Dolores”. My little girl's heartrending fate had to be taken into account together with the cuteness and limpidity. Dolores also provided her with another, plainer, more familiar and infantile diminutive: Dolly, which went nicely with the surname „Haze”, where Irish mists blend with a German bunny - I mean, a small German hare ${ }^{65}$.

${ }^{64}$ В. В. Набоков, Наташа, [w:] В. В. Набоков, Полное собрание расска3ов..., s. 142.

${ }^{65}$ V. Nabokov, Strong Opinions..., s. 25. 
Podobną myśl pisarz wyraził w rozmowie z Robertem Hughesem, gdy we wrześniu 1965 r. udzielał wywiadu dla 13. telewizyjnego programu edukacyjnego w Nowym Jorku:

Note that for the necessary effect of dreamy tenderness both „l"s and the „t” and indeed the whole word should be iberized and not pronounced the American way with crushed „l”s, a coarse „t”, and a long „," ...66

Tę artykulacyjną uwagę pisarz powtórzył w Adzie, gdzie wspominał o „lolicie” (damskiej odzieży), nazwanej tak od imienia andaluzyjskiej Cyganeczki w powieści Osberga, wymawianej z hiszpańskim, a nie angielskim , „" ${ }^{67}$. Nabokov podkreśla w niej namiętność wynikającą z brzmienia spółgłosek „„” i „„”, co wiąże się $\mathrm{z}$ faktem, że obydwie te litery i głoski obecne są w wyrazach little, light. Można zatem stwierdzić, że w doświadczanych wrażeniach nie bez znaczenia pozostaje czynnik lingwistyczny (fonologiczny i ortograficzny), chociaż główną rolę wydaje się odgrywać aspekt semantyczny.

Nagromadzenie „l” i ,„” zaobserwować możemy w pierwszych słowach powieści:

Lolita, light of my life, fire of my loins. My sin, my soul. Lo-lee-ta: the tip of the tongue taking a trip of three steps down the palate to tap, at three, on the teeth. Lo. Lee. Ta ${ }^{68}$.

Na symbolikę liter „l” i „v" oraz kojarzonych z nimi barw w powieści Prawdziwe życie Sebastiana Knighta wskazuje Johnson, który za oczywiste uważa użycie form tych liter w charakterze waginalnego i fallicznego obrazu graficznego ${ }^{69}$. Swój punkt widzenia uzasadnia fragmentem omawianej powieści:

\footnotetext{
66 Ibidem, s. 53.

67 Por. V. Nabokov, Ada albo Żar. Kronika rodzinna..., s. 101.

68 V. Nabokov, Lolita, Penguin Books, London 1995, s. 9.

69 Д. Джонсон, Миры и антимиры Владимира Набокова..., s. 9.
} 
Life with you was lovely - and when I say lovely, I mean doves and lilies, and velvet, and that soft pink , $\mathrm{v}$ " in the middle and the way your tongue curved up to the long, lingering ,l”. Our life together was alliterative, and when I think of all the little which will die, now that we cannot share them, I feel as if we were dead too [...] This is all poetry. I am lying to you. Lilly-livered ${ }^{70}$.

W synestezyjnych skojarzeniach barw i liter Nabokova „v" ma kolor różowy, a odcień „l” zbliżony jest do makaronu, co w kontekście wydarzeń w powieści wydaje się trafne.

Spostrzeżenia Johnsona można odnieść do zacytowanego wcześniej fragmentu Lolity, tym bardziej że w przypadku obydwu powieści mamy do czynienia $\mathrm{z}$ tematyką nawiązującą do relacji seksulanych, a barwna charakterystyka dotyczy tych samych spółgłosek. Ponadto przemawia za tym treść samej Lolity. Przypomnijmy, że zwiedzanie zabytków podczas wspólnych wojaży Humberta i Lolity obejmowało m.in. ,pink and lilac formations, Pharaonic, phallic, »too prehistoric for words« (blasé Lo)" "71. Falliczny kult bogów związanych z płodnością w starożytnym Egipcie polegał na umieszczaniu w świątyniach, przy drogach i placach symboli wyobrażających męski członek w stanie wzwodu i, czasami, odpowiadający mu symbol żeńskich narządów płciowych. Falliczne formacje w kolorze lila i różowym symbolizować zatem mogą męski członek i waginę.

\section{Ordinal linguistic personification}

W prozie Nabokova nie znajdziemy zbyt wielu przykładów odmiany ideostezji, która w literaturze naukowej określana jest jako ordinal linguistic personification. Pojawiają się wprawdzie skojarzenia inspirowane kształtem cyfr, jak w Patrz na te Arlekiny:

70 V. Nabokov, The Real Life of Sebastian Knight, wersja on-line: http:// www.rulit.me/books/the-real-life-of-sebastian-knight-read-152417-22.html [dostęp: 16.02.2015], s. 22 .

71 V. Nabokov, Lolita..., s. 156. 
I thought his secretary sounded a little grumpy on the phone; true, I declined to explain anything beforehand, beyond confiding to her, in an informal bantering manner, that the numeral ," " always reminded me of the flag an explorer sticks in the cranium of the North Pole ${ }^{72}$,

oraz w autobiografii Speak, Memory w jej angielskojęzycznym wydaniu:

I was born in April 1899, and naturally, during the first third of, say, 1903, was roughly three years old; but in August of that year, the sharp , 3" revealed to me (as described in „Perfect Past”) should refer to the century's age, not to mine, which was , „" and as square and resilient as a rubber pillow ${ }^{73}$.

A zatem z utworów Nabokova dowiadujemy się, że cyfra 7 przypominała mu flagę, natomiast 4 była dla niego tak kwadratowa i sprężysta jak gumowa poduszka. Pierwsze ze skojarzeń ma jednak rangę raczej porównania, aniżeli asocjacji synestezyjnej. W drugim przypadku natomiast można dostrzec cechy ideostezji: oprócz kształtu i być może barwy (guma kojarzy się z kolorem czarnym, jak w oponach samochodowych, lub brązowo-złotym ze względu na powiązanie z kauczukiem) mamy podaną właściwość materiału, tzn. sprężystość, co przydaje dynamiki i wrażenia ruchu, a tym samym ożywienia.

Interesującą wypowiedź znaleźć możemy w Darze. Jego bohater, Fiodor Konstantynowicz, tak pisze o dniach, które spędził ze swą ukochaną w mieszkaniu po wyjeździe gospodarzy:

Таким образом было решено, что с июля Зина останется одна в Берлине, продолжая служить у Траума, покамест Щеголев «не подыщет ей службы» в Копенгагене, куда она и приедет «по первому вызову» [...] Оставалось урегулировать вопрос квартиры. Продавать ее Щеголевым не хотелось, так что они стали искать, кому бы ее сдать. Нашли. Какой-то молодой немец [...] осмотрел квартиру - столовую, спальню,

72 V. Nabokov, Look at the Harlequins!, McGraw-Hill Book Company, New York 1974, s. 223.

${ }^{73}$ V. Nabokov, Speak, Memory: An Autobiography Revisited..., s. 2. 
кухню, Федора Константиновича в постели, - и остался доволен. Однако, квартиру он брал только с первого августа, так что еще в течение месяца после отъезда Щеголевых Зина и жилец могли в ней оставаться. Они считали дни: полсотни, сорок девать, тридцать, двадцать пять - каждая из этих цифр имела свое лицо: улей, сорока на дереве, силуэт рыцаря, молодой человек ${ }^{74}$.

Każda z podanych w tekście liczb ma swoją 'twarz': 50 to ul, 49 - sroka na drzewie, 30 - sylwetka rycerza, 25 - młody człowiek. Trudno wskazać jakąkolwiek motywację dla takiego opisu. Żadna z liczb nie przypomina swoim kształtem przedstawionego obiektu. Najbardziej prawdopodobnym wyjaśnieniem wydają się więc predyspozycje autora tekstu do postrzegania liczb w postaci obrazów prezentujących nie tylko sylwetki ludzi, ale też zwierzęta i przedmioty.

W czwartej części $A d y$, stanowiącej pełen metafor i porównań traktat o Czasie i Przestrzeni, znajdziemy z kolei wypowiedź, która prowokować może do rozważań nad innymi jeszcze aspektami doznań z grupy OLP:

The Past is changeless, intangible, and „never-to-be-revisited" - terms that do not fit this or that section of Space which I see, for instance, as a white villa and its whiter (newer) garage with seven cypresses of unequal height, tall Sunday and short Monday, watching over the private road that loops past scrub oak and briar down to the public one connecting Sorcière with the highway to Mont Roux (still one hundred miles apart) ${ }^{75}$.

Wysoka Niedziela i niski Poniedziałek stojący przy domu sugerować mogą, że Nabokov poddawał personifikacji również dni tygodnia. Ten przedstawiony w powieści obraz niewątpliwie znacznie rozszerza spektrum synestezyjnych i ideostezyjnych doznań doświadczanych przez pisarza.

74 В. В. Набоков, Дар..., s. 293.

75 V. Nabokov, Ada or Ardor: A Family Chronicle..., s. 544. 


\section{Podsumowanie}

Jak to wielokrotnie było już podkreślane, synestezja we wszystkich swoich odmianach stanowiła nieodłączną część Vladimira Nabokova - jego życia, widzenia świata i, co za tym idzie, twórczości. Wydaje się więc zrozumiałe, że doznania ideostezyjne wyznaczyły sposób kreacji świata przedstawionego w powieściach i opowiadaniach. $\mathrm{Z}$ jednej strony mamy w nich do czynienia $\mathrm{z}$ bohaterami obdarowanymi zdolnościami synestezyjnego współodczuwania lub cierpiącymi na przypadłość określoną mianem chromestezji. Z drugiej strony natomiast odcieniami doświadczanych barw Nabokov przedstawia obrazy malowane przez dźwięki odpowiadające poszczególnym głoskom i literom.

Zwykle zabiegi te służą uwydatnieniu treści niesionych przez słowa oraz spotęgowaniu siły ich oddziaływania na czytelnika, jak w przypadku skojarzenia słowa „loyalty” ze złotym widelcem. Niekiedy jednak stają się one elementem gry pisarza z czytelnikiem, swoistą zagadką, rozwiązanie której warunkuje zrozumienie treści utworu. Barwne litery traktowane są jak symbole tworzące tło dla rozgrywających się wydarzeń lub dla przeżyć i stanów emocjonalnych bohaterów. A za owymi symbolami kryć się mogą na przykład kolory nieba rozświetlonego promieniami zachodzącego słońca. Najczęściej jednak „kolorowy alfabet” Nabokova znajduje swój wyraz w barwnych tonach imion bohaterów i wykorzystywanych w tekstach nazw miejscowości. Z kolei do sporadycznych zaliczyć trzeba określenia i opisy doznań kolorystycznych inspirowanych kształtem cyfr / liczb czy dniami tygodnia, choć niewątpliwie należą one do wrażeń najbardziej efektownych. 



\section{METAFORA SYNESTEZYJNA}

\section{Synestezja jako synteza sztuk}

W literaturze, poezji, malarstwie, synestezja stosowana jest jako środek wyrazu artystycznego w technice symbolizmu w celu transpozycji wrażeń, szczególnie w okresie dekadenckim przełomu XIX i XX w., jak zauważa Aleksandra Rogowska w artykule Czy synestetycy sa wśród nas ${ }^{1}$. Synestezja odgrywała wówczas istotną rolę w kontekście syntezy i jedności sztuk. Mówiło się wówczas na przykład o muzyczności malarstwa i poezji czy o malarskości muzyki.

Synestezja znana była jednak w sztuce już dużo wcześniej. W wieku XVI włoski malarz Giuseppe Arcimboldo (1527-1593) był wynalazcą systemu kolorów do zapisu nutowego. Melodie, które muzyk odgrywał na klawiszach, Arcimboldo próbował przedstawić w postaci kolorowych plam². Eksperymentował w ten sposób z oddawaniem na płótnie dźwięków, przy czym stosował odrębne barwy dla poszczególnych głosów kompozycji muzycznej i pracował nad powiązaniem koloru, dźwięku i światła ${ }^{3}$.

1 A. Rogowska, Czy synestetycy są wśród nas?, „Modelowe Nauczanie” 2004, nr 7, s. 35.

2 Por.: Giuseppe Arcimboldo. Biografia, http://www.arcimboldo.art.pl/old/ index 1.htm [dostęp: 20.01.2015]

3 K. Stępień-Kutera, Bieguny manieryzmu - muzyczność i retoryka, „Res Facta Nova" 2007, nr 9 (18), wersja on-line: http://www.resfactanova.pl/pliki/ archiwum/numer_18/RFN18\%20Stepien-Kutera\%20-\%20Bieguny\%20manieryzmu.pdf [dostęp: 21.01.2015], s. 21. 
Połączenie technik i doznań muzycznych z malarskimi było też celem twórczości i działalności francuskiego malarza Eugène Delacroix (1798-1863), jednego z najwybitniejszych przedstawicieli romantyzmu w sztuce europejskiej. Delacroix był twórcą wszechstronnie uzdolnionym, miłośnikiem i znawcą muzyki (w młodości uczył się śpiewu i gry na skrzypcach). Jego koncepcja sztuki zainspirowana była ideą epoki w estetyzującym nurcie correspondance des arts, co prowadziło go do poszukiwania analogii między muzyką i malarstwem oraz promowania malarsko-muzycznej dynamiki barw, pionierskich dokonań w zakresie „dźwięczności”, „modulacji” koloru czy „harmonii” tonów ${ }^{4}$. Muzyczne malarstwo Delacroix jest jaskrawym przykładem syntezy sztuk, rozumianej jako wzajemna ich inspiracja oraz transpozycja motywów wyrażonych językiem jednej ze sztuk na język innej sztuki ${ }^{5}$.

Kolejnym przykładem muzyka-niesynestetyka łączącego doznania koloru i dźwięku jest Aleksander Nikołajewicz Skriabin (1872-1915), który skomponował symfonię na orkiestrę z fortepianem, chór i fortepian świetlny, zatytułowaną Prometeusz: Poemat ognia. Fortepian świetlny zamiast dźwięków wydawał refleksy świetlne, przy czym każdemu klawiszowi przyporządkowany był ściśle określony kolor 6 . Ideą Skriabina było też, by podczas wykonania utworu publiczność była ubrana na biało. Dzięki temu barwy odbijały się od ich postaci i mogły zawładnąc całą przestrzenią․ Tak spektakularne wykonanie zapisało się w historii sztuki dzięki połączeniu efektów słuchowych i wizualnych, a w historii muzyki - istnieniem tradycyjnego zapisu nutowego dla instrumentów i chóru oraz osobnego zapisu nutowego dla kolorów.

4 Patrz: B. Weber, Eugène Delacroix, Narodowy Instytut Fryderyka Chopina, 2010, http://pl.chopin.nifc.pl/chopin/persons/detail/id/2692 [dostęp: 27.01.2015].

5 A. Sadkowska, Synteza sztuk we francuskim romantyzmie i symbolizmie, http://biesiada.polon.uw.edu.pl/symbolizm.pdf [dostęp: 27.01.2015].

6 Skriabin i jego fortepian świetlny były przedmiotem szerszych rozważań w części poświęconej historii badań nad synestezją.

7 P. Nierobisz, Interaktywne projekcje $i$ wizualizacje (VJing) w kontekście filmowym, 2012, s. 18, http://www.visuals.pl/interaktywneProjekcje.pdf [dostęp: 21.01.2015]. 
Na uwagę zasługuje też postać Renè Ghila (1862-1925), belgijskiego symbolisty, który dążył do stworzenia syntetycznego dzieła łączącego w sobie elementy różnych sztuk. W nowym typie poezji słowo, sens i ekspresja muzyczna miały sobie wzajemnie odpowiadać. Ghil wierzył, że samogłoskom można przypisać kolory, co zawarł w swojej teorii barwnego słyszenia ${ }^{8}$. Odniósł się też do sonetu Rimbauda Samogłoski, w którym poeta przypisuje barwy poszczególnym głoskom, modyfikując jednak te korelacje zgodnie z własnymi odczuciami: twierdził, że A wciąż jest czarne, E białe, ale I z czerwonego zmienia się w niebieskie, $\mathrm{U}$ z zielonego w żółte, a $\mathrm{O}$ z błękitnego w czerwone. Na tym jednak nie koniec. Odpowiedniości barwne Ghil przeniósł na sferę instrumentalną. Każdej samogłosce, a więc i każdej barwie, przypisał odpowiedni instrument muzyczny: A - organy, E - harfa, I - skrzypce, O - instrumenty dęte, $\mathrm{U}$ - flet. Wokół tych typów instrumentów, na podstawie symbolicznych powinowactw, miały się grupować spółgłoski: np. wokół skrzypcowego niebieskiego I miały się gromadzić wyostrzone $\mathrm{S}$ i Z, błagalne V, miękkie i płaczące $\mathrm{L}^{9}$.

Wszystkie podane przykłady twórców pokazują, że sztuka poszukuje rozmaitych dróg łączenia swych elementów, by znaleźć jedność w rozmaitości i z większą mocą docierać ze swym przesłaniem do odbiorcy - widza, słuchacza, czytelnika. Pomocna w tym względzie okazuje się synestezja i zbliżona do niej synteza wrażeń zmysłowych.

\section{Synestezja a metafora synestezyjna}

Język sztuki, w tym sztuki literackiej, oparty jest na stosowaniu porównań, skojarzeń, metafor. Jak zauważa Rogowska, zdolność do tworzenia odległych asocjacji, która cechuje zwłaszcza

8 A. Sadkowska, Synteza sztuk we francuskim romantyzmie i symbolizmie..., s. 3.

9 R. Ghil, Traktat o słowie, Paryż 1978, s. 109; podaję za: A. Sadkowska, Synteza sztuk we francuskim romantyzmie i symbolizmie..., s. 3. 
jednostki twórcze i jest wykorzystywana w ich pracy artystycznej, wydaje się stanowić cechę charakterystyczną ludzkiego umysłu. Częste występowanie synestezji wśród artystów łączyć się może, jej zdaniem, ze szczególnymi predyspozycjami do łatwego i częstego posługiwania się metaforą, analogią czy odległą asocjacją ${ }^{10}$. Dla synestetyka jednak metafora jest dosłownością. Powiązania dźwięków z barwami, barw z zapachami, smaków z właściwościami dotykowymi mają dla niego charakter permanentny i towarzyszą mu przez całe życie niezależnie od jego woli, dokładając do postrzeganej przez niego rzeczywistości nieistniejące w niej jakości ${ }^{11}$. Trudno się z tym nie zgodzić, skoro doznania synestezyjne przeważnie są mimowolne i trwałe. W przypadku Nabokova mamy jednak do czynienia nie tyle z synestetykiem, ile z synestetykiem - pisarzem, który metaforę, również tę opartą na związkach intersensorycznych, wykorzystuje w sposób świadomy dla osiągnięcia estetycznych założeń literackich. Nierzadkie w jego utworach są zatem przykłady synestezji rozumianej nie jako dosłowność, lecz jako metafora.

Przyznać należy, że postawienie granicy między synestezją i metaforą międzymodalną czy asocjacją bywa niezmiernie trudne. Obok wspomnianej wyżej trwałości wrażeń synestezyjnych, Rogowska wymienia kilka kolejnych czynników, które mają pozwolić na ich rozróżnienie. Kryteria te są tożsame lub przynajmniej ściśle związane z cechami doznań synestezyjnych wymienionymi przez Cytowica, a wspomnianymi w rozdziale pierwszym:

1. Synestezja łączy proste doznania na niskim, percepcyjnym poziomie umysłowego przetwarzania informacji (kolor, dźwięk, dotyk, smak, zapach); asocjacje zwykle łączą złożone obrazy umysłowe, pośredniczone przez indywidualne, sytuacyjne mechanizmy pamięciowe, semantyczne znaczenie bodźców, konotacje kulturowe itd.

2. Synestezja jest mimowolna i automatyczna, towarzyszy percepcji bodźca fizycznego; asocjacje są świadome, umyślne i do-

10 A. Rogowska, Czy synestetycy sa wśród nas? ..., s. 36.

11 A. Rogowska, Zwiąki synestezji z muzyka, ,„Muzyka” 2002, nr 1, s. 85. 
browolne, mogą występować dowolnie i niezależnie od percepcji.

3. Synestezje nie zmieniają się w ciągu życia jednostki; asocjacje są zmienne, zależne od czynników, które modyfikują skojarzenia i konotacje, takich jak doświadczenie, wiedza, kultura, aktualna sytuacja, nastrój, stan psychofizyczny.

4. Synestetyk nie potrafi wyjaśnić, dlaczego pojawiają się u niego takie właśnie skojarzenia; w przypadku asocjacji osoby są zwykle świadome źródła ich powstania (pośrednictwo emocjonalne, mechanizmy pamięciowe, styczność w czasie, podobieństwo, kontrast itd. $)^{12}$.

Mimo istnienia jasnych, jak by się zdawało, kryteriów oddzielających metaforę synestezyjną od doznań synestezyjnych, w wielu przypadkach trudno jest ocenić z całkowitą pewnością, czy metafora jest rezultatem synestezyjnego postrzegania rzeczywistości przez autora, czy też jego celowym zabiegiem pisarskim. Dość liczną grupę wśród zgromadzonego materiału tworzą jednak te przykłady, które nie wpisują się w założenia przyjęte dla synestezji w sensie neuropsychologicznym, a bardziej odpowiadają tzw. synestezji literackiej, w której skojarzenia międzyzmysłowe wykorzystywane są dla lepszego dookreślenia niektórych zjawisk, odczuć czy myśli $i^{13}$. Określenia typu słodki głos, ciepła barwa, chłodne spojrzenie, są w powszechnym użyciu. Nie brakuje ich też u Nabokova.

\section{Uniwersalne doświadczenia synestezyjne}

Badania i obserwacje potwierdziły istnienie ogólnych tendencji kojarzenia dźwięku z barwą niemuzyczną, o czym pisze dalej w swoim artykule Rogowska. Muzyka o charakterze radosnym i szybkim tempie kojarzona jest zwykle z barwami czystymi, jasnymi i jaskrawymi, natomiast wolna, nostalgiczna muzyka refleksyjna odpowiada barwom pastelowym, wyblakłym, zabrudzonym

12 A. Rogowska, Czy synestetycy squ wśród nas?..., s. 34.

13 A. Rogowska, Zwiąki synestezji z muzyką..., s. 85. 
i ciemnym. Tonacje krzyżykowe określane są jaskrawymi, ostrymi, „krzykliwymi” i błyszczącymi kolorami, tonacje zaś bemolowe - z ciemnymi, ciepłymi, „spokojnymi”, matowymi. W konsekwencji tonacja Fis-dur wywoła zupełnie inne skojarzenia niż Ges-dur, chociaż bezwzględna wysokość dźwięków w obu przypadkach jest jednakowa. Badania wykazały, że te same osoby reagowały inaczej na dźwięki, gdy je nazywano niż w przypadku, gdy nie podawano ich nazwy, np. dźwięk des miał inny kolor niż cis. Na ich wrażenia synestezyjne mogły mieć wpływ podświadome skojarzenia wysokich (podwyższonych) dźwięków z jasnością (rozjaśnieniem) i niskich (obniżonych) dźwięków z ciemnością (ściemnieniem). Tego rodzaju skojarzenia występują u wszystkich ludzi w jednakowy sposób ${ }^{14}$.
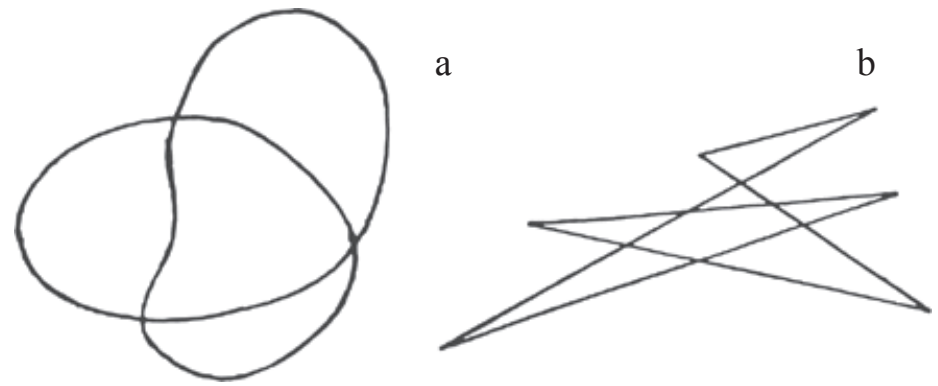

\section{Ilustracja 7. Powiązania międzymodalne: test takete (figura b) / baluba}

(figura a)

W. Köhler, Gestalt Psychology, Liveright, New York 1929, s. 225

Źródło grafiki: M. Kubovy, M. Yu, Multistability, cross-modal binding and the additivity of conjoined grouping principles, „Philosophical Transactions of The Royal Society B" 2012, vol. 367, s. 955, http://rstb.royalsocietypublishing. org/content/367/1591/954 [dostęp: 3.06.2015]

Interesujący eksperyment przeprowadził w tym zakresie Wolfgang Köhler ${ }^{15}$. Na hiszpańskojęzycznej Teneryfie przygotował on

14 Ibidem, s. 88.

15 W. Köhler, Gestalt Psychology, Liveright, New York 1947; podaję za: M. Senderecka, Synestezja - od psychofizjologicznych badań do filozoficznych im- 
dwie figury (ukazane niżej) i poprosił badanych o dopasowanie ich do wyrazów „takete” i „baluba” (,malum” w wersji z roku 1947).

Niemal wszyscy przyporządkowali słowo „takete” do kształtu o ostrych konturach, „baluba” zaś do figury o obłym kształcie. Później eksperyment ten powtórzyli Vilayanur Ramachandran i Edward Hubbard, zamieniając wyrazy na ,kiki” i „bouba”.
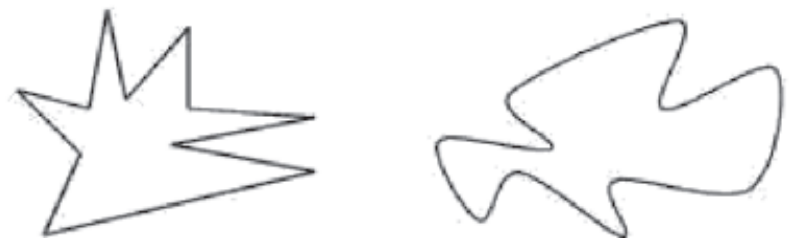

\section{Ilustracja 8. Powiązania międzymodalne: test kiki / bouba}

V. S. Ramachandran, E. M. Hubbard, Synaesthesia - A Window Into Perception, Thought and Language, „Journal of Consciousness Studies” 2001, vol. 8, No 12, s. 19

Źródło grafiki: W. Bucci, S. Murphy, Symbolic and Subsymbolic, The Referential Process, http://www.thereferentialprocess.org/theory/symbolic-subsymbolic [dostęp: 5.06.2015]

Rezultat był podobny do wcześniejszego: 95\% uczestników wyrazem „kiki” nazwało figurę po lewej stronie, a figurę po prawej - wyrazem „bouba"16. Stało się tak, ponieważ wizualnie ostre zmiany kierunku linii figury po lewej stronie korespondują z odbieraną jako ostra artykulacją wyrazu „kiki” i krótkimi („ostrymi”) uderzeniami języka w podniebienie.

plikacji, [w:] S. Wszołek, R. Janusz (red.), Wyzwania racjonalności, Wydawnictwo WAM, Kraków 2006, s. 259-278, wersja on-line: www.kognitywistyka.upjp2. edu.pl/resources/artykuly/sender1.pdf'[dostęp 20.08.2013], s. 274.

16 V. S. Ramachandran, E. M. Hubbard, Synaesthesia - A Window Into Perception, Thought and Language, „Journal of Consciousness Studies” 2001, vol. 8, No 12, wersja on-line: http://cbc.ucsd.edu/pdf/Synaesthesia\%20-\%20JCS. pdf [dostęp: 3.02.2015], s. 19. 
Rezultat eksperymentu może sugerować, że ludzie posiadają wrodzoną zdolność do kojarzenia pewnych dźwięków z określonymi kształtami ${ }^{17}$. Co więcej, jak zauważyli Ramachandran i Hubbard, ruchy warg i języka można synestezyjnie skojarzyć z obiektami, do których się odnoszą. Przykładem mogą być niektóre przymiotniki nazywające „coś małego": little, petite, teeny, diminutive, artykulacji których towarzyszy zwężenie warg, w przeciwieństwie do przymiotników enormous i grand ze średnim i szerokim ułożeniem warg. Można powiedzieć, że ruchy warg imitują charakter postrzeganych bodźców. Zależność ta, zaobserwowana w wielu językach świata, nazywana jest symbolizmem dźwiękowym ${ }^{18}$.

O kulturowo uwarunkowanym charakterze doznań synestezyjnych wspomina też kompozytor György Ligeti. Doświadczane przez niego wrażenia miały znamiona synestezji neurologicznej, choć klinicznie nie zostały potwierdzone. Uwagę zwraca jego komentarz towarzyszący opisowi międzyzmysłowych skojarzeń łączących litery i cyfry z kolorami:

At some point these associations must have got fixed, perhaps I saw the green number 5 on a stamp or on a shop sign. But there must be some collective associations too. For most people the sound of trumpet is probably yellow although I find it red because of its shrillness... ${ }^{19}$

Lawrence Marks dowodzi, iż asocjacje między dźwiękiem i kolorem są powszechne i regularne również wśród niesynestetyków - nazywa je uniwersalnymi doświadczeniami synestezyjny-

17 Por.: M. Senderecka, Synestezja..., s. 275.

18 V. S. Ramachandran, E. M. Hubbard, Synaesthesia - A Window Into Perception, Thought and Language..., s. 20-21; patrz również: M. Senderecka, Synestezja..., s. 275.

19 György Ligeti in Conversation with Péter Várnai, Josef Häusler, Claude Samuel, and Himself, Eulenburg Books, London 1983, s. 58; podaję za: S. Shaw-Miller, Synaesthesia, [w:] T. Shephard, A. Leonard (eds), The Routledge Companion to Music and Visual Culture, Routledge, New York 2014, s. 15. 
$\mathrm{mi}^{20}$. Podstawę synestezji, wywoływanej zarówno przez muzykę, jak i dźwięki mowy (np. samogłoski), upatrywał w regułach kojarzenia bodźców wizualnych i słuchowych, sprowadzanych do relacji między wizualną intensywnością i rozmiarem a słuchowym tonem i głośnością. Jak wykazały obserwacje, wysokie tony dźwięków mogą wywoływać wrażenia wizualne małych rozmiarów, natomiast niskie tony - wrażenia większych rozmiarów ${ }^{21}$; jasne, jaskrawe kolory kojarzone są z wysokimi tonami dźwięków, podczas gdy ciemne kolory w powszechnym odczuciu korespondują z niskimi ${ }^{22}$. Projekt Radera i Tellegena potwierdził spostrzeżenia Marksa i wykazał, że projektowanie wrażeń dźwiękowych na barwy przebiega zgodnie $\mathrm{z}$ uniwersalnymi regułami dostępnymi nie tylko synestetykom ${ }^{23}$.

\section{Synestezja silna i staba}

W konsekwencji przeprowadzonych badań Marks i Martino ${ }^{24}$ w artykule zatytułowanym Synesthesia: Strong and Weak zaproponowali wyróżnienie dwóch form synestezji: silnej i słabej. Silna synestezja wyraża percepcyjne cechy bodźców pochodzących z różnych modalności, natomiast podstawą słabej synestezji są międzyzmysłowe asocjacje. Obie formy podlegają tym samym podstawowym mechanizmom percepcyjnego kodowania w systemie nerwowym i mechanizmom międzymodalnego przetwarzania

20 L. E. Marks, On Colored-Hearing Synesthesia: Cross-Modal Translations of Sensory Dimensions, „Psychological Bulletin”, maj 1975, vol. 82, No 3, s. 303.

21 Ibidem, s. 312-313.

22 Por.: Ch. Rader, A. Tellegen, A Comparison of Synesthetes and Nonsynesthetes, [w:] E. Klinger (ed.), Imagery, t. II, Concepts, Results and Applications, Plenum Press, New York 1981, s. 154.

23 Ibidem.

24 G. Martino, L. E. Marks, Synesthesia: Strong and Weak, „Current Directions in Psychological Science", April 2001, vol. 10, No 2, s. 61-65. 
informacji. Różnice między silną i słabą synestezją autorzy artykułu przedstawili w postaci tabeli (por. tab. 5).

Podstawą synestezji silnej są relacje między psychofizycznymi jakościami zmysłowymi, takimi jak częstotliwość, intensywność i czas trwania dźwięku; rozmiar, kształt oraz spektrum fali świetlnej obiektu wzrokowego; chemiczna kompozycja smaku. Akustyczne cechy bodźca dźwiękowego, do których należą, na przykład, wysokość (częstotliwość) i głośność (intensywność), korespondują we wtórnym wrażeniu synestezyjnym z właściwościami wzrokowymi - kształtem, rozmiarem i kolorem, na niskim, sensorycznym poziomie systemu nerwowego, na zasadzie podobnej do tej, na podstawie której odbywa się kodowanie fizycznych cech informacji w różnych systemach zmysłowych.

W przypadku synestezji słabej pośrednictwo językowe, wpływy doświadczenia i kultury oraz efekty treningu (uczenia się) modyfikują skojarzenia międzyzmysłowe, rozszerzają spektrum potencjalnych połączeń między poszczególnymi wymiarami zmysłów. Asocjacje podlegają wtórnym procesom umysłowej integracji zmysłów na wysokim poziomie semantycznym ${ }^{25}$.

Tabela 5

\section{Cechy synestezji silnej i słabej}

\begin{tabular}{|l|l|l|}
\hline \multicolumn{1}{|c|}{ Cecha } & \multicolumn{1}{|c|}{ Synestezja silna } & \multicolumn{1}{c|}{ Synestezja słaba } \\
\hline 1 & \multicolumn{1}{|c|}{2} & \multicolumn{1}{c|}{3} \\
\hline $\begin{array}{l}\text { Powszechne } \\
\text { występowanie }\end{array}$ & $\begin{array}{l}\text { nie jest powszechna, jest } \\
\text { wrodzona, o cechach } \\
\text { indywidualnych; częściej } \\
\text { występuje u kobiet niż } \\
\text { u mężczyzn* }\end{array}$ & powszechna \\
\hline $\begin{array}{l}\text { Sposób łączenia } \\
\text { doznań }\end{array}$ & $\begin{array}{l}\text { jeden bodziec jest postrze- } \\
\text { gany za pośrednictwem } \\
\text { zmysłów, drugi natomiast } \\
\text { jest doświadczany jako } \\
\text { wyobrażenie }\end{array}$ & $\begin{array}{l}\text { obydwa bodźce są postrze- } \\
\text { gane zmysłami }\end{array}$ \\
\hline
\end{tabular}

25 Patrz: A. Rogowska, Czy synestetycy sq wśród nas?..., s. 39-40. 


\begin{tabular}{|l|l|l|}
\hline \multicolumn{1}{|c|}{1} & \multicolumn{1}{|c|}{2} & \multicolumn{1}{c|}{3} \\
\hline $\begin{array}{l}\text { Organizacja współod- } \\
\text { czucia }\end{array}$ & $\begin{array}{l}\text { idiosynkratyczna i systema- } \\
\text { tyczna }\end{array}$ & systematyczna \\
\hline $\begin{array}{l}\text { Sposób definiowania } \\
\text { współodczuć }\end{array}$ & $\begin{array}{l}\text { arbitralnie, niezależnie } \\
\text { od kontekstu }\end{array}$ & poprzez kontekst \\
\hline Rola uczenia się & $\begin{array}{l}\text { niektóre mogą być niewy- } \\
\text { uczone** }\end{array}$ & $\begin{array}{l}\text { niektóre są wyuczone, inne } \\
\text { - niewyuczone. }\end{array}$ \\
\hline $\begin{array}{l}\text { Asocjacje seman- } \\
\text { tyczne }\end{array}$ & dosłowne & metaforyczne \\
\hline Pamięć & $\begin{array}{l}\text { latwo identyfikowane } \\
\text { i przypominane }\end{array}$ & $\begin{array}{l}\text { łatwo identyfikowane } \\
\text { i przypominane }\end{array}$ \\
\hline $\begin{array}{l}\text { Przetwarzanie infor- } \\
\text { macji }\end{array}$ & $\begin{array}{l}\text { jednokierunkowe na } \\
\text { niskim, percepcyjnym } \\
\text { poziomie }\end{array}$ & $\begin{array}{l}\text { dwukierunkowe na } \\
\text { wysokim, semantycznym } \\
\text { poziomie }\end{array}$ \\
\hline
\end{tabular}

* Badania prowadzone w Anglii nad częstotliwością występowania synestezji wykazały pojawianie się tego fenomenu w jednym na 2000 przypadków, z przewagą kobiet $w$ stosunku do mężczyzn 6,3:1. Z kolei badania nad rodzinami synestetyków wykazały, że prawdopodobieństwo wystąpienia synestezji u córki synestetyka wynosi $72 \%$, u syna zaś - $25 \%$. Możliwość wystąpienia synestezji u sióstr sięga $60 \%$, natomiast u braci - 16,6\%. Najprawdopodobniej dziedziczność synestezji jest związana z żeńskim chromosomem X - patrz: A. Rogowska, $C z y$ synestetycy sa wśród nas?..., s. 37.

** Choć synestezja określana jest dziś jako zjawisko uwarunkowane genetycznie i fizjologicznie, nie bez znaczenia jest też wpływ czynników kulturowych. Do pewnego stopnia jest ona „wyuczana” - osoby obdarzone tym darem uczą się być synestetykami. Większość, jeśli nie wszystkie, skojarzeń synestezyjnych powstaje niezależnie od życiowego doświadczenia osoby odczuwającej. Zdarzają się jednak rzadkie przypadki, gdy wśród tych sekwencji (np. w alfabecie) pojawia się kilka, które można odnieść do dziecięcych skojarzeń - por.: S. A. Day, Some demographic and socio-cultural aspects of synesthesia, [w:] L. Robertson, N. Sagiv (eds), Synesthesia: Perspectives from Cognitive Neuroscience, OUP, Oxford 2005, s. 17.

Źródło: G. Martino, L. E. Marks, Synesthesia: Strong and Weak, „Current Directions in Psychological Science”, April 2001, vol. 10, No 2, s. 63-64. 


\section{Ogólne tendencje synestezyjne}

Zastanawiać i prowokować do dalszych badań może zbieżność, którą dostrzeżemy w zestawieniu opracowanym przez Freda Collopy'ego:

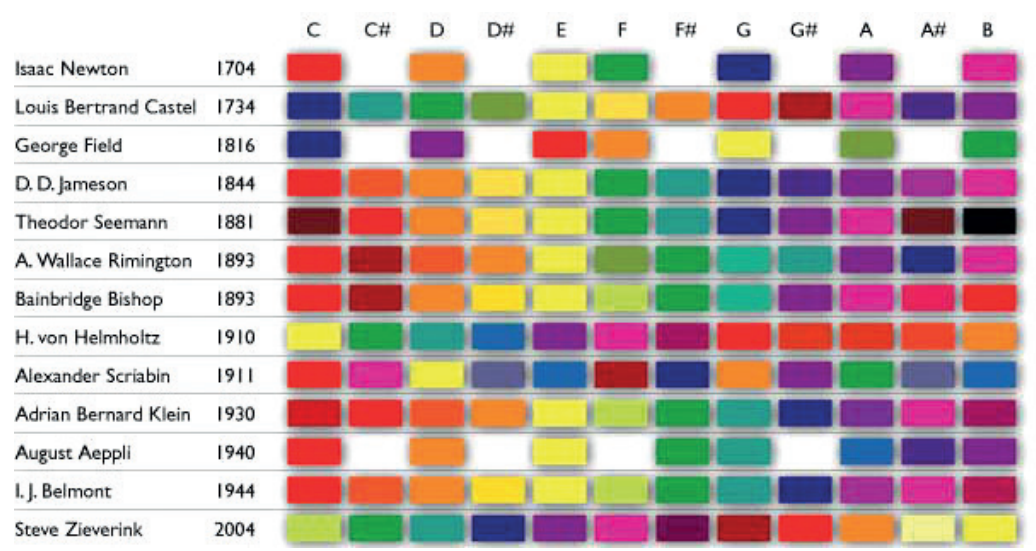

Ilustracja 9. Relacje między kolorem i dźwiękiem u niesynestetyków Opracowanie Freda Collopy'ego

Źródło: F. Collopy, Three Centuries of Color Scales, https://modernpost.wordpress.com/2009/06/17/musical-musings-colour-music/ [dostęp: 25.01.2015]

W większości przedstawionych tu przypadków mamy do czynienia z propozycjami przypisania kolorów do dźwięków pochodzącymi od niesynestetyków, choć fakt ten nie determinuje korelacji między barwą i dźwiękiem. Synestezja nie ujawnia przecież uniwersalnych tendencji asocjacyjnych. Zastanawia zatem dostrzegalna zgodność między odczuciami i/lub ustaleniami osób żyjących w różnych miejscach i w różnym czasie. Dlaczego tonacja C-dur kojarzy się głównie z barwą czerwoną, E-dur z żółtą, D-dur z pomarańczową, a Fis-dur z zieloną? Zjawisko to można oczywiście wytłumaczyć wpływem wcześniejszych badaczy i ich prac na ko- 
lejne pokolenia. Wielu z wymienionych wyżej uczonych i twórców było zainspirowanych np. Optyka Newtona. Nie w każdej jednak sytuacji jest on decydujący i determinujący kierunek pojawiających się asocjacji. Czy można tu zatem mówić o uniwersalnych doświadczeniach synestezyjnych? Chyba nie, skoro nawet w tej stosunkowo niewielkiej grupie uczonych połączonych wspólnymi poszukiwaniami korelacji między doznaniami zmysłowymi obok wielu podobieństw pojawiają się znaczące różnice. Jak to już niejednokrotnie podkreślaliśmy, nie ma dwojga ludzi, którzy kojarzą w ten sam sposób. Nie istnieją też żadne zasady czy reguły łączenia kolorów z dźwiękami i na odwrót. Hipoteza translacji, zakładająca analogię między drganiami fal świetlnych i dźwiękowych, została obalona. Podobnie hipotezy mówiące o pośrednictwie emocjonalnym, symbolicznym czy mistycznym między dźwiękiem i kolorem ${ }^{26}$. Na obecnym etapie badań trudno więc o jednoznaczną i ostateczną odpowiedź na tak postawione pytanie.

Kojarzenie dźwięków z kolorami nie jest jedyną tendencją obecną w postrzeganiu świata przez ludzi bez względu na ich zdolności synestezyjne. Eksperyment przeprowadzony przez zespół złożony z pracowników Wydziału Psychologii Uniwersytetu w Edynburgu i Londynie wykazał, że wśród niesynestetyków można zaobserwować pewne regularności w doborze kolorów do znaków graficznych cyfr i liter alfabetu ${ }^{27}$. Na przykład: znacząca grupa uczestników określiła $\mathrm{w}$ jako białe, $\mathrm{b}$ jako niebieskie, y jako żółte, $\mathrm{r}$ jako czerwone. Zjawisko to do pewnego stopnia można jednak wyjaśnić posiadanymi umiejętnościami lingwistycznymi. Nazwy podanych kolorów rozpoczynają się bowiem literą, kolor której należało określić: $\mathrm{w}$ - white, $\mathrm{b}$ - blue, $\mathrm{r}$ - red, y - yellow. Spostrzeżenie to potwierdza fakt, że w przypadku, gdy w językach angielskim

\footnotetext{
26 Ibidem, s. 41.

27 J. Simner, J. Ward, M. Lanz, A. Jansari, K. Noonan, L. Glover, D. A. Oakley, Non-random associations of graphemes to colours in synaesthetic and non-synaesthetic population, „Cognitive Neuropsychology” [Psychology Press Ltd.] 2005, 22 (8), wersja on-line: http://www.daysyn.com/Simneretal2005.pdf [dostęp: 5.02.2015], s. 1069-1085.
} 
i niemieckim (część uczestników eksperymentu pochodziła z Niemiec) wystąpiła rozbieżność ortograficzna w nazwach kolorów, barwę litery nadal dopasowywano do litery inicjującej wyraz, tzn.: kolor fioletowy został przyporządkowany do $\mathrm{p}$ w grupie angielskojęzycznej (purple) i do $1 \mathrm{w}$ grupie niemieckojęzycznej (lila) ${ }^{28}$.

Zasadnicze znaczenie dla naszych rozważań ma też stwierdzenie Bleuera i Lehmana:

Fotyzmy występują u wszystkich ludzi, u jednych częściej, u innych rzadziej, gdyż inaczej nie dałoby się w poezji za ich pomocą malować i wrażenia przenosić z jednego organu zmysłu na drugi w sposób zrozumiały ${ }^{29}$.

Podobną myśl wyraża Albert Wellek, który wysunął hipotezę „prasynestezji” rozumianej jako ogólnoludzkie, możliwe do potwierdzenia w sferach językowych najrozmaitszych narodów, odpowiedniki między jakościami różnych obrazów zmysłowych. Przykładem może być określanie dźwięków jako wysokie i niskie, wąskie i szerokie, małe i duże, lekkie i ciężkie, jasne i ciemne, chłodne i ciepłe ${ }^{30}$.

\section{Synestezyjne metafory Nabokova}

\section{Motyw tęczy}

Twórczość Vladimira Nabokova nasycona jest skojarzeniami łączącymi doznania zmysłowe, których nie można określić jako sy-

28 Więcej o roli czynnika lingwistycznego (fonologicznego i ortograficznego) w synestezyjnych doznaniach smaku patrz: J. Ward, J. Simner, Lexical-gustatory synaesthesia: linguistic and conceptual factors, „Cognition” 2003, vol. 89, s. 237 261, http://www.daysyn.com/WardSimner2003.pdf [dostęp: 6.02.2015].

29 E. Bleuer, K. Lehman, Zwangsmassige Lichtempfindungen durch Schall und verwandte Ersheinungen auf dem Gebeite der andern Sinnesempfindungen, Fues's Verlag, Leipzig 1881, podaję za: A. Rogowska, Związki synestezji z muzyka..., s. 89.

30 Podaję za: A. Rogowska, Czy synestetycy są wśród nas?..., s. 42. 
nestezyjne w znaczeniu zjawiska o podłożu neuronalnym. Motyw chromatycznej litery należy do tych asocjacji, które bardzo często pojawiają się w stylistycznej warstwie tekstów. Przybiera on często postać lejących się strumieniem neonów elektrycznych, podobnych do drogocennych kamieni szlachetnych, które w pewnym stopniu biorą swój początek z dziecięcych wspomnień pisarza:

Как я любил кольца на материнской руке, ее браслеты! Бывало, в петербургском доме, в отдаленнейшей из ее комнат, она вынимала из тайника в стене целую груду драгоценностей, чтобы позанять меня перед сном. Я был тогда очень мал, и эти струящиеся диадемы и ожерелья не уступали для меня в загадочном очаровании табельным иллюминациям, когда в ватной тишине зимней ночи гигантские монограммы и венцы, составленные из цветных электрических лампочек - сапфировых, изумрудных, рубиновых, - глухо горели над отороченными снегом карнизами домов ${ }^{31}$.

Bohater pierwszej powieści pt. Maszeńka przypadkiem dowiaduje się, że jego pierwsza miłość niebawem przyjedzie do Berlina do swojego męża. Oszołomiony tą informacją, Ganin spaceruje ulicami miasta i w nocnych ciemnościach dostrzega elektryczny szyld reklamowy, który przybiera kształt jego myśli:

Ярче, веселее звезд были огненные буквы, которые высыпали одна за другой над черной крышей, семенили гуськом и разом и пропадали во тьме. «Неужели... это... возможно...»- огненным осторожным шепотом проступали буквы, и ночь одним бархатным ударом смахивала их. «Неужели... это...» - опять начинали они, крадясь по небу. [...] Впрочем, черт его знает, что на самом деле играло там, в темноте, над домами, световая ли реклама или человеческая мысль, знак, зов, вопрос, брошенный в небо и получающий вдруг самоцветный, восхитительный ответ ${ }^{32}$.

31 В. В. Набоков, Другие берега, [w:] Владимир Набоков. Собрание сочинений в четырех томах, под ред. В. В. Ерофеева, т. 4, Издательство «Правда», Москва 1990, s. 147.

32 В. В. Набоков, Машенька, [w:] Владимир Набоков. Собрание сочинений в четырех томах, под ред. В. В. Ерофеева, т. 1, Издательство «Правда», Москва 1990, s. 53. 
W Zaproszeniu na egzekucję z kolei

горел разноцветным светом добрый миллион лампочек, искусно рассаженных, в траве, на ветках, на скалах, и в общем размещенных таким образом, чтобы составить по всему ночному ландшафту растянутый грандиозный вензель из П. и Ц33.

Jednakże motyw spektrum barw i bliski mu motyw tęczy znajdują swoją metaforyczną realizację również na gruncie Nabokovowskiej chromestezji. Jak pamiętamy z poprzedniego rozdziału, w obydwu wariantach autobiografii pisarz szczegółowo prezentuje wrażenia barw doznawane pod wpływem słyszanych dźwięków odpowiadających literom alfabetu. Na zakończenie każdego wykazu podał, jak wyglądałaby tęcza zapisana za pomocą liter prezentujących określone barwy: ВЁЕПСК3 zapisana literami alfabetu rosyjskim oraz KZSPYGV - literami alfabetu łacińskiego. Donald Johnson dostrzegł w tych konfiguracjach pewien zabieg autorski naśladujący naturę, który uwidacznia się po przeanalizowaniu obydwu akronimów, biorąc pod uwagę podstawowe kolory, do których odnoszą się odcienie opisane przez Nabokova ${ }^{34}$. W wersji rosyjskiej akronim tworzą: B - czerwone, $\ddot{E}$ - pomarańczowe, E - żółte, $\Pi$-zielone, $\mathrm{C}$ - niebieskie, $\mathrm{K}$ - granatowe, 3 - fioletowe. Angielski akronim przedstawia barwy w odwrotnej kolejności niż jego rosyjski odpowiednik: $\mathrm{K}$ - fioletowe, $\mathrm{Z}$ - granatowe, $\mathrm{S}$ - niebieskie, $\mathrm{P}$ - zielone, Y - żółte, G - pomarańczowe, V - czerwone. Relacje między słowami-tęczami Johnson zestawia w sposób, który pozwala dostrzec zasygnalizowaną różnicę (tab. 6) ${ }^{35}$.

Angielski i rosyjski akronimy prezentują kolory w odwrotnych porządkach względem siebie: rosyjski CPŻZNGF, angielski FGNZŻPC. W konsekwencji okazuje się, że są one wzajemnie swoimi

33 В. В. Набоков, Приглашение на казнь, [w:] Владимир Набоков. Собрание сочинений..., т. 4, s. 110.

34 Д. Джонсон, Миры и антимиры Владимира Набокова, пер. Т. Стрелковой, Издательство Симпозиум, Санкт-Петербург 2011, s. 7.

35 Tabela przygotowana na podstawie schematu, [w:] Д. Джонсон, Mupь и антимиры Владимира Набокова..,, s. 7. 
lustrzanymi odbiciami. Źródeł celowości takiego zabiegu Johnson upatruje w dążeniu autora Daru do naśladowania przyrody. Dostrzega przy tym wpływ wyników jego obserwacji prowadzonych w zakresie naukowych prac badawczych. W przyrodzie oprócz tęczy pierwotnej pojawia się też wtórna, mniej jasna i znacznie szersza, na zewnątrz tęczy właściwej. Druga tęcza powstaje w rezultacie dwukrotnego odbicia światła wewnątrz kropli wody i tworzy łuk o kącie widzenia $50-53^{\circ}$. Co istotne, barwy tęczy wtórnej ułożone są odwrotnie; kolor czerwony znajduje się na dole, a fioletowy - na górze.

Tabela 6

Akronimy-tęcze Nabokova

\begin{tabular}{|c|c|c|c|c|c|c|c|c|c|c|c|c|}
\hline \multicolumn{7}{|c|}{$\begin{array}{c}\text { Rosyjski } \\
\text { В Ё Е П С К } 3\end{array}$} & \multicolumn{6}{|c|}{$\begin{array}{c}\text { Angielski } \\
\text { K Z S P Y G V }\end{array}$} \\
\hline C & $\mathbf{P}$ & $\dot{\mathbf{Z}}$ & $\mathbf{Z}$ & $\mathbf{N}$ & G & $\mathbf{F}$ & $\mathbf{F}$ & G & $\mathbf{N}$ & $\mathbf{Z}$ & $\dot{\mathbf{Z}}$ & $\mathbf{P}$ \\
\hline $\mathrm{z}$ & o & ó & $\mathrm{i}$ & $\mathrm{i}$ & $r$ & $\mathrm{i}$ & $\mathrm{i}$ & $\mathrm{r}$ & $\mathrm{i}$ & $\mathrm{i}$ & ó & 0 \\
\hline $\mathrm{e}$ & $\mathrm{m}$ & 1 & $\mathrm{e}$ & $\mathrm{e}$ & $\mathrm{a}$ & 0 & 0 & $\mathrm{a}$ & $\mathrm{e}$ & $\mathrm{e}$ & 1 & $\mathrm{~m}$ \\
\hline $\mathrm{r}$ & $\mathrm{a}$ & $\mathrm{t}$ & 1 & $\mathrm{~b}$ & $\mathrm{n}$ & 1 & 1 & $\mathrm{n}$ & b & 1 & $\mathrm{t}$ & $\mathrm{a}$ \\
\hline $\mathrm{w}$ & $\mathrm{r}$ & $\mathrm{y}$ & 0 & $\mathrm{i}$ & $\mathrm{a}$ & $\mathrm{e}$ & $\mathrm{e}$ & $\mathrm{a}$ & $\mathrm{i}$ & 0 & $\mathrm{y}$ & $\mathrm{r}$ \\
\hline 0 & $\mathrm{a}$ & & $\mathrm{n}$ & $\mathrm{e}$ & $\mathrm{t}$ & $\mathrm{t}$ & $\mathrm{t}$ & $\mathrm{t}$ & $\mathrm{e}$ & $\mathrm{n}$ & & $\mathrm{a}$ \\
\hline $\mathrm{n}$ & ń & & $\mathrm{y}$ & $\mathrm{s}$ & $\mathrm{o}$ & 0 & 0 & 0 & $\mathrm{~s}$ & $\mathrm{y}$ & & ń \\
\hline $\mathrm{y}$ & $\mathrm{c}$ & & & $\mathrm{k}$ & $\mathrm{w}$ & $\mathrm{W}$ & $\mathrm{w}$ & $\mathrm{w}$ & $\mathrm{k}$ & & & $\mathrm{c}$ \\
\hline & $z$ & & & $\mathrm{i}$ & $\mathrm{y}$ & $\mathrm{y}$ & $\mathrm{y}$ & $\mathrm{y}$ & $\mathrm{i}$ & & & $\mathrm{z}$ \\
\hline & o & & & & & & & & & & & o \\
\hline & $\mathrm{w}$ & & & & & & & & & & & w \\
\hline & $\mathrm{y}$ & & & & & & & & & & & $\mathrm{y}$ \\
\hline
\end{tabular}

Źródło: opracowanie na podstawie schematu D. Johnsona. Д. Джонсон, Миры и антимиры Владимира Набокова, пер. Т. Стрелковой, Издательство Симпозиум, Санкт-Петербург 2011, s. 7, on-line: http://royallib.com/book/ dgonson_donald/miri_i_antimiri_vladimira_nabokova.html [dostęp: 3.01.2015].

Akronim dla rosyjskiej tęczy Nabokova odpowiada zatem tęczy właściwej, natomiast akronim angielski - tęczy wtórnej, szerszej, lecz mniej wyraźnej w porównaniu z pierwszą. Co ciekawe, pisarz, znany jako mistrz kamuflażu i technik nieustannego wprowadzania 
czytelnika w błąd, w angielskiej autobiografii określa swoją tęczę utworzoną z łacińskich liter jako pierwotną ${ }^{36}$. O odcieniach rosyjskich liter pisze natomiast jako o przytłumionych w porównaniu z angielskimi ${ }^{37}$, co sugerować może „nadrzędną” pozycję alfabetu angielskiego wobec rosyjskiego. Przeczy temu jednak układ i wzajemne lustrzane relacje między barwami obu tęcz, co ilustruje zaproponowany przez Johnsona schemat w jego rosyjskojęzycznej wersji:

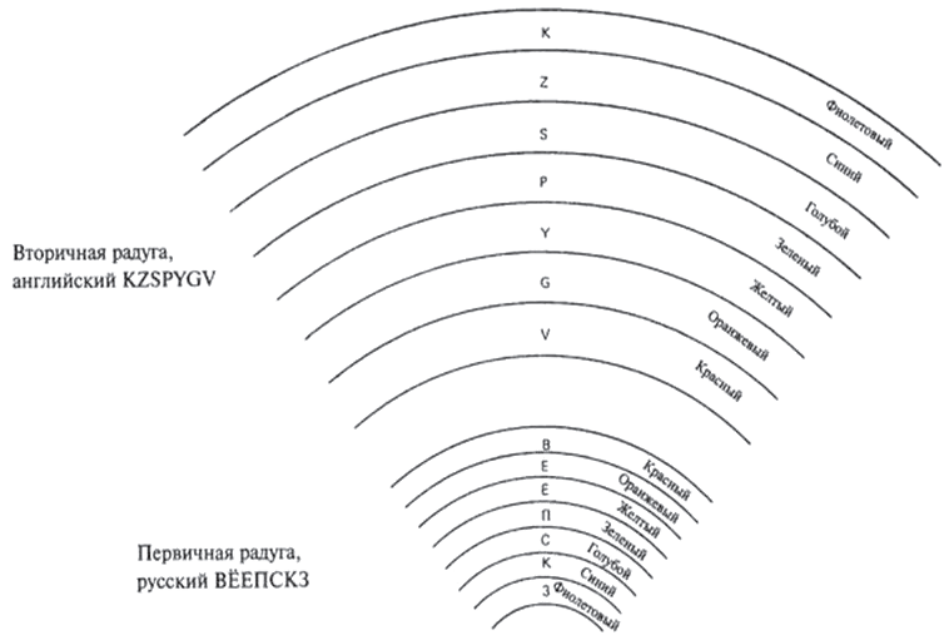

Ilustracja 10. Akronimiczne tęcze Nabokova

Źródło: opracowanie na podstawie schematu D. Johnsona. Д. Джонсон, Mиры и антимиры Владимира Набокова, пер. Т. Стрелковой, Издательство Симпозиум, Санкт-Петербург 2011, s. 7, on-line: http://royallib.com/book/dgonson_donald/miri_i_antimiri_vladimira_nabokova.html [dostęp: 3.01.2015]

${ }^{36}$ V. Nabokov, Speak, Memory: An Autobiography Revisited, Vintage International, Knopf Doubleday Publishing Group, New York, 2011 [wersja on-line:] http://www.rulit.me/books/speak-memory-an-autobiography-revisitedread-336809-16.html [dostęp: 13.02.2015], s. 6.

37 В. В. Набоков, Другие берега..., s. 146. 
W ten metaforyczny sposób, zdaniem Johnsona, Nabokov przedstawił relacje między swoją rosyjską i angielską twórczością. Podstawą pierwszej, właściwej, wyraźnej i barwnej rosyjskojęzycznej twórczości był rodzimy język pisarza z jego leksykalnym bogactwem, co niejednokrotnie podkreślał w wywiadach i o czym była mowa już wcześniej. Język angielski traktował jako drugorzędne, mniej posłuszne i nie tak „barwne” narzędzie pracy.

W metaforze podwójnej tęczy można się jednak dopatrzeć również odzwierciedlenia indywidualnych cech Nabokovowskiej chromestezji. $Z$ opisu własnych doznań pisarza, pozostawionego $w$ jego autobiografiach, wynika, że brzmienie przynajmniej niektórych liter rosyjskiego alfabetu odbierał w sposób bardziej wyraźny i jaskrawy niż łacińskiego. Odcień wilgotnego błękitu rosyjskiego „C” wydaje się silniejszy i bardziej intensywny niż perłowy lazur łacińskiego „S”. Podobnie złocisty odcień żółtej barwy rosyjskiego „Y” w porównaniu z oliwkowym połyskiem mosiądzowego łacińskiego „U” odczuwany był przez pisarza prawdopodobnie jako bardziej jaskrawy. To samo można powiedzieć o wiśniowo-ceglastym odcieniu „Б”, który Nabokov określił jako gęstszy od sjeny palonej łacińskiego „B”. Nie będzie zatem nadużyciem stwierdzenie, że oprócz odniesień do twórczości literackiej pisarza w całości, z uwzględnieniem jej etapów rosyjsko- i angielskojęzycznego, metafora tęczy obrazuje sposób barwnego doświadczania liter obydwu alfabetów i ich wzajemnych relacji pod względem intensywności wrażeń.

Potwierdzeniem dla interpretacji chromestezyjnej podwójnej tęczy Nabokova może być pierwsze rosyjskie wydanie Lolity w przekładzie autorskim (1967): tytuł na okładce powieści został przedstawiony w kolorach tęczy podwójnie, jak w lustrzanym odbiciu, przy czym barwy dolnego, odwróconego wyrazu przedstawione są w odwrotnej kolejności w stosunku do górnego, pierwotnego.

Johnson dostrzega w tym podwójny zabieg pisarza, który miał jeszcze wówczas decydujący głos w sprawach edytorskich: po pierwsze, owe odwrócone alfabetyczne tęcze imitują proces autoprzekładu powieści z języka angielskiego na rosyjski; po drugie 
zaś, podobnie jak w przypadku prezentacji doznań chromestezyjnych w autobiografiach, symbolizują dwujęzyczną ewolucję twórczą Nabokova ${ }^{38}$.

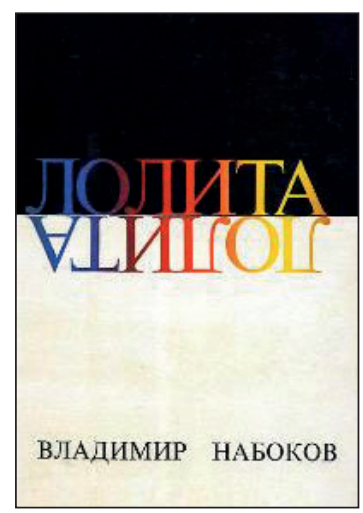

\section{Ilustracja 11. Okładka pierwszego rosyjskiego wydania Lolity} w przekładzie autorskim

Źródło: http://ru-nabokov.livejournal.com/254027.html [dostęp: 5.06.2015]

Motyw bliźniaczej tęczy, jakkolwiek oparty na chromestezyjnych doświadczeniach pisarza, sam w sobie nie jest przykładem synestezji psychologicznej, lecz literackiej. Wykorzystanie synestezji jako podstawy metafory literackiej jeszcze nie oznacza, że jest ona siłą napędową w procesie twórczym. W omawianym tu przypadku wrodzone doznania międzysensoryczne pisarza okazały się wygodnym i trafnym środkiem do utworzenia metafory symbolizującej proces twórczy. Ku takiej opinii skłania się również Johnson ${ }^{39}$, który rozstrzygnięcie problemu relacji między synestezyjnym darem Nabokova i jego twórczością widzi nie w jednej ze stron, lecz gdzieś pośrodku - w pamięci, która zawiera w sobie synestezyjne obrazy z przeszłości i stanowi podstawę do wszelkich działań twórczych.

38 Д. Джонсон, Миры и антимиры Владимира Набокова.., s. 7.

39 Ibidem, s. 7. 
Warto jeszcze na koniec zaznaczyć, że motyw tęczy pojawia się w tekstach Nabokova jako epitet, określenie szczególnego rodzaju efektów kolorystycznych czy element typowej metafory literackiej. Van w Adzie mówi o tęczowej mgle anielskich duchów po drugiej stronie kosmicznej drogi ${ }^{40}$. Cyncynat wędruje z Marfińką po Ogrodach Tamary z ich strumieniami, spadającymi w dół trzema kaskadami, nad którymi tworzyły się tęcze ${ }^{41}$. Powiew zaś wolności rozbudził w nim marzenia, jakby przed oczami tańczyło mu tysiąc tęczowych igiełek wokół oślepiającego odbicia słońca na niklowanej kuli ${ }^{42}$. W Lolicie interesujące odniesienie do tęczy związane jest $\mathrm{z}$ grupą siedmiu dziewcząt biorących udział $\mathrm{w}$ sztuce teatralnej. 'Girlanda małych gracji' przedstawiała żywą tęczę na wzór dzieci-kwiatów w tekście Jamesa Joyce'a ${ }^{43}$.

\section{Synestezyjne postrzeganie czasu i przestrzeni}

W czwartej części Ady znajdziemy obszerne opowiadanie Vana Veena w formie traktatu o Fakturze Czasie, Przestrzeni i ich wzajemnych relacjach. W przedstawieniu tych pojęć pomocna okazała się synestezja, do której autor, jak sam napisał, ,jest ogromnie skłonny"44. Van ubarwia swoje rozważania znaczną liczbą metafor i porównań bazujących na doznaniach zmysłowych, co wynika też z natury zjawisk, w których skumulowane zostały wrażenia sensoryczne. W konsekwencji kategorie czasu i przestrzeni przedstawiane są za pomocą danych zmysłowych. Możliwości Przestrzeni obejmują szybkość, z jej gładkością świstu szabli, chwałę opanowania pędu i radosny okrzyk wirażu ${ }^{45}$. Czas natomiast daje zmysłową

40 V. Nabokov, Ada or Ardor: A Family Chronicle, McGraw-Hill Book Company, New York-Toronto 1969, s. 21.

41 В. В. Набоков, Приглашение на казнь.., s. 15.

42 Ibidem, s. 41.

43 V. Nabokov, Lolita, Penguin Books, London 1995, s. 221.

44 V. Nabokov, Ada albo Żar. Kronika rodzinna, przeł. L. Engelking, Warszawskie Wydawnictwo Literackie MUZA SA, Warszawa 2009, s. 657.

45 Patrz: ibidem, s. 641. 
przyjemność smakowania trwania, jego substancji i rozpiętości, niewyczuwalności jego szarawej gazy w chłodzie ciągłości:

One can be a lover of Space and its possibilities: Take, for example, speed, the smoothness and sword-swish of speed; the aquiline glory of ruling velocity; the joy cry of the curve; and one can be an amateur of Time, an epicure of duration. I delight sensually in Time, in its stuff and spread, in the fall of its folds, in the very impalpability of its grayish gauze, in the coolness of continuum. I wish to do something about it; to indulge in a simulacrum of possession. I am aware that all who have tried to reach the charmed castle have got lost in obscurity or have bogged down in Space. I am also aware that Time is a fluid medium for the culture of metaphors ${ }^{46}$.

Zarówno Czas, jak i Przestrzeń są odbierane przez organy zmysłów. Przestrzeń można oglądać, Czasu zaś - słuchać. O akustyce czasu mówi też Humbert w Lolicie, gdy wspomina namiętne chwile spędzone ze swoją nimfetką: „Lo! Lola! Lolita! I hear myself crying from a doorway into the Sun, with the acoustics of time, domed time, endowing my call and its tell-tale hoarseness with such a wealth of anxiety, passion and pain..." ${ }^{47}$ Czas jest więc rytmem wyznaczanym przez wydarzenia; jest szarą luką między czarnymi uderzeniami ${ }^{48}$. Czas jest słyszalny tak, jak krew krążąca w mózgu:

If my eye tells me something about Space, my ear tells me something about Time. But while Space can be contemplated, naively, perhaps, yet directly, I can listen to Time only between stresses, for a brief concave moment warily and worriedly, with the growing realization that I am listening not to Time itself but to the blood current coursing through my brain, and thence through the veins of the neck heartward, back to the seat of private throes which have no relation to Time $^{49}$.

Niewyraźne interwały między mrocznymi uderzeniami dają uczucie faktury Czasu. To samo odnosi się do wrażeń związanych

\footnotetext{
46 V. Nabokov, Ada or Ardor: A Family Chronicle..., s. 537.

47 V. Nabokov, Lolita..., s. 236.

48 V. Nabokov, Ada or Ardor: A Family Chronicle..., s. 538.

49 Ibidem, s. 538.
} 
z postrzeganiem luk niepamiętanego czasu między wyraźnymi wydarzeniami. Dla ilustracji Van podaje przykład kolorystycznie zapamiętanych trzech wykładów pożegnalnych i dzielących je dni:

I happen to remember in terms of color (grayish blue, purple, reddish gray) my three farewell lectures - public lectures - on Mr. Bergson's Time at a great university a few months ago. I recall less clearly, and indeed am able to suppress in my mind completely, the six-day intervals between blue and purple and between purple and gray. But I visualize with perfect clarity the circumstances attending the actual lectures. [...] The two intervals of five days each are seen by me as twin dimples, each brimming with a kind of smooth, grayish mist, and a faint suggestion of shed confetti (which, maybe, might leap into color if I allowed some casual memory to form in between the diagnostic limits) $)^{50}$.

Czas związany jest zatem ze słuchem i barwnym postrzeganiem zapamiętanych przeszłych wydarzeń, natomiast Przestrzeń - ze wzrokiem, dotykiem i wysiłkiem mięśniowym:

Space is related to our senses of sight, touch, and muscular effort; Time is vaguely connected with hearing (still, a deaf man would perceive the „passage" of time incomparably better than a blind limbless man would the idea of ,passage”). „Space is a swarming in the eyes, and Time a singing in the ears", says John Shade, a modern poet, as quoted by an invented philosopher (,Martin Gardiner”) in The Ambidextrous Universe, page 165. Space flutters to the ground, but Time remains between thinker and thumb, when Monsieur Bergson uses his scissors ${ }^{51}$.

Czas jest perceptywny i dotykalny. Może mieć swoją formę i kształt. Zwykle jest postrzegany jako strumień, lecz nie ma nic wspólnego z wyobrażeniem górskiego strumienia czy rzeki:

We regard Time as a kind of stream, having little to do with an actual mountain torrent showing white against a black cliff or a dull-colored great river

50 Ibidem, s. 548-549.

51 V. Nabokov, Ada or Ardor: A Family Chronicle..., s. 542. 
in a windy valley, but running invariably through our chronographical landscapes ${ }^{52}$.

W swojej naturze Czas składa się z widmowych faz. Przeszłość to cienie i kształty, które nie są jeszcze wyraźnie oddzielone od Teraźniejszości i prześwitują przez miękkie, długie, larwalne „teraz”:

Has there ever been a „primitive" form of Time in which, say, the Past was not yet clearly differentiated from the Present, so that past shadows and shapes showed through the still soft, long, larval „now”? [...] Pure Time. Perceptual Time, Tangible Time, Time free of content, context, and running commentary - this is $m y$ time and theme ${ }^{53}$.

Przeszłość jest nagromadzeniem wrażeń zmysłowych. Wskazane przez Vana analogie przestrzenne pozwalają przedstawić „,bieg czasu” (wytwór ludzkiego umysłu) jako kształty i cienie, limby i modrzewie widziane w lusterku wstecznym:

I shall now proceed to consider the Past as an accumulation of sense, not as the dissolution of Time implied by immemorial metaphors picturing transition. The „passage of time” is merely a figment of the mind with no objective counterpart, but with easy spatial analogies. It is seen only in rear view, shapes and shades, arollas and larches silently tumbling away: the perpetual disaster of receding time, èboulements, landslides, mountain roads where rocks are always falling and men always working ${ }^{54}$.

Przeszłość jest więc również trwałym nagromadzeniem obrazów, dzięki czemu można jej doświadczać zmysłami - doznawać jej smaku, słuchać jej:

The Past, then, is a constant accumulation of images. It can be easily contemplated and listened to, tested and tasted at random, so that it ceases to mean the orderly alternation of linked events that it does in the large theoretical sense ${ }^{55}$.

52 Ibidem, s. 540.

53 Ibidem, s. 539.

54 Ibidem, s. 544.

55 V. Nabokov, Ada or Ardor: A Family Chronicle..., s. 545. 
Czas może mieć swoją pojemność i kolor. Przypomnijmy, że bohater Daru wspomina o porannej pojemności czasu: „Стало как-то неуютно. От утренней емкости времени не осталось ничего" "56. W Rozpaczy natomiast czas przedstawiony jest jako mętno-biaława masa:

Ведь я отправился в путь утром, а свидание мое с Феликсом было назначено на пять часов пополудни; дома мне не сиделось, но куда сбыть мутно-белое время, отделявшее меня от встречи?57

Połączenie doznań znanych z Przeszłości z Teraźniejszością tworzy realność faktury Czasu, jak stało się to podczas telefonicznej rozmowy Vana z Adą po ich wieloletniej rozłące. Brzmienie głosu Ady w połączeniu z ‘teraźniejszym' widokiem ciemniejących gór po drugiej stronie jeziora, utworzyło najważniejszą część jego najgłębszej percepcji dotykalnego czasu:

That telephone voice, by resurrecting the past and linking it up with the present, with the darkening slate-blue mountains beyond the lake, with the spangles of the sun wake dancing through the poplar, formed the centerpiece in his deepest perception of tangible time, the glittering "now" that was the only reality of Time's textures ${ }^{58}$.

Tak jak Czas nie jest strumieniem, tak też Przestrzenią nie może być, zdaniem Vana, taśma z podziałką. Podobnie drogi nie wyobraża w jego umyśle licznik samochodowy, lecz czarne lustro deszczu pod obracającymi się kołami, lepki szelest, zapach wilgotnej lipcowej nocy w Alpach, dotykowe wrażenie gładkiej podpory:

[...] no one shall make me believe that the movement of matter (say, a pointer) across a carved-out area of Space (say, a dial) is by nature identical

${ }^{56}$ В. В. Набоков, Дар, przeł. Е. Siemaszkiewicz, posł. L. Engelking, Warszawskie Wydawnictwo Literackie MUZA SA, Warszawa 2003, s. 141.

57 В. В. Набоков, Отчаяние, [w:] Владимир Набоков. Собрание сочинений в четырех томах, под ред. В. В. Ерофеева, т. 3, Издательство «Правда», Москва 1990, s. 429.

58 V. Nabokov, Ada or Ardor: A Family Chronicle..., s. 556. 
with the ,passing” of time. Movement of matter merely spans an extension of some other palpable matter, against which it is measured, but tells us nothing about the actual structure of impalpable Time. Similarly, a graduated tape, even of infinite length, is not Space itself, nor can the most exact odometer represent the road which I see as a black mirror of rain under turning wheels, hear as a sticky rustle, smell as a damp July night in the Alps, and feel as a smooth basis ${ }^{59}$.

Wbrew sugestiom Ady, która zakładała, że można poznać jakiś czas, ale do percepcji Czasu nasze zmysły nie są przystosowane, Van przeprowadził studium 'woalowatej substancji' Czasu, ilustrowane metaforami ${ }^{60}$.

Wykorzystanie synestezji do poszukiwań w zakamarkach przeszłości Johnson określa mianem „,mnemonicznej archeologii”61. Jak twierdzi Van, wydarzenia przechowywane w pamięci mają swoje barwy i w zależności od stopnia ich nasycenia można je odnieść do określonej warstwy chronologicznej. Ta teoria synestezyjnych wspomnień znalazła wyraz w autobiografii Speak, memory. Nieprzypadkowo sceny, w których na pierwszy plan wysuwa się mechanizm pamięci, nasycone są elementami wrażeń zmysłowych ${ }^{62}$.

\section{Nabokovowskie metafory międzymodalne}

Obrazowanie łączące doznania pochodzące z różnych modalności zmysłowych nie zawsze oznacza doświadczanie przez autora w danym momencie mimowolnych wrażeń synestezyjnych. Analiza przykładów pochodzących z tekstów Nabokova pokazała, że znaczna ich część jest rezultatem zamierzonych twórczych działań pisarza. Ich interpretacja prowadzi do zakwalifikowania tych

59 Ibidem, s. 541.

60 V. Nabokov, Ada albo Żar. Kronika rodzinna..., s. 673-674.

61 Д. Джонсон, Миры и антимиры Владимира Набокова..., s. 8.

62 Patrz, np.: V. Nabokov, Pamięci, przemów. Autobiografia raz jeszcze, przeł. A. Kołyszko, posł. L. Engelking, Warszawskie Wydawnictwo Literackie MUZA SA, Warszawa 2004, s. 71-74, 122, 243. 
konstrukcji do kategorii metafory literackiej obliczonej na sprowokowanie czytelnika do wysiłku intelektualnego.

1) dźwięk $\rightarrow$ (pozornie synestezyjny) kolor

Pogłębiona analiza konieczna jest w przypadku niektórych pozornie chromestezyjnych połączeń wrażeń zmysłowych. Ilustracją może posłużyć zaprezentowany już wcześniej fragment pochodzący z Maszeńki:

Ярче, веселее звезд были огненные буквы, которые высыпали одна за другой над черной крышей, семенили гуськом и разом и пропадали во тьме. «Неужели... это... возможно...»- огненным осторожным шепотом проступали буквы, и ночь одним бархатным ударом смахивала их. «Неужели... это...» - опять начинали они, крадясь по небу ${ }^{63}$.

„Ognisty szept" pojawiających się liter to nic innego, jak litery w kolorze ognistym, które z towarzyszeniem cichego dźwięku działającej elektryczności pojawiały się na neonowym szyldzie. Nie jest to zatem, jak by się zdawało po pobieżnej lekturze, szept postrzegany w ognistym kolorze.

W podobny sposób zbudowana została metaforyczna konstrukcja w Lolicie:

And then as a lovely, lonely, supercilious grove (oaks, I thought; American trees at the stage were Beyond me) started to echo greenly the rush of our car, a red and ferny road on our right turned its head before slanting into the woodland, and I suggested we might perhaps $-\ldots{ }^{64}$

'Zielone echo' - to metaforyczno-metonimiczne określenie szumu zielonych drzew w przydrożnym zagajniku, który przypominał pęd samochodu Humberta. Analogicznie też 'biała cisza' w opowiadaniu Cios skrzydła oznacza ciszę panującą na górskich stokach pokrytych białym śniegiem:

63 В. В. Набоков, Машенька..., s. 53.

64 V. Nabokov, Lolita..., s. 140. 
Он приехал в эту гостиницу, в этот морозный и модный уголок Церматта, чтобы слить впечатления белой тишины с приятностью легких и пестрых знакомств...65

‘Białe kroki’ pojawiają się natomiast w opowieści Czarodziej:

И случалось, ночью, когда всё стихало - и радиола, и вода в уборной, и белые шажки сиделки, и тот бесконечно задержанный звук (хуже любого грохота!), с которым она затворяла двери, и осторожный звон ложечки, и трык-трык аптечки, и отдаленная загробная жалоба особы - когда всё это окончательно стихало, он ложился навзничь и вызывал единственный образ, и восемью руками оплетая улыбающуюся добычу, осмью щупальцами присасываясь к её подробной наготе, наконец исходил черным туманом и терял её в черноте, а черное расползалось сплошь, да всего лишь было чернотой ночи в его одинокой спальне 6 .

Tym razem mamy do czynienia z podwójną metonimią: KROKI ZA ODGŁOS KROKÓW, KOLOR BIAŁY ZA PIELĘGNIARKĘ W BIAŁYM FARTUCHU. W rezultacie 'białe kroki' oznaczają w utworze odgłos kroków dyżurującej pielęgniarki w białym fartuchu nocą w szpitalnym korytarzu.

We fragmencie opowiadania Brzytwa mamy obraz właściciela zakładu, który ze srebrzystym brzękiem obracał korbką kasy:

$[\ldots]$ и был еще сам хозяин, - кислый толстяк, с серебряным грохотом поворачивавший ручку кассы...67

Dźwięk wywoływany kręceniem korbką przejął srebrzystą barwę od samej korbki lub innych metalowych elementów kasy.

${ }_{65}$ В. В. Набоков, Удар крыла, [w:] В. В. Набоков, Полное собрание рассказов, составление текста и примечания - А. Бабиков, Изд. «Азбука-Аттикус», Санкт-Петербург 2013, s. 63.

${ }_{66}$ В. В. Набоков, Волшебник, Изд. Сипмозиум, 2000 (wersja on-line:) http://royallib.com/book/nabokov_vladimir/volshebnik.html [dostęp 10.12.2014], s. $13-14$.

${ }^{67}$ В. В. Набоков, Бритва, [w:] В. В. Набоков, Полное собрание рассказов..., s. 211. 
$\mathrm{Na}$ jeszcze jeden przykład pozornej chromestezji wskazuje 'złoty grzmot świątyń' w opowiadaniu Słowo:

Я чувствовал, что, захвати я в горсть хоть один дрожащий отблеск, я принес бы в мою страну такую радость, что мгновенно озарились бы, закружились людские души под плеск и хруст воскресшей весны, под золотой гром проснувшихся храмов...68

Świątynie w Rosji to w przeważającej większości prawosławne cerkwie ze złoconymi często kopułami. Złoty grzmot przebudzonych świątyń oznaczać więc będzie dźwięk dzwonów rozlegający się spod złoconych kopuł cerkwi. Dźwięk ten jest szczególnie silny, uroczysty i radosny w wielkopostną sobotę, gdy zwiastuje zmartwychwstanie Jezusa - do czego nawiązuje Nabokov, pisząc o dźwiękach zmartwychwstałej przyrody. Cała konstrukcja oznacza powrót Rosji do dawnego duchowego, religijnego życia sprzed rewolucji październikowej i jest wyrazem tęsknoty Nabokova za dawnym życiem w ojczyźnie.

Ciekawym przypadkiem łączącym w sobie elementy chromestezyjne z ideostezyjnymi jest rozmowa o literaturze rosyjskiej, prowadzona przez bohaterów Daru:

Отмечаю, что у него латинское чувство синевы: lividus. Лев Толстой, тот был больше насчет лилового, - и какое блаженство пройтись с грачами по пашне босиком!69

Wtrącona mimochodem przez Godunowa-Czerdyncewa uwaga ujawnia dostrzeżone przez niego brzmieniowe podobieństwo między Leskowem i Lwem Tołstojem (Лесков - Лев Толстой) oraz ich zbliżenie do łacińskiego przymiotnika nazywającego kolor granatowy - lividus. Stąd właśnie metonimiczne w swoim charakterze określenie „łacińskie odczucie granatu” użyte zamiast „łacińska nazwa dla wrażenia koloru granatowego".

${ }_{68}$ В. В. Набоков, Слово, [w:] В. В. Набоков, Полное собрание рассказов..., s. 51.

69 В. В. Набоков, Дар..., s. 66. 
2) dotyk $\rightarrow$ (pozornie synestezyjny) kolor

Metaforyczne połączenia doznań wzrokowych ze słuchowymi nie są jedynym rodzajem zamierzonych synestezyjnych zabiegów Nabokova. $Z$ równym powodzeniem łączy on wrażenia kolorystyczne z dotykowymi oraz z odczuwaniem temperatury, odnosząc powstałe konstrukcje do stanu emocjonalnego i przeżyć swych bohaterów.

'Głęboka szkarłatna miękkość' we fragmencie z $A d y$ pozornie wygląda jak typowe skojarzenie synestezyjne rozumiane jako doznanie na poziomie neuronalnym:

She fondled him; she entwined him: thus a tendril climber coils round a column, swathing it tighter and tighter, biting into its neck ever sweeter, then dissolving strength in deep crimson softness ${ }^{70}$.

Nie chodzi tu jednak o doznania towarzyszące wrażeniom dotykowym, lecz o metonimiczny opis żeńskiego narządu płciowego podczas stosunku seksualnego: MIĘKKOŚĆ ZANARZĄD (CZĘŚĆ (CECHA) ZA CAŁOŚĆ).

3) kolor $\rightarrow$ (pozornie synestezyjny) dotyk

W metaforach łączących doznania dotykowe i wzrokowe dochodzi też niekiedy do przeniesienia zapamiętanych wrażeń dotykowych i połączenia ich z doznaniami kolorystycznymi, np.:

a) 'lepki kolor':

Куча черешен, красно и клейко черневшая перед нами, обратилась внезапно в отдельные ягоды... ${ }^{71}$

b) 'chropowaty kolor':

На лотке, среди лиловых моллюсков, пахнувших морской травой, шероховатым золотом отливали лимоны ${ }^{72}$.

70 V. Nabokov, Ada or Ardor: A Family Chronicle..., s. 141.

71 Ibidem, s. 5.

72 В. В. Набоков, Порт, [w:] В. В. Набоков, Полное собрание рассказов..., s. 85 . 
c) dotyk i namiętność - znaczna liczba metaforycznych określeń namiętności pojawia się w Adzie i w Lolicie, na przykład: 'sticky desire', któremu towarzyszy opis Ady układającej domek z kart i uwaga Vana o „magii dotyku”73. Bohater Lolity, Humbert, próbuje sobie wyobrazić, jak wyglądałby namalowany przez niego obraz w jadalni hotelu, stworzony pod wpływem żądzy i namiętności. Wśród elementów swego dzieła wymienia żądlącą czerwień oraz piekący róż ('stinging red', 'smarting pink') 74, które w kontekście opisanej sytuacji mają podtekst seksualny.

4) kolor $\rightarrow$ (pozornie synestezyjna) temperatura

a) ciepłe kolory - Humbert o Lolicie:

The bathroom door has just slammed, so one has to feel elsewhere about the house for the beautiful warm-colored prey ${ }^{75}$.

b) 'ciepłe odcienie':

[...] пестрел кругом великолепный Тиргартен, и прекрасны были теплые, рыжие оттенки листвы... ${ }^{76}$

c) ciepły blask:

Mount Russet, the forested hill behind the town, lived up to its name and autumnal reputation, with a warm glow of curly chestnut trees ${ }^{77}$.

\section{d) 'mroźny metaliczny mrok':}

В морозном металлическом мраке, желтым и красным светом горели съедобные окна ${ }^{78}$.

73 V. Nabokov, Ada or Ardor: A Family Chronicle..., s. 113.

74 V. Nabokov, Lolita..., s. 135.

75 Ibidem, s. 49.

76 В. В. Набоков, Подвиг, [w:] Владимир Набоков. Собрание сочинений в четырех томах, под ред. В. В. Ерофеева, т. 2, Издательство «Правда», Москва 1990, s. 282.

77 V. Nabokov, Ada or Ardor: A Family Chronicle..., s. 509.

78 В. В. Набоков, Приглашение на казнь..., s. 13. 
e) 'skwarny błękit':

Лепясь по крутоярам, продвигались мы под жаркой синевой 79 .

f) 'mroźny lazur':

Морозная лазурь лилась в окно 80 .

g) 'skwarny blask':

Правая сторона была в тени, по левой в жарком сиянии дрожал вдоль панели узкий ручей... ${ }^{81}$

h) 'gorące światło':

Если на аллее, под ногами, колебались кольца горячего света, то вдалеке непременно протягивалась поперек толстая бархатная полоса, за ней опять - оранжевое решето... ${ }^{82}$

i) 'gorąca ochra':

Перед школой, под кленами, солнце разбрызгалось горячей охрой83.

j) 'zimna, biała ciemność':

Он крякнул, влезая в холодную, белую темноту рубашки... ${ }^{84}$

79 Ibidem, s. 110.

80 В. В. Набоков, Удар крыла..., s. 70.

81 В. В. Набоков, Порт..., s. 84.

82 В. В. Набоков, Дар..., s. 71.

83 В. В. Набоков, Звуки, [w:] В. В. Набоков, Полное собрание рассказов..., s. 32 .

${ }^{84}$ В. В. Набоков, Подлец, [w:] В. В. Набоков, Полное собрание рассказов..., s. 260 . 
5) temperatura $\rightarrow$ (pozornie synestezyjny) kolor

Pozornie synestezyjny kolor temperatury opisany został w odniesieniu do nastoletniej bohaterki Czarodzieja, która w oczach i odczuciach pożądającego ją mężczyzny emanowała kasztanowym żarem:

На асфальтовой аллейке все рокотало от роликов, а у края панели шла частная игра в классы, - и, в ожидании своей очереди, отставя ногу, скрестив горящие руки на груди, наклонив мреющую голову, вея страшным каштановым жаром, теряя, теряя лиловое, истлевающее под страшным, неведомым ей взглядом... но еще никогда придаточное предложение его страшной жизни не дополнялось главным, и он прошел, стиснув зубы, ахая про себя и стоная, а затем мельком улыбнулся малышу, который вбежал ему в ножницы ног ${ }^{85}$.

Kolor żaru okazuje się kolorem kasztanowych włosów dziewczynki. Sam żar natomiast oznacza stopień seksualnego napięcia mężczyzny. Podobnie w kolejnym przykładzie pomarańczowy żar jest barwą blasku ognia płonącego w kominku. Kolor ognia został tym samym przeniesiony na kolor odczuwanej w jego otoczeniu temperatury:

Около четырех он спустился в просторную читальню, где оранжевым жаром дышала пасть камина... ${ }^{86}$

6) dźwięk $\rightarrow$ (pozornie synestezyjny) dotyk

Spośród innych kombinacji metaforycznych doznań zmysłowych u Nabokova znaleźć można połączenie dźwięku z dotykiem. Brzmienie telefonicznego dzwonka w Darze wywołuje wrażenie dotyku:

Вдруг, среди сгущающейся мглы, у последней заставы разума, серебром ударил телефонный звонок, и Федор Константинович перевалился ничком, падая... Звон остался в пальцах, как если бы он острекался ${ }^{87}$.

85 В. В. Набоков, Волшебник..., s. 3.

86 В. В. Набоков, Удар крыла..., s. 55.

87 В. В. Набоков, Дар..., s. 317. 
W innym przykładzie 'wilgotny szelest' określa odgłos wynikający z kontaktu pojazdu z wilgotną nawierzchnią:

Звонко посвистывая и поднимаясь (в гору) на педалях своего трехколесного велосипеда, проехал рассыльный пекарни; медленно, с влажным шорохом, прополз водометный автомобиль - кит на колесах, широко орошая асфальт ${ }^{88}$.

7) dźwięk $\rightarrow$ (pozornie synestezyjna) temperatura

a) 'gorący szept' - Emma, córka strażnika więziennego, objęła Cyncynata za szyję i na ucho próbowała opowiedzieć mu, w jaki sposób zamierza go następnego dnia uwolnić. Wypowiadane przez nią głośne słowa wprost do ucha Cyncynata wywoływały u niego odczucie gorącego, wilgotnego huku:

Обняв его за шею одной рукой, она жарко, влажно и совершенно невнятно загудела ему в ухо 89 .

Podobną sytuację znajdziemy w Lolicie: dziewczynka przytknęła usta do ucha Humberta, który usłyszał grzmot jej gorącego szeptu ('the hot thunder of her whisper') ${ }^{90}$.

b) 'zimny głos':

Вольф странно посмотрел на нее. Потом далеко кинул шишку и проговорил холодным, глухим голосом ${ }^{91}$.

8) temperatura $\rightarrow$ (pozornie synestezyjny) dotyk

Krótki fragment opowiadania Wenecjanka dostarcza nam dwóch przykładów przeniesienia określeń odnoszących się do do-

88 Ibidem, s. 295.

89 В. В. Набоков, Приглашение на казнь.., s. 86.

90 V. Nabokov, Lolita..., s. 133.

91 В. В. Набоков, Натама, [w:] В. В. Набоков, Полное собрание рассказов..., s. 140 . 
tyku do sfery temperatury. Z jednej strony mamy tu szorstki i twardy chłód cytryny, z drugiej zaś suchy żar palców podających owoc:

Не сводя глаз с ее заигравших глаз, он взял из ее руки желтый плод - и как только он ощутил его шероховатый твердый холодок и сухой жар ее длинных пальцев, невероятное блаженство вскипело в нем, сладко заклокотало 92.

9) smak $\rightarrow$ (pozornie synestezyjny) kolor

W jednym z opowiadań z kolei smak zmienia swój odcień pod wpływem rozcieńczania:

Сидя в кафе и все разбавляя бледнеющую сладость струей из сифона, он вспомнил прошлое со стеснением сердца...93

Metonimia pozwala ujrzeć w słodyczy słodki napój, kolor którego, pod wpływem domieszanej wody, stawał się coraz jaśniejszy.

Interesujący, choć rozpatrywany poza wskazanymi wyżej kategoriami, przykład widzenia słuchem prezentuje fragment powieści Zaproszenie na egzekucję:

Они были еще ближе - и теперь так торопились, что грешно было их отвлекать выстукиванием вопросов. И продолжались они позже, чем вчера, и Цинциннат лежал на плитах крестом, ничком, как сраженный солнечным ударом, и, потворствуя ряжению чувств, ясно, через слух видел потайной ход, удлиняющийся с каждым скребом...94

Cyncynat wsłuchiwał się w dźwięki dobiegające zza ścian celi i wierzył, że przyniosą mu one wolność. „Jasno widział słuchem” korytarz drążony przez nieokreślonego kogoś, kto przygotowuje

92 В. В. Набоков, Венецианка, [w:] В. В. Набоков, Полное собрание рассказов..., s. 166.

93 В. В. Набоков, Круг, [w:] В. В. Набоков, Полное собрание рассказов..., s. 380.

${ }_{94}$ В. В. Набоков, Приглашение на казнь..., s. 84. 
jego ucieczkę. Słyszane skrobania i stukania odnosił do wyobrażanego sobie, wydłużającego się z każdą chwilą korytarza, przygotowywanego na jego ucieczkę przed egzekucją.

\section{Schemat metafory synestezyjnej}

Metafory synestezyjne do złudzenia przypominają skojarzenia synestezyjne, dlatego czasem tak trudno oddzielić jedne od drugich. Biorąc jednak pod uwagę ich powszechność w języku osób, które na co dzień nie doświadczają skojarzeń międzymodalnych, uczeni od wielu lat starają się odpowiedzieć na pytania: Czy istnieją podobieństwa między sensorycznym wzorem skojarzeń synestezyjnych i wzorem synestezyjnej metafory? Czy w ogóle możliwe jest ustalenie wzoru metafory synestezyjnej? W roku 1976, w artykule Synaesthetic adjectives: a possible law of semantic change Williams przedstawił rezultaty analizy przymiotników angielskich, w znaczeniach których nastąpiło metaforyczne przesunięcie synestezyjne. Wyniki te można sformułować następująco ${ }^{95}$ : jeśli wyraz przechodzi metaforyczny transfer z jednej sfery sensorycznej do drugiej, to transfer ten dokonuje się według następującego wzoru:

kolor

$$
\text { dotyk } \rightarrow \text { smak } \rightarrow \text { zapach } \rightarrow \text { przestrzeń }
$$

dźwięk

Jak wynika z powyższego schematu, określenie odnoszące się pierwotnie do dotyku może przejść do sfery smaku, zapachu, koloru lub dźwięku, np. twarde dźwięki. Przymiotniki pierwotnie nale-

95 J. Williams, Synaesthetic adjectives: a possible law of semantic change, „Language” 1976, No 51, s. 463; podaję za: G. A. Kleparski, Kierunki typologiczne w badaniach nad zmiana znaczeniową wyrazów, „Bulletinde la Société Polonaise de Linguistique" 1999, fasc. LV, s. 85-86 (wersja online: http:/www.mimuw. edu.pl/polszczyzna/PTJ/b/b55_077-092.pdf [dostęp 10.05.2015]. 
żące do sfery przestrzeni mogą przejść do sfery koloru lub dźwięku, np. głęboki dźwięk. Natomiast wyrazy odnoszące się pierwotnie do sfery koloru mogą przejść do sfery dźwięku i vice versa, np. czysty dźwięk, krzykliwy kolor.

Senderecka twierdzi z kolei, że międzymodalne metafory zazwyczaj łączą doznania zmysłowe w kolejności typowej dla synestezji kolorowego słyszenia: wychodzą od doznania słuchowego i kierują się ku doznaniu wzrokowemu ${ }^{96}$. Ullman zaproponował następujący wzór synestezyjnych metafor:

zapach/smak $\rightarrow$ słyszenie/widzenie $\rightarrow$ dotyk,

co należy odczytać jako: zapach/smak będą ewoluować tak, by o nich mówić w terminach słyszenia/widzenia, i - podobnie - słyszenie/ widzenie będą ewoluować w kierunku możliwości mówienia o nich w terminach dotyku ${ }^{97}$.

W dążeniu do sprawdzenia słuszności twierdzeń Ullmana Sean Day przeprowadził podobne badania. Zgromadzone przez niego przykłady synestezyjnych metafor wskazały na istnienie innej regularności, którą Day ujął we wzorze ${ }^{98}$ :

słyszenie $\rightarrow$ widzenie $\rightarrow$ zapach $\rightarrow$ temperatura $\rightarrow$ smak $\rightarrow$ dotyk.

Przykłady metaforycznych konstrukcji synestezyjnych u Nabokova pozwalają dostrzec taką regularność w odniesieniu do niektórych ich odmian. Dźwięk ewoluuje tak, że można o nim mówić w kategoriach barw, a zatem schemat synestezyjnej metafory wyglądać będzie następująco:

dźwięk $\rightarrow$ kolor (słyszenie $\rightarrow$ widzenie)

Regularność zaobserwowaną przez badaczy dostrzec można też w konstrukcjach typu: ,,клейко черневшая”, ,шшероховатое золото” oraz „stinging red” i „,smarting pink'. Określenia odnoszące

96 Por.: M. Senderecka, Synestezja..., s. 274.

97 S. Ullman, Language and Style, Basil Blackwell, Oxford 1964; podaję za: S. A. Day, Synaesthesia and synaesthetic metaphors, „Psyche”, lipiec 1996, 2 (32), s. 5, http://www.theassc.org/files/assc/2358.pdf [dostęp: 4.02.2015].

98 Ibidem, s. 6. 
się pierwotnie do dotyku zostały przeniesione do sfery koloru, jak twierdził Williams. Posługując się zaś sformułowaniami Daya i Ullmana możemy powiedzieć, że kolor ewoluował tak, iż możemy o nim mówić w terminach dotyku. Zaznaczyć przy tym należy, że wniosek ten potwierdza obserwacje Ullmana, ale tylko częściowo odpowiada schematowi Daya, w którym doznania widzenia i dotyku nie występują obok siebie.

Inaczej natomiast schemat ten wyglądać będzie w przypadku pozostałych metafor. 'Каштановый жар' i 'оранжевый жар' wskazują na regularność: temperatura $\rightarrow$ kolor. W ostatnim zaś z omówionych wcześniej przykładów: „Звон остался в пальцах, как если бы он острекался", dźwięk ewoluuje tak, że mówić o nim można w kategoriach dotyku, a nie widzenia. Podobnie synestezyjne połączenie 'deep crimson softness', w którym wrażenia dotykowe wyrażone zostały w kategoriach doznań wzrokowych, przeczy zależnościom ujętym w schemacie Daya.

Biorąc pod uwagę wszystkie zaobserwowane rodzaje synestezyjnych konstrukcji metaforycznych, które pojawiają się w utworach Nabokova, można spróbować sporządzić schemat zależności między poszczególnymi doznaniami sensualnymi:

dotyk

dźwięk

kolor

temperatura

smak

Trudno tu jednak mówić o regularnościach czy nawet tendencjach w metaforycznym łączeniu wrażeń zmysłowych. Przypo- 
mnijmy bowiem, że większość włączonych do schematu odmian obejmuje nie więcej niż dwa przykłady ilustracyjne. Zaprezentowane przykłady pozwalają jednak zauważyć, że metaforyczne kombinacje skojarzeń sensorycznych często odbiegają od istniejących w nauce wzorców, podobnie jak cała twórczość Nabokova wykracza poza nurty i konwenanse.

\section{Metafory łączące doznania zmysłowe z niezmysłowymi}

Rezultaty badań nad konceptualną odmianą synestezji i nad ideostezją pozwalają znaleźć uzasadnienie dla włączenia do niniejszych rozważań również tych przypadków, w których zaobserwować można projekcję cech doznań zmysłowych na pojęcia niezmysłowe. Transfer odbywa się zazwyczaj w kierunku 'modalność zmysłowa' $\rightarrow$ 'pojęcie niezmysłowe', choć nie jest to jedyna możliwa kombinacja. Nierzadko to właśnie wrażenia sensoryczne przedstawiane są w sposób typowy dla obiektów świata materialnego.

Przykłady przyporządkowania doznań sensorycznych do niezmysłowych pojęć zostaną zaprezentowane w kategoriach wyznaczonych przez rodzaje zmysłów. Podobnie jak miało to miejsce podczas omawiania synestezji, do wrażeń zmysłowych zaliczone zostały również temperatura i ból, jak to jest przyjęte w literaturze naukowej dotyczącej zjawisk synestezyjnych.

\section{Barwa}

1) kolor dźwięku:

a) barwa słów:

W Adzie natkniemy się na opis barwy słów: 'ugly dark words' ${ }^{99}$, które przerażały Adę i tę samą rolę miały odegrać w stosunku do zakochanej w Vanie Lucette, by zniechęcić ją do zabiegania o kochanka. Owymi mrocznymi słowami była prawda o bliskim pokrewieństwie między Vanem i Lucette.

99 V. Nabokov, Ada or Ardor: A Family Chronicle..., s. 214. 
b) kolor śpiewu ptaków w osłonecznionym lesie:

Страстно хотелось все испытать, до всего добраться, пропустить сквозь себя пятнистую музыку, пестрые голоса, крики птиц, и на минуту войти в душу прохожего... ${ }^{100}$

\section{2) kolor powietrza}

a) pomarańczowy - kolor nieba po zachodzie słońca:

One hates to write about those matters, it all comes out so improper, esthetically speaking, in written description, but one cannot help recalling in this ultimate twilight (where minor artistic blunders are fainter than very fugitive bats in an insect-poor wilderness of orange air) that Lucette-s dewy little contributions augmented rather than dampened Van's invariable reaction to the only and main girl's lightest touch, actual or imagined ${ }^{101}$.

b) zielony - kolor powietrza w dzień rozpoczęcia wspólnej podróży Humberta i Lo:

The air, despite a steady drizzle beading it, was warm and green... ${ }^{102}$

c) blady - kolor powietrza o brzasku w dzień egzekucji Cyncynata:

теперь воздух бледен, а я так озяб ${ }^{103}$.

d) kolorowy - barwne powietrze zachodu słońca:

They passed through a dark archway, and as they came out into the colored air of a delicate sunset, he stopped her and gave her the note he had written $^{104}$.

100 В. В. Набоков, Совершенство, [w:] В. В. Набоков, Полное собрание рассказов..., s. 354.

101 V. Nabokov, Ada or Ardor: A Family Chronicle..., s. 205.

102 V. Nabokov, Lolita..., s. 116.

103 В. В. Набоков, Приглашение на казнь..., s. 111.

104 V. Nabokov, Ada or Ardor: A Family Chronicle..., s. 386. 
3) kolor cechy charakteru i zachowania:

o Vana:

a) matowa chciwość - cecha Lucette dotyczyła zazdrości

Her half-veiled gaze dwelt upon him with heavy, opaque greed $^{105}$.

b) złoty kolor osoby:

'golden pet' 106 - Humbert o Lolicie.

c) czarny kolor spojrzenia:

Ravishment - because of her pale, voluptuous, impermissible skin, her hair, her legs, her angular movements, her gazelle-grass odor, the sudden black stare of her wide-set eyes, the rustic nudity under her dress... ${ }^{107}$

4) kolor myśli (poglądów, opinii, mniemania):

a) mgliste - podkolorowane:

Z jednej strony mamy 'mgliste wyobrażenie' na jakiś temat, dotyczące na przykład wiedzy Ady o sposobach odbywania stosunków płciowych istot ludzkich, w metonimicznym określeniu w słowach:

She had still been rather hazy about the way human beings mated ${ }^{108}$.

$\mathrm{Z}$ drugiej strony natomiast, w tym samym fragmencie powieści Van mówi o wspomnieniach Ady, wyolbrzymionych, sztucznie podkolorowanych światłem późniejszych wydarzeń:

Stupidly exaggerated [commented Van] Also, I suppose, artificially recolored in the lamplight of later events as revealed still later ${ }^{109}$.

105 Ibidem, s. 478.

106 V. Nabokov, Lolita..., s. 234.

107 V. Nabokov, Ada or Ardor: A Family Chronicle..., s. 59.

108 Ibidem, s. 111.

109 Ibidem, s. 112. 
b) mroczny, ciemny:

- zamiary Vana w mrocznych zakątkach umysłu w stosunku do męża Ady:

Van had murdered good Andrey Andreevich Vinelander so often, so thoroughly, at all the dark crossroads of the mind, that now the poor chap, dressed in a hideous, funereal, double-breasted suit, with those dough-soft features slapped together anyhow, and those sad-hound baggy eyes, and the dotted lines of sweat on his brow, presented all the depressing features of an unnecessary resurrection ${ }^{110}$.

- wątpliwości: 'dark doubts'111.

c) 'promyki nadziei' Humberta na zaaranżowanie spotkania z Lolitą:

The week of scattered showers and shadows which elapsed after our last visit to the motionless sands of Hourglass Lake was one of the gloomiest I can recall. Then came two or three dim rays of hope - before the ultimate sunburst ${ }^{112}$.

d) szary: metody wychowawcze szkoły z internatem, w której Charlotta zamierzała umieścić Lolitę, oznaczają surową dyscyplinę nadającą szkole opinię domu poprawczego:

[...] an application not to St. A. but to another boarding school which was said to be so harsh and gray and gaunt in its methods (although supplying croquet under the elms) as to have earned the nickname of Reformatory for Young Ladies ${ }^{113}$.

110 V. Nabokov, Ada or Ardor: A Family Chronicle..., s. 512.

111 V. Nabokov, Lolita..., s. 118.

112 Ibidem, s. 90.

113 Ibidem, s. 99. 
5) kolor stanu emocjonalnego, nastroju, uczuć

a) czarny - opis nastroju Corduli w Adzie:

Her mood was even blacker than his ${ }^{114}$.

b) złoty - jest odzwierciedleniem koloru spódniczki (husked-corn), którą Ada miała na sobie tego dnia. Złoty przypływ narastającej radości oznacza więc radość odczuwaną pod wpływem obrazu Ady w spódniczce koloru łuskanej kukurydzy, utrwalonego pod powiekami Vana:

Van closed his eyes in order better to concentrate on the golden flood of swelling joy ${ }^{115}$.

c) szary - kolor szlafroka i kanapy koresponduje z nienajlepszym stanem psychofizycznym bohatera. Szarość i przeciwstawna mu wielobarwność mają pokazać złe i dobre chwile w życiu. Proporcje między nimi w życiu Lucette przedstawia porównanie istnienia bohaterki do „obrazu namalowanego na powietrzu”:

'I'm like Dolores - when she says she's 'only a picture painted on air.' [...] It's exactly my sense of existing - a fragment, a wisp of color ${ }^{116}$.

d) niebieski, różowy - każde $\mathrm{z}$ dwóch przeciwstawionych sobie wzajemnie typów zachowania i nastroju Lolity zostało opatrzone kolorem: nadąsanie niebieskim, radość zaś różowym:

A combination of naïveté and deception, of charm and vulgarity, of blue sulks and rosy mirth, Lolita, when she chose, could be a most exasperating brat ${ }^{117}$.

114 V. Nabokov, Ada or Ardor: A Family Chronicle..., s. 167.

115 Ibidem, s. 281.

116 V. Nabokov, Ada or Ardor: A Family Chronicle..., s. 464.

117 V. Nabokov, Lolita..., s. 147-148. 
e) blady - kolor niemocy:

[...] жиденькая, удобозапоминаемая лирика конца прошлого века, жадно ждущая переложения на музыку, как избавления от бледной немочи слов, проходило совершенно мимо него ${ }^{118}$.

f) słoneczny - 'słoneczny spokój':

In the early afternoon he descended with his two suitcases into the sunny peace of the little rural station whence a winding road led to Ardis Hall, which he was visiting for the first time in his life ${ }^{119}$.

g) złocisty - 'złocisty spokój' ('golden peace'120) jest odczuwany przez Humberta w domu Lolity, pani Richardowej F. Schiller, po informacji o człowieku, który pomógł wymknąć się dziewczynce z jego rąk. Paradoksalnie właśnie wtedy, gdy czytelnik spodziewa się gwałtownego wybuchu emocji, następuje spokój wynikający z rozwiązania zagadki i dostrzeżenia logicznego porządku wydarzeń.

h) bezbarwny - 'bezbarwna nuda' Ganina:

Ничто не украшало его бесцветной тоски, мысли ползли без связи, сердце билось тихо, белье докучливо липло к телу' ${ }^{121}$.

Jak można zauważyć, barwy achromatyczne (szary, czarny) wiążą się z negatywną oceną stanu emocjonalnego, ze złym nastrojem. Obecność barw chromatycznych natomiast jest oznaką dobrego samopoczucia. Na taką właśnie funkcję kolorów wskazuje Nabokov w Adzie, gdy opisuje stan ponarkotycznego otępienia myśli u Demona:

118 В. В. Набоков, Дар..,, s. 133.

119 V. Nabokov, Ada or Ardor: A Family Chronicle..., s. 34.

120 V. Nabokov, Lolita..., s. 272.

121 В. В. Набоков, Машенька..., s. 47. 
The dragon drug had worn off: its aftereffects are not pleasant, combining as they do physical fatigue with a certain starkness of thought as if all color were drained from the mind. Now clad in a gray dressing gown, Demon lay on a gray couch in his third-floor study ${ }^{122}$.

6) kolor czynów i wydarzeń:

a) czarny - na bazie angielskiego 'that's very kind of you' skonstruowana została metafora 'that's very black of you' ${ }^{123}$. Nabokov nie pozostawił jednak czytelnika bez wyjaśnień odnośnie do jej znaczenia:

„That's very black of you, dad", said pleased Van, using a slang phrase he had learned from his tender young nurse, Ruby, who was born in the Mississippi region where most magistrates, public benefactors, high priests of various so-called "denominations", and other honourable and generous men, had the dark or darkish skin of their West-African ancestors, who had been the first navigators to reach the Gulf of Mexico.

Metaforyczne użycie koloru nie oznacza tu bynajmniej negatywnej oceny czyichś postępków czy zamiarów, lecz przeciwnie - okazuje się slangowym wyrażeniem użytym przez Vana dla określenia postępowania jego ojca, typowego dla działań podejmowanych przez ciemnoskórych szczodrych i szanowanych osobistości regionu Missisipi.

b) mroczny, ciemny - insynuacje: 'nothing beyond darkly insinuating' ${ }^{\prime 24}$.

7) kolor (pory) dnia, godziny, czasu:

a) niebieski, ciemnoniebieski dzień - opisuje bezchmurne niebo zarówno zimowego, jak i letniego gorącego dnia.

122 V. Nabokov, Ada or Ardor: A Family Chronicle..., s. 439.

123 Ibidem, s. 241.

124 V. Nabokov, Lolita..., s. 172. 
It's a blue, icy, breathless day ${ }^{125}$.

Там, на койке, уже ждал адвокат, сидел, погруженный по плечи в раздумье, без фрака (забытого на венском стуле в зале суда, - был жаркий, насквозь синий день)... ${ }^{126}$

b) mleczny dzień:

День был холодноватый, молочный; белые, растрепанные облака поднимались навстречу ему в голубом пролете между домов ${ }^{127}$.

c) jasny / ciemny - określenie godziny:

Van endeavoured to follow the same line of logic but could not forget the shame and the agony even while reaching heights of happiness he had not known at his brightest hour before his darkest one in the past ${ }^{128}$.

Kontrastowe użycie nazw barw achromatycznych odpowiada skrajnym uczuciom: jasny szczęściu, ciemny porażce i nieszczęściu. „Czarna godzina” jest powszechnie znanym i używanym frazeologizmem oznaczającym wyjątkowo trudny okres w życiu.

\section{d) perłowy ranek:}

We (mother Haze, Dolores and I) were to go to Our Glass Lake this afternoon, and bathe, and bask; but a nacreous morn degenerated at noon into rain, and Lo made a scene'129.

e) oślepiająco zielone poranki:

[...] ему было жаль своей тогдашней молодости - и всего связанного с нею - злости, неуклюжести, жара, - и ослепительно-зеленых утр, когда в роще можно было оглохнуть от иволог ${ }^{130}$.

125 V. Nabokov, Ada or Ardor: A Family Chronicle..., s. 423.

126 В. В. Набоков, Приглашение на казнь..., s. 5.

127 В. В. Набоков, Машенька..., s. 56.

128 V. Nabokov, Ada or Ardor: A Family Chronicle..., s. 431.

129 V. Nabokov, Lolita..., s. 43.

130 В. В. Набоков, Круг..., s. 380. 
f) bladoniebieskie popołudnie - 'ciepło bladobłękitnego popołudnia’ w jednej z mijanych miejscowości po zniknięciu Lolity:

One day, soon after her disappearance, an attack of abominable nausea forced me to pull up on the ghost of an old mountain road that now accompanied, now traversed a brand new highway, with its population of asters bathing in the detached warmth of pale-blue afternoon in late summer ${ }^{131}$.

g) morelowo-czarny wieczór:

Uzasadnienie opisu wieczornej scenerii za pomocą takich właśnie barw przedstawić można, cytując dłuższy, wprowadzający go fragment:

$[\ldots]$ indeed, it may well be that the very attraction immaturity has for me lies not so much in the limpidity of pure young forbidden fairy child beauty as in the security of a situation where infinite perfections fill the gap between the little given and the great promised - the great rosegray never-to-be-had. Mes fenêtres! Hanging above blotched sunset and welling night, grinding my teeth, I would crowd all the demons of my desire against the railing of a throbbing balcony: it would be ready to take off in the apricot and black humid evening... ${ }^{132}$

Morelowy i czarny, dwa kolory wieczoru, z jednej strony symbolizują odchodzący dzień, $\mathrm{z}$ drugiej natomiast następującą po nim noc. Nie jest to jednak jedyna interpretacja barw. Na inne wyjaśnienie wskazują wcześniejsze wypowiedzi narratora i przeciwstawienie 'podarowanej odrobiny' oraz 'obiecanego bezmiaru niedostępnego szaroróżu ${ }^{133}$, przy czym przeżyte chwile wyobrażone są przez kolor morelowy, rozczarowanie zaś związane z niespełnionymi obietnicami - przez czarny.

131 V. Nabokov, Lolita..., s. 307.

132 Ibidem, s. 264.

133 Tłumaczenie fraz podaję według: V. Nabokov, Lolita, przeł. M. Kłobukowski, Wydawnictwo Da Capo, Warszawa 1997, s. 320. 
h) przezroczysto-granatowy wieczór:

И вот однажды вечером - в один из тех осенних прозрачно-синих вечеров, когда больше боишься старости, нежели смерти... ${ }^{134}$

i) ciemny:

- pauza podczas rozmowy Vana z ojcem dobiegła mrocznego kresu, to znaczy padły pełne wyrzutów, nieprzyjemne słowa Demona, poirytowanego zachowaniem syna wskazującym na lekceważenie lub przynajmniej obojętność wobec ujawnionej jego relacji z przyrodnią siostrą:

The most protracted of the several pauses having run its dark course, Demon's voice emerged to say, with a vigor that it had lacked before: „Van, you receive the news I import with incomprehensible calmness. I do not recall any instance, in factual or fictional life, of a father's having to tell his son that particular kind of thing in these particular circumstances. But you play with a pencil and seem as unruffled as if we were discussing your gaming debts or the demands of a wench knocked up in a ditch"135.

- o ciemnym dniu mówi też Cyncynat w Zaproszeniu na egzekucję, który w celi oczekuje na wykonanie wyroku, przesunięte na bliżej nieokreślony czas:

Но для меня так темен ваш день, так напрасно разбередили мою дремоту136.

- nieco inne znaczenie ciemny kolor przybiera w słowach Humberta, który ciemną przeszłość najwidoczniej utożsamia z czasami wczesnego dzieciństwa:

134 В. В. Набоков, Бахман, [w:] В. В. Набоков, Полное собрание расска3ов..., s. 171 .

135 V. Nabokov, Ada or Ardor: A Family Chronicle..., s. 441-442.

136 В. В. Набоков, Приглашение на казнь..., s. 118. 
My very photogenic mother died in a freak accident (picnic, lightning) when I was three, and, save for a pocket of warmth in the darkest past, nothing of her subsists within the hollows and dells of memory... ${ }^{137}$

j) czarny czas:

- w Lolicie oznacza wydarzenie, które pokrzyżowało plany Humberta i położyło kres rozkoszom dni spędzanych z pasierbicą. 'Ryczący podmuch czarnego czasu' upodobniony został do silnego podmuchu wiatru po otwarciu bocznych drzwi podczas lotu samolotem:

[...] the general impression I desire to convey is of a side door crashing open in life's full flight, and a rush of roaring black time drowning with its whipping wind the cry of lone disaster ${ }^{138}$.

- może też opisywać to, co nieznane. Tak jest w przypadku pośmiertnej przyszłości, istnienie której autor poddaje w wątpliwość:

$[\ldots]$ there is the featureless pseudo-future, blank and black, an everlasting nonlastingness, the crowning paradox of our boxed brain's eschatologies! 139

k) granatowy wieczór:

[...] это было так недавно, в синий, разноцветный фейерверочный вечер... ${ }^{140}$

1) szary czas - oznacza podeszły wiek Vana: „static grey time" 141 .

8) kolor znaku graficznego:

a) barwne spojrzenie utożsamione ze znakiem graficznym:

137 V. Nabokov, Lolita..., s. 10.

138 Ibidem, s. 254.

139 V. Nabokov, Ada or Ardor: A Family Chronicle..., s. 585.

140 В. В. Набоков, Подлец..., s. 257.

141 V. Nabokov, Ada or Ardor: A Family Chronicle..., s. 569. 
Sometimes [...], while Lolita would be haphazardly preparing her homework, sucking a pencil, lolling sideways in an easy chair with both legs over its arm, I would shed all my pedagogic restraint, dismiss all our quarrels, forget all my masculine pride - and literally crawl on my knees to your chair, my Lolita! You would give me one look - a gray furry question mark of a look: „Oh no, not again" (incredulity, exasperation); for you never deigned to believe that I could, without any specific designs, ever crave to bury my face in your plaid skirt, my darling! 142

Na pierwszy rzut oka wydawać się może, że szary, puchaty znak zapytania jest wyrazem Nabokovowskich doznań typu grafem-kolor. Istnieją jednak poważne przesłanki ku temu, by przykład ten uznać za metaforę literacką. Znak zapytania symbolizuje tu pytające spojrzenie Lolity, poirytowanej ciągłymi seksualnymi zabiegami Humberta. Szary kolor znaku zapytania, widziany oczami mężczyzny, odnosi go do dziewczynki, nawiązując do jej nazwiska (Haze), oznaczającego mgłę i wiążącą się z nią barwę.

b) litera neonu, zauważonego przez Humberta podczas spaceru ulicami odwiedzanego miasta. Kontur godła restauracji, wielki dzban z kawą, gasł i na nowo zapalał się, jakby kończyło się jego szmaragdowe życie i po chwili ulegało wskrzeszeniu:

Some way further cross the street, neon lights flickered twice slower than my heart: the outline of a restaurant sign, a large coffee-pot, kept bursting, every full second or so, into emerald life, and every time it went out, pinkt letters saying Fine Foods relayed it, but the pot could still be made out as a latent shadow teasing the eye before its next emerald resurrection ${ }^{143}$.

Nadawanie barwom cech charakteru

a) 'gay' (wesoły):

$[\ldots]$ her [Marina's] domestic gray dress with the pink fichu was quite gay enough, she declared, for an old lady"144.

\footnotetext{
142 V. Nabokov, Lolita..., s. 192.

143 V. Nabokov, Lolita..., s. 282.

144 V. Nabokov, Ada or Ardor: A Family Chronicle..., s. 269.
} 
b) 'enjoy themselves in good company' (towarzyskie):

One could make out the geometry of the streets between blocks of red and gray roofs, and green puffs of trees, and a serpentine stream, and the rich, ore-like glitter of the city dump, and beyond the town, roads crisscrossing the crazy quilt of dark and pale fields, and behind it all, great timbered mountains. But even brighter than those quietly rejoicing colors - for there are colors and shades that seem to enjoy themselves in good company - both brighter and dreamier to the ear than they were to the eye, was that vapory vibration of accumulated sounds... ${ }^{145}$

'Cicho rozradowane barwy'146, wśród których znalazły się: czerwona (red), szara (gray), zielona (green), ciemna (dark) i jasna (pale), rozkoszowały się wzajemnie swym dobrym towarzystwem.

c) 'smiling' (uśmiechnięte):

The creature was painted a smiling red with yellow intervals between black blotches; a row of blue crescents ran along the inside of the toothed wing margins ${ }^{147}$.

\section{Dźwięk}

1) dźwięk uczucia - 'szum szczęścia':

His love for Ada was a condition of being, a steady hum of happiness unlike anything he had met with professionally in the lives of the singular and the insane ${ }^{148}$.

2) uczucie, nastrój dźwięku:

a) posępność - dźwięk zegara:

145 V. Nabokov, Lolita..., s. 307.

146 Polski wariant podaję według: V. Nabokov, Lolita, przeł. M. Kłobukowski..., s. 372 .

147 V. Nabokov, Look at the Harlequins!, McGraw-Hill Book Company, New York 1974, s. 108.

148 V. Nabokov, Ada or Ardor: A Family Chronicle..., s. 574. 
Опять с банальной унылостью пробили часы ${ }^{149}$ - posępność wynika z usłyszanego przez Cyncynata wyroku śmierci (z posępnością odezwał się zegar).

b) samozadowolenie - w odczuciach Cyncynata, na widok Emmy, córki strażnika, stuk za ścianą więziennej celi wydał mu się zadowolony z siebie:

Вдруг стало светлее, - хотя не по-дневному, - и вот стук сделался определенным, довольным собой ${ }^{150}$.

c) radość, wesołość:

- w Splendorze, w opisie zabaw Martina, Koli i Lidy nad brzegiem morza, dźwięk napływających fal ma określony kształt i nastrój:

Нарастала, закипала пеной и кругло опрокидывалась волна, стелилась, взбегая по гальке, и, не удержавшись, соскальзывала назад при глухом бормотании разбуженных камушков, и не успевала втянуться, как уже новая, с тем же круглым, веселым плеском, опрокидывалась и прозрачным пластом вытягивалась до предела, положенного ей 151 .

- wesoła cisza ogrodu i lasu, która dysponuje bliżej nieokreśloną wiedzą, jest doznaniem Martina, zmęczonego wielogodzinną podróżą samochodem:

$[\ldots]$ в глубине, в еловом бору, сразу за садом, и на мягкой дороге, ведущей в деревню, была прохладная, веселая, что-то знающая тишина... ${ }^{152}$

Materializacja dźwięków

a) zmięte dźwięki:

Примятые звуки постепенно начинали расправляться ${ }^{153}$.

149 В. В. Набоков, Приглашение на казнь.., s. 6.

150 Ibidem, s. 42.

151 В. В. Набоков, Подвиг..., s. 166.

152 В. В. Набоков, Подвиг..., s. 184.

153 В. В. Набоков, Приглашение на казнь.., s. 58. 
b) ulotny cień głosu:

Мне вспоминался телефон, бегущая тень твоего голоса ${ }^{154}$.

c) wielokątny dźwięk:

Пожилой прохожий в черной фетровой шляпе остановился, глядя ему вслед, и грубо сказал что-то, - но тут же, в виде благого возмещения убытка, слепой, сидящий с гармоникой спиной к каменной ограде, пробормотал, как ни в чем ни бывало, просьбу о малой милости, выжимая многоугольный звук (странновсе же, - ведь он должен был слышать, что я бос) ${ }^{155}$.

d) okrągły dźwięk gongu:

Снизу донесся круглый, сдержанный обеденный гонг ${ }^{156}$.

e) kwadratowe echo:

The car vanished while the square echo of its slammed door was still suspended in mid-air like an empty picture frame of ebony ${ }^{157}$.

f) owiewająca cisza:

Керн постоял в лиловых тенях, и внезапно знакомым ужасом пахнула на него тишина 158 .

\section{Smak}

1) smak grzechu

154 В. В. Набоков, Благость, [w:] В. В. Набоков, Полное собрание рассказов..., s. 82.

155 В. В. Набоков, Дар..., s. 311.

156 В. В. Набоков, Венецианка..., s. 164.

${ }_{157}$ V. Nabokov, Bend Sinister, Henry Holt and Company, New York 1947, s. 43.

158 В. В. Набоков, Удар крыла..., s. 55. 
O „smacznym grzechu” wspomina Van w odniesieniu do sytuacji, gdy Ada tuż po swoich dwunastych urodzinach próbowała zaprzestać obgryzania paznokci ${ }^{159}$ :

True, one could list some compensations - such as a blessed lapse into delicious sin at Christmas, when Culex chateaubriandi Brown does not fly.

Ponieważ jest on wymieniony jako jedna z rekompensat za ulubiony nałóg i pojawia się w kontekście Bożego Narodzenia, mamy powód twierdzić, że tym razem chodzi o objadanie się smakołykami, a nie o grzech kazirodztwa. Wskazuje na to też druga część zdania. W Notach do „Ady” autorstwa Vivian Darkbloom (anagram Nabokova) czytamy, że Culex chateaubriandi jest łacińską nazwą komara Chateaubrianda, gatunku wymyślonego przez pisarza ${ }^{160}$. Annapaola Cancogni dostrzega tu jednak celowy zabieg auto$\mathrm{ra}^{161}$. Jak się okazuje, najprawdopodobniej nie chodzi tylko o nazwę owada, ale o fakt, że jest on powszechnie znany jako cousin. $\mathrm{Z}$ kolei niewielka zmiana liter w wyrazie insect prowadzi do incest (kazirodztwo). Aluzja dotyczy zatem kazirodczych relacji między przyrodnim rodzeństwem, które w tym czasie nie zachodziły.

2) smak ciała

M'sieur Pierre wyjaśniał dyrektorowi więzienia, że więźniom skazanym na śmierć najtrudniej zapomnieć kobietę, jej 'smaczne ciało’ i rozkosze fizycznych kontaktów z nią:

Я отметил, Родриг Иванович, что мужчине, осужденному на смерть, труднее всего забыть женщину, вкусное женское тело ${ }^{162}$.

159 V. Nabokov, Ada or Ardor: A Family Chronicle..., s. 105.

160 V. Nabokov, Ada albo Żar. Kronika rodzinna..., s. 740.

161 Patrz: A. Cancogni, Nabokov and Chateaubriand, [w:] V. E. Alexandrov (ed.), The Garland Companion to Vladimir Nabokov, Routledge, New York 1995 , s. 384.

162 В. В. Набоков, Приглашение на казнь.., s. 87. 


\section{3) smak słów}

Podczas gry w scrabble Ada okazuje się doskonałym graczem i ku zaskoczeniu Vana buduje nadzwyczaj długie kombinacje liter, układając je w 'apetyczne słowa':

On the Scrabble board, however, this same wild and weak Ada was transformed into a sort of graceful computing machine, endowed, moreover, with phenomenal luck, and would greatly surpass baffled Van in acumen, foresight and exploitation of chance, when shaping appetizing long words from the most unpromising scraps and collops ${ }^{163}$.

\section{4) smak czasu}

Van rozmyśla o przenikaniu się przeszłości z przyszłością i o walorach przyszłych wspomnień, częścią których będzie obiektywna percepcja teraźniejszości - jej smak i blask:

In full, deliberate consciousness, at the moment of the hooded click, he bunched the recent past with the imminent future and thought to himself that this would remain an objective perception of the real present and that he must remember the flavor, the flash, the flesh of the present (as he, indeed, remembered it half a dozen years later - and now, in the second half of the next century) $)^{164}$.

\section{5) smakować wrażenia percepcyjne}

Van smakował doznania dotykowe podczas relacji z Adą i Lucette:

Detachedly, merely tactually, as if he had met those two slow-moving, hip-swaying graces only that night, Van, while steering them through a doorway [...], placed one palm, the left, on Ada's long bare back and the other on Lucette's spine, quite as naked and long [...]. Detachedly, he sifted and tasted this sensation, then that. His girl's ensellure was hot ivory; Lucette's was downy and damp ${ }^{165}$.

163 V. Nabokov, Ada or Ardor: A Family Chronicle..., s. 225.

164 Ibidem, s. 402.

165 V. Nabokov, Ada or Ardor: A Family Chronicle..., s. 413-414. 
6) smak uczynków

- upojenie winem uczciwości, słodycz wzajemnych usług:

Александра Яковлевна признавалась мне, что, когда идет за покупками в знакомые лавки, то нравственно переносится в особый мир, где хмелеет от вина честности, от сладости взаимных услуг, и отвечает на суриковую улыбку продавца улыбкой лучистого восторга ${ }^{166}$.

7) posmak

- w znaczeniu: odczuwane, nasuwające się wrażenie, cecha czegoś; wizje i sny mogą mieć 'posmak wiedzy uprzedniej' ('precognitive flavor') $)^{167}$ :

Allied to the professional and vocational dreams are „dim-doom" visions: fatidic-sign nightmares, thalamic calamities, menacing riddles. Not infrequently the menace is well concealed, and the innocent incident will turn out to possess, if jotted down and looked up later, the kind of precognitive flavour that Dunne has explained by the action of „reverse memory” 168 .

Zarówno język rosyjski, jak i angielski znają wiele słów na określenie smaku. W jednym z nich jednak Nabokov ma szczególne upodobanie i z ogromnym twórczym rozmachem posługuje się nim w różnorodnych kontekstach. Słodycz i określenie 'słodki' znajdują swoje zastosowanie zarówno w odniesieniu do ludzi, pojęć abstrakcyjnych, przedmiotów, jak i wielu innych obiektów Nabokovowskiego świata fikcji literackiej. Dominujące znaczenie przymiotnika „słodki” w przytoczonych frazach można przy tym określić jako 'wywołujący miłe uczucie', 'będący przejawem czułości':

1) Określenia dotyczące osób, np.:

- 'the sweet cousin'169, 'sweet Cordula!' 170 - określenia Corduli w Adzie,

\footnotetext{
166 В. В. Набоков, Дар..., s. 7.

167 Por.: V. Nabokov, Ada albo Żar. Kronika rodzinna..., s. 432.

168 V. Nabokov, Ada or Ardor: A Family Chronicle..., s. 361.

169 Ibidem, s. 167.

170 Ibidem, s. 458.
} 
- 'sweet, dear Marina'171,

- 'sweet sad daughter' - słodka córka Alonsa, specjalisty od basenów ${ }^{172}$,

- 'sweet and sleepy' Ada ${ }^{173}$, 'the sweet girl'174 - opis Ady,

- Humbert o Lolicie: „She was musical and apple-sweet”"175, 'sweet girleen'176, 'sweet fool'177, 'American sweet immortal dead love' ${ }^{178}$,

- 'Sweetness' - słodycz Ady:

Old Demon, iridescent wings humped, half rose but sank back again, enveloping Ada with one arm, holding his glass in the other hand, kissing the girl in the neck, in the hair, burrowing in her sweetness with more than an uncle's fervor ${ }^{179}$.

- 'sweetness of smile' - 'słodycz uśmiechu' Ady ${ }^{180}$,

- 'sweetness' - określenie przez Vana pośladków Ady na swoich kolanach:

He recalled, in passing, the sweetness in his lap, her round little bottom, her prasine eyes as she turned toward him... ${ }^{181}$,

- 'to sweeten' - dodać pewnych cech, by polepszyć profil, wizerunek Lucette:

171 Ibidem, s. 269.

172 Ibidem, s. 399.

173 Ibidem, s. 438.

174 Ibidem, s. 119.

175 V. Nabokov, Lolita..., s. 59.

176 Ibidem, s. 95.

177 Ibidem, s. 160.

178 Ibidem, s. 280.

179 V. Nabokov, Ada or Ardor: A Family Chronicle..., s. 245.

180 Ibidem, s. 286.

181 Ibidem, s. 367. 
Her Irish profile sweetened by a touch of Russian softness, which adds a look of mysterious expectancy and wistful surprise to her beauty... ${ }^{182}$

2) Określenia dźwięków i rytmu:

- 'sweet ringing voice' - głos Vana ${ }^{183}$,

- 'Lolita's soft sweet chuckle'184 - słodki chichot Lolity,

- słodko chlupiąca wilgoć w gardle:

Марфиньке всякие фрукты полезны», - с какой-то сладко-хлюпающей сыростью в горле говорила ты, собираясь вся в одну сырую, сладкую, проклятую складочку... ${ }^{185}$,

- słodkie rytmy poszukiwań:

Он убедился, - да, это именно к нему идут, его хотят спасти, - и, продолжая постукивать в наиболее болезненные места камня, он вызывал - в другом диапазоне и ключе - полнее, сложнее, слаще, - повторение тех нехитрых ритмов, которые он предлагал ${ }^{186}$,

- rodzaj muzyki, tańca, posiłku, czasopisma i inne rzeczy, które znalazły się na liście upodobań tytułowej bohaterki, i które nic nie znaczyły dla Humberta:

Mentally, I found her to be a disgustingly conventional Little girl. Sweet hot jazz, square dancing, gooey fudze sundaes, musicals, movie magazines and so forth - these were the obvious items in her list of beloved things ${ }^{187}$,

- słodki zgiełk:

Он вздохнул глубоко, и почудились мне вновь - тучи шатучие, высокие волны листвы, блестки бересты что брызги пены да вечный, сладостный гул... 188

182 Ibidem, s. 461.

183 Ibidem, s. 179.

184 V. Nabokov, Lolita..., s. 50.

185 В. В. Набоков, Приглашение на казнь..., s. 81.

186 Ibidem, s. 80.

187 V. Nabokov, Lolita..., s. 148.

188 В. В. Набоков, Нежить..., s. 48. 
3) Określenia (pory) dni, czasu:

- the sweet summer day - słodkie dni lata, podczas których między Adą i Vanem dochodziło do zbliżeń. Nie bez znaczenia pozostają starania Vana, by sytuacje te miały miejsce:

As to ambitious, incompetent and temperamental Lucette, she had to be, even at twelve, discreetly advised by Van who did so chiefly because it saved time and brought a little closer to blessed moments when she could be bundled off to the nursery, leaving Ada available for the third or fourth little flourish of the sweet summer day ${ }^{189}$,

- 'sweet torrid and horrid nights' - opis nocy pełnych namiętności w Adzie $e^{190}$,

- 'the active sweet-swarming spring dusk' - określenie wiosennego półmroku ${ }^{191}$,

- widok z tarasu więzienia w upalny dzień skłonił Cyncynata do refleksji: „Сладко дремало время”192.

4) Określenia uczuć:

- 'the sweet revenge' - słodka zemsta w słowach skierowanych do krytyków, którzy zarzucali autorowi zbytnie przywiązanie do szczegółu:

No accursed generalized, with a half-penny mind and dry-fig heart, would be able to explain (and this is my sweetest revenge for all the detractions my lifework has met with) the individual vagaries evolved in those and similar matters ${ }^{193}$.

- uczucie Humberta, gdy odnalazł Lolitę na liście obecności uczniów jej klasy:

So strange and sweet was it to discover this "Haze Dolores" (she!) in its special bower of names, with its bodyguard of roses - a fairy princess between her two maids of honor ${ }^{194}$.

189 V. Nabokov, Ada or Ardor: A Family Chronicle..., s. 225.

190 Ibidem, s. 382.

191 Ibidem, s. 452.

192 В. В. Набоков, Приглашение на казнь.., s. 24.

193 V. Nabokov, Ada or Ardor: A Family Chronicle..., s. 237.

194 V. Nabokov, Lolita..., s. 52. 
- 'słodkie' odczucia Humberta związane były też z porannymi przyjemnościami uprawiania miłości z dziewczynką:

How sweet it was to bring that coffee to her, and then deny it until she had done her morning duty ${ }^{195}$.

- słodkie uczucie utraty:

Сладко мне было терять тебя. Ты ушла, угловато дернув стеклянную дверь. Но другая ты уходила иначе - распахнув бледные глаза под моими счастливыми поцелуями. Ничего нет слаще уходящей музыки ${ }^{196}$.

- 'sweet happiness' - nuta słodkiego szczęścia była dostrzegalna w informacjach z Terry przekazywanych Vanowi, choć w rzeczywistości w dużym stopniu było to oszustwem ${ }^{197}$.

- 'deep hot sweetness'198 - seksualne podniecenie Humberta pod wpływem dotyku ciała Lolity. Dalej w powieści 'sweet’ pojawia się też w opisie 'słodko skowyczącego' ${ }^{199}$ kontaktu fizycznego między mężczyzną o anormalnych skłonnościach i małą dziewczynką:

Ladies and gentlemen of the jury, the majority of sex offenders that hanker for some throbbing, sweet-moaning, physical but not necessarily coital, relation with a girl-child, are innocuous, inadequate, passive, timid strangers who merely ask the community to allow them to pursue their practically harmless, so-called aberrant behaviour...200

5) Określenia miejsc:

- Terra w Adzie:

Our enchanters, our demons, are noble iridescent creatures with translucent talons and mightily beating wings; but in the eighteen-sixties the New

195 Ibidem, s. 164-165.

196 В. В. Набоков, Звуки..., s. 36.

197 V. Nabokov, Ada or Ardor: A Family Chronicle..., s. 341.

198 V. Nabokov, Lolita..., s. 60.

199 V. Nabokov, Lolita, przeł. M. Kłobukowski..., s. 105.

200 V. Nabokov, Lolita..., s. 88. 
Believers urged one to imagine a sphere where our splendid friends had been utterly degraded, had become nothing but vicious monsters, disgusting devils, with the black scrota of carnivore and the fangs of serpents, revilers and tormentors of female souls; while on the opposite side of the cosmic lane a rainbow mist of angelic spirits, inhabitants of sweet Terra, restored all the stalest but still potent myths of old creeds, with rearrangement for melodeon of all the cacophonies of all the divinities and divines ever spawned in the marshes of this our sufficient world ${ }^{201}$.

- 'My land, sweet land' - wypowiedź Demona z sentymentalną nutą, na wzór angielskiego powiedzenia 'home, sweet home', pod wpływem wspomnień związanych z latami spędzonymi w posiadłości w Ardis ${ }^{202}$.

- Europa:

„Nobody strolled and laughed on the sidewalks as relaxing burghers would in sweet, mellow, rotting Europe" - Humbert o bezludnych ulicach jednego z mijanych w czasie samotnej podróży miast ${ }^{203}$.

6) Określenie słów:

W Adzie słodycz słowa skojarzona została z bogactwem i dążeniem do jego posiadania:

When I was your age I thought that the sweetest word in the language rhymes with 'billiard', and now I know I was right ${ }^{204}$.

7) Określenie sytuacji / wydarzeń:

- 'sweet banality' - 'słodki banał' określa relacje między Vanem i Cordulą, które w przeciwieństwie do jego kontaktów z Adą, nie miały znaczenia ${ }^{205}$.

201 V. Nabokov, Ada or Ardor: A Family Chronicle..., s. 21.

202 Ibidem, s. 238.

203 V. Nabokov, Lolita..., s. 281.

204 V. Nabokov, Ada or Ardor: A Family Chronicle..., s. 241.

205 Ibidem, s. 324. 
- 'wine-sweet event'206 - wydarzenie w niedzielny słoneczny poranek, gdy Humbert w szlafroku schodzi do salonu, w którym spotyka Lolitę. Tam wyrwał czasopismo z rąk Lo, zmuszając ją do kontaktu jej ciała z własnym, gdy próbowała mu odebrać swoją własność.

- 'sweetnesss of atonement' - Humbert, podejrzewając zdradę, uderzył Lolitę w twarz. Nasuwającym się później wyrzutom sumienia towarzyszyła 'słodycz pokuty' i zmysłowe pojednanie:

Lo looked up with a semi-smile of surprise and without a Word I delivered a tremendous back-hand cut that caught her smack on her hot hard little cheekbone. And then the remorse, the poignant sweetness of sobbing atonement, groveling love, the hopelessness of sensual reconciliation ${ }^{207}$.

- 'sweet sensation' - słodkie doznanie rozkoszy:

Very lightly he let his parched lips travel down her warm hair and hot nape. It was the sweetest, the strongest, the most mysterious sensation that the boy had ever experienced; nothing in his sordid venery of the past winter could duplicate that downy tenderness, that despair of desire ${ }^{208}$.

8) Inne określenia:

- słodkie usposobienie:

the sweet temper and lipid grace of Blanche 209 .

- 'słodka aura ulgi':

A sweet aura of intense relief made the candle rear its flame as old Azureus saw Krug spread the last page on the flat wooden arm of his cretonned armchair and unscrew the muzzle part of his pen, turning it into a cap ${ }^{210}$.

\footnotetext{
206 V. Nabokov, Lolita..., s. 57.

207 Ibidem, s. 227.

208 V. Nabokov, Ada or Ardor: A Family Chronicle..., s. 100.

209 Ibidem, s. 142.

210 V. Nabokov, Bend Sinister..., s. 40.
} 
- 'słodki uścisk’ podczas aktu seksualnego:

Things went better six minutes later, after Cheshire and Zographos were through; but only at the next mating party did Van really begin to enjoy her gentleness, her soft sweet grip and hearty joggle ${ }^{211}$.

- 'słodki powiew wolności':

И настолько сильна и сладка была эта волна свободы, что все показалось лучше, чем на самом деле... ${ }^{212}$

\section{Dotyk}

1) dotyk i słowo

- metafora synestezyjna obecna jest w refleksji dotyczącej rosyjskiego słowa измена, które zostało określone jako wężowate i wodnisto-jedwabiste:

The Russian term for any kind of betrayal, faithlessness, breach of trust, is the snaky, watered-silk word izmena which is based on the idea of change, shift, transformation. This derivation had never occurred to me in my constant thoughts about Iris, but now it struck me as the revelation of a bewitchment, of a nymph's turning into a whore - and this called for an immediate and vociferous protest $\mathrm{t}^{213}$.

2) dotyk i pora dnia:

Z trudnych do jednoznacznego określenia przyczyn, Nabokov przedstawia opis doznań dotykowych za pomocą ich porównania do zjawisk na niebie. Podczas próby dokonania aktu seksualnego przeszkodą okazały się drażniące jak rozgwieżdżone niebo, kłujące włosy kanapy: ,the shag of the couch was as tickly as the star-dusted

211 V. Nabokov, Ada or Ardor: A Family Chronicle..., s. 33.

212 В. В. Набоков, Приглашение на казнь.., s. 41.

213 V. Nabokov, Look at the Harlequins!, McGraw-Hill Book Company, New York 1974, s. 74. 
sky"214. Sygnałem zaś do zakończenia owych igraszek było ostrzegawcze wołanie drozda i światła pod osłoną szorstkiego świtu:

[...] it burst at the lip of the orchid, and a bluebird uttered a warning warble, and the lights were now stealing back under a rugged dawn, the firefly signals were circumscribing the reservoir, the dots of the carriage lamps became stars...215

\section{Temperatura}

1) temperatura życia:

a) 'zimne życie':

In passing, he touched a half-opened rose and was cheated of the sterile texture his fingertips had expected when cool life kissed them with pouting $\operatorname{lips}^{216}$.

b) 'gorące życie' Cyncynata:

При этом все в нем дышало тонкой, сонной, - но в сущности необыкновенно сильной, горячей и своебытной жизнью217.

2) temperatura uczuć / zachowania:

a) Teść chłodno żegnał się z Cyncynatem po widzeniu w więzieniu (próbował wcześniej załatwić z nim sprawy majątkowe córki):

Ну-с, не поминай лихом, - сказал тесть и с холодной учтивостью поцеловал Цинциннату руку, как того требовал обычай 218.

b) Pierre oskarża Cyncynata o to, że z 'okrutnym chłodem' odnosi się do Rodryga Iwanowicza:

214 V. Nabokov, Ada or Ardor: A Family Chronicle..., s. 121.

215 Ibidem.

216 Ibidem, s. 32.

217 В. В. Набоков, Приглашение на казнь..., s. 69.

218 Ibidem, s. 60. 
Вот мне и больно бывает смотреть, с какой жестокой холодностью, с каким надменным презрением вы отталкиваете Родрига Ивановича ${ }^{219}$;

c) 'zimno traktować kogoś': Charlotta Haze chłodno odnosiła się do córki:

Never had I thought that the rather ridiculous, though rather handsome Mrs. Haze, with her blind faith in the wisdom of her church and book club, her mannerisms of elocution, her harsh, cold, contemptuous attitude toward an adorable, downy-armed child of twelve, could turn into such a touching, helpless creature as soon as I laid my hands upon her...220

d) 'chłód ciszy / niezadowolenia' - opis relacji Humberta z żonami: najpierw Walerią, później Charlotą:

My habit of being silent when displeased, or more exactly, the cold and scaly quality of my displeased silence ${ }^{221}$;

e) chłód zdenerwowania (rozczarowania):

Он развернул литературный номер парижской «Газеты» и с холодком внезапного волнения увидел большой фельетон Христофора Мортуса, посвященный «Сообщению»222;

3) temperatura sposobu mówienia:

a) chłód: Humbert ozięble ('coldly') odpowiedział obsłudze w recepcji hotelu na informację, że rezerwacja pokoju przepadła z powodu ich zbyt późnego przyjazdu 223 ,

b) niezmiennie, z 'lodowatą precyzją' ('icy precision') Lolita wybierała Hamburgera zamiast Humburgera - jedzenie zamiast kontaktu z Humbertem ${ }^{224}$.

219 Ibidem, s. 64.

220 V. Nabokov, Lolita..., s. 76.

221 Ibidem, s. 89.

222 В. В. Набоков, Дар..., s. 150.

223 V. Nabokov, Lolita..., s. 118.

224 Ibidem, s. 166. 
4) temperatura spojrzenia:

chłodne spojrzenie Humberta (,raising a cold eye from book to clock in the positively lustry Beardsley College library" ${ }^{225}$ ) wyrażające znudzenie i zniecierpliwienie. Nieco dalej zaś chłodne spojrzenie ('cold gaze'226) Mony, koleżanki Lo.

5) temperatura (atmosfery) pomieszczenia:

We would put her in Lo's room. I intended to make a guestroomof that hole anyway. It's the coldest and meanest in the whole house ${ }^{227}$.

Charlotte Haze opisuje pokój Lolity jako ciemny w znaczeniu ‘nieprzyjemny, odpychający' i chce umieścić w nim służącą, którą zamierza zatrudnić.

\section{Podsumowanie}

Zestawienie w tabeli przedstawionych wyżej odmian konstrukcji metaforycznych, zilustrowanych przykładami z utworów Nabokova, pozwoli dostrzec pewne tendencje autora dotyczące projekcji cech doznań zmysłowych na wybrane pojęcia niezmysłowe (tab. 7).

225 Ibidem, s. 188-189.

226 Ibidem, s. 192.

227 Ibidem, s. 82. 
Tabela 7

Odmiany synestezyjnych metafor Nabokova

\begin{tabular}{|c|c|c|c|}
\hline $\begin{array}{c}\text { Rodzaj } \\
\text { doznania } \\
\text { zmysłowego }\end{array}$ & \multicolumn{2}{|c|}{ Pojęcie niezmysłowe } & Konstrukcja metaforyczna \\
\hline 1 & \multicolumn{2}{|r|}{2} & 3 \\
\hline \multirow{6}{*}{ barwa } & \multirow[b]{2}{*}{$\begin{array}{l}\text { dźwięki: } \\
\text { głos, śpiew }\end{array}$} & słowa & mroczne słowa \\
\hline & & $\begin{array}{l}\text { ptaki śpiewa- } \\
\text { jące w osło- } \\
\text { necznionym } \\
\text { lesie } \\
\end{array}$ & pstrokate głosy ptaków \\
\hline & powietrze & & $\begin{array}{l}\text { pomarańczowe powietrze (po zacho- } \\
\text { dzie słońca) } \\
\text { zielone powietrze } \\
\text { blade powietrze (o brzasku) } \\
\text { barwne powietrze (zachodu słońca) }\end{array}$ \\
\hline & \multicolumn{2}{|c|}{$\begin{array}{l}\text { dni, pory dnia, godziny, } \\
\text { czas }\end{array}$} & $\begin{array}{l}\text { niebieski dzień } \\
\text { ciemnoniebieski dzień } \\
\text { mleczny dzień } \\
\text { ciemny dzień } \\
\text { perłowy ranek } \\
\text { oślepiająco zielone poranki } \\
\text { bladoniebieskie popołudnie } \\
\text { morelowo-czarny wieczór } \\
\text { przezroczysto-granatowy wieczór } \\
\text { granatowy wieczór } \\
\text { jasna godzina } \\
\text { ciemna godzina } \\
\text { ciemny kres pauzy }\end{array}$ \\
\hline & \multicolumn{2}{|c|}{$\begin{array}{l}\text { dni, pory dnia, godziny, } \\
\text { czas }\end{array}$} & $\begin{array}{l}\text { ciemna przeszłość } \\
\text { czarny czas } \\
\text { szary czas } \\
\text { szmaragdowe życie }\end{array}$ \\
\hline & \multicolumn{2}{|c|}{$\begin{array}{l}\text { cechy charakteru, zacho- } \\
\text { wanie }\end{array}$} & $\begin{array}{l}\text { matowa chciwość } \\
\text { złota pieszczoszka } \\
\text { mroczne spojrzenie }\end{array}$ \\
\hline
\end{tabular}


Tab. 7 (cd.)

\begin{tabular}{|c|c|c|}
\hline 1 & 2 & 3 \\
\hline \multirow{4}{*}{ barwa } & myśli, poglądy, opinie & $\begin{array}{l}\text { mgliste wyobrażenie } \\
\text { sztucznie podkolorowane wspomnie- } \\
\text { nia } \\
\text { mroczne zakątki umysłu } \\
\text { mroczne wątpliwości } \\
\text { promyki nadziei } \\
\text { szare metody wychowawcze }\end{array}$ \\
\hline & $\begin{array}{l}\text { stan emocjonalny, nastrój, } \\
\text { uczucie }\end{array}$ & $\begin{array}{l}\text { czarny nastrój } \\
\text { złota powódź radości } \\
\text { niebieskie dąsy } \\
\text { różowa radość } \\
\text { blada niemoc } \\
\text { słoneczny spokój } \\
\text { złocisty spokój } \\
\text { bezbarwna nuda }\end{array}$ \\
\hline & czyny i wydarzenia & $\begin{array}{l}\text { „czarne działania” } \\
\text { ciemne insynuacje }\end{array}$ \\
\hline & znak graficzny & $\begin{array}{l}\text { szary znak zapytania } \\
\text { szmaragdowy znak restauracji }\end{array}$ \\
\hline dźwięk & uczucie & szum szczęścia \\
\hline \multirow{6}{*}{ smak } & uczucie & $\begin{array}{l}\text { słodka zemsta } \\
\text { słodkie uczucie utraty } \\
\text { słodkie uczucie } \\
\text { słodkie szczęście } \\
\text { słodka aura ulgi } \\
\text { słodki powiew wolności }\end{array}$ \\
\hline & ciało & smaczne ciało kobiety \\
\hline & słowa & $\begin{array}{l}\text { apetyczne słowa } \\
\text { najsłodsze słowo }\end{array}$ \\
\hline & dzień, czas & $\begin{array}{l}\text { smak teraźniejszości } \\
\text { słodki letni dzień }\end{array}$ \\
\hline & dzień, czas & $\begin{array}{l}\text { słodkie letnie noce } \\
\text { słodko mrowiący wiosenny półmrok } \\
\text { słodko drzemiący czas }\end{array}$ \\
\hline & wrażenia percepcyjne & $\begin{array}{l}\text { smakować doznania dotykowe } \\
\text { słodkie doznania }\end{array}$ \\
\hline
\end{tabular}




\begin{tabular}{|c|c|c|}
\hline 1 & 2 & 3 \\
\hline \multirow{4}{*}{ smak } & uczynki, cechy & $\begin{array}{l}\text { upojenie winem uczciwości } \\
\text { słodkie usposobienie } \\
\text { słodycz wzajemnych usług } \\
\text { smaczny grzech } \\
\text { słodycz pokuty }\end{array}$ \\
\hline & dźwięki, rytm & $\begin{array}{l}\text { słodki głos } \\
\text { słodki chichot } \\
\text { słodko-chlupiąca wilgoć } \\
\text { słodki rytm postukiwania } \\
\text { słodki zgiełk }\end{array}$ \\
\hline & miejsce & \begin{tabular}{|l|} 
słodka Terra \\
słodki kraj \\
słodka Europa
\end{tabular} \\
\hline & wydarzenie & winno-słodkie wydarzenie \\
\hline \multirow{2}{*}{ dotyk } & słowo & wodnisto-jedwabiste słowo \\
\hline & pora dnia & szorstki świt \\
\hline \multirow{5}{*}{ temperatura } & życie & $\begin{array}{l}\text { zimne życie } \\
\text { gorące życie }\end{array}$ \\
\hline & uczucia, zachowania & $\begin{array}{l}\text { chłodne pożegnanie } \\
\text { okrutny chłód } \\
\text { zimne traktowanie } \\
\text { chłód niezadowolenia } \\
\text { chłód zdenerwowania } \\
\end{array}$ \\
\hline & $\begin{array}{l}\text { sposób mówienia, wypo- } \\
\text { wiedzi }\end{array}$ & $\begin{array}{l}\text { oziębła odpowiedź } \\
\text { lodowata precyzja }\end{array}$ \\
\hline & spojrzenie & chłodne spojrzenie \\
\hline & pomieszczenie & zimny pokój \\
\hline
\end{tabular}

Źródło: opracowanie własne.

W przypadku pisarza-kolorysty nie budzi zdziwienia duża liczba (44 przykłady) doznań pochodzących ze sfery widzenia, przeniesionych na pojęcia związane z otaczającym światem materialnym oraz na pojęcia abstrakcyjne. Relatywnie dużą grupę stanowią też 
konstrukcje związane z wrażeniami smakowymi (30 przykładów) i nieco mniejszą - z odczuciami temperatury (11 przykładów). Niespodzianką jest natomiast fakt, że wśród metafor synestezyjnych nie znajdziemy w ogóle lub zaledwie jednostkowe przykłady konstrukcji, w których transfer „modalność zmysłowa $\rightarrow$ pojęcie niezmysłowe" dotyczy zmysłów zapachu (0 przykładów), dźwięku (1 przykład), dotyku (2 przykłady) lub bólu (0 przykładów). Co również warto podkreślić, wrażenia sensoryczne posłużyły Nabokovowi pomocą przede wszystkim przy opisie stanów emocjonalnych bohaterów, ich odczuć, myśli, poglądów i zachowań oraz przy opisie dni, ich pór i godzin, które korespondowały z przedstawionymi w tekście wydarzeniami, przeżyciami i uczuciami. 


\section{ZAKOŃCZENIE}

Synestezja Nabokova jest zjawiskiem bardzo szerokim w swojej objętości i niezwykle różnorodnym. Obejmuje zarówno skojarzenia łączące modalności zmysłowe, jak i konstrukcje utworzone na podstawie projekcji doznań zmysłowych na pojęcia niezwiązane z odczuciami sensualnymi, do których należy szeroko pojmowana ideostezja. Niewątpliwie stanowi cechę charakteryzującą styl i estetykę Nabokova; jest swoistym znakiem rozpoznawczym jego dzieł i elementem, który różni jego sposób kreacji literackiego świata od sposobu kreacji innych twórców.

W czasie badań prowadzonych przez doktor Aleksandrę Rogowską wśród studentów Akademii Muzycznej w Katowicach, na pytanie Czy synestezja pomaga, czy przeszkadza $w$ muzyce?, trzydziestu trzech synestetyków odpowiedziało twierdząco, a pozostałych sześć osób miało obojętny stosunek do swej zdolności. Synestezja pomaga badanym studentom m.in. w: kształtowaniu wyobraźni, nadaje sens zmysłowemu odczuciu muzyki, w komponowaniu, w interpretacji-gram to, co widze, w improwizacji - to bardzo twórcze, $w$ wyrażaniu nastroju danego utworu, w ksztattowaniu emocji, intensyfikacji emocji, nastroju i przeżycia muzyczne$g o^{1}$. Spostrzeżenia te można odnieść do wpływu synestezji na proces twórczy Nabokova. Zarówno synestezja, jak i metafora synestezyjna nie są związane jedynie ze słowami. Ich obecność w codziennym życiu determinuje sposób myślenia i działania. Dar synestezyjnego widzenia świata niewątpliwie pomagał więc pisarzowi

1 A. Rogowska, Czy synestetycy sq wśród nas?, „Modelowe Nauczanie” 2004, nr 7, s. 43. 
w kształtowaniu wyobraźni, tworzeniu dzieł literackich, wyrażaniu nastroju powieści lub opowiadania, wyrażaniu i intensyfikacji emocji towarzyszących bohaterom, a także w strategii włączenia czytelnika do udziału w przygotowanej dla niego grze.

W swoich opisach Nabokov naśladuje naturę ożywioną i nieożywioną, a przy tym uwzględnia grę światła i cienia, co sprawia niekiedy, że utworzone obrazy wprowadzają w błąd nasz zmysł wzroku, ukazując nieistniejące obiekty. Właśnie wprowadzanie w błąd było typową dla Nabokova strategią. Pisywał o tym w odniesieniu do świata motyli, m.in. we fragmencie Daru, w którym Fiodor Konstantynowicz wspomina wyprawy entomologiczne ze swoim ojcem:

Opowiadał o niebywałym, pełnym dowcipu artystycznym zmyśle mimikry, niedającej się wytłumaczyć walką o byt [...], nazbyt wyszukanej, jakby chodziło jedynie o zmylenie przypadkowych wrogów, pierzastych, łuskowatych i innych [...], jakby wymyślonej przez malarza-dowcipnisia tylko dla mądrych oczu człowieka (domysł, który mógłby daleko zaprowadzić ewolucjonistę obserwującego żywiące się motylami małpy); opowiadał o magicznych maskach mimikry; o olbrzymiej ćmie, która w stanie spoczynku przybiera kształt spoglądającej na was żmii; o pewnym tropikalnym, miernicowatym, ubarwionym ściśle na podobieństwo określonego rodzaju zorzaka, nieskonczenie od niego odległego w systemie natury, przy czym dla żartu, iluzja oranżowego podbrzusza, którym odznacza się jeden, formuje się u drugiego z oranżowych par dolnych skrzydeł; i o swoistym haremie słynnego afrykańskiego kawalera, którego samica fruwa w kilku mimicznych odmianach, ubarwieniem, kształtem, a nawet lotem naśladując motyle innych gatunków (rzekomo niejadalnych), stanowiących model dla mnóstwa naśladowców².

Czytelnik bardzo często jest wprowadzany w błąd, jednocześnie jednak otrzymuje od autora wskazówki, sprytnie ukryte w słowach bohaterów oraz synestezyjnych w swoim charakterze opisach. Odczytywanie tych znaków wymaga szczególnej koncentracji uwagi oraz wrażliwości. Bohater powieści Dar, przystępując

${ }^{2}$ V. Nabokov, Dar, przeł. E. Siemaszkiewicz, posł. L. Engelking, Warszawskie Wydawnictwo Literackie MUZA SA, Warszawa 2003, s. 141-142. 
do lektury własnego tomiku wierszy, wspomina o pracy przeciwnej do tej, której dokonywał, kiedy „błyskawicznie przebiegał myślą książkę. Teraz czytał jakby w sześcianie, piastując każdy wiersz, uniesiony i ze wszystkich owiewany (tak, czy ze wszystkich stron?) cudownym, miękkim wiejskim powietrzem, tak skłaniającym pod wieczór do snu"3. Podobnie rzecz się ma z utworami Nabokova, bez względu na ich długość i formę. Ich lektura (najlepiej niejednokrotna) to proces dokonujący się w umyśle czytelnika, a w jego rezultacie przestrzenna, wielowymiarowa recepcja świata fabuły. Zresztą również w Darze Nabokov wspomina słowami swego bohatera o uczeniu ludzi wielopłaszczyznowości myślenia ${ }^{4}$ oraz o „migotaniu blasków wielokształtnej myśli, gry podejmowanej przez myśl z samą sobą"s.

Vladimir Nabokov - mistrz słowa, mistrz kamuflażu, mistrz wyrazu artystycznego - z niezrównaną umiejętnością i talentem maluje przed czytelnikiem obrazy i pozwala mu odczuć to, co przeżywają i odczuwają bohaterowie jego książek. Podobnie jak dla Fiodora Konstantynowicza w Darze, nie istnieją dla niego myśli, których nie byłby w stanie wyrazić za pomocą słów. Refleksja bohatera powieści odnosi się zatem do samego pisarza:

Skoro istniało coś, co pragnął wyrazić tak naturalnie i niepowstrzymanie, jak naturalnie zwiększają swą pojemność płuca przy oddychaniu - musiały znaleźć się słowa będące odpowiednikami oddechu. Częste u poetów skargi na to, że ach, brak im słów, słowa są blade i martwe, słowa w żaden sposób nie zdołają oddać ich uczuć (nad czym rozwodzą się sześciostopowym chorejem), wydawały mu się równie bezmyślne jak głębokie przekonanie najstarszego mieszkańca górskiej wioski, że na tamtą oto górę nikt nigdy nie wszedł i nie wejdzie; tymczasem pewnego pięknego, chłodnego ranka pojawia się wysoki szczupły Anglik i pełen radosnej energii wspina się na szczyt ${ }^{6}$.

\footnotetext{
3 Ibidem, s. 17.

4 Ibidem, s. 206.

5 Ibidem, s. 207.

6 Ibidem, s. 195.
} 
O wyjątkowości swego daru Nabokov mówi też w Zaproszeniu na egzekucję ustami Cyncynata, który wyznaje:

Nie jestem zwyczajnym... ja jeden pośród was jestem żywy... Nie tylko moje oczy są inne i słuch, i smak, nie tylko węch jak u jelenia, a dotyk jak u nietoperza - co innego jest najważniejsze: dar połączenia tego wszystkiego w jednym punkcie ${ }^{7}$.

Trafność i precyzja w doborze słów ze szczególną siłą przemawiają bowiem w Nabokovowskich opisach wrażeń zmysłowych, odpowiadających często stanom emocjonalnym bohaterów. Dzięki wspomnianej wielowymiarowości i zdumiewającej zdolności łączenia doznań pochodzących od różnych modalności - zarówno na niskim sensorycznym poziomie, jak i na wyższym konceptualnym - czytelnik może nie tyle przeczytać o doświadczanych przez bohaterów wrażeniach, ile samemu je odczuć. Choć marzeniem Nabokova było, by przekształcić czytelnika w widza, jak pisze o tym w Rozpaczy ${ }^{8}$, czytelnik jego utworów staje się czymś więcej niż obserwatorem - jest uczestnikiem wydarzeń. Słyszy kolorowy szum przechylanych na wietrze kwiatów, widzi oczami wyobraźni ich barwy, czuje ich woń przypominającą zapach dzieciństwa i smak ulubionych wówczas potraw, jest w stanie poczuć pod palcami jedwabistą miękkość - dźwięki mają bowiem barwy, a barwy mają zapachy.

7 V. Nabokov, Zaproszenie na egzekucje, przeł. L. Engelking, Warszawskie Wydawnictwo Literackie MUZA SA, Warszawa 2014, s. 48.

8 V. Nabokov, Rozpacz, przeł. L. Engelking, Wydawnictwo ATEXT, Gdańsk 1993, s. 22. 


\section{UTWORY VLADIMIRA NABOKOVA, KTÓRE STANOWIĄ BAZĘ MATERIAŁOWĄ MONOGRAFII}

\section{Opowiadania}

Time and Ebb

La Veneziana

Бахман

Боги

Благость

Бритва

Венецианка

Весна в Фиальте

Возвращение Чорба

Говорят по-русски

Гроза

Драка

Дракон

Звонок

Звуки

Картофельный Эльф

Катастрофа

Красавица

Круг

Месть

Музыка

Наташа

Нежить

Обида

Облако, озеро, башня

Пассажир 
Пасхальный дождь

Пильграм

Письмо в Россию

Подлец

Порт

Путеводитель по Берлину

Рождественский рассказ

Рождество

Сказка

Слово

Случайность

Совершенство

Удар крыла

Ужас

Xваm

\section{Powieści}

Ada or Ardor: A Family Chronicle

Bend Sinister

Lolita

Look at the Harlequins!

The Real Life of Sebastian Knight

Волиебник

Дар

Другие берега

маменька

Отчаяние

Подвиг

Приглашение на казнь 


\section{WYKAZ ILUSTRACJI}

Ilustracja 1. Tarcza barw i dźwięków według Izaaka Newtona ......................... 17

Ilustracja 2. Klawiatura Skriabina ........................................................................ 19

Ilustracja 3. Skala barw i dźwięków Neila Harbissona ........................................ 23

Ilustracja 4. Ludwig van Beethoven, Dla Elizy. Przykład dzieła Neila Harbissona

Ilustracja 5. Igor Strawiński, Święto wiosny. Przykład dzieła Neila Harbissona

Ilustracja 6. Jane Mackay, Chopin - Piano Concerto №. 2 ……………………….. $\quad 60$

Ilustracja 7. Powiązania międzymodalne: test takete / baluba .............................. $\quad 150$

Ilustracja 8. Powiązania międzymodalne: test kiki / bouba .................................. 151

Ilustracja 9. Relacje między kolorem i dźwiękiem u niesynestetyków ............ 156

Ilustracja 10. Akronimiczne tęcze Nabokova …........................................................ 162

Ilustracja 11. Okładka pierwszego rosyjskiego wydania Lolity ........................... 163 



\section{WYKAZ TABEL}

Tabela 1. Odmiany synestezji i częstotliwość ich występowania ....................... 51

Tabela 2. Rodzaje międzysensorycznych doznań Vladimira Nabokova ........... 102

Tabela 3. Zestawienie liter o jednakowym lub zbliżonym brzmieniu ................ 117

Tabela 4. Zestawienie liter o jednakowym lub zbliżonym kształcie i odmien-

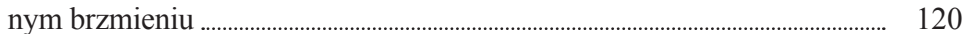

Tabela 5. Cechy synestezji silnej i słabej ............................................................... 154

Tabela 6. Akronimy-tęcze Nabokova ........................................................................... 161

Tabela 7. Odmiany synestezyjnych metafor Nabokova .......................................... 210 



\section{BIBLIOGRAFIA}

Alexandrov V. E. (ed.), The Garland Companion to Vladimir Nabokov, Routledge, New York 1995.

Berlin B., Kay P., Basic Color Terms. Their Universality and Evolution, Berkeley 1969, on-line: http://www.ucpress.edu/op.php?isbn=9780520076358 [dostęp: 30.06.2014].

Bodenstein J., ,, The Excitement of Verbal Adventure”: A Study of Vladimir Nabokov's English Prose, Heidelberg 1977.

Boyd B., Nabokov. Dwa oblicza, opracował i przełożył W. Sadkowski, Wydawnictwo Książkowe Twój Styl, Warszawa 2006.

Boyd B., Stalking Nabokov: selected essays, Columbia University Press, New York 2011.

Bucci W., Murphy S., Symbolic and Subsymbolic, The Referential Process, http:// www.thereferentialprocess.org/theory/symbolic-subsymbolic [dostęp: 5.06.2015].

Cancogni A., Nabokov and Chateaubriand, [w:] V. E. Alexandrov (ed.), The Garland Companion to Vladimir Nabokov, Routledge, New York 1995, s. 382-389.

Colours by numbers, „The Scotsman”, 30.01.2003, [w:] http:/www.scotsman. com/news/colours-by-numbers-1-543985 [dostęp: 4.02.2015].

Connolly J. W. (ed.), Nabokov's „Invitation to a Beheading”: A Critical Companion, Northwestern University Press, Evanston, Ill. 1997.

Cytowic R., The Man Who Tasted Shapes, Massachusetts Institute of Technology, Cambridge 2003.

Cytowic R., Synesthesia: A Union of the Senses, Massachusetts Institute of Technology, Cambridge 2002.

Cytowic R., Eagleman D., Wednesday Is Indigo Blue: Discovering the Brain of Synesthesia, Massachusetts Institute of Technology, Cambridge 2009.

Day S. A., A comparison of true-synesthete and pseudo-synesthete composers, [w:] Prometheus 2000 Conference Proceedings: On the Destiny of Light-Music at the Border of Centuries, red. B. Galeev, Kazań 2000, s. 77-80.

Day S. A., Some demographic and socio-cultural aspects of synesthesia, [w:] L. Robertson, N. Sagiv (eds), Synesthesia: Perspectives from Cognitive Neuroscience, OUP, Oxford 2005, s. 11-33. 
Day S. A., Synesthesia: A first person perspective, [w:] J. Simner, E. M. Hubbard (eds), Oxford Handbook of Synesthesia, OUP, Oxford 2013, s. 903-923.

Day S. A., Synaesthesia and synaesthetic metaphors, „Psyche”, July 1996, 2 (32), http://www.theassc.org/files/assc/2358.pdf [dostęp: 4.02.2015].

Day S. A., What synaesthesia is (and is not), [w:] P. McKevitt, S. Ó Nualláin, C. Mulvihill (eds), Language, Vision and Music, John Benjamins B.V., Amsterdam 2002, s. 171-180.

Duffy P. L., Simner J., Synaesthesia in fiction, „Cortex” 2010, vol. 46, Issue 2, s. 277 278, on-line: http://www.journals.elsevier.com/cortex [dostęp: 8.07.2013].

Engelking L., Chwyt metafizyczny. Vladimir Nabokov - estetyka z sankcja wyższej rzeczywistości, Wydawnictwo UŁ, Łódź 2011.

Engelking L., Posłowie, [w:] V. Nabokov, Dar, przeł. E. Siemaszkiewicz, Warszawskie Wydawnictwo Literackie MUZA SA, Warszawa 2003, s. 460-487.

Frye N., Baker S., Perkins G., The Harper Handbook to Literature, New York 1985.

Galeyev B., Vanechkina I., Was Scriabin a Synaesthete?, „Leonardo” 2001, vol. 34, No 4, s. 357-361, wersja on-line: The MIT Press: http://monoskop. org/images/f/fa/Galeyev,_B._M.\%3B_Vanechkina,_I._L._\%282001\%29_Was_Scriabin_a_Synesthete.pdf [dostęp: 25.01.2015].

Galton F., Visualised Numerals, „Nature”, 15.01.1880, s. 252-256, 494-495, wersja on-line: http://galton.org/essays/1880-1889/galton-1880-nature-visualised-numerals.pdf [dostęp: 3.02.2015].

Ginter A., Barwy w „Lolicie” Vladimira Nabokova, [w:] K. Wojtczuk (red.), „Conversatoria Linguistica”, rocznik II/2008, Wyd. AP, Siedlce 2009, s. 49-62, wersja on-line: http://www.ifp.ap.siedlce.pl/images/ifp_2012/Conversatoria_Linguisatica/CL_II/6_I_II.pdf.

Ginter A., Rola dźwięku w „Lolicie” Vladimira Nabokova, Ученые Записки Казанского Государственного Университета, т. 143, Казань 2002, s. 118-122.

Ginter A., Some aspects of synaesthesia and sound instrumentation in Nabokov's 'Lolita', [w:] M. Čarkić (red.), Styl, t. 1, Belgrad 2002, s. 273-283.

Ginter A., Sposoby oddania instrumentacji dźwiękowej w autorskich przekładach Vladimira Nabokova, [w:] K. Bajor, J. Wierzbiński (red.), Stowo w tekście, przekładzie i słowniku, Peter Lang, Europäischer Verlag der Wissenschaften, Beiträge zur Slavistik; Bd. 47, Frankfurt am Main 2002, s. 97-120.

Ginter A., Świat za stowami Vladimira Nabokova, Wydawnictwo UŁ, Łódź 2003. Grossenbacher P. G., Lovelace C. T., Mechanisms of synesthesia: cognitive and physiological constraints, „Trends in Cognitive Science” 2001, vol. 5, No 1, s. 36, http://www.daysyn.com/GrossenbacherLovelace2001.pdf [dostęp: 7.02.2015].

Hancock P., Synesthesia, alphabet books, and fridge magnets, [w:] J. Simner, E. M. Hubbard (eds), The Oxford Handbook of Synesthesia, Oxford 
University Press, Oxford 2013, ss. 83-100, on-line: http://philpapers.org/rec/ Hansab-2 [dostęp: 16.03.2014].

Harris J., Joanne Harris on the power of scent, „Daily Mail”, 7.08.2010, [w:] Mail Online, http://www.dailymail.co.uk/home/you/article-1299986/JoanneHarris-power-scent.html [dostęp: 4.02.2015].

Holabird J., Vladimir Nabokov: Alphabet in Color, with a foreword by B. Boyd, Gingko Press, Corte Madera, CA, 2005.

Holman C. H., A Handbook to Literature, Indianapolis 1976.

Ione A., Tyler Ch., Was Kandinsky a Synesthete?, „Journal of the History of the Neurosciences" 2003, vol. 12, No 2, s. 223-226.

James J., Muzyka sfer. O muzyce, nauce i naturalnym porzadku wszechświata, przeł. M. Godyń, Wyd. Znak, Kraków 1996.

Jewanski J., What is the color of the tone?, „Leonardo” 1999, vol. 32, No 3.

Johnson D. B., The Alpha and Omega of Nabokov's ,Invitation to a Beheading”, [w:] J. W. Connolly (ed.), Nabokov's ,Invitation to a Beheading”: A Critical Companion, Northwestern University Press, Evanston, Ill 1997, s. 119-140.

Jürgens U. M., Nikolić D., Ideaesthesia: conceptual processes assign similar colours to similar shapes, „Translational Neuroscience” 2012, vol. 3, No 1, s. $22-$ 27, http://www.daysyn.com/JuergensNikolic2012Ideaesthesia.pdf [dostęp: 8.02.2015].

Jürgens U. M., Nikolić D., Synaesthesia as an Ideasthesia-cognitive implications, [w:] J. Sinha, C. Söffing (eds), Synesthesia and Children - Learning and Creativity, Kassel University Press, Kassel 2014; http://www.dankonikolic.com/wp-content/uploads/2013/08/Ideasthesia_English.pdf [dostęp: 8.02.2015].

Kleparski G. A., Kierunki typologiczne w badaniach nad zmiana znaczeniowa wyrazów, „Bulletin de la Société Polonaise de Linguistique”, fasc. LV, 1999, s. 76-91, wersja on-line: http://www.mimuw.edu.pl/polszczyzna/PTJ/b/ b55_077-092.pdf [dostęp: 10.05.2015].

Köhler W., Gestalt Psychology, Liveright, New York 1929.

Kopaliński S., Stownik symboli, Oficyna Wydawnicza „Rytm”, Warszawa 2012.

Kubovy M., Yu M., Multistability, cross-modal binding and the additivity of conjoined grouping principles, „Philosophical Transactions of The Royal Society B" 2012, vol. 367, ss. 954-964, http://rstb.royalsocietypublishing. org/content/royptb/367/1591/954.full.pdf [dostęp: 3.06.2015].

Kuryłowicz B., ,,Jak purpurowy zapach róży...” Metafory synestezyjne w młodopolskich tekstach poetyckich, „Białostockie Archiwum Językowe” 2011, nr 11, s. 99-114.

Lakoff G., Johnson M., Metafory w naszym życiu, przeł. i napisał wstęp T. Krzeszowski, Wydawnictwo Aletheia, Warszawa 2010.

Leibnitz G. W., Nowe rozważania dotyczące rozumu ludzkiego, przeł. I. Dąmbska, wstęp L. Kołakowski, t. I i II, PWN, Warszawa 1955. 
Lipczak A., Czerwień gra między f a fis, wywiad z Neilem Harbissonem, „Gazeta Wyborcza", 25.04.2013, wersja on-line: http://wyborcza.pl/piatekekstra/1,132083,13804847, Czerwien_gra_miedzy_f_a_fis.html [dostęp: 12.11.2014].

Locke J., Rozważania dotyczące rozumu ludzkiego, przeł. B. Gawęcki, t. II, PWN, Warszawa 1955.

Maciaszek J., Znaczenie, prawda, przekonania. Problematyka znaczenia $w$ filozofii języka, Wydawnictwo Uniwersytetu Łódzkiego, Łódź 2008.

Marks L. E., On Colored-Hearing Synesthesia: Cross-Modal Translations of Sensory Dimensions, „Psychological Bulletin”, May 1975, vol. 82, No 3, s. 303-331.

Marks L. E., Synesthesia, Then and Now, „Intellectica” 2011, 1, 55, s. 47-80, wersja on-line: http://www.daysyn.com/Marks2011.pdf [dostęp: 21.01.2015].

Martin P., Synaesthesia, metaphor and right-brain functioning, „Egoist” 2006, wersja on-line: http://barneygrant.tripod.com/synaes.htm [dostęp: 8.07.2013].

Martino G., Marks L. E., Synesthesia: Strong and Weak, „Current Directions in Psychological Science", April 2001, vol. 10, No 2, s. 61-65, wersja online http://www.cogsci.ucsd.edu/ creel/COGS160/COGS160_files/MartinoMarks01.pdf [dostęp: 21.01.2015].

Meier B., Semantic representation of synaesthesia , Theoria et Historia Scientiarum” 2013, vol. 10, s. 125-134, wersja on-line: http://apcz.pl/czasopisma/index.php/ THS/article/view/ths-2013-0006/3524 [dostęp: 5.02.2015].

Meier B., Rothen N., Grapheme-color synaesthesia is associated with a distinct cognitive style, ,Frontiers in Psychology” 2013, vol. 4, artykuł nr 632, http:// www.apn.psy.unibe.ch/unibe/philhuman/psy/apn/content/e5638/e6102/ e147979/e380914/MeierRothen_FIF2013_ger.pdf [dostęp: 7.02.2015].

Mills C., Viguers M. L., Edelson S. K., Thomas A. T., Simon-Dack S. L., Innis J. A., The color of two alphabets for a multilingual synesthete, „Perception” 2002, vol. 31, s. 1371-1394; wersja on-line: https:/www.researchgate.net/ publication/10983904_The_color_of_two_alphabets_for_a_multilingual_ synesthete [dostęp: 5.02.2015].

Moritz W., The Dream of Color Music, and Machines That Made it Possible, „Animation World Magazine”, April 1997, Issue 2.1, http://www.awn.com/ mag/issue2.1/articles/moritz2.1.html [dostęp: 21.01.2015].

Morner K., Rausch R., NTC's Dictionary of Literary Terms, Lincolnwood, Ill., 1994.

Mroczko-Wąsowicz A., Nikolić D., Colored alphabets in bilingual synesthets, [w:] J. Simner, E. M. Hubbard (eds), The Oxford Handbook of Synesthesia, Oxford University Press, Oxford 2013, ss. 165-180, wersja on-line: http:// philpapers.org/rec/MROCAI [dostęp: 16.03.2014]. 
Nabokov V., Ada albo Żar. Kronika rodzinna, przeł. L. Engelking, Warszawskie Wydawnictwo Literackie MUZA SA, Warszawa 2009.

Nabokov V., Ada or Ardor: A Family Chronicle, McGraw-Hill Book Company, New York-Toronto 1969.

Nabokov V., Bend Sinister, Henry Holt and Company, New York 1947.

Nabokov V., Czarodziej, przeł. A. Kołyszko, Wydawnictwo Da Capo, Warszawa 1997.

Nabokov V., Czas i zmierzch, [w:] V. Nabokov, Kęs życia i inne opowiadania, t. II, przeł. L. Engelking i M. Kłobukowski, posł. L. Engelking, Warszawskie Wydawnictwo Literackie MUZA SA, Warszawa 2011, s. 543-553.

Nabokov V., Dar, przeł. E. Siemaszkiewicz, posł. L. Engelking, Warszawskie Wydawnictwo Literackie MUZA SA, Warszawa 2003.

Nabokov V., Kęs życia i inne opowiadania, t. II, przeł. L. Engelking i M. Kłobukowski, posł. L. Engelking, Warszawskie Wydawnictwo Literackie MUZA SA, Warszawa 2011.

Nabokov V., List, który nigdy nie dotart do Rosji i inne opowiadania, t. I, przeł. M. Kłobukowski i L. Engelking, Warszawskie Wydawnictwo Literackie MUZA SA, Warszawa 2007.

Nabokov V., Lolita, przeł. M. Kłobukowski, Wydawnictwo Da Capo, Warszawa 1997.

Nabokov V., Lolita, Penguin Books, London 1995.

Nabokov V., Look at the Harlequins!, McGraw-Hill Book Company, New York 1974.

Nabokov V., Mademoiselle O, [w:] V. Nabokov, Kęs życia i inne opowiadania, przeł. L. Engelking, Warszawskie Wydawnictwo Literackie MUZA SA., Warszawa 2011, s. 375-397.

Nabokov V., Mademoiselle O, [w:] V. Nabokov, The Stories of Vladimir Nabokov, Vintage Books, New York 1997, s. 480-492.

Nabokov V., Nabokov's Interview, BBC Television, 1962; wersja on-line: http:// www.kulichki.com/moshkow/NABOKOW/Inter02.txt [dostęp: 8.07.2013].

Nabokov V., Odczyt o poezji rosyjskiej, przeł. R. Stiller, „Literatura na Świecie” 1978, nr 8, ss. 138-163.

Nabokov V., The Original of Laura: (Dying Is Fun) A Novel In Fragments, Penguin Modern Classics, London 2009.

Nabokov V., Pamięci, przemów. Autobiografia raz jeszcze, przeł. A. Kołyszko, posł. L. Engelking, Warszawskie Wydawnictwo Literackie MUZA SA, Warszawa 2004.

Nabokov V., Patrz na te Arlekiny!, przeł. A. Kołyszko, posł. L. Engelking, Warszawskie Wydawnictwo Literackie MUZA SA, Warszawa 2005.

Nabokov V., Poems and Problems, McGraw-Hill Book Company, New York 1970. 
Nabokov V., The Real Life of Sebastian Knight, wersja on-line: http://www.rulit. me/books/the-real-life-of-sebastian-knight-read-152417-22.html [dostęp: 16.02.2015].

Nabokov V., Rozpacz, przeł. L. Engelking, Wyd. ATEXT, Gdańsk 1993.

Nabokov V., Speak, Memory: An Autobiography Revisited, Vintage International, Knopf Doubleday Publishing Group, New York, 2011, wersja on-line: http://www.rulit.me/books/speak-memory-an-autobiography-revisitedread-336809-16.html [dostęp: 13.02.2015].

Nabokov V., Splendor, przeł. A. Kołyszko, posł. L. Engelking, Warszawskie Wydawnictwo Literackie MUZA SA, Warszawa 2006.

Nabokov V., Strong Opinions, Vintage International, New York 1990, wersja on-line: http://royallib.com/read/nabokov_vladimir/Strong_opinions.html\#0 [dostęp: 3.01.2015].

Nabokov V., Times and Ebb, [w:] V. Nabokov, The Stories of Vladimir Nabokov, Vintage Books, New York 1997, s. 580-586.

Nabokov V., Wyktady o literaturze, przeł. Z. Batko, Warszawskie Wydawnictwo Literackie MUZA SA, Warszawa 2001.

Nabokov V., Z nieprawej strony, przeł. R. Śmietana, Wydawnictwo Literackie, Kraków 1995.

Nabokov V., Zaproszenie na egzekucję, przeł. L. Engelking, Warszawskie Wydawnictwo Literackie MUZA SA, Warszawa 2014.

Nabokov V., La Veneziana, [w:] V. Nabokov, List, który nigdy nie dotart do Rosji i inne opowiadania, t. I, przeł. M. Kłobukowski i L. Engelking, Warszawskie Wydawnictwo Literackie MUZA SA, Warszawa 2007, s. 145-182.

Narloch A., Цветообозначения в русском и польском языках. Структурно-семантический, терминологический и когнитивный аспекты, Wydawnictwo Naukowe UAM, Poznań 2013.

Newton I, Opticks or A Treatise of the Reflections, Refractions, Inflections, and Colours of Light, Dover Publication, Inc., New York 1952.

Nierobisz P., Interaktywne projekcje i wizualizacje (VJing) w kontekście filmowym, 2012, http://www.visuals.pl/interaktywneProjekcje.pdf [dostęp: 21.01.2015].

Nikolić D., Is synaesthesia actually ideaesthesia? An inquiry into the nature of the phenomenon, Proceedings of the Third International Congress on Synaesthesia, Science \& Art, Granada, Spain, April 26-29, 2009; http:// www.danko-nikolic.com/wp-content/uploads/2011/09/Synesthesia2009Nikolic-Ideaesthesia.pdf [dostęp: 8.02.2015].

Pitzer A., Ukryta historia Vladimira Nabokova, przeł. W. Górnaś, Warszawskie Wydawnictwo Literackie MUZA SA, Warszawa 2015.

Rader Ch., Tellegen A., A Comparison of Synesthetes and Nonsynesthetes, [w:] E. Klinger (ed.), Imagery, t. II, Concepts, Results and Applications, Plenum Press, New York 1981, s. 153-163. 
Ramachandran V. S., Hubbard E. M., Hearing colors, tasting shapes, „Scientific American" 2003, s. 52-59, http://cbc.ucsd.edu/pdf/SciAm_2003.pdf [dostęp: 7.02.2015].

Ramachandran V. S., Hubbard E. M., Psychophysical investigations into the neural basis of synaesthesia, „Proceedings of the Royal Society of London” 2001, B 268, s. 979-983; on-line: http://cbc.ucsd.edu/pdf/Synaesthesia\%20-\%20 P\%20Royal\%20Soc.pdf [dostęp: 5.02.2015].

Ramachandran V.S., Hubbard E.M., Synaesthesia - A Window Into Perception, Thought and Language, „Journal of Consciousness Studies”, vol. 8, No 12, 2001, s. 3-34; wersja on-line: http://cbc.ucsd.edu/pdf/Synaesthesia\%20-\%20 JCS.pdf [dostęp: 3.02.2015].

Rogowska A., Czy synestetycy sq wśród nas?, „Modelowe Nauczanie” 2004, nr 7, s. $29-49$.

Rogowska A., U źródet synestezji: podstawy fizjologiczne i funkcjonalne, „Przegląd Psychologiczny” 2002, t. 45, nr 2, 4, s. 465-474, wersja on-line: https:// www.kul.pl/files/714/media/4.45.2002.art.6.pdf [dostęp: 4.01.2015].

Rogowska A., Zwiazki synestezji z muzyka, ,Muzyka” 2002, nr 1, s. 85-95.

Sachs C., Muzyka w świecie starożytnym, przeł. Z. Chechlińska, PWM, Warszawa 1988.

Sadkowska A., Synteza sztuk we francuskim romantyzmie i symbolizmie, http:// biesiada.polon.uw.edu.pl/symbolizm.pdf [dostęp: 27.01.2015].

Schiff S., Vera Nabokova. Portret matzeństwa, przeł. W. M. Próchniewicz, Wydawnictwo Książkowe Twój Styl, Warszawa 2005.

Senderecka M., Synestezja - od psychofizjologicznych badań do filozoficznych implikacji, [w:] S. Wszołek, R. Janusz (red.), Wyzwania racjonalności, Wydawnictwo WAM, Kraków 2006, s. 259-278, wersja on-line: www.kognitywistyka.upjp2.edu.p1/resources/artykuly/sender1.pdf [dostęp: 20.08.2013].

Shapiro G., Setting his myriad faces in his text: Nabokov's authorial presence revisited, [w:] J. W. Connolly (ed.), Nabokov and his Fiction. New Perspectives, Cambridge University Press, Cambridge 1999, s. 15-35.

Shaw-Miller S., Synaesthesia, [w:] T. Shephard, A. Leonard (eds), The Routledge Companion to Music and Visual Culture, Routledge, New York 2014, s. 13-24.

Simner J., Defining synaesthesia, „British Journal of Psychology” 2012, vol. 103, s. 1-15, on-line http://www.daysyn.com/Simner2012.pdf [dostęp: 8.07.2013].

Simner J., Holenstein E., Ordinal Linguistic Personification as a Variant of Synesthesia, ,Journal of Cognitive Neuroscience” 2007, vol. 19 (4), s. 694703, wersja on-line: http://www.daysyn.com/SimnerandHolenstein2007. pdf [dostęp: 3.02.2015].

Simner J., Hubbard E. M. (eds), The Oxford Handbook of Synesthesia, Oxford University Press, Oxford 2013.

Simner J., Ward J., Lanz M., Jansari A., Noonan K., Glover L., Oakley D. A., Non-random associations of graphemes to colours in synaesthetic and 
non-synaesthetic population, „Cognitive Neuropsychology” 2005, 22 (8), Psychology Press Ltd., s. 1069-1085, on-line: http://www.daysyn.com/Simneretal2005.pdf [dostęp: 5.02.2015].

Smilek D., Dixon M. J., Cudahy C., Merikle P. M., Synaesthetic Photisms Influence Visual Perception, „Journal of Cognitive Neuroscience” [MIT] 2001, vol. 13, No 7, s. 930-936, wersja on-line: http://www.daysyn.com/Smileketal2001b. pdf [dostęp: 4.02.2015].

Stępień-Kutera K., Bieguny manieryzmu - muzyczność i retoryka, „Res Facta Nova" 2007, nr 9 (18), wersja on-line: http://www.resfactanova.pl/pliki/ archiwum/numer_18/RFN18\%20Stepien-Kutera\%20-\%20Bieguny\%20 manieryzmu.pdf [dostęp: 21.01.2015].

Szymczak M., Słownik języka polskiego, PWN, Warszawa 1983.

Tenberken S., My Path Leads to Tibet: the inspiring story of how one young blind woman brought hope to the blind children of Tibet, Arcade Publishing, New York 2003.

Ward J., Simner J., Lexical-gustatory synaesthesia: linguistic and conceptual factors, „Cognition” 2003, vol. 89, s. 237-261, http:/www.daysyn.com/ WardSimner2003.pdf [dostęp: 6.02.2015].

Witthoft N., Winawer J., Synesthetic colors determined by having colored refrigerator magnets in childhood, „Cortex” 2006, http://psych.nyu.edu/ winawerlab/Publications/papers/witthoft_winawer_cortex_2006.pdf [dostęp: 6.02.2015].

\section{Pozycje w języku rosyjskim}

Бойд Б., Владимир Набоков: русские годьл, Симпозиум, 2010, wersja on-line: http://royallib.com/read/boyd_brayan/vladimir_nabokov_russkie_godi. html\#307200 [dostęp: 12.02.2015].

Бурлака Д. К. (ред.), В. В. Набоков: pro et contra, Издательство Русского Христианского гуманитарного института, Санкт-Петербург 1997.

Громова Т. В. (ред.), Владимир Владимирович Набоков. Рассказы. Приглашение на казнь. Роман. Эссе, интервью, рецензии, „Книга”, Москва 1989.

Джонсон Д., Миры и антимиры Владимира Набокова, пер. Т. Стрелковой, Издательство Симпозиум, Санкт-Петербург 2011, on-line: http://royallib.com/book/dgonson_donald/miri_i_antimiri_vladimira_nabokova.html [dostęp: 3.01.2015].

Лукьяненко И. Н., Луна цзвета Ю: генитивные конструкции со значением цъета у В. Набокова, «Вестник Балтийского федерального университета им. И. Канта» 2006, № 8, s. 34-39. 
Медарич М., Владимир Набоков и роман ХХ столетия, [w:] Д. К. Бурлака (ред.), B. В. Набоков: pro et contra, Издательство Русского Христианского гуманитарного института, Санкт-Петербург 1997, s. 454-475.

Набоков В. В., Бахман, [w:] В. В. Набоков, Полное собрание рассказов, составление текста и примечания - А. Бабиков, Изд. «Азбука-Аттикус», Санкт-Петербург 2013, s. 170-179.

Набоков В. В., Благость, [w:] В. В. Набоков, Полное собрание рассказов, составление текста и примечания - А. Бабиков, Изд. «Азбука-Аттикус», Санкт-Петербург 2013, s. 79-84.

Набоков В. В., Боги, [w:] В. В. Набоков, Полное собрание рассказов, составление текста и примечания - А. Бабиков, Изд. «Азбука-Аттикус», Санкт-Петербург 2013, s. 37-44.

Набоков В. В., Бритва, [w:] В. В. Набоков, Полное собрание рассказов, составление текста и примечания - А. Бабиков, Изд. «Азбука-Аттикус», Санкт-Петербург 2013, s. 211-214.

Набоков В. В., Венеиианка, [w:] В. В. Набоков, Полное собрание рассказов, составление текста и примечания - А. Бабиков, Изд. «Азбука-Аттикус», Санкт-Петербург 2013, s. 144-170.

Набоков В. В., Весна в Фиальте, [w:] В. В. Набоков, Полное собрание рассказов, составление текста и примечания - А. Бабиков, Изд. «Азбука-Аттикус», Санкт-Петербург 2013, s. 421-438.

Набоков В. В., Весна в Фиальте, [w:] Т. В. Громова (ред.), Владимир Владимирович Набоков. Рассказы. Пригламение на казнь. Роман. Эссе, интервью, рещензии, „Книга”, Москва 1989.

Набоков В. В., Возвращение Чорба, [w:] В. В. Набоков, Полное собрание рассказов, составление текста и примечания - А. Бабиков, Изд. «Азбука-Аттикус», Санкт-Петербург 2013, s. 198-205.

Набоков В. В., Волиебник, Изд. Сипмозиум, 2000, wersja on-line: http://royallib.com/book/nabokov_vladimir/volshebnik.html [dostęp: 10.12.2014].

Набоков В. В., Говорят по-русски, [w:] В. В. Набоков, Полное собрание рассказов, составление текста и примечания - А. Бабиков, Изд. «Азбука-Аттикус», Санкт-Петербург 2013, s. 17-25.

Набоков В. В., Гроза, [w:] В. В. Набоков, Полное собрание рассказов, составление текста и примечания - А. Бабиков, Изд. «Азбука-Аттикус», Санкт-Петербург 2013, s. 130-133.

Набоков В. В., Дар, [w:] Владимир Набоков. Собрание сочинений в четырех томах, под ред. В. В. Ерофеева, т. 3, Издательство «Правда», Москва 1990, s. 3-330.

Набоков В. В., Драка, [w:] В. В. Набоков, Полное собрание рассказов, составление текста и примечания - А. Бабиков, Изд. «Азбука-Аттикус», Санкт-Петербург 2013, s. 193-198. 
Набоков В. В., Дракон, [w:] В. В. Набоков, Полное собрание рассказов, составление текста и примечания - А. Бабиков, Изд. «Азбука-Аттикус», Санкт-Петербург 2013, s. 179-184.

Набоков В. В., Другие берега, [w:] Владимир Набоков. Собрание сочинений в четырех томах, под ред. В. В. Ерофеева, т. 4, Издательство «Правда», Москва 1990, s. 133-302.

Набоков В. В., Звонок, [w:] В. В. Набоков, Полное собрание рассказов, составление текста и примечания - А. Бабиков, Изд. «Азбука-Аттикус», Санкт-Петербург 2013, s. 236-246.

Набоков В. В., Звуки, [w:] В. В. Набоков, Полное собрание рассказов, составление текста и примечания - А. Бабиков, Изд. «Азбука-Аттикус», Санкт-Петербург 2013, s. 25-37.

Набоков В. В., Картофельный Эльф, [w:] В. В. Набоков, Полное собрание рассказов, составление текста и примечания - А. Бабиков, Изд. «Азбука-Аттикус», Санкт-Петербург 2013, s. 98-118.

Набоков В. В., Катастрофа, [w:] В. В. Набоков, Полное собрание рассказов, составление текста и примечания - А. Бабиков, Изд. «Азбука-Аттикус», Санкт-Петербург 2013, s. 124-130.

Набоков В. В., Красавища, [w:] В. В. Набоков, Полное собрание рассказов, составление текста и примечания - А. Бабиков, Изд. «Азбука-Аттикус», Санкт-Петербург 2013, s. 401-405.

Набоков В. В., Круг, [w:] В. В. Набоков, Полное собрание рассказов, составление текста и примечания - А. Бабиков, Изд. «Азбука-Аттикус», Санкт-Петербург 2013, s. 380-389.

Набоков В. В., Маменька, [w:] Владимир Набоков. Собрание сочинений в четырех томах, под ред. В. В. Ерофеева, т. 1, Издательство «Правда», Москва 1990, s. 33-112.

Набоков В. В., Месть, [w:] В. В. Набоков, Полное собрание рассказов, составление текста и примечания - А. Бабиков, Изд. «Азбука-Аттикус», Санкт-Петербург 2013, s. 72-79.

Набоков В. В., Музыка, [w:] В. В. Набоков, Полное собрание рассказов, составление текста и примечания - А. Бабиков, Изд. «Азбука-Аттикус», Санкт-Петербург 2013, s. 339-344.

Набоков В. В., Наташа, [w:] В. В. Набоков, Полное собрание рассказов, составление текста и примечания - А. Бабиков, Изд. «Азбука-Аттикус», Санкт-Петербург 2013, s. 133-144.

Набоков В. В., Нежить, [w:] В. В. Набоков, Полное собрание рассказов, составление текста и примечания - А. Бабиков, Изд. «Азбука-Аттикус», Санкт-Петербург 2013, s. 47-49.

Набоков В. В., Обида, [w:] В. В. Набоков, Полное собрание рассказов, составление текста и примечания - А. Бабиков, Изд. «Азбука-Аттикус», Санкт-Петербург 2013, s. 287-295. 
Набоков В. В., Облако, озеро, башня, [w:] В. В. Набоков, Полное собрание рассказов, составление текста и примечания - А. Бабиков, Изд. «Азбука-Аттикус», Санкт-Петербург 2013, s. 438-446.

Набоков В. В., Отчаяние, [w:] Владимир Набоков. Собрание сочинений в чеmырех томах, под ред. В. В. Ерофеева, т. 3, Издательство «Правда», Москва 1990, s. 333-462.

Набоков В. В., Пассажир, [w:] В. В. Набоков, Полное собрание рассказов, составление текста и примечания - А. Бабиков, Изд. «Азбука-Аттикус», Санкт-Петербург 2013, s. 231-236.

Набоков В. В., Пасхальный дождь, [w:] В. В. Набоков, Полное собрание рассказов, составление текста и примечания - А. Бабиков, Изд. «Азбука-Аттикус», Санкт-Петербург 2013, s. 118-124.

Набоков В. В., Пильграм, [w:] В. В. Набоков, Полное собрание рассказов, составление текста и примечания - А. Бабиков, Изд. «Азбука-Аттикус», Санкт-Петербург 2013, s. 274- 287.

Набоков В. В., Письмо в Россию, [w:] В. В. Набоков, Полное собрание рассказов, составление текста и примечания - А. Бабиков, Изд. «Азбука-Аттикус», Санкт-Петербург 2013, s. 189-193.

Набоков В. В., Подвиг, [w:] Владимир Набоков. Собрание сочинений в четырех томах, под ред. В. В. Ерофеева, т. 2, Издательство «Правда», Москва 1990, s. 155-296.

Набоков В. В., Подлеи, [w:] В. В. Набоков, Полное собрание рассказов, составление текста и примечания - А. Бабиков, Изд. «Азбука-Аттикус», Санкт-Петербург 2013, s. 246-269.

Набоков В. В., Полное собрание рассказов, составление текста и примечания - А. Бабиков, Изд. «Азбука-Аттикус», Санкт-Петербург 2013.

Набоков В. В., Порт, [w:] В. В. Набоков, Полное собрание рассказов, составление текста и примечания - А. Бабиков, Изд. «Азбука-Аттикус», Санкт-Петербург 2013, s. 84-90.

Набоков В. В., Приглашение на казнь, [w:] Владимир Набоков. Собрание сочинений в четырех томах, под ред. В. В. Ерофеева, т. 4, Издательство «Правда», Москва 1990, s. 3-130.

Набоков В. В., Путеводитель по Берлину, [w:] В. В. Набоков, Полное собрание рассказов, составление текста и примечания - А. Бабиков, Изд. «Азбука-Аттикус», Санкт-Петербург 2013, s. 206-211.

Набоков В. В., Рождественский рассказ, [w:] В. В. Набоков, Полное собрание рассказов, составление текста и примечания - А. Бабиков, Изд. «Азбука-Аттикус», Санкт-Петербург 2013, s. 269-274.

Набоков В. В., Рождество, [w:] В. В. Набоков, Полное собрание рассказов, составление текста и примечания - А. Бабиков, Изд. «Азбука-Аттикус», Санкт-Петербург 2013, s. 184-189. 
Набоков В. В., Сказка, [w:] В. В. Набоков, Полное собрание рассказов, составление текста и примечания - А. Бабиков, Изд. «Азбука-Аттикус», Санкт-Петербург 2013, s. 214-225.

Набоков В. В., Слово, [w:] В. В. Набоков, Полное собрание рассказов, составление текста и примечания - А. Бабиков, Изд. «Азбука-Аттикус», Санкт-Петербург 2013, s. 50-53.

Набоков В. В., Случайность, [w:] В. В. Набоков, Полное собрание рассказов, составление текста и примечания - А. Бабиков, Изд. «Азбука-Аттикус», Санкт-Петербург 2013, s. 90-98.

Набоков В. В., Совериенство, [w:] В. В. Набоков, Полное собрание рассказов, составление текста и примечания - А. Бабиков, Изд. «Азбука-Аттикус», Санкт-Петербург 2013, s. 352-362.

Набоков В. В., Удар крыла, [w:] В. В. Набоков, Полное собрание рассказов, составление текста и примечания - А. Бабиков, Изд. «Азбука-Аттикус», Санкт-Петербург 2013, s. 53-72.

Набоков В. В., Ужас, [w:] В. В. Набоков, Полное собрание рассказов, составление текста и примечания - А. Бабиков, Изд. «Азбука-Аттикус», Санкт-Петербург 2013, s. 225-231.

Набоков В. В., Хват, [w:] В. В. Набоков, Полное собрание рассказов, составление текста и примечания - А. Бабиков, Изд. «Азбука-Аттикус», Санкт-Петербург 2013, s. 344-352.

Носик Б., Мир и дар Набокова, Изд. „Пенаты”, Москва 1995.

Ожегов С. И., Словарь русского языка, под ред. Н. Ю. Шведовой, «Русский язык», Москва 1987.

\section{Materiały audiowizualne, biogramy, biografie, prywatne strony internetowe}

Art and Technology, „International Herald Tribune”, November 27, 2013, wersja on-line: http://www.iht.com/2013/11/27/art-and-technology/ [dostęp: 12.11.2014].

Bouba/Kik effect, http://en.wikipedia.org/wiki/Bouba/kiki_effect [dostęp: 5.02.2015].

Collopy F., Three Centuries of Color Scales, https://modernpost.wordpress. com/2009/06/17/musical-musings-colour-music/ [dostęp: 25.01.2015].

Day S. A., Famous Synesthets, http://www.daysyn.com/Synesthete-composers-and-musicians.html\#anchor_147 [dostęp: 2.02.2015]; http://www.daysyn.com/ Other-Synesthetes.html\#anchor_82 [dostęp: 3.02.2015]. 
Giuseppe Arcimboldo. Biografia, http://www.arcimboldo.art.pl/old/index1.htm [dostęp: 20.01.2015].

Mackay J., Sounding Art, http://www.soundingart.com/ [dostęp: 3.02.2015].

Neil Harbisson - człowiek, który styszy kolory, http://vumag.pl/wywiady/neil-harbisson-czlowiek-ktory-slyszy-kolory,64143.html [dostęp: 27.10.2014].

Neil Harbisson, Wikipedia: http://en.wikipedia.org/wiki/Neil_Harbisson [dostęp: 12.11.2014].

Weber B., Eugène Delacroix, Narodowy Instytut Fryderyka Chopina, 2010, http:// pl.chopin.nifc.pl/chopin/persons/detail/id/2692 [dostęp: 27.01.2015]. 



\section{VLADIMIR NABOKOV AND HIS SYNAESTHETIC WORLD}

\section{(Summary)}

The monographic study Vladimir Nabokov and His Synaesthetic World aims at presenting the wide range of synaesthesias and synaesthetic constructions in Vladimir Nabokov's prose. It consists of four chapters considering the phenomenon observed in selected short stories and novels of this famous Russian and American writer. The list of Nabokov's works analysed for the present book includes 53 positions both in Russian and English languages.

The first chapter, entitled Synaesthesia, provides an outline of the history of research on the phenomenon of synaesthesia. What is interesting, the research has been intensified considerably for the past twenty five years and the growing number of studies has exposed the condition to a wider range of specialists in this field. The discussion among the researchers revealed different approaches to the problem of defining synaesthesia. The key areas, recognised as divisive, refer to the claims that synaesthesia is a merging of the senses, which gives rise to consistent synaesthetic associations over time, with synaesthetic associations that are spatially extended ${ }^{1}$. Julia Simner considers taking into account the biological characteristic of the phenomenon as the definitional criterion. Consequently, she describes synaesthesia as an inherited

1 J. Simner, Defining synaesthesia, „British Journal of Psychology” 2012, vol. 103, on-line: http://www.daysyn.com/Simner2012.pdf, s. 2. 
condition which gives rise to neurodevelopmental differences leading to excess association between otherwise separate regions ${ }^{2}$. More specified definition has been suggested by Danko Nikolić who treats synaesthesia as a phenomenon in which a mental activation of a certain concept or idea is associated consistently with a certain perception-like experience ${ }^{3}$. Having taken into consideration different points of view on the nature of synaesthesia, the Nabokov's synaesthetic constructions have been divided into two groups: synaesthesias and ideasthesias. The first one discusses the phenomena in which stimulation of one sensory pathway leads to involuntary experiences in another sensory pathway. The second group includes those examples in which activations of concepts evoke experiences of sensory nature.

Additionally, the first chapter considers qualities and characteristics of synaesthesia. It also introduces concepts and proposals connected with the mechanism and sources of synaesthesia and synaesthetic associations. There have been recalled the pioneering works of neurologists: Richard Cytowic, Vilayanur S. Ramachandran, David Eagleman, Stephanie Simon-Dack; psychologists: Lawrence Edward Marks, Jullia Simner, Edward Hubbard, Carol Mills, Simon Baron-Cohen, Danko Nikolic, Jamie Ward, Uta Maria Jürgens, Ashok Jansari, a linguist and anthropologist Sean A. Day (president of the American Synesthesia Association), and the art historian - Simon Shaw-Miller.

The last part of the chapter portrays famous people with the gift of synaesthesia - painters, composers, musicians, scientists - and the way in which they tried (or try) to express their unique perceptions in their works. The list of well-known synaesthetes includes György Ligeti, Leonard Bernstein, Nikolay Rimsky-

2 Ibidem, s. 9.

3 D. Nikolić, Is synaesthesia actually ideaesthesia? An inquiry into the nature of the phenomenon, Proceedings of the Third International Congress on Synaesthesia, Science \& Art, Granada, Spain, April 26-29, 2009; http://www.danko-nikolic.com/ wp-content/uploads/2011/09/Synesthesia2009-Nikolic-Ideaesthesia.pdf [dostęp: 8.02.2015]. 
-Korsakov, Olivier Messiaen, Franz Liszt, Amy Beach, Duke Ellington, Tori Amos, Grace Barrett, Jim Hall, Kaitlyn Hova, Billy Joel and his daughter Alexa Ray Joel, Elvin Jones, Vincent van Gogh, Menthe Wells, Marcia Smilack, Joan Mitchell, Rosy Long, Vassily Kandinsky, Jane Mackay, Charles Baudelaire, Theodore Hoffman, Ellen Thornetcroft Fowler, Julie Myerson, Orhan Pamuk, Jane Yardley, Vladimir Nabokov, Arthur Rimbaud, Joanne Harris, Jane Yardley, Richard Feynman, Eugen Bleuler, Geoffrey V. Chester, Antoine Thomson d'Abbadie.

The next three chapters investigate the case of Nabokov's synaesthesia. The second chapter, entitled Synaesthesia in Nabokov's prose, analyses those synaesthetic associations in which both inducer (trigger) and concurrent (experience) belong to perceptual domains. In Nabokov's prose there have been observed numerous variants of synaesthesias that involve the so-called minor or lower senses of sight, sound, smell, taste, touch, temperature and pain. The most frequent perceptual experiences are those triggered by sounds such as the human voice, nature sounds or silence. These generate concurrents in the visual domain, touch modality and the domains of temperature and pain. Among the other types of Nabokov's cross-modal linkages between senses we can find the experiences triggered by colours (colour - synaesthetic tastes, colour - synaesthetic sounds, colour - synaesthetic touch, colour - synaesthetic temperature), smell (coloured smell, smell - synaesthetic touch, smell - synaesthetic taste, smell - synaesthetic temperature), temperature (temperature - synaesthetic taste, temperature - synaesthetic touch), pain (coloured pain), taste (coloured taste), touch (coloured touch). It is worth mentioning here that in Nabokov's texts we can also find examples of multiple synaesthesias such as smell of a sound temperature or hearing of touch coloured smell.

As it has been already said, synaesthesia is usually described as a perceptual phenomenon that creates a merging of senses. Therefore, academic research is focused mainly on its sensory 
characteristics. As it has been observed, however, this approach dominates despite the works that prove that a significant number of synaesthetic variants are triggered by linguistic units (e.g. words in their written or spoken forms). Such conceptual influences are considered in the third chapter of the monographic study, entitled Ideasthesia. One of the most common variants of ideasthesia is the triggering of colours by letters or numerals, known as grapheme - colour synaesthesia, which was experienced by Vladimir Nabokov. With unusual precision he described in his autobiography the colours he associated with each letter of the alphabet - both Russian and English. These experiences made it possible for him to create synaesthetic images in his texts. The significant majority of them refers to the names of protagonists of his works which can be illustrated by the coloured tones of the names of Tamara in Speak, Memory, Mary in Mary, Zina in The Gift, Ada in Ada or Ardor: A Family Chronicle. The analysed examples may suggest that in Nabokov's experience ideasthesia is triggered particularly by proper names although this could derive from his emotional state (or the emotional state of the protagonist).

There are several ideasthetic constructions in Nabokov's masterpieces thatcan be classified as ordinal linguistic personifications. In scientific literature this phenomenon is recognised as involuntary and automatic tendency to attribute animate-like qualities such as personality or gender to sequential linguistic units (e.g., letters, numerals, days, months) ${ }^{4}$. The examples found in writings of Nabokov entitle us to assume that he experienced this type of ideasthesia with reference to numerals and days.

The last chapter is devoted to synaesthetic metaphors in Nabokov's oeuvre. Numerous constructions of the analysed material show that although in some cases a perceptual mode is

4 J. Simner, E. Holenstein, Ordinal Linguistic Personification as a Variant of Synesthesia, „Journal of Cognitive Neuroscience” 2007, vol. 19 (4), s. 694-703, wersja on-line: http://www.daysyn.com/SimnerandHolenstein2007.pdf [dostęp: 3.02.2015]. 
initially specified, the imagery is linguistically related in terms belonging to one or more differing perceptual modes ${ }^{5}$. Contrary to the neurodevelopmental synaesthesia, meanings of synaesthetic metaphors are generated through semantic processes.

Nabokov's metaphoric expressions has been divided into two groups: cross-modal sensory metaphors and metaphors in which perceptual experiences are associated with non-perceptual aspects. The former group contains metaphors that resemble synaesthesias (e.g., deep crimson softness, orange heat) while the latter presents the common tendency to describe things in terms of sensory experiences (e.g., dim rays of hope, appetizing long words). Interestingly, interpretation of cross-modal sensory metaphors is determined by the context.

As an example of synaesthetic metaphor it has been also presented the relationship of Nabokov's audition colorée to his mirroring Russian and English rainbows. In two language versions of his memoirs, Russian (Drugie berega) and English (Speak, Memory), the writer classified his synaesthetic perceptions of letters as rainbow systems corresponding to his Russian and English alphabets respectively, for which he prepared acronyms: ВЕЁПСКЗ (B is red, E orange etc.) and KZSPYGV. As it has been discovered by D. Borton Johnson, Nabokov's rainbow acronyms, like the double rainbows in nature, represent the mirror images of two rainbows, the primary and the secondary. It is believed that in this metaphor the Russian rainbow represents Nabokov's primary literary creation while the English one - his secondary.

The monographic study shows the surprising world of Vladimir Nabokov's synaesthesia. Although he is known as a synaesthete who could hear in colour, his synaesthetic experiences were triggered not only by a range of senses but also by some linguistic entities and symbols such as phonemes, words, numerals. The analyses has revealed some linguistic and psychological mechanisms

${ }^{5}$ Compare: S. A. Day, Synaesthesia and synaesthetic metaphors, „Psyche”, July 1996, 2 (32), http://www.theassc.org/files/assc/2358.pdf [dostęp: 4.02.2015]. 
of Nabokov's synaesthesia. The recent findings from cognitive psychology and neural sciences have shed considerable light on the nature of synaesthesia and made it possible to explain some of the processes related to the phenomena experienced by Nabokov. There are however some aspects, such as interaction between two types of Nabokov's synaesthesia (e.g., chromesthesia and ordinal linguistic personification), that need additional investigation. 


\section{INDEKS OSÓB}

W indeksie uwzględniono nazwiska występujące zarówno w tekście, jak $\mathrm{i}$ adnotacjach. Nazwiska zapisane w monografii grażdanką poddano transkrypcji, w nawiasie przywołując wersję oryginalną. W indeksie pominięto nazwisko Władimira Nabokowa (Vladimira Nabokova).

A

Alexandrov Vladimir E. 198,225

Amos Tori 59, 241

Appel Alfred, Jr 12

Arcimboldo Giuseppe 145, 236

B

Babikow Andrey (Бабиков Андрей) 26,226

Baker Sheridan 26, 226

Baron-Cohen Simon 9, 41, 48, 240

Barrett Grace 59, 241

Batko Zbigniew 65, 230

Baudelaire Charles 61, 241

Beethoven Ludwig van 22, 24, 49, 64, 221

Beach Amy 59, 241

Berlin Brent 50, 225

Bernstein Leonard 58, 240

Bleuler Eugen 62, 241

Błok Aleksandr 126

Bodenstein Jürgen 10, 94, 225

Boyd Brian 11, 12, 76, 225, 227

Bucci Wilma 151, 225

Burłaka Dmitrij (Бурлака Дмитрий

Кириллович) 68,232

Burstall Christopher 77
C

Cancogni Annapaola 198, 225

Castel Louis Bertrand 18, 19

Chechlińska Zofia 15, 231

Chester Geoffrey V. 62, 241

Chopin Fryderyk 49, 60, 146, 221, 237

Collopy Fred 156, 236

Connolly Julian W. 114, 225, 227, 231

Cudahy Cera 34, 232

Cummings, nauczyciel 71

Cytowic Richard 9, 40-42, 148, 225, 240

Czernyszewski Nikołaj Gawriłowicz $12,64,126,127$

D

d'Abbadie Antoine Thomson 62, 241

Davino Ricardo 23

Day Sean 9, 20, 32, 42, 43, 50-53, $58,59,62,155,181,182,225$, 226, 236, 240, 243

Dąmbska Izydora 16, 227

Delacroix Eugène 146, 237 
Dixon Mike J. 34, 127, 232

Dobużyński Mstisław 71

Dolinin Aleksandr 95

Duffy Patricia Lynne 125, 226

Duval Smith Peter 77

E

Eagleman David 9, 29, 225, 240

Edelson Shari K. 30, 228

Ellington Duke 59, 241

Engelking Leszek $12,63,65,67,68$, $75,95,111,127-129,134,165$, $169,170,216,218,226,229,230$

\section{F}

Feynman Richard 62, 241

Field Andrew 133

Fowler Ellen Thornetcroft $\quad 61,241$

Frye Northrop 26, 226,

G

Galeyev Bulat 20, 226

Galton Francis 20, 226

Gawęcki Bolesław 16, 228

Ghil Renè 147

Ginter Anna 1, 124, 226, 247

Glover Louise $\quad 44,50,157,231$

Godyń Mieczysław 15, 227

Gogh Vincent van 59, 241

Górnaś Wojciech 130, 230

Graun Carl Heinrich 73

Gromowa T. W. (Громова Т. В.) 232, 233

Grossenbacher Peter 53, 226

H

Hall Jim 59, 188, 241

Hancock Peter 36-39, 123, 226

Harbisson Neil 21-25, 221, 228, 237
Harris Joanne $\quad 61,227,241$

Harrison John 41

Hoffman Theodore 61, 241

Holabird Jean 11, 227

Holenstein Emma 55, 56, 231, 242

Holman C. Hugh 26, 227

Hova Kaitlyn 59, 241

Hubbard Edward 9, 28, 32-34, 36, $38,40,42,57,123,124,151$, $152,226,228,231,240$

Hughes Robert 139

I

Innis Joanne A. 30, 228

Ione Amy 59, 60, 227

\section{J}

James Jamie 15, 165, 227

Jansari Ashok 9, 44, 50, 157, 231, 240

Janusz Robert 15, 151, 231

Jaremicz, nauczyciel 71

Jerofiejew Wiktor (Ерофеев Виктор Владимирович) 71, 81, 87, 90, $94,112,126,137,159,169,175$, 233-235, 246

Jewanski Jörg $\quad$ 15, 227

Joel Alexa Ray 59, 241

Joel Billy 59, 241

Johnson Donald Barton 11, 109, 114, $133,139,140,160-164,170$, 227, 243

Johnson Mark 227

Jones Elvin 59, 241

Jürgens Uta Maria 9, 10, 30, 53, 54,

94, 227, 240

K

Kandinsky Vassily 59, 60, 227, 241

Karlinsky Simon 12 
Kay Paul 50, 225

Kircher Athanasius 18

Kleparski Grzegorz A. 180, 227

Klinger Eric 153,230

Kłobukowski Michał 68, 131, 137, 191, 195, 204, 229, 230

Kołakowski Leszek 16, 227

Kołyszko Anna 67, 68, 111, 170, 229, 230

Kopaliński Stanisław 132, 227

Korff Ferdynand von 73

Köhler Wolfgang 150, 227

Krzeszowski Tomasz 227

Kubovy Michael 150, 227

Kuryłowicz Beata 98, 227

$\mathbf{L}$

Lakoff George 227

Lanz Monika 44, 50, 157, 232

Lehmann Karl 158

Leibnitz Gottfried Wilhelm 16, 227

Leonard Anne 15, 20, 58, 152, 226, 227, 231, 240

Ligeti György $\quad 57,58,152,240$

Lipczak Aleksandra 22, 228

Liszt Franz 59, 241

Locke John 15, 16, 228

Long Rosy 59, 241

Lovelace Christopher 53, 226

$\mathbf{L}$

Łukjanienko Irina (Лукьяненко Ирина Николаевна) 129, 232

Łuria Aleksander $\quad 46,47$

M

Maciaszek Janusz 228

Mackay Jane $\quad 60,221,236,241$

Marks Lawrence Edward 9, 152, $153,155,228,240$
Martin Patrick 86, 91, 92, 101, 167, 196

Martino Gail 153, 155, 228

McKevitt Paul 20, 226

Meier Beat 45, 46, 57, 228

Merikle Philip M. 34, 232

Messiaen Olivier 58, 241

Miauton Cécile 130

Miedaricz Magdalena (Медарич Магдалена) $\quad 68,232$

Mills Carol 9, 30, 228, 240

Mitchell Joan 59, 241

Montandon Adam 22

Moritz William 18, 228

Morner Kathleen 228

Mozart Wolfgang Amadeus 22, 49

Mroczko-Wąsowicz Aleksandra 38, $42,124,228$

Mulvihill Conn 20, 226

Murphy Sean 151, 225

Myerson Julie 61, 241

\section{$\mathbf{N}$}

Nabokow Nikołaj Dmitriewicz 73

Nabokow Dmitrij 73

Nabokow Jelena Iwanowna 72

Narloch Andrzej 230

Newman Charles 12

Newton Izaak 16-18, 22, 157, 221, 230

Nierobisz Piotr 19, 146, 230

Nikolić Danko 9, 30, 31, 38, 42, 53, $54,124,227,228,230,240$

Noonan Krist 44, 50, 157, 231

Nosik B. (Носик Б.) 236

O

Ó Nualláin Sean 20, 226

Oakley David A. 44, 50, 157, 231

Ozhegov Sergey (Ожегов Сергей Иванович) 88, 236 


\section{$\mathbf{P}$}

Pamuk Orhan 61, 241

Perkins George 26, 226

Pitzer Andrea 130, 230

Puszkin Aleksander 126

\section{$\mathbf{R}$}

Rader Charles 153, 230

Ramachandran Vilayanur S. 9, 28, $32-34,40,57,151,152,231,240$

Rausch Ralph 228

Rimbaud Arthur 58, 61, 147, 241

Rimskij-Korsakow Mikołaj 58

Robertson Lynn 32, 52, 155, 225

Robinson, guwernantka 70

Rogowska Aleksandra 26, 34-36, $39,46-49,56,145,147-149$, $154,155,158,215,231$

Rothen Nicolas 46, 57, 228

\section{S}

Sachs Curt 15, 231

Sachs Georg Tobias Ludwig 20

Sadkowska Agata 146, 147, 231

Sadkowski Wacław 76, 225

Sagiv Noam 32, 52, 155, 225

Schiff Stacy 12, 231

Scholes Percy Alfred 49

Senderecka Magdalena 15, 16, 26, $33,34,44,47,48,150,152,181$, 231

Shapiro Gavriel 11, 231

Shaw-Miller Simon 9, 58, 152, 231, 240

Shephard Tim 58, 152, 231

Shvedova Natalia (Шведова Наталия Юльевна) 88, 236

Siemaszkiewicz Eugenia 12, 63, 169, 216, 226, 229

Simner Julia 9, 25, 27-29, 31, 36, $38,39,42,44,50,55,56,123-$
$125,157,158,226,228,231$, $232,239,240,242$

Simon-Dack Stephanie 9, 30, 228, 240

Sinha Jasmin 54, 227

Skriabin Aleksander Nikołajewicz 19, 20, 146, 221

Smilack Marcia 59, 241

Smilek Daniel 34, 232

Söffing Christine 54, 227

Stępień-Kutera Kamila 18, 145, 232

Strawiński Igor 24, 221

Szereszewski Salomon $\quad 46,47$

Szulgina Walentyna Jewgienijewna 134

Szymczak Mieczysław 26, 232

Ś

Śmietana Rafał 230

T

Telemann Georg Philipp 18

Tellegen Auke 153, 230

Tenberken Sabriye 43, 232

Thomas Amanda T. 30, 228

Toffler Alvin 138

Tołstoj Lew 173

Tyler Christopher

$\mathbf{U}$

Ullmann Stephen $\quad 181,182$

V

Vanechkina Irina 20, 226

Viguers Meredith L. 30, 228

W

Wagner Ryszard 60

Ward Hilda 130 
Ward Jamie 9, 39, 44, 50, 130, 157, Winower Jonathan 37

$158,231,232,240$

Ważyk Adam 61

Weber Bożena 146, 237

Wellek Albert 59, 66, 108, 158, 241

Witthoft Nathan 37, 38, 124, 232

Wszołek Stanisław 15, 151, 231

Wells Menthe 59, 66, 108, 158, 241

Y

Williams Joseph $\quad 180,182$

Yardley Jane $\quad 55,61,62,241$

Yu Minhong 150, 227 



\section{OD REDAKCJI}

Anna Ginter - językoznawca, absolwentka filologii rosyjskiej, polskiej i angielskiej Uniwersytetu Łódzkiego. Od lat swoje zainteresowania badawcze koncentruje głównie wokół twórczości Vladimira Nabokova. Obiektem rozważań w licznych pracach uczyniła mistrzostwo słowa tego rosyjskiego i amerykańskiego pisarza. Rezultaty swych badań opublikowała między innymi w monografii zatytułowanej Świat za słowami Vladimira Nabokova. Zabawy słowne i ich przekład (2003, Wydawnictwo Uniwersytetu Łódzkiego). Drugim jej obszarem zainteresowań naukowych są psycholingwistyka, lingwistyka kognitywna i neurolingwistyka, ze zwróceniem szczególnej uwagi na metaforyczne i synestezyjne postrzeganie świata. 